\title{
Hydrologic Response and Erosion Modeling of Geomorphic Landform Reclamation in Mountainous Terrain
}

\author{
Alison E. Sears
}

Follow this and additional works at: https://researchrepository.wvu.edu/etd

\section{Recommended Citation}

Sears, Alison E., "Hydrologic Response and Erosion Modeling of Geomorphic Landform Reclamation in Mountainous Terrain" (2015). Graduate Theses, Dissertations, and Problem Reports. 6596.

https://researchrepository.wvu.edu/etd/6596

This Dissertation is protected by copyright and/or related rights. It has been brought to you by the The Research Repository @ WVU with permission from the rights-holder(s). You are free to use this Dissertation in any way that is permitted by the copyright and related rights legislation that applies to your use. For other uses you must obtain permission from the rights-holder(s) directly, unless additional rights are indicated by a Creative Commons license in the record and/ or on the work itself. This Dissertation has been accepted for inclusion in WVU Graduate Theses, Dissertations, and Problem Reports collection by an authorized administrator of The Research Repository @ WVU.

For more information, please contact researchrepository@mail.wvu.edu. 
Hydrologic Response and Erosion Modeling of Geomorphic Landform Reclamation in Mountainous Terrain

Alison E. Sears, EIT, MSMinE

\begin{abstract}
Dissertation submitted
to the Benjamin M. Statler College of Engineering and Mineral Resources at West Virginia University

in partial fulfillment of the requirements for the degree of

Doctor of Philosophy in

Civil and Environmental Engineering
\end{abstract}

Leslie Hopkinson, Ph.D., Co-Chair

John Quaranta, P.E., Ph.D., Co-Chair

Hema Siriwardane, Ph.D.

Vladislav Kecojevic, Ph.D.

Brijes Mishra, Ph.D.

Department of Civil and Environmental Engineering

Morgantown, West Virginia

2015

Keywords: Surface Mining, Reclamation, Geomorphic Landform Design, HSPF, RUSLE Copyright 2015 Alison E. Sears 


\title{
Abstract \\ Hydrologic Response and Erosion Modeling of Geomorphic Landform Reclamation in Central Appalachia
}

\begin{abstract}
Alison Sears
Surface mining and valley-fill practices often lead to environmental impacts including headwater stream loss, increased flooding risk, and degraded downstream water quality. Geomorphic landform design (GLD) is an innovative reclamation technique proposed to lessen the impacts associated with surface mining and valley-fill activities. GLD incorporates mature landform shapes and created stream channels on site, imitating the function of the undisturbed landscape. The purpose of this research was to model GLDs in mountainous terrain and evaluate the hydrologic response and erosion potential of GLD in surface mining application. Computer modeling of valley-fill designs using geomorphic landform principles of a study site in southern West Virginia was performed. Four enhanced GLDs were created for application on new and previously constructed valley fills: 1) regional data GLD for new valley fill, 2) retrofit GLD for existing conventional valley fill, 3) regional data GLD enhanced with bench pond retention structures, and 4) regional data GLD enhanced with valley pond retention structures. Soil erosion was evaluated using the Revised Universal Soil Loss Equation (RUSLE) for the regional data GLD, conventional valley fill, and the undisturbed site during different stages of the reclamation process. Soil loss rates were highest (conventional: 123.2 $\mathrm{t} \mathrm{ha}^{-1} \mathrm{yr}^{-1}$; GLD: $204.3 \mathrm{t}$ $\mathrm{ha}^{-1} \mathrm{yr}^{-1}$ ) during the post-mining, pre-vegetation condition along the stream channels and steep slopes (slope $>50 \%$ ). Erosion rates were lowest for the post-reclamation, long term condition (conventional: $35.6 \mathrm{t} \mathrm{ha}^{-1} \mathrm{yr}^{-1}$; GLD: $41.8 \mathrm{t} \mathrm{ha}^{-1} \mathrm{yr}^{-1}$ ) along the ridges. Model predictions of soil erosion rates and spatial distributions illustrated areas of increased erosion potential for future minimization and reclamation method/management practices improvement. Hydrologic response modeling was performed for a watershed in southern West Virginia disturbed by surface mining and valley-fill activities to predict impacts on stream flows at the landscape scale. Incorporation of GLD reclamation methods did not result in substantial changes in current (2011-2020) or future (2041-2050) stream flowrates ( $\leq 3.3 \%$ difference) or stormflow volumes $(\leq 2.1 \%$ difference). The differences in flows and volumes could be used for mitigation plans in watersheds disturbed by surface mining and valley-fill activities.
\end{abstract}




\author{
Dedication \\ To Cooper Allen Sears, our lil' man \\ You are kind. \\ You are smart. \\ You are important. \\ Your family loves you more than everything.
}




\section{Acknowledgements}

The author would like to thank all of the people who committed their time and effort to the success of this research and her success in return. Special thanks go to the people that provided particular support and guidance including Dr. Leslie Hopkinson and Dr. John Quaranta for serving as my co-advisors, Dr. Vladislav Kecojevic, Dr. Hema Siriwardane, and Dr. Brijes Mishra for serving as a committee member. Without the knowledge and supervision of these individuals, this research would not have been successful.

In addition to her colleagues, the author would like to extend her gratitude to the Departments of Civil and Mining Engineering for their support and the United States Geological Survey for the funding of the research discussed throughout this dissertation.

The author would also like to thank her family and friends for their continued support and confidence in my education endeavors. Her husband has encouraged her and loved her unconditionally through her stress, tears, and smiles. She am so grateful for him allowing her to be his wife. She would also like to thank her Mom, who stayed by her side during my 45 weeks in the hospital, worries about her (and everyone/everything else), and continually makes her laugh. During her time at WVU, her life changed dramatically by the loss of some incredibly important and influential men in her life: Casey Allen Sears, Danny Sears, Dr. Christopher Bise, and Dr. Wahab "Doc" Khair. She was truly blessed to have them in her life. Despite these devastating losses, her family was blessed with a little man that brings them unbounding love and joy. They love him unconditionally and will always be there for him. She would also like to thank her Lord and Savior who brought her through the roughest times in her life and continues to guide her. 


\section{Table of Contents}

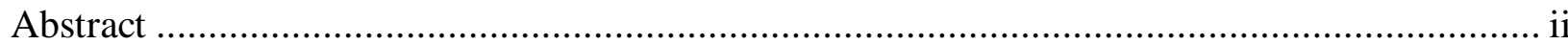

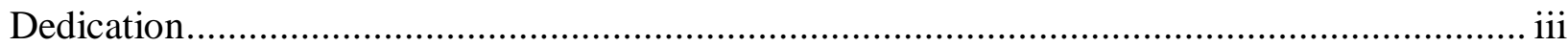

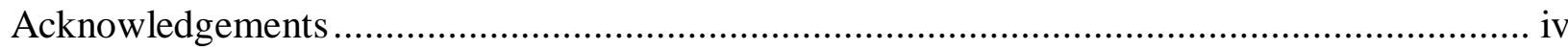

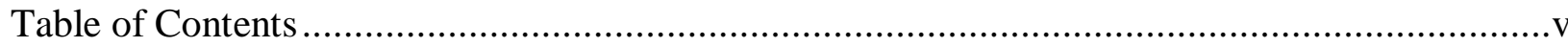

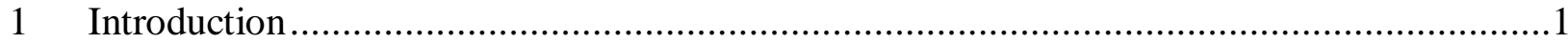

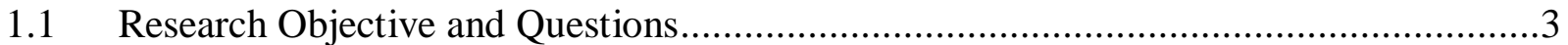

2 Literature Review ..........................................................................................

2.1 Valley-Fill Designs using Geomorphic Landform Principles .................................5

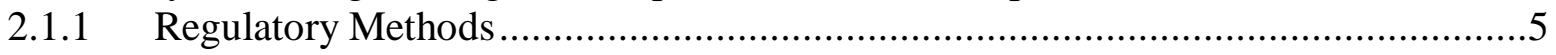

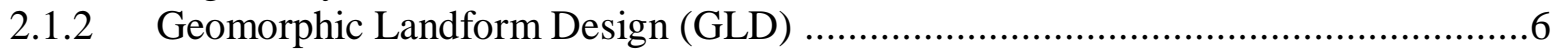

2.1.3 Reference Watershed Stream Channel Design ............................................6

2.1.4 Implementation Challenges .................................................................... 7

2.1.5 Geomorphic Landform Design (GLD) for West Virginia Site ............................

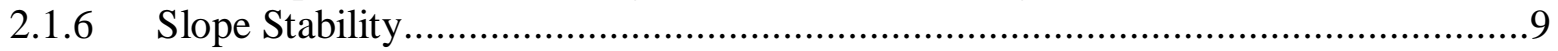

2.1.7 Stream Mitigation on Mine Sites in Appalachia ...........................................10

2.1.8 Stream Channel Bed Design on Valley Fills ..................................................11

2.1.9 Constructed Stream Channels on Reclaimed Surface Coal Mines ........................11

2.1.10 Stream Bed Design Materials ..................................................................... 12

2.2 Soil Erosion Estimation using Revised Universal Soil Loss Equation (RUSLE) and

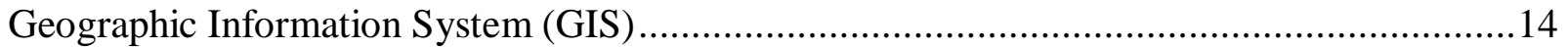

2.2.1 RUSLE and GIS ............................................................................. 14

2.2.2 RUSLE Factors Controlling Erosion of Mine Soils ....................................15

2.2.3 Modeled Hydrology and Erosion on Valley Fills (Geomorphic and Traditional) ..15

2.2.4 Soil Erosion Mapping Using RUSLE and GIS ..........................................16

2.2.5 Average Sediment Yield of Reclaimed Mine Spoil.......................................... 17

2.3 Hydrologic Response of Valley-Fill Designs at the Landscape Scale.........................18

2.3.1 Hydrologic Impacts of Land Use Alteration ............................................. 18

2.3.2 Surface Runoff, Stormflow Response, and Flow Path Impacts ..........................18

2.3.3 Flood Response Effects Modeled with HSPF ...................................................19

2.3.4 HSPF Calibration Parameter Examples for West Virginia .................................20

2.3.5 Future Hydrologic Research Needs ..............................................................21

3 Valley-Fill Designs using Geomorphic Landform Principles .......................................22

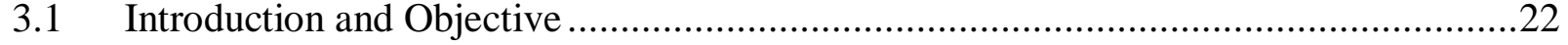

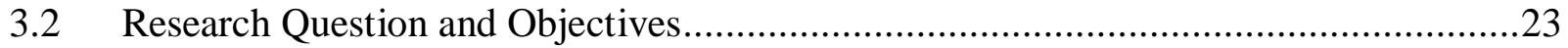

3.3 Background: Valley-Fill Design using Geomorphic Landform Principles..................23

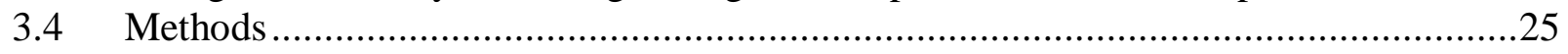

3.4.1 Study Site Description ...........................................................................25

3.4.2 Regional Data Geomorphic Landform Design ........................................ 27

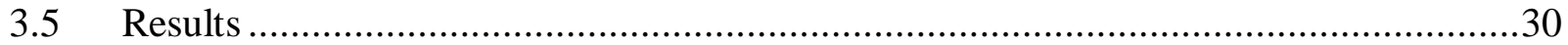

3.5.1 Regional Data Geomorphic Landform Design ............................................30

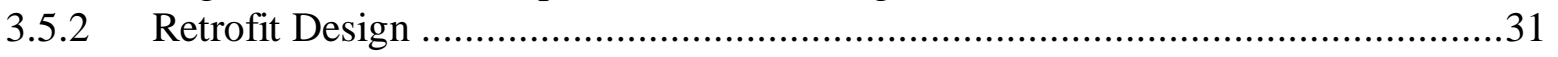

3.5.3 Regional Data GLD with Bench Ponds .........................................................34

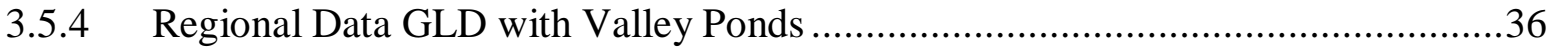

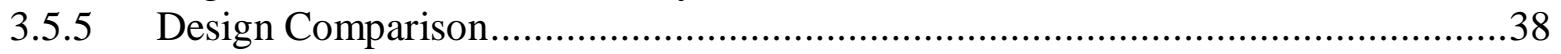


3.6 Discussion.

4 Soil Erosion Estimation using Revised Universal Soil Loss Equation (RUSLE) and

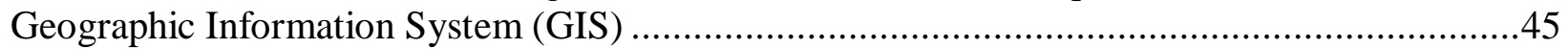

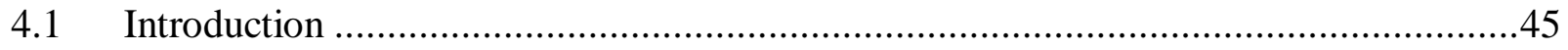

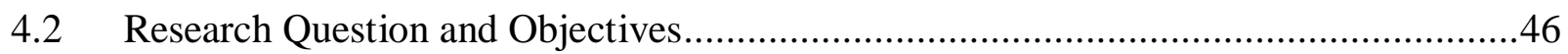

4.3 Background: Sediment Load using Revised Universal Soil Loss Equation (RUSLE) in a

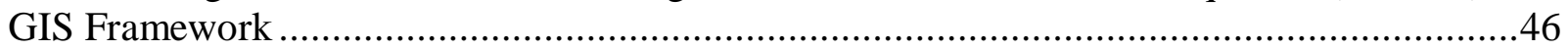

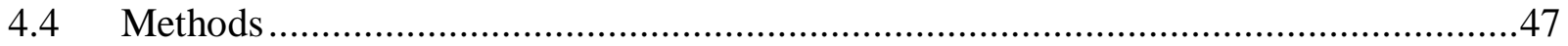

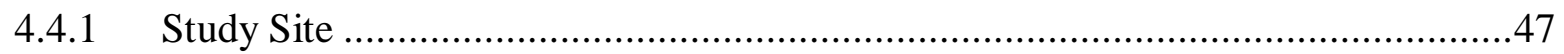

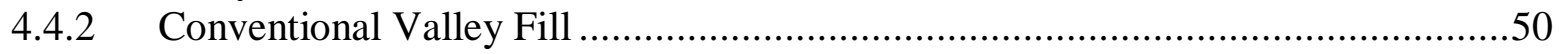

4.4.3 Geomorphic Landform Design (GLD) Valley Fill .............................................50

4.4.4 RUSLE Factor Determination Methods.........................................................50

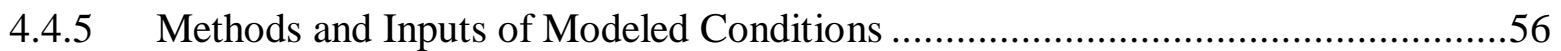

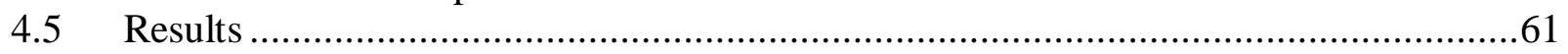

4.5.1 Undisturbed, Pre-Mining Condition Results .....................................................6

4.5.2 Conventional Valley Fill Post-Mining, Pre-Vegetation Condition Results ............662

4.5.3 Conventional Valley Fill Post-Reclamation, Long Term Condition Results ..........63

4.5.4 Undisturbed and Conventional Valley Fill Comparison ........................................64

4.5.5 GLD Post-Mining, Pre-Vegetation Condition Results .........................................67

4.5.6 GLD Post-Reclamation, Long Term Condition Results ......................................66

4.5.7 Undisturbed and GLD Valley Fill Comparison................................................69

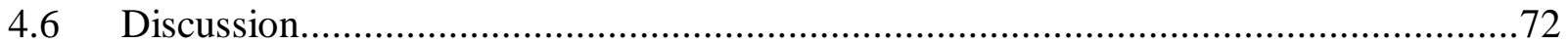

5 Hydrologic Response of Valley-Fill Designs at the Landscape Scale ................................77

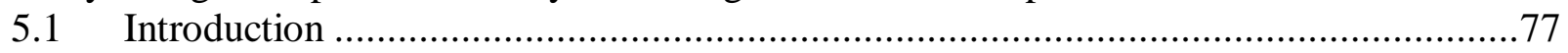

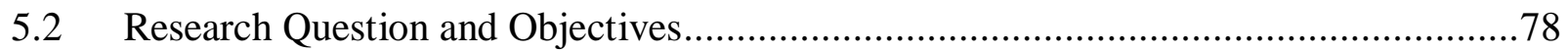

5.3 Background: Hydrologic Simulation Program-FORTRAN .........................................78

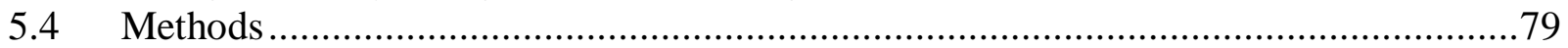

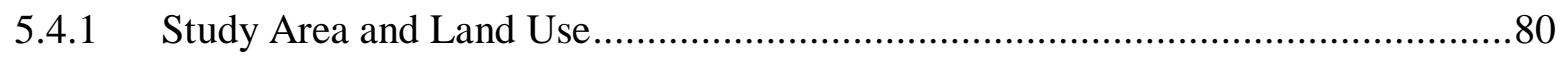

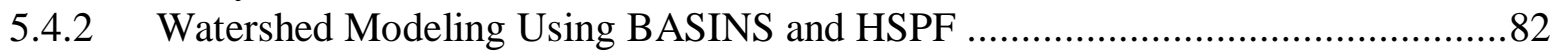

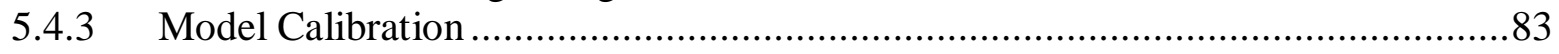

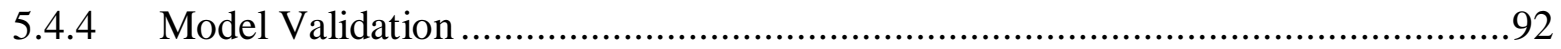

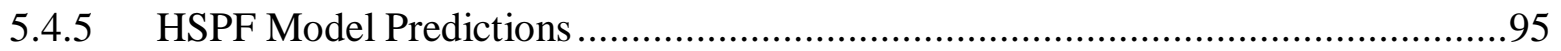

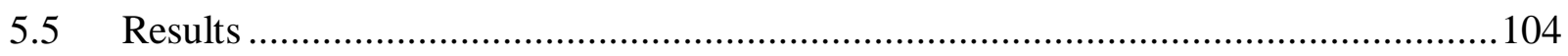

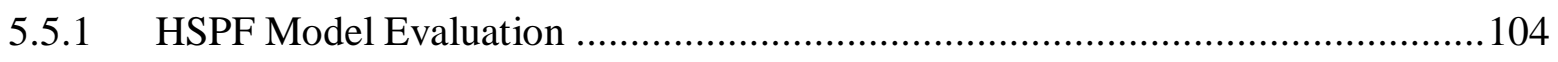

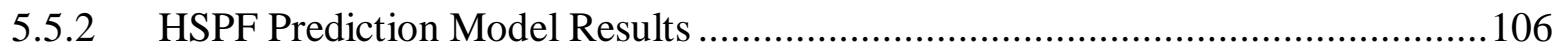

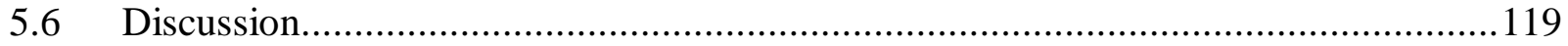

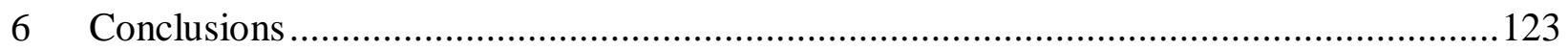

6.1 Valley-Fill Designs using Geomorphic Landform Principles ....................................123

6.2 Sediment Load using Revised Universal Soil Loss Equation (RUSLE) ......................124

6.3 Hydrologic Response of Valley-Fill Designs at the Landscape Scale ..........................125

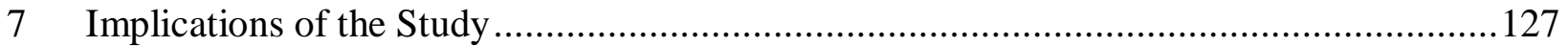

Proposed Contributions to the Body of Knowledge ...........................................................127

8 Limitations of Study and Future Research Recommendations .........................................128

8.1 Valley-Fill Designs using Geomorphic Landform Principles ......................................128

8.2 Sediment Load using Revised Universal Soil Loss Equation (RUSLE) .....................128

8.3 Hydrologic Response of Valley-Fill Designs at the Landscape Scale ..........................128 


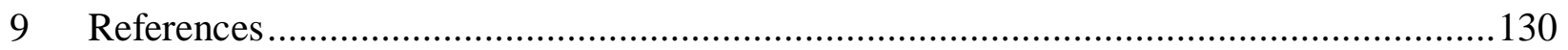

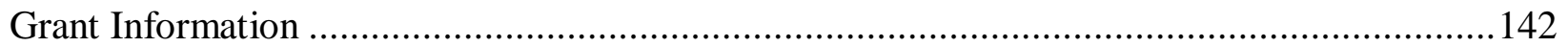

Appendix A: HSPF land use/land cover areas within each subwatershed .............................143

Appendix B: HSPF Calibration Parameters ................................................................... 144

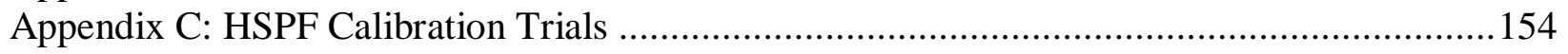




\section{Table of Figures}

Figure 3.1. Geomorphic landform design of experimental watershed and surrounding area in Logan County, WV, created using default design inputs....

Figure 3.2. Original topography of experimental watershed and surrounding area in Logan County, WV

Figure 3.3. Land use/land cover of experimental watershed and surrounding area in Logan County, WV....

Figure 3.4. Geomorphic landform design of experimental watershed in Logan County, WV, created using regional data design inputs

Figure 3.5. Retrofit design of experimental watershed in Logan County, WV, created with geomorphic landform design on conventional valley-fill crest (1.5 m contours for design watersheds; $15.2 \mathrm{~m}$ contours surrounding area)

Figure 3.6. Close-up of section 1 of retrofit design of experimental watershed in Logan County,

WV showing drainage pattern and topography ....

Figure 3.7. Geomorphic landform design with bench ponds of experimental watershed and surrounding area in Logan County, WV, created using regional design inputs (15.2 m contours for watershed; $0.3 \mathrm{~m}$ contours for ponds): A) bench pond 1; B) bench pond 2; and C) bench pond 3.

Figure 3.8. Geomorphic landform design with valley ponds of experimental watershed and surrounding area in Logan County, WV, created using regional design inputs (15.2 m contours for watershed; $0.3 \mathrm{~m}$ contours for ponds): A) valley pond 1 ; B) valley pond 2; and C) valley pond 3 .....

Figure 3.9. Pre-Surface Mining Control and Reclamation Act (SMCRA) mining activity areas in

West Virginia and Logan County, WV (inset)....

Figure 4.1. a) Original topography of experimental watershed in Logan County, WV, b) completed conventional valley-fill design for experimental watershed, c) completed geomorphic landform design using regional data inputs for experimental watershed.... .48

Figure 4.2. Slope (\%) of the experimental watershed: a) original topography, b) completed conventional valley-fill, c) completed geomorphic landform design ..................................49 Figure 4.3. Hourly precipitation data from WV465353 meteorological station in Logan, WV ...52 Figure 5.1. Clear Fork experimental watershed, delineated with labeled subwatersheds............81 Figure 5.2. Clear Fork experimental watershed, delineated with 2001 land use .......................82 Figure 5.3 Dry Creek weather station average hourly precipitation from 06-01-2000 to 03-312009.

Figure 5.4. Dry Creek average annual hourly precipitation (2002-2008) and historical average precipitation comparison

Figure 5.5. Initial model run observed and modeled daily flow comparison (modeled flow in red and observed flow in blue)

Figure 5.6. Calibrated model run observed and modeled daily flow comparison (modeled flow in red and observed flow in blue)

Figure 5.7. Modeled and observed daily flow comparison for HSPF model calibration (2001 2004)

Figure 5.8. Validated model run observed and modeled daily flow comparison (modeled flow in red and observed flow in blue) 
Figure 5.9. Modeled and observed daily flow comparison for HSPF model validation (20052009)

Figure 5.10. Clear Fork experimental watershed, delineated with labeled subwatersheds, and 2014 valley-fill areas

Figure 5.11. Flood frequency analysis for Clear Fork watershed using log-Pearson type III analysis using observed and modeled annual peak stormflow values (log-log scale). 105 Figure 5.12. Model predictions 1 and 2 daily flow comparison for 2011-2020 (traditional flow in red and GLD flow in blue)

Figure 5.13. Flood frequency analysis for Clear Fork watershed using log-Pearson type III analysis using observed, current traditional predicted, and current GLD predicted annual peak stormflow values (log-log scale).

Figure 5.14. Model predictions 3, 4 and 5 daily flow comparison for 2041-2050 (traditional flow in red, GLD flow in blue, and NLD flow in green)

Figure 5.15. Flood frequency analysis for Clear Fork watershed using log-Pearson type III analysis using observed, future traditional predicted, future GLD predicted, and future NLD predicted annual peak stormflow values (log-log scale).

Figure C.1. Trial 2 model run observed and modeled daily flow comparison (modeled flow in red and observed flow in blue)

Figure C.2. Trial 3 model run observed and modeled daily flow comparison (modeled flow in red and observed flow in blue)

Figure C.3. Trial 4 model run observed and modeled daily flow comparison (modeled flow in red and observed flow in blue)

Figure C.4. Trial 5 model run observed and modeled daily flow comparison (modeled flow in red and observed flow in blue)

Figure C.5. Trial 6 model run observed and modeled daily flow comparison (modeled flow in red

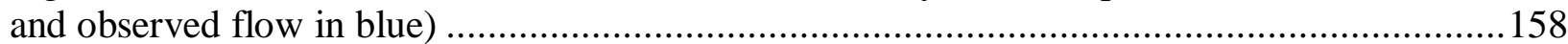
Figure C.6. Trial 7 model run observed and modeled daily flow comparison (modeled flow in red

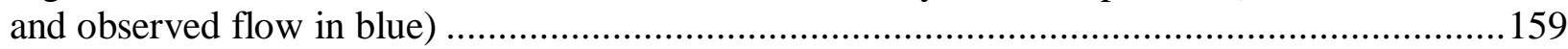
Figure C.7. Trial 8 model run observed and modeled daily flow comparison (modeled flow in red and observed flow in blue) ............................................................................... 160 Figure C.8. Trial 9 model run observed and modeled daily flow comparison (modeled flow in red and observed flow in blue) 161 Figure C.9. Trial 10 model run observed and modeled daily flow comparison (modeled flow in red and observed flow in blue) 162 Figure C.10. Trial 11 model run observed and modeled daily flow comparison (modeled flow in red and observed flow in blue) 


\section{List of Tables}

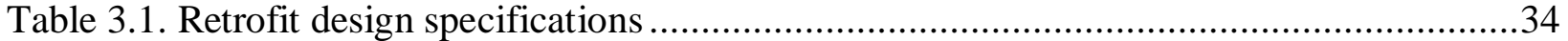

Table 3.2. Regional data GLD with bench ponds design specifications ......................................36

Table 3.3. Regional data GLD with valley ponds design specifications ....................................38

Table 3.4. Comparison of Traditional and GLD (Regional, Retrofit, Bench Pond, and Valley

Pond) Parameters …….................................................................................................. 40

Table 4.1. RUSLE input factors for each modeled condition of the experimental watershed .......57

Table 4.2. Average annual soil loss rates (A) and ranges for the undisturbed pre-mining condition, conventional valley fill post mining pre-vegetation condition, and conventional valley fill post-reclamation long term condition of the watershed separated into comparison areas (total area, reclaimed forest, reclaimed pastureland, and undisturbed surrounding area) .....................67

Table 4.3. Average annual soil loss rates (A) and ranges for the undisturbed pre-mining condition, GLD post mining pre-vegetation condition, and GLD post-reclamation long term condition of the watershed separated into comparison areas (total area, reclaimed forest, reclaimed pastureland, and undisturbed surrounding area) ....................................................72 Table 4.4. RUSLE input factors and average annual soil loss rates for each modeled condition of

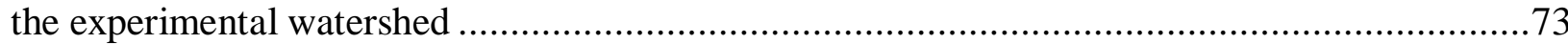

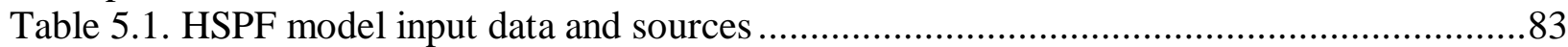

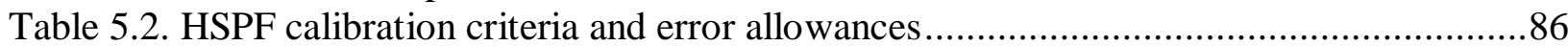

Table 5.3. Initial model run calibration criteria and model run results.....................................86

Table 5.4. Initial and calibrated HSPF model calibration runs parameters ..................................90

Table 5.5. Calibrated model run calibration criteria and model run results .................................90

Table 5.6. Validated model run validation criteria and model run results .................................93

Table 5.7. HSPF model predictions 1 (traditional) and 2 (GLD): land use alteration methods ....99

Table 5.8. HSPF model prediction 1 (traditional): current land use inputs.................................99

Table 5.9. HSPF model prediction 2 (GLD): current land use inputs ....................................... 100 Table 5.10. Current (2014) and projected (2050) valley-fill areas in experimental subwatersheds

Table 5.11. HSPF model predictions 3 (traditional) and 4 (GLD): land use alteration methods 102

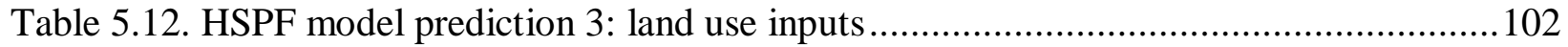

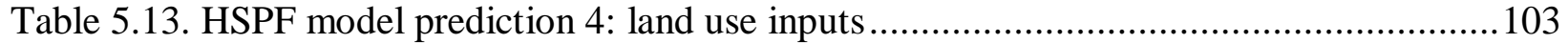

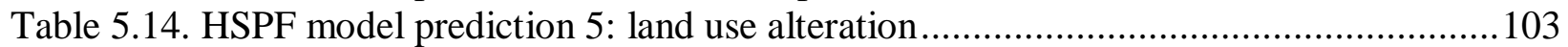

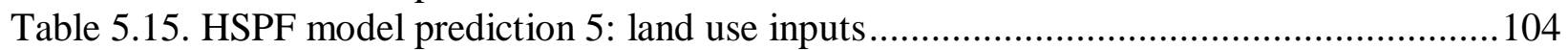

Table 5.16. Flood frequency calculations using log-Pearson type III analysis for observed and

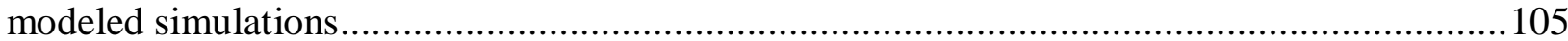

Table 5.17. Model predictions 1 (traditional) and 2 (GLD) comparison ................................... 108

Table 5.18. Flood frequency calculations using log-Pearson type III analysis for observed and

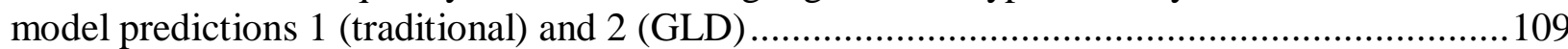

Table 5.19. Model predictions 1 (traditional) and 2 (GLD) average annual flow, annual peak stormflow, and average daily flow range ..........................................................................110 Table 5.20. Model predictions 1 (traditional) and 2 (GLD) average monthly flow and monthly

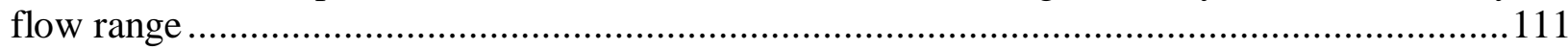

Table 5.21. Model predictions 3 (traditional) and 4 (GLD) comparison ..................................114 Table 5.22. Flood frequency calculations using log-Pearson type III analysis for observed and model predictions 3 (traditional), 4 (GLD), and 5 (no land disturbance) .................................115 Table 5.23. Model predictions 3 (traditional) and 5 (no land disturbance) comparison ..............116 
Table 5.24. Model predictions 4 (GLD) and 5 (No Land Disturbance) comparison.....

Table 5.25. Model predictions 3 (traditional), 4 (GLD), and 5 (no land disturbance) average annual flow and annual peak stormflow

Table 5.26. Model predictions 3 (traditional), 4 (GLD), and 5 (no land disturbance) average monthly flow and monthly flow range.

Table A.1. HSPF land use/land cover areas within each subwatershed

Table B.1. HSPF parameters for simulation of pervious land segments (PERLNDs), group 1 subroutine named "PWATER" used in this study for Clear Fork Watershed at Whitesville, WV

Table B.2. HSPF parameters for simulation of pervious land segments (PERLNDs), group 2 subroutine named "PWATER" used in this study for Clear Fork Watershed at Whitesville, WV

Table B.3. HSPF parameters for simulation of pervious land segments (PERLNDs), group 3 subroutine named "PWATER" used in this study for Clear Fork Watershed at Whitesville, WV

Table B.4. HSPF parameters for simulation of pervious land segments (PERLNDs), group 4 subroutine named "PWATER" used in this study for Clear Fork Watershed at Whitesville, WV

Table B.5. HSPF parameters for simulation of air temperature (ATEMP), subroutine named "ATEMP-DAT" used in this study for Clear Fork Watershed at Whitesville, WV

Table B.6. HSPF parameters for simulation of snow (SNOW), subroutine named "ICE-FLAG" used in this study for Clear Fork Watershed at Whitesville, WV.

Table B.7. HSPF parameters for simulation of snow (SNOW), subroutine named "SNOWFLAG" used in this study for Clear Fork Watershed at Whitesville, WV

Table B.8. HSPF parameters for simulation of snow (SNOW), subroutine named "SNOWPARM1" used in this study for Clear Fork Watershed at Whitesville, WV

Table B.9. HSPF parameters for simulation of snow (SNOW), subroutine named "SNOWPARM2" used in this study for Clear Fork Watershed at Whitesville, WV

Table C.1. Model run results for calibration trial 2 


\section{Introduction}

Surface mining and valley-fill activities are the dominant driver of land use/landcover change in the central Appalachian ecoregion of the United States (Saylor, 2008; Palmer et al., 2010). Surface coal mining involves the removal of vegetation, soil, and rock for the extraction of coal reserves. Overburden produced during the mining process is deposited in nearby engineered valley fills with benched fill faces and planar slopes, resulting in the burial of original topography and headwater streams (Palmer et al., 2010; Miller and Zegre, 2014).

Conventional valley-fill construction methods often lead to hydrologic impacts within the watershed they are located (Palmer et al., 2010; Miller and Zegre, 2014). Reclaimed mine land is consolidated by heavy equipment, leading to reduced infiltration rates, increases in stormflow runoff, and flood frequency, and alterations in the magnitude of downstream flooding (Brun and Band, 2000; Negley and Eshleman, 2006; Ferrari et al., 2009; Miller and Zegre, 2014). Valleyfill construction and the filling of headwater streams also frequently result in detrimental impacts to downstream channels, including changes in thermal regime and chemistry, increased sedimentation, and elevated conductivity and metal levels (Hartman et al., 2005; Pond et al., 2008; USEPA, 2005, 2011). Ecological impacts associated with mining and reclamation activities have been identified as disturbances in ecological function, aquatic habitat, riparian vegetation, and amphibian and macroinvertebrate populations (Pond et al., 2008; Petty et al., 2013).

Valley-fill reclamation designs that implement fluvial geomorphic landform principles have the potential to mitigate impacts associated with conventional techniques (Bugosh, 2009; Martin-Duque et al., 2010). This innovative geomorphic landform reclamation technique is an innovative alternative to conventional valley-fill reclamation and has been successfully implemented in locations outside of Central Appalachia, particularly in semi-arid regions (e.g. Toy and Chuse, 2005; Measles and Bugosh, 2007; Martin-Moreno et al., 2008; Martin-Duque et al., 2010); however, geomorphic landform design (GLD) has not been implemented in Central Appalachia to date due to the steep terrain, increased precipitation, complexity of design and construction, and regulation stringencies (Michael et al., 2010; Hopkinson et al., 2015b). Purported benefits of GLD including hydrologic balance, reduced erosional adjustments, and on site stream mitigation have been identified through modeling and construction (Toy and Chuse, 2005; Bugosh, 2009; Sears et al., 2013; Hopkinson et al., 2015b). 
Mining companies are required by law to mitigate stream channel impacts from surface mining and valley-fill activities (Palmer and Hondula, 2014). Original channels buried during valley-fill construction are often mitigated nearby through the restoration of degraded streams in previously mined watersheds, as opposed to the creation of streams on site due to the complexity and difficulty involved (Northington et al., 2011; Palmer and Hondula, 2014). GLD allows the creation of streams on site, allowing stream mitigation credits to remain on site. GLD creates sub-basins with complex (concave-convex) slope profiles and channelized flow paths and hydrologic features include rock ditches along the fill face and perimeter channels around the fill crest that are sized to convey a 100-yr, 24-hr storm event (WVDEP, 1993). However, the effectiveness of replacing the undisturbed hydrology with created hydrologic structures on spoil material has not been fully researched (USEPA, 2011).

Previous research on GLD implementation in Central Appalachia has been performed through modeling, as no GLD site has been constructed in Appalachia to date. Modeling focusing on slope stability (Russell, 2012; Russell and Quaranta, 2013), storm response (Snyder, 2013; Hopkinson et al., 2015b), flooding risk (O’Leary, 2014; Hopkinson et al., 2015b), and implementation challenges (DePriest et al., 2015). However, GLD prediction modeling of erosion at the watershed scale and hydrologic response at the landscape scale have not been researched. Hydrologic analyses of a GLD at the landscape scale compared to the undisturbed land condition and a conventional valley-fill design also has not been completed.

Hydrologic response is the process of rainfall transitioning to runoff and includes watershed routing, loss, and storage processes (Kult et al., 2015). Due to the extensiveness of surface mining in Central Appalachia, research on the hydrologic impact at the landscape scale is important for determining altered stream flows and volumes within the disturbed area and downstream areas (Ferrari et al., 2009). Hydrologic responses are difficult to accurately predict; however, accurate predictions have important implications for the mitigation of potential flood damages (Eshleman, 2004; Ferrari et al., 2009). Improved understanding of the hydrologic impacts at multiple stages in the surface mining and reclamation process could lead to improved mining and reclamation methods in which water quantity and quality problems and ecosystem degradation are minimized (Miller and Zegre, 2014).

Soil erosion is a natural process that occurs on undisturbed and disturbed (mined and reclaimed) lands in which surface soil is transported across Earth's surface, mainly by wind and 
water forces (Kouli et al., 2009; Demirci and Karaburun, 2012). Soil transported by erosion often carries nutrients and contaminants into streams and ground water resources (Nyakatawa et al., 2001; Kouli et al., 2009). Surface mining and valley-fill construction methods increase the possibility of soil erosion because of the large areas of barren land for prolonged times (Kouli et al., 2009). Excessive soil erosion can lead to changes in the shaping of the landscape and sediment load in nearby streams (Chen et al., 2011). Mine soils transported by erosional forces often include contaminates such as selenium, copper, and zinc which can also impact the health of downstream channels (Miller et al., 2011). Accurately predicting erosion is important for determining the impact on landscape, sediment load, and contaminants in on-site and nearby bodies of water (Chen et al., 2011).

\subsection{Research Objective and Questions}

The overall research objective of this project was to evaluate hydrologic response and erosion potential of geomorphic landform design application in surface mining reclamation, with the expectation to enhance the valley-fill reclamation techniques in Central Appalachia. The following specific research questions were posed to meet the main objective:

1. Can stream mitigation be implemented on surface mine valley-fill sites in Central Appalachia?

2. Is soil loss altered at the watershed scale by different valley-fill reclamation methods?

3. How is the hydrologic response altered at the landscape scale by different valleyfill reclamation methods?

This dissertation was organized as three main research chapters, written as separate manuscripts. Chapter 3, Valley-Fill Designs using Geomorphic Landform Principles, addressed the first research question. Alternative valley-fill reclamation designs implementing geomorphic landform principles and on-site stream mitigation were illustrated. Chapter 4, Soil Erosion Estimation using Revised Universal Soil Loss Equation (RUSLE) and Geographic Information System (GIS), focused on the second research question. Erosion rates and spatial distribution were predicted for multiple reclamation scenarios using RUSLE and GIS. Chapter 5, Hydrologic Response of Valley-Fill Designs at the Landscape Scale, answered the third research question. 
Stream flows and volumes were predicted at the landscape scale using Hydrologic Simulation Response-FORTRAN (HSPF). Each of the research questions and companion chapters were completed to achieve the overall research objective. Chapter 2, Literature Review, provides an extensive literature review for the support of this research. Chapter 6, reports the main conclusions of this research. 


\section{Literature Review}

\subsection{Valley-Fill Designs using Geomorphic Landform Principles}

\subsubsection{Regulatory Methods}

Surface mine reclamation and valley-fill construction throughout the U.S. are regulated according to the Surface Mining Control and Reclamation Act of 1977 (SMCRA). Prior to the SMCRA, surface mining practices were unregulated and resulted in erosion, geotechnical stability, seepage, and hydrology issues (Daniels et al., 2004). Since the implementation of SMCRA, reclamation by approximate original contour (AOC) design has been the conventional method practiced in the U.S. In West Virginia, AOC guidelines are promulgated by West Virginia Surface Mining Reclamation Regulations (WVSMRR), Code of State Regulations (CSR) $\$ 38$ which require reclaimed slope profiles to be constructed by the traditional backfilling technique. The reclamation requirements are comprehensive, covering drainage structures, slope consolidation and grading, and revegetation. The post-mining slope design was intended to ensure slope stability, control drainage, complement the drainage pattern of the surrounding terrain, and prevent stream sedimentation (Sears et al., 2013). The State also permits variances to the $\mathrm{AOC}$ regulations for special circumstances if the post-mining land use is determined to be better than the original land use, such as pastureland, commercial use, or school sites.

Despite the extensive regulations, environmental concerns over the loss of headwater stream length and downstream disturbance that are not completely mitigated during reclamation have become an ever-growing issue (Palmer et al., 2010; Schnoor, 2010; Lindberg et al., 2011; Wickham et al., 2013). The West Virginia Department of Environmental Protection (WVDEP) and the US Environmental Protection Agency (EPA) implement the Clean Water Act of 1972 through the National Pollution Discharge and Elimination System (NPDES) to provide requirements for drainage and sediment control requirements for the quality of the discharged runoff. Surface runoff is regulated on conventional valley-fill reclamation sites by hydrologic control structures and Surface Water Runoff Analysis (SWROA) ditches and groin ditches. SWROA and groin ditches are typically located along the perimeter of the fill area and down the fill face and are designed for a 100-yr, 24-hr storm event. 
Reclamation revegetation requirements in West Virginia involve the use of select grasses and hardwoods that have proven effective in partially concealing the planar slope profiles and surface drainage structures. However, excess consolidation of reclaimed soils, caused by the use of heavy machinery, often hinders large tree root development, leading to lower tree canopy height than pre-disturbed canopy and rarely acquiring pre-disturbed land cover (Graves et al., 2000; Miller and Zegre, 2014).

\subsubsection{Geomorphic Landform Design (GLD)}

The need to balance valley-fill stability with hydrologic balance and a natural appearance has opened the opportunity to introduce an alternative reclamation design: geomorphic landform design (GLD) (Sears, 2012). Under natural conditions, landforms develop a balance between erosive and resistance forces, resulting in a system in hydrologic equilibrium with minimal erosion. The fluvial geomorphic landform design approach attempts to design landforms in this steady-state condition, considering long-term climatic conditions, soil types, slopes, and vegetation types (Toy and Chuse 2005; Bugosh 2009).

Recent research presented the use of geomorphic landform principles in an innovative reclamation technique for surface mined lands and valley fills with the potential to improve the unfavorable impacts within the watershed they are built (Sears, 2012; Russell and Quaranta, 2013; Sears et al., 2013; Sears et al., 2014). Geomorphic landform design has the potential to mitigate stream loss due to surface mining and valley-fill operations. The technique endeavors to design landforms in a steady-state condition with a balance between erosive and resistance forces, considering long-term climatic conditions, soil types, slopes, and vegetation types (Toy and Chuse 2005; Bugosh 2009).

\subsubsection{Reference Watershed Stream Channel Design}

The geomorphic landform reclamation method uses a reference landform approach which requires local geomorphic information. Reference data necessary to inform successful design, includes the main channel slope and landform profile shape, drainage density and area, and channel characteristics (Toy and Chuse, 2005; Eckels and Bugosh, 2010). Main channel slope represents the watershed slope; as the main channel slope increases, the stream power and erosion potential increase (Toy and Chuse, 2005). Stream characteristics that must be considered when designing hydrology that will properly manage both sediment discharge and flow include 
bankfull width, width-to-depth ratio, meander belt width, A-channel reach length, ridge to headof-channel length, and sinuosity (Eckels and Bugosh, 2010). A-channel reach length is defined as the distance of one-half of a meander length in steep channels. Ridge to head-of-channel distance defines the length required to form concentrated flow, while also defining the channel head location in reference to the watershed boundary. The longitudinal profiles of the landforms must also be considered as the shape changes among headwater and downstream locations, convex to concave. In mountainous terrain, the slope profiles develop into compound surface profiles which exhibit steep convex slopes at the head of the valley and progressively transition into a concave form gradually tapering to a uniform profile. Channels also vary in characteristics depending on location within the watershed (Sears et al., 2013). Headwater streams are often steep ( $>4 \%$ slope), characterized as "A" channels as defined by the Rosgen classification system (Rosgen, 1994), and relatively straight (sinuosity = 1.0-1.2), and down-stream channels have a lower gradient (<4\% slope), C-channels, and increased sinuosity (>1.2; Rosgen, 1994).

The development of natural streams on the complex geomorphic profiles is affected by fluvial influence stream cutting, surficial erosion, and rill-to-gully erosion. To minimize the erosive forces, the drainage density for each designed stream must meet the target drainage density requirements. Drainage density is the measure of the average stream channel spacing, is calculated as the stream length per watershed area, and results from flow interactions with sediment and soil, vegetation, topography, and weather variables (Bugosh, 2004; Toy and Chuse, 2005). For a given reference landform, the drainage density describes the drainage network that can be supported without significant aggradation or erosion (Bugosh, 2004). However, limited landform and stream channel characteristic data were available in West Virginia, especially in the southern coal fields (Wiley et al., 2001) prior to the Buckley et al. (2013) study. Buckley et al. (2013) collected reference landform data including ridge to head-of-channel distance (108$163 \mathrm{~m})$ and drainage density $\left(5.3 \mathrm{~km}^{-1}\right)$ from an undisturbed watersheds in southern West Virginia.

\subsubsection{Implementation Challenges}

The geomorphic reclamation method has been used with success in the Southwestern USA and outside of the USA and designs landforms, including ridges, valleys, and channels, in an erosive steady-state condition (Toy and Chuse, 2005; Martin-Moreno et al., 2008; Bugosh, 
2009; Martin-Duque et al., 2010). However, this reclamation design method has not been adequately analyzed for potential implementation in Central Appalachia, nor have all improvements or disadvantages over conventional valley-fill reclamation designs been scientifically established (Sears et al., 2014). Challenges associated with applying the technique in Central Appalachia include the steep terrain, current regulation framework, and perceived reclamation costs (Michael et al., 2010).

Challenges associated with the successful implementation of the geomorphic landform reclamation method in Central Appalachia extend beyond the difficulty and complexity of designing and constructing stable fill structures in steep terrain. Additional challenges include regulation alteration for approval of designs, determining geotechnical stability of designed landforms, demonstrating hydrologic responses of design implementation, and complexity of earthwork leading to potential extended construction times (Michael et al., 2010). Perceived initial construction costs of geomorphic reclamation designs are greater than traditional reclamation; however, long-term costs are proposed to be minimal due to little to no surface erosion and maintenance (Bugosh, 2009; Michael et al., 2010).

Depriest et al. (2015) listed potential challenges of applying geomorphic design principles to surface mine reclamation in Central Appalachia that included:

- "Geomorphic design criteria must be measured locally;

- Constructing artificial landforms that naturally blend into the steep slopes of the surrounding environment may not ensure stability;

- Shallower, more stable slopes of geomorphic landforms could create greater stream burial to maintain fill volumes."

In addition to implementation and regulation challenges, the impact on hydrologic response, considering surface water, needs to be better understood prior to implementation (Michael et al., 2010; Depriest et al., 2015).

\subsubsection{Geomorphic Landform Design (GLD) for West Virginia Site}

Sears (2012) created a valley-fill design, an alternative of the conventional design, for a study valley-fill site $\left(0.98 \mathrm{~km}^{2}\right)$ in southern West Virginia, USA using geomorphic landform principles. Geomorphic landform design principles are based on the creation of mature, stable landforms. The software design tool Carlson ${ }^{\circledR}$ Natural Regrade ${ }^{\circledR}$ with GeoFluv ${ }^{\mathrm{TM}}$ was used with 
default data inputs due to lack of regional data availability. The design resulted in sub-basins that directed flow to stream channels (main channel and 12 tributaries) that were created as part of the design of the new valley fill as opposed to the control structures and SWROA ditches typical in conventional design. The stream channels (9,660 m total combined length; 148-1,612 $m$ length range) were designed to mimic the original dendritic drainage. Elevation of the designed site ranged from 350 to $608 \mathrm{~m}$. Purported features of the design included complex slope profiles (concave to convex), improved hydrology and groundwater movement, and decreased flooding risk (Sears, 2012).

\subsubsection{Slope Stability}

Slope stability analysis is a critical part of surface mine reclamation design analysis because slope failure can have significant ecological impacts (Kenney and Lau, 1985). Natural Regrade with GeoFluv ${ }^{\mathrm{TM}}$ software currently bases landform creation on mature, stable landforms instead of providing a full slope stability analysis (Sears et al., 2013). It is important that reclamation landforms remain stable when constructed with surface mine overburden for several reasons. Typically, toxic mineralogy exists within the spoil material (Miller et al., 2011). Therefore, slope stability becomes a critical analysis that should be performed during the design planning process to determine placement of the contaminated soil to minimize water contact. It is especially important to perform slope stability analysis to ensure the durability of the structure in Central Appalachia due to the steep, rugged terrain. All created landforms, whether created using conventional or geomorphic principles, should be analyzed in order to limit the steepness of slopes and insure the stability of the landforms. Slope failures can have significant impacts on the health and safety of downstream communities as well as the operators constructing the structures (Sears et al., 2013).

Further research on the Sears (2012) GLD included a complete slope stability analysis to determine the stability of the landforms created in the geomorphic reclamation designs for Central Appalachia. Initial research suggested that geomorphic landform reclamation was comparable to conventional valley fill construction and could provide potential reclamation benefits in terms of groundwater seepage and slope stability. An analysis of the slope stability resulted in a factor of safety greater than 2 for the Central Appalachian GLD (Russell and 
Quaranta, 2013), meeting the requirements of conventional valley fills in West Virginia (WV factor of safety = 1.5; WVDEP, 1993).

\subsubsection{Stream Mitigation on Mine Sites in Appalachia}

Mining companies are required to mitigate impacts on streams from mining and valleyfill activities according to section 404 of the Clean Water Act (Palmer and Hondula, 2014). The U.S. Army Corps of Engineers reviews mining permit applications in which judicial "waters of the U.S.” would be impacted and approves mitigation plans. Compensatory mitigation, restoration of streams off site, is relied heavily upon to meet mitigation regulations (Palmer and Hondula, 2014). Many coal companies restore streams located on older mined areas that have been impacted by mining-related disturbances, as compensatory mitigation, which is often easier than creating stream channels on site for mitigation (Northington et al., 2011).

Past stream creation practices for mined areas involved constructing channels with morphologies mimicking unaffected streams, but the topography, vegetation, soils, hydrology, and water chemistry of the site were dramatically altered from the pre-mining state (Palmer et al., 2010). Stream creation on site is an important form of mined land restoration and mitigation; however, little is known about the success and efficacy of on-site stream mitigation (Palmer et al., 2010; Palmer and Hondula, 2014). Palmer and Hondula (2014) stated that data from 434 stream mitigation projects from 117 surface mining permits showed that mitigation efforts implemented on southern Appalachia coal mining sites did not meet the objectives of the Clean Water Act to replace lost or degraded stream ecosystems and their functions.

Petty et al. (2013) investigated ecological function through stream flow, aquatic habitat, water chemistry, riparian vegetation, and amphibian communities of five reference stream channels to five constructed stream channels on reclaimed sites in southern West Virginia. Compared to the reference streams, the constructed streams had significantly higher levels of conductivity, total dissolved solids, OM retention, OM processing, and dissolved carbon concentrations. Macroinvertebrate and amphibian richness were comparable between reference and constructed channels. Petty et al. (2013) also noted that as the reclamation sites matured, conductivity slightly declined and total invertebrate richness significantly increased.

Northington et al. (2011) assessed compensatory stream mitigation on older coal mining areas in Virginia. Six restored and three unrestored streams in the coal mining region of 
southwest Virginia were studied and compared. No significant differences were found between physicochemical and functional variables or between structural and functional measurements. However, invertebrate community metric scores were higher in the unrestored streams compared to the restored streams. Principal components analysis by Northington et al. (2011) implicated the importance of physicochemical, structural, and functional variables measurement in future restoration efficacy analyses.

\subsubsection{Stream Channel Bed Design on Valley Fills}

Stream channels have been constructed on the surface of valley fills with varied success (Petty et al., 2013). Common stream restoration methods (e.g. natural channel design) are currently used to restore existing streams rather than create new channels on the valley fill (USEPA, 2011). Often, original stream channels buried during valley-fill construction are mitigated in locations where no original streams were located, resulting in little to no hydrologic improvement to the original stream areas (Northington et al., 2011). Creation of streams on valley fill surfaces has not had widespread implementation due to the complexity and difficulty involved (Northington et al., 2011; Palmer and Hondula, 2014). Challenges associated with the successful implementation of stream channels on top of valley fills in Central Appalachia include channel design, placement, and construction materials.

\subsubsection{Constructed Stream Channels on Reclaimed Surface Coal Mines}

Streams and wetlands provide valuable habitat for a plethora of wildlife and vegetative species (Balcombe et al., 2005; Finn et al., 2011; Petty et al., 2013). Headwater streams and wetlands provide a complex network of ecological services including flood mitigation and water quality improvement (Meyer and Wallace, 2011; Petty et al., 2013). Surface mining and valley fill construction can cause alteration or burial of natural stream channels (USEPA, 2005; Petty et al., 2013). A cumulative loss of stream and wetland functions from surface mining activities can cause detrimental impacts to larger bodies of water downstream of impacted waters (Palmer et al., 2010; Merriam et al., 2011; Petty et al., 2013).

Studies of perennial stream channels constructed on surface mines in southern West Virginia determined that habitat quality was consistently higher in natural stream channels than in constructed channels (Petty et al., 2013). The principal negative characteristics of the stream channels constructed on reclaimed surface mine sites was elevated total dissolved solids (TDS) 
and electrical conductance (Petty et al., 2013). Two ways to mitigate the excess TDS and electrical conductance in the constructed streams include improved mine spoil handling during reclamation and construction of sulfate-reducing wetlands as part of mine reclamation (Petty et al., 2013).

Precipitation can infiltrate quickly into mine spoil causing many stream channels constructed on reclamation sites to remain dry a large majority of the year (Petty et al., 2013). Traditionally, the only perennial stream channels that are constructed on surface mine reclamation sites are low gradient and are located along the mine perimeter adjacent to the constructed valley fills (Petty et al., 2013). Additional research and analysis are required to determine a sustainable and cost-effective constructed stream channel sub-base design that minimizes surface water infiltration into the base fill layer, poses inherent structural sustainability against erosion, subsidence, and suffusion/suffusion, and offers competitive cost and installation practicality.

\subsubsection{Stream Bed Design Materials}

Geocells and geogrid mattresses could provide a successful base for the created stream channels on valley-fill surfaces. Geocells are rigid polymer strips and geotextiles that are organized vertically in a boxlike fashion, placed horizontally, and filled with soil or sand (Koerner, 1998). Geocells physically confine the soil or stone, resulting in improved granular soil shear strength and excellent bearing capacity which is an improvement over relying on friction, arching, and entanglements of fiber or mesh for improved soil performance (Koerner, 1998). One disadvantage of using geocells is that the dynamic effects of sand and soil particles under the geocells and gradually lifting it up out of position has not been tested (Koerner, 1998).

Another option is the use of three-dimensional mattresses, which consists of a deeper, more rigid geocell filled with gravel (Koerner, 1998). Over the past thirty years geocell mattresses have been widely used in soil reinforcement due to their three-dimensional configuration, which confine and reinforce the soil and stone within the cell pockets (Zhang et al., 2012). The confinement of the soil and stone provided by the geocell mattress can also increase soil stiffness and reduce soil deformation (Zhang et al., 2012). It has also been observed that geocell reinforcements placed at the subgrade-base interface or within the base course can 
substantially increase load-carrying capacity and decrease footing settlement (Dash et al., 2001; Zhou and Wen, 2008; Pokharel et al., 2010; Zhang et al., 2012).

Koerner (1998) shows an example of a three-dimensional geogrid mattress being filled with gravel for landfill bearing capacity over soft mine tailings in Hausham, Germany. The geogrid mattress was $1 \mathrm{~m}$ high and was constructed to support a $30 \mathrm{~m}$ high landfill over the mine tailings which were covered with a nonwoven geotextile and a biaxial geogrid to provide a stable working area for construction (Koerner, 1998). Similar to the geocells filled with soil or sand, three-dimensional geogrid mattresses improve global slope stability, increase bearing capacity, and decrease lateral extrusion (Koerner, 1998). Koerner (1998) states:

"Global slope stability is improved by forcing the potential failure plane through the mattress and deeper into the foundation soil. It is also possible that the foundation soil may improve in strength characteristics at greater depths. Bearing capacity is improved in a similar manner to the point where it becomes a nonissue for mattresses greater than approximately $30 \mathrm{~m}$ in width. Lateral extrusion (or squeeze-out) is undoubtedly decreased because stress concentrations have been largely eliminated via a uniform pressure through the relatively stiff geogrid mattress."

Geotextiles would also be valuable for successful stream channel construction on valleyfill materials in order to provide a barrier between fill material and water in the streams. Geotextiles were originally used in erosion control applications as an alternative to granular soil filters (Koerner, 1998). Today, there is a plethora of types of and uses for geotextiles. Nonwoven geotextiles are primarily used for separation and filtration and typically have a higher permeability than woven geotextiles. Woven geotextiles have been used for years for numerous applications such as separation, filtration, drainage, protection, reinforcement, erosion protection, and confinement (Tencate, 2014). The properties and design specifications of the woven geotextile determines the application and engineering use(s) such as slope reinforcement, water/waste containment, and roadway applications. Woven geotextiles would be beneficial for the construction of stream channels on valley fills by providing a barrier that prevents fill soil from migrating into the stream bed materials.

Geosynthetic clay liners (GCLs) will be beneficial for successful stream channel construction on valley-fill materials in order to prevent stream water from infiltrating into the fill material. Geosynthetic clay liners have been used for decades in environmental containment 
applications as an alternative to traditional compacted clay liners (CETCO, 2014). The sodium bentonite within the GCL creates a layer of low permeability which is ideal for use in stream channel sub-bases, landfills, and water catchments. However, one concern is the compatibility of the bentonite clay material within the geosynthetic clay liners with the exchangeable cations in the fill material must be analyzed to achieve a comprehensive design. GCLs are geosynthetic products which use bentonite as a hydraulic barrier (Quaranta et al., 1997). Due to the construction material of GCLs, high quality sodium bentonite, their placement in a material with high concentrations of dissolved calcium ions can affect the long-term hydraulic function of the GCL (Quaranta et al., 1997). The acetic acid permeant enriched with calcium is aggressive in increasing the hydraulic conductivity of the bentonite component of GCLs (Quaranta et al., 1997). Therefore, the soil at the site must be analyzed to properly determine if soil will affect the long-term sustainability of the GCL.

Today, GCL technology has evolved and geomembrane supported GCLs are constructed to provide the benefits of the swelling and sealing of the bentonite clay with the chemical resistance and impermeability of the polyethylene geomembrane (GSE, 2014). This geomembrane supported GCL would also be ideal for stream channel sub-bases, landfills, and water catchments with added benefits over traditional GCLs.

\subsection{Soil Erosion Estimation using Revised Universal Soil Loss Equation (RUSLE) and Geographic Information System (GIS)}

\subsubsection{RUSLE and GIS}

Geographic Information System (GIS) and remote sensing tools have been used effectively in cooperation with many different models, such as Revised Universal Soil Loss Equation (RUSLE), to predict soil loss (Demirci and Karaburun, 2012). GIS provides an indepth analysis of individual factors such as soil type, slope and land use (all of which contribute to soil erosion) and is beneficial when used with RUSLE to estimate soil erosion at the watershed level (Demirci and Karaburun, 2012). Many studies have used GIS and RUSLE to assess and predict soil erosion and sedimentation due to land use change, primarily agricultural and urbanization, (Fernandez et al., 2003; Ranzi et al., 2011; Demirici and Karaburun, 2012). 
However, few studies have used these methods to predict soil erosion and sedimentation due to surface mining and reclamation land use change (Evans and Loch, 1996).

\subsubsection{RUSLE Factors Controlling Erosion of Mine Soils}

Evans and Loch (1996) evaluated the effects of site specific mine spoil properties on soil erosion rates through the derivation of the Revised Universal Soil Loss Equation (RUSLE) parameter inputs for two mine sites in Australia. It is commonly accepted that soil erosion increases as slope steepness and rainfall increase, however, it is also likely that factors such as differences in surface characteristics influence erosion and runoff (Evans and Loch, 1996). Particle size analyses were performed by Evans and Loch (1996) on bulk soil samples from the upper $10 \mathrm{~mm}$ of the surface that were collected randomly from the two study sites. Evan and Loch (1996) used the particle size data, the erodibility factor $(\mathrm{K})$ input was determined using the Rosewell and Edwards (1988) equation. Slope length and steepness factor (LS) were estimated by Evans and Loch (1996) through applying observations of the two sites to Renard et al. (1994) LS values. The cover and management factor $(\mathrm{C})$ was calculated using the erosion rate ratio from Simanton et al. (1982). No support practices were implemented at the sites, therefore, the conservation practice factor $(\mathrm{P})$ was 1 .

Evans and Loch (1996) concluded that one of the two sites resulted in greater erosion due to the increased compaction and higher bulk density of that site. The studied surface conditions of the two sites were not final reclaimed condition of the sites as the site had not undergone revegetation. However, this study would be applicable to soil erosion estimation as mining occurred, prior to reclamation.

\subsubsection{Modeled Hydrology and Erosion on Valley Fills (Geomorphic and Traditional)}

Warner et al. (2009) compared two alternative approaches to valley-fill construction, traditional and geomorphic, along with predictive modeling results to an undisturbed Appalachian forest. The program SEDCAD was used for modeling the valley-fill crests for each of the scenarios. The crest was chosen as the focus of the study since it was most affected by the alternative valley-fill design techniques. Selection of model input parameters was predominately based on measured values from undisturbed, compacted, and loose-dumped research watersheds adjacent to the geomorphic valley fill (Warner et al., 2009). For the undisturbed scenario model, hydrologic data were obtained from an undisturbed, forested watershed approximately $5 \mathrm{~km}$ 
from the study site. Sedimentologic inputs, including erosivity factor (K), eroded particle distribution (EPSD), slope length and steepness factor (LS), and cover factor (C), were obtained from the study site or surrounding areas in Kentucky. Hydrologic and sedimentologic inputs for the traditional valley-fill scenario model were estimated using data collected from nearby mine sites.

Model inputs for the geomorphic valley-fill scenario were difficult to obtain and resulted in estimations due to limited available data on hydrologic characteristics of loose-dumped spoil material (Warner et al., 2009). Hydrologic data were estimated based on a few hydrologic assessments of loose-dumped spoil sites. Sedimentological inputs were obtained from research sites or estimated from site observations. Predicted peak flow, runoff volume, sediment load, and peak sediment concentration for the crown of the traditional and geomorphic valley-fill designs were compared to the undisturbed watershed to determine erosion and hydrologic impacts. Model results indicated that peak flow increased for the traditional fill while peak flow decreased for the geomorphic fill compared to the pre-mining condition (Warner et al., 2009). Compared to the undisturbed scenario, peak sediment concentration increased approximately $25 \%$ for the traditional fill and was approximately equal for the geomorphic fill (Warner et al., 2009). Future research needs were also stated and included hydrologic and sedimentology data for traditional and geomorphic valley-fills to be used for future modeling. This study was a base for much needed hydrologic and erosion research for valley-fill sites constructed using conventional and geomorphic design methods. Further research on valley fill hydrology and erosion is needed for accurate future modeling and comprehension.

\subsubsection{Soil Erosion Mapping Using RUSLE and GIS}

Chen et al. (2011) applied the Revised Universal Soil Loss Equation (RUSLE), geographic information system (GIS), and remote-sensing technique to map the soil erosion risk within a watershed $\left(15,788 \mathrm{~km}^{2} ; 150-1,800 \mathrm{~m}\right.$ elevation, $488.9 \mathrm{~mm}$ annual average rainfall) in North China. The RUSLE was utilized in a GIS environment by creating each of the input factors as a data layer and multiplied in GIS to determine the spatial distribution of the soil erosion risk within the study watershed.

The rainfall erosivity factor $(\mathrm{R})$ was calculated using the Bu et al. (2003) equation using monthly and annual rainfall totals and rainfall intensities. The soil erodibility factor $(\mathrm{K})$ was 
estimated using Wischmeier and Smith (1978) with obtained soil data including dominant particle sizes, soil structure, and percentages of clay, silt, sand, organic matter. The cover factor (C) was calculated from the predominant crops using remote-sensing data and the back propagation (BP) neural network, an error-based algorithm (Chen et al., 2011). The slope length and steepness factor (LS) was calculated using separate equations for slope gradients of less than $21 \%$ or greater than $21 \%$ (Renard et al., 1997). The conservation practices factor (P) was assumed to be 1 because only a very small area of the watershed had conservation practices implemented.

Modeling results showed a spatial distribution of the erosion risk within the study watershed. Chen et al. (2011) stated that in terms of erosion, soils have serious risk due to hilly topography, soil conditions (i.e. fine texture, low organic matter, poor plant coverage), and excessive land use and land cover changes such as agricultural practices and surface mining. Reduction of soil erosion, particularly in headwater areas, was necessary to protect the water quality within the watershed. Through spatial erosion risk results, areas that are at severe erosion levels could be identified and management practices could be implemented.

\subsubsection{Average Sediment Yield of Reclaimed Mine Spoil}

Hoomehr et al. (2015) quantified the erodibility of low-compaction, steep-sloped reclaimed surface mine lands in the southern Appalachian region. For the three active coal mining study sites in East Tennessee, sediment yield averaged $116 \mathrm{t} \mathrm{ha}^{-1}$ for the three month study period (June-August 2009) during which rill development occurred. Total sediment yield averaged $391 \mathrm{t} \mathrm{ha}^{-1}$ for the sites over the entire fourteen month study period (June 2009-July 2010).

Hoomehr et al. (2015) also reported sediment yield averages for multiple other studies of reclaimed mine spoil sites. Curtis and Superfesky (1977) reported the sediment yield from a $36 \%$ slope reclamation spoil in East Tennessee during a twenty month study period as $526 \mathrm{t} \mathrm{ha}^{-1}$. McIntosh and Barnhisel (1993) documented a sediment yield of $91.5 \mathrm{t} \mathrm{ha}^{-1}$ on a $9 \%$ slope in Eastern Kentucky. Sediment yields studied by Carroll et al. (2000), ranged from 314-1120 t ha ${ }^{-1}$ over a four year monitoring period for three slope gradients $(10,20,30 \%)$ on three central Queensland coal mines. Each of the studies reported rill development on site immediately following reclamation. 


\subsection{Hydrologic Response of Valley-Fill Designs at the Landscape Scale}

\subsubsection{Hydrologic Impacts of Land Use Alteration}

Limited research has been performed at the landscape scale $\left(100-1,000 \mathrm{~km}^{2}\right)$ to determine the effects of surface mining and valley-fill construction on watershed hydrology, particularly the movement and storage of water (Ferrari et al., 2009; Miller and Zegre, 2014). The limited knowledge about the hydrologic impacts of surface mining and reclamation in Central Appalachia came from very few studies whose research pales in comparison to other land use studies such as urbanization, forest harvesting, and agriculture (Miller and Zegre, 2014).

It has been suggested that urbanization could be paralleled to mined/reclaimed land (Ferrari et al., 2009), but there are limited research results to definitively correlate the two. Urbanization often leads to an increase in impervious surfaces, such as parking lots, roads, and structures, resulting in increased runoff magnitude and volume and decreased groundwater recharge (Miller and Zegre, 2014). Urbanized areas rapidly convert rainfall to runoff with high magnitude storm hydrographs and limited baseflow compared to forested systems (Miller and Zegre, 2014). Ferrari et al. (2009) related the hydrologic impacts of traditional surface mining and reclamation to being more similar to urbanization impacts as opposed to forest harvesting impacts. Forest harvesting typically results in reduced infiltration and increased runoff through the reduction of canopy interception and transpiration as well as soil compaction from machinery use (Miller and Zegre, 2014). Hydrologic impacts of surface mining and reclamation, depending on the site and conditions, may mimic impacts from many different land use alteration scenarios, but more research is needed for validation.

\subsubsection{Surface Runoff, Stormflow Response, and Flow Path Impacts}

Surface mining can alter the hydrologic balance of the disturbed area, resulting in a shift from subsurface to surface flow. This leads to changes in rainfall runoff ratios along with increased flood frequency and magnitude (Ferrari et al., 2009). Compaction of the spoil material during the reclamation process, resulting from the use of large earthmover equipment, also attributes to decreased infiltration capacity and tree growth, increased surface runoff, higher magnitude stormflows and flooding risk (Miller and Zegre, 2014). 
Similar to other land use changes, surface mining and reclamation also alter the catchment water budget by altering flow paths (Miller and Zegre, 2014). An overall increase in baseflow in surface mine and valley fill impacted areas in Appalachia has been documented by Green et al. (2000), Messinger (2003), and Messinger and Paybins (2003). Studies by Messinger (2003) and Wiley and Brogan (2003) documented increases in stormwater discharge in valley-fill watersheds in West Virginia.

Snyder (2013) and O'Leary (2014) modeled the potential hydrologic response of a GLD by evaluating storm response as well as the flooding of the receiving reach of one West Virginia valley fill in several construction phases (i.e., pre-mining, conventional design, GLD). Storm hydrographs were generated for the four landform conditions: 1) pre-mining; 2) conventional valley fill; 3) GLD during construction; and, 4) GLD post reclamation. The GLD during construction condition resulted in peak flowrates that were more than twice the undisturbed premining condition (O’Leary, 2014). Peak flowrates reduced to pre-mining conditions over time, illustrating that permanent water management structures were not required. A steady-state HECRAS analysis was completed to compare floodplain extents of the receiving reach of the reclamation site. Results indicated that stormwater control systems would be necessary during the construction of the geomorphic landforms (GLD during construction condition) and could be removed after vegetation was re-established (GLD post reclamation condition) (Snyder, 2013).

\subsubsection{Flood Response Effects Modeled with HSPF}

Ferrari et al. (2009) estimated surface mining and reclamation effects on flood response of watersheds in the central Appalachian Plateau region. Hydrologic Simulation ProgramFortran (HSPF) was used to estimate changes in flood response as a function of increased mining within a $187 \mathrm{~km}^{2}$ watershed in Maryland. US Environmental Protection Agency’s Better Assessment Science Integrating point and Non-point Sources (BASINS) was used to generate the main input file for the HSPF simulations. Ferrari et al. (2009) calibrated the HSPF model for ten years of stream flow data with the input land use/land cover centered within the time span. Calculated calibration statistics included Nash-Sutcliffe efficiency and percent differences in overall water balance, yearly water balance, monthly water balance, lowest $50 \%$ flows, highest $10 \%$ flows, overall flood volume, and peak flood flow. Flood statistics were calculated for the peak flow events for each calibration time period and represented flood response under a wide 
range of rainfall intensities and soil moisture conditions (Ferrari et al., 2009). Flood dates were determined as the three to five largest runoff events for each year in the calibration period. Dates for each flood event included one or more days prior and several days following each peak flow.

Results from the study showed that the rate at which flood magnitude increased due to increased mining was linear. The findings indicated that surface mining and reclamation resulted in landscape conditions more similar to urbanized areas than areas of deforestation. Ferrari et al. (2009) also questioned the effectiveness of current reclamation practices in terms of returning mined areas to the hydrological state that existed prior to mining. This suggested further research through hydrologic modeling of the hydrologic impact of surface mining would be beneficial to improve future reclamation practices.

\subsubsection{HSPF Calibration Parameter Examples for West Virginia}

Atkins et al. (2005), in cooperation with the United States Geological Survey (USGS) and the West Virginia Department of Environmental Protection (WV DEP) Division of Mining and Reclamation, presented HSPF parameters for streamflow simulation of eight watersheds in West Virginia disturbed by surface mining and reclamation. The eight study basins were chosen based on their lengthy available streamflow data with both undisturbed and mined periods of record. The areas were also chosen in a manner to provide an aerial distribution across the surface mining region in West Virginia. The study watersheds ranged in size from $79.8 \mathrm{~km}^{2}$ to $383.3 \mathrm{~km}^{2}$.

BASINS software was used to develop the initial input files for the basin modeling. The WinHSPF computer program was used to build a WinHSPF project and an initial HSPF simulation. Time series data, including precipitation and evaporation, from each watershed were stored in the data management files and used to drive the HSPF streamflow simulations. Model calibration and validation were achieved by using initial parameter values from a previous nearby model application, long calibration periods from 9.75 to 15.75 years, and examining periods outside of the calibration period (Atkins et al., 2005). Parameters were adjusted based on daily, monthly, and seasonal hydrographs and statistical comparisons to achieved accurate HSPF models for each study basin. The magnitude and relation of model calibration parameters, particularly relating to the effects of mining and reclamation, are necessary to facilitate proper application and accurate modeling of streamflow. The model parameters from Atkins et al. 
(2005) assist users of HSPF in simulation of streamflow in watersheds impacted by surface mining and reclamation in West Virginia.

\subsubsection{Future Hydrologic Research Needs}

Miller and Zegre (2014) completed an extensive review of research studies completed on mountaintop removal mining and catchment hydrology. Following a detailed description of mountaintop mining and valley-fill construction methods, a review of potential impacts of mountaintop-removal mining and valley fill on hydrology was discussed. Such impacts included land use change, increased runoff, biological impairment, soil compaction, altered or nonexistent flow channels, and infiltration. In addition to the research review, Miller and Zegre (2014) noted knowledge gaps and future research needed for better understanding of the hydrologic impacts resulted from surface mining reclamation and valley-fill construction. Discussed future research needs were presented in research question form and included (Miller and Zegre, 2014):

- "What are the dominant runoff generation processes in mountaintop mining impacted catchments?

- How do these processes change with increasing disturbance from mountaintop mining?

- How do these processes change with differing reclamation techniques?

- How do contemporary valley fills store, route, and release water?

- What variability exists within forested catchments in the Central Appalachian coalfields?

- What are the effects of legacy disturbances such as timber harvesting and underground coal mining?"

Little progress has been made toward answering these questions and fully understanding the hydrologic effects of surface mining and reclamation, especially in Central Appalachia. 


\section{$3 \quad$ Valley-Fill Designs using Geomorphic Landform Principles}

\subsection{Introduction and Objective}

Due to the ever-increasing demand for energy production, surface mining and reclamation has been the leading driver of land-use and land cover change in Central Appalachia for over fo5rty years (Townsend et al., 2009). Surface mining of coal in West Virginia has led to the production of approximately 50 million tons of coal per year through 2012 with over 40 million tons coming from mountaintop removal coal mining (WVOMHST, 2012). The coal produced in West Virginia is not only important to meet the increasing demand for the world's energy production, but is also vital to West Virginia's economy (WVOMHST, 2012).

Mountaintop removal surface mining involves the removal of overburden material to reach and remove coal seams beneath the soil surface. The spoil material is deposited in engineered valley fills which result in geotechnically stable structures but also result in the alteration of site hydrology including the burial of headwater stream channels. The filling of original stream channels with spoil material containing contaminants such as selenium and zinc results in altered stormflow response and long-term downstream detrimental impacts including elevated sedimentation, conductivity, and contaminant transport (Messinger, 2003; Hartman et al., 2005; USEPA, 2005; Negley and Eshleman, 2006; Lindberg et al., 2011; Griffith et al., 2012). These detrimental hydrologic impacts along with regulation stringencies have resulted in the dramatic reduction of surface mine and valley fill permits, thus resulting in coal mine closures, job loss, economic damage, and a push for reclamation design reform in Central Appalachia (FACES, 2015; WVOMHS\&T, 2015).

Companies are required by the Clean Water Act and related policies to mitigate stream and wetland impacts from fill activities either on site or nearby to minimize ecological impact (Palmer and Hondula, 2014). Compensatory off site mitigation is commonly used by companies to mitigate aquatic natural resources degraded or buried by surface mining practices (Palmer and Hondula, 2014). Mining companies often restore steams located on older, previously mined landscapes to satisfy mitigation requirements (Northington et al., 2011). This results in transferring the benefits of stream mitigation off site, as opposed to providing ecological benefits on the disturbed fill site. 
The objective of this research was to create alternative surface mine reclamation designs that allowed stream mitigation to be implemented on site for a permitted surface mine and valley fill site in Central Appalachia. An innovative reclamation technique, geomorphic landform design, was implemented to create alternative valley-fill designs for both new valley-fills and valley fills previously created using conventional techniques. This alternative reclamation technique has the ability to alter current reclamation techniques by creating stream channels on site as opposed to the current practice of mitigating buried streams off site. Hydrologic characteristics including stream length, drainage density, runoff patterns, and watershed configuration (stream channel patterns and topography) were compared among the undisturbed topography, conventional reclamation design, and geomorphic reclamation designs of the study site to determine the long-term hydrologic benefits and drawbacks of the reclamation applications in Central Appalachia.

\subsection{Research Question and Objectives}

Surface mining in the coal mining regions of the Appalachians has impacted hundreds of headwater streams (Palmer et al., 2010; Bernhardt and Palmer, 2011). Large-scale surface mining and valley-fill activities degrade streams within the disturbed watershed as well as nearby streams (Griffith et al., 2012; Palmer and Hondula, 2014). Stream mitigation is required; however, it is often completed off site, leaving the site hydrology unrestored (Northington et al., 2011; Palmer and Hondula, 2014). Therefore, a single research question was posed for this chapter:

- How can stream mitigation be implemented on surface mine valley-fill sites in Central Appalachia?

Two objectives were identified to answer the research question:

- Create a valley-fill reclamation design using geomorphic landform principles for a new valley fill using regional data inputs for on-site stream mitigation

- Create a valley-fill reclamation design using geomorphic landform principles for a valley fill previously constructed using conventional techniques

\subsection{Background: Valley-Fill Design using Geomorphic Landform Principles}

A previously created alternative valley-fill design, as described in Sears (2012), was designed for a permitted valley-fill site $\left(0.98 \mathrm{~km}^{2}\right)$ in southern West Virginia using geomorphic 
landform design principles based on the creation of mature, stable landforms (Figure 3.1). The software design tool Carlson ${ }^{\circledR}$ Natural Regrade ${ }^{\circledR}$ with GeoFluv ${ }^{\mathrm{TM}}$ was used. Default data inputs were used in this initial design due to lack of regional data necessary for a geomorphic landform design (GLD) that accurately mimicked the original landform features. The valley fill GLD resulted in sub-basins that directed flow to created stream channels (main channel and 12 tributaries) as opposed to control structures and Surface Water Run-Off Analysis (SWROA) ditches, typical of conventional valley-fill designs. The designed stream channels $(5,466 \mathrm{~m}$ total combined length; 131-1,440 m channel length range) were designed to mimic the original dendritic drainage (Sears et al., 2014). The elevation of the main valley channel ranged from 338 $\mathrm{m}$ to $608 \mathrm{~m}$ with a slope of $12.7 \%$. Proposed features of the design described by Sears (2012) included complex slope profiles (concave to convex), improved hydrology and groundwater movement, decreased infiltration and contaminant desorption, and decreased flooding risk. However, the created GLD required improvement including regional data inputs to accurately mimic the undisturbed topography, landform features, and channel pattern. 


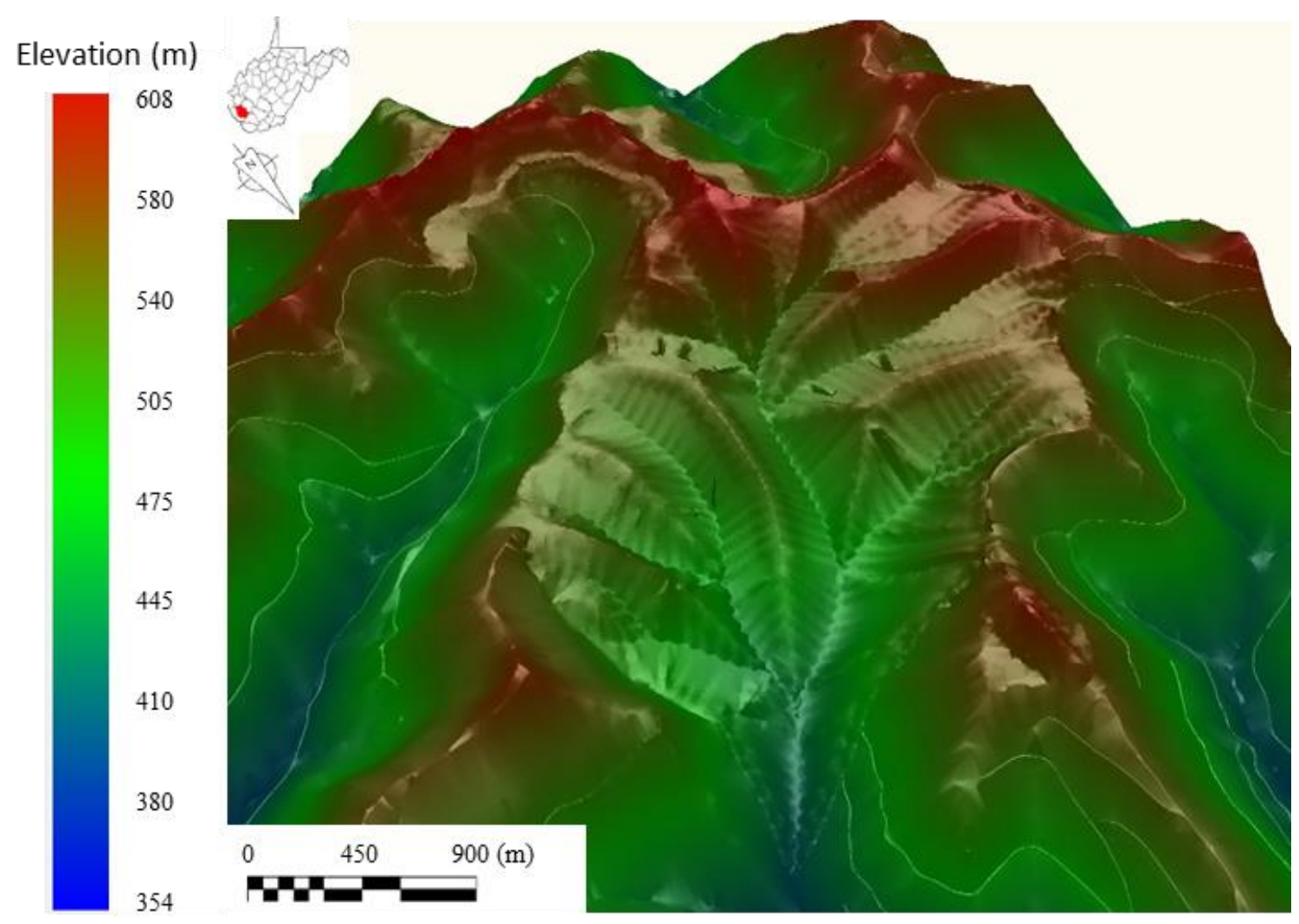

Figure 3.1. Geomorphic landform design of experimental watershed and surrounding area in Logan County, WV, created using default design inputs

\subsection{Methods}

\subsubsection{Study Site Description}

The study site was located in Logan County, West Virginia, USA and was in the Central Appalachian ecoregion (USEPA, 2013). Average precipitation was $1.18 \mathrm{~m}$ and the average annual temperature was $56^{\circ} \mathrm{F}$ for the study site (US Climate Data, 2014). The undisturbed topography (Figure 3.2) consisted of steep, complex (concave-convex) slope profiles with slopes reaching up to $27.5 \%$. The hydrology was composed of one main perennial channel with four contributing tributaries in a dendritic drainage pattern. The tributaries likely ranged from ephemeral to intermittent. The elevation of the main channel ranged from $338 \mathrm{~m}$ to $482 \mathrm{~m}$ with a slope was $10.1 \%$. The geology was dominated by sandstone (Russell, 2012) and the pre-mining vegetation was predominately dense core forest with a dominant land use of forestland (Figure 3.3). The experimental area also had sections of grassland/pastureland and the surrounding area had extensive mining disturbance and reclamation (Figure 3.3). 


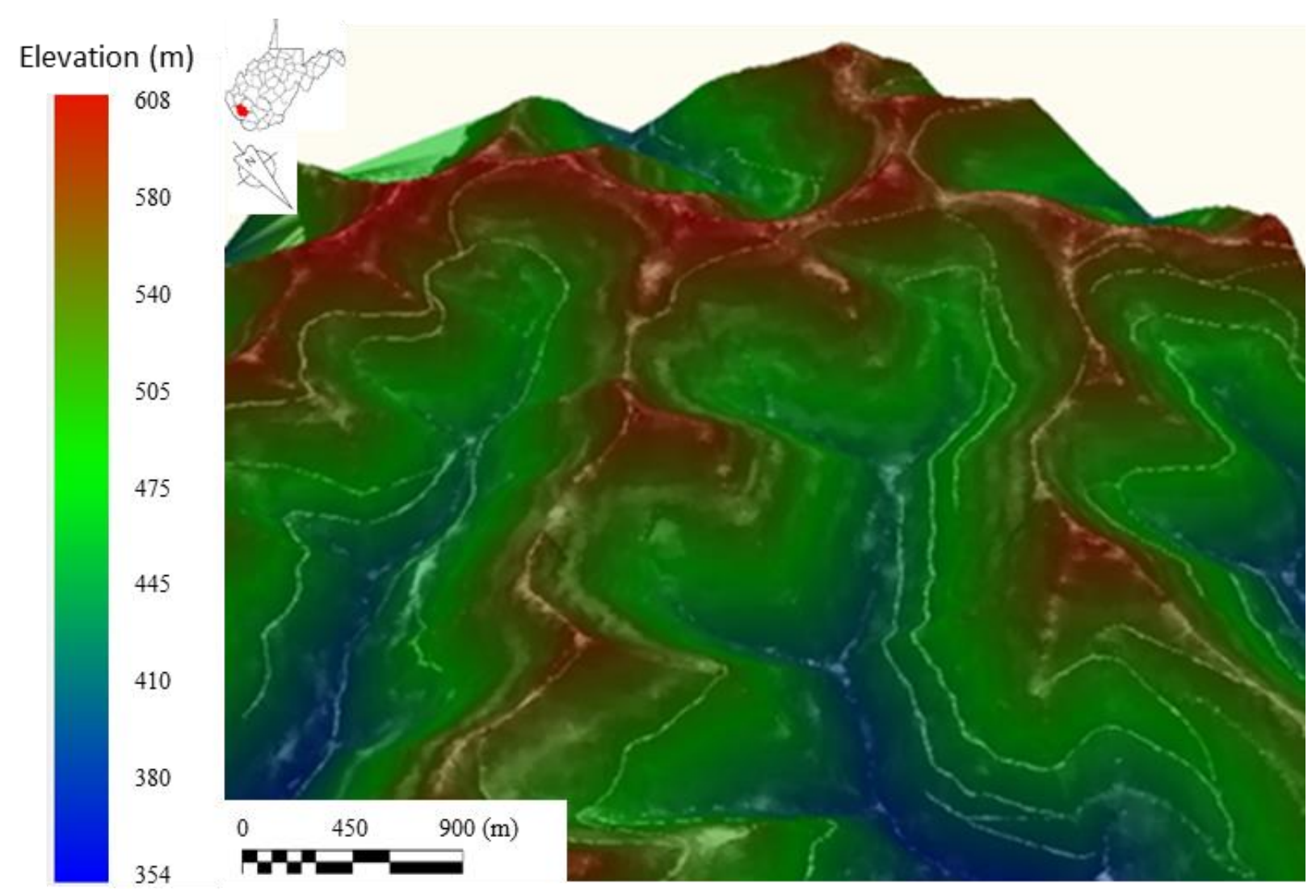

Figure 3.2. Original topography of experimental watershed and surrounding area in Logan County, WV 


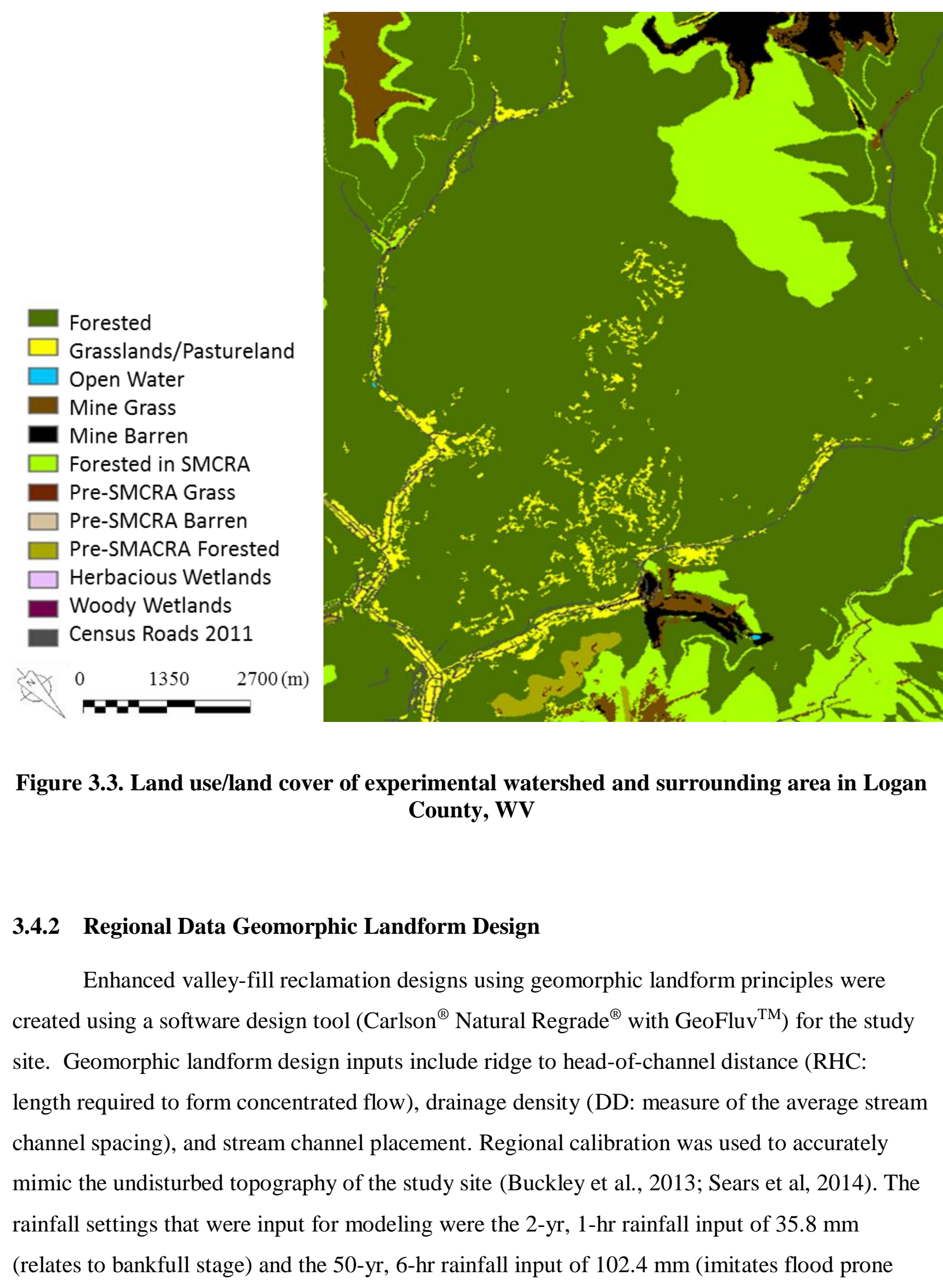


stage), which were obtained within the design tool Natural Regrade. Regional data obtained by Buckley et al. (2013) were used as the GLD inputs in this project and included a DD range of 5.3 $\pm 20 \% \mathrm{~km}^{-1}$ and a maximum RHC of 163-220 m. The previously created valley-fill design described in Sears (2012) was created using default inputs, which included a DD range of $7.5 \pm 20 \% \mathrm{~km}^{-1}$ and a RHC of $24 \mathrm{~m}$, but did not accurately imitate the undisturbed topography. The stream channels of the regional data GLD were designed to mimic the original dendritic drainage, which is typical for unconsolidated materials (Toy and Chuse 2005; Eckels and Bugosh 2010). Fluvial geomorphic principles were then applied to create four complete geomorphic landform designs: i) GLD, ii) Retrofit, iii) GLD with bench ponds, and iv) GLD with valley ponds.

The GLD applied geomorphic landform principles following the above method to create an alternative valley-fill design for the main subwatershed $\left(0.98 \mathrm{~km}^{2}\right)$ of the study site. The three additional enhanced designs were created to improve the conventional design or further enhance the GLD created using regional data. The retrofit design applied geomorphic landform principles to the surface of the conventional valley fill $\left(1.38 \mathrm{~km}^{2}\right)$ at the site to improve hydrology on the valley-fill crest by creating stream channels on the fill surface. The bench pond design added surface water retention structures to the regional data GLD $\left(0.98 \mathrm{~km}^{2}\right)$ to potentially provide long-term water availability for wildlife and diverse vegetation on the site. The valley pond design included adding runoff retention structures to the stream channels of the regional data GLD $\left(0.98 \mathrm{~km}^{2}\right)$ for improved hydrology control and the potential of perennial streamflow on the site surface.

\subsubsection{Retrofit Design}

Traditionally, conventional valley fill crests are surrounded by SWROA ditches to capture surface runoff and navigate to National Pollutant Discharge Elimination System (NPDES) discharge points. Required stream mitigation is often completed off site due to the difficulty of creating stream channels on valley-fill sites (Palmer and Hondula, 2014; Hopkinson et al., 2015b). Implementation of geomorphic landform design on the crest of conventional valley fills could kept stream mitigation benefits on site. A retrofit valley-fill design was created for the experimental site to illustrate the ability to design channelized flow and implement mitigation on the conventional fill crest using geomorphic principles. 
The design tool used (Natural Regrade) required the elevation of the head of a created channel be higher than the elevation of the mouth of the same channel for proper drainage and concave-to-convex slope profile creation. Therefore, the study site $\left(1.38 \mathrm{~km}^{2}\right.$; slope $=1-2 \%$; crest elevation: $505-516 \mathrm{~m}$ ) had to be divided into sections (four sections; $0.20 \mathrm{~km}^{2}-0.32 \mathrm{~km}^{2}$ ), each becoming a separate subwatershed drainage basin design by adding increased elevation points around the headwater areas, to meet the head elevation requirements for design. The stream channels were designed to drain to existing NPDES permit points, one per drainage basin, surrounding the permit boundary to maintain a hydrologic balance and comply with regulations. Geomorphic landform principles were applied to each section, one at a time, to create a completed geomorphic landform design with stream channels in a dendritic drainage pattern for each section.

\subsubsection{Regional Data GLD with Bench Ponds}

The bench pond runoff retention structures were created on the regional data GLD to mimic natural riparian wetlands and enhance the aquatic and wildlife habitat of the study site. Three bench ponds were designed within the valley-fill area $\left(0.98 \mathrm{~km}^{2}\right)$ and locations were chosen to equally space the ponds throughout the area to maximize wildlife benefit. The bench ponds were designed using AutoCAD by creating a closed 2D polyline as the top of dam of a specified width, and then projecting inward to model the pond, and outward to model the slopes to match to the target surface. The bench pond structures mimicked wetlands, were designed adjacent to the created stream channels, received inflow from the stream (part of total stream flow), and discharged pond overflow back into the stream.

\subsubsection{Regional Data GLD with Valley Ponds}

The valley pond surface runoff retention structures were created to potentially provide perennial streamflow downstream of the structures. Three valley ponds were spaced over the $0.98 \mathrm{~km}^{2}$ area and were located on the stream channels. Locations of the ponds within the site were chosen based on ample stream length both upstream of the ponds and downstream of the ponds to an outlet or another pond. The structures retain surface water runoff traveling downstream in the channelized flow paths, creating ponds. Each pond was designed using AutoCAD by creating a 2D polyline on the created GLD for each valley pond location. The 2D 
polyline represented the crest of the dam crossing a low area in the topography. The dam was then projected inward and outward to model the sloped structure.

\subsection{Results}

\subsubsection{Regional Data Geomorphic Landform Design}

The alternative valley-fill design (Figure 3.4), created using regional data inputs, consisted of ridges, valleys, and stream channels that mimicked the undisturbed topography and was designed using geomorphic landform design principles. Instead of control structures and SWROA ditches, created sub-basins directed flow to stream channels (main channel and 12 tributaries) on the fill surface. Created stream channels (5,466 m total combined length; 1311,440 m channel length range) mimicked the pre-disturbed dendritic drainage pattern of the site. Main valley slope was $12.7 \%$ and the elevation ranged from $354 \mathrm{~m}$ to $608 \mathrm{~m}$. Overall resulting drainage density of the site was $5.6 \mathrm{~km}^{-1}$, within the target range of $5.3 \pm 20 \% \mathrm{~km}^{-1}$ as suggested by Sears et al. (2014), suggesting site hydrologic balance. Additionally, the drainage density of each individual channel $\left(4.2-5.9 \mathrm{~km}^{-1}\right)$ was within the targeted range, creating a purported balanced design with hydrologic equilibrium. 


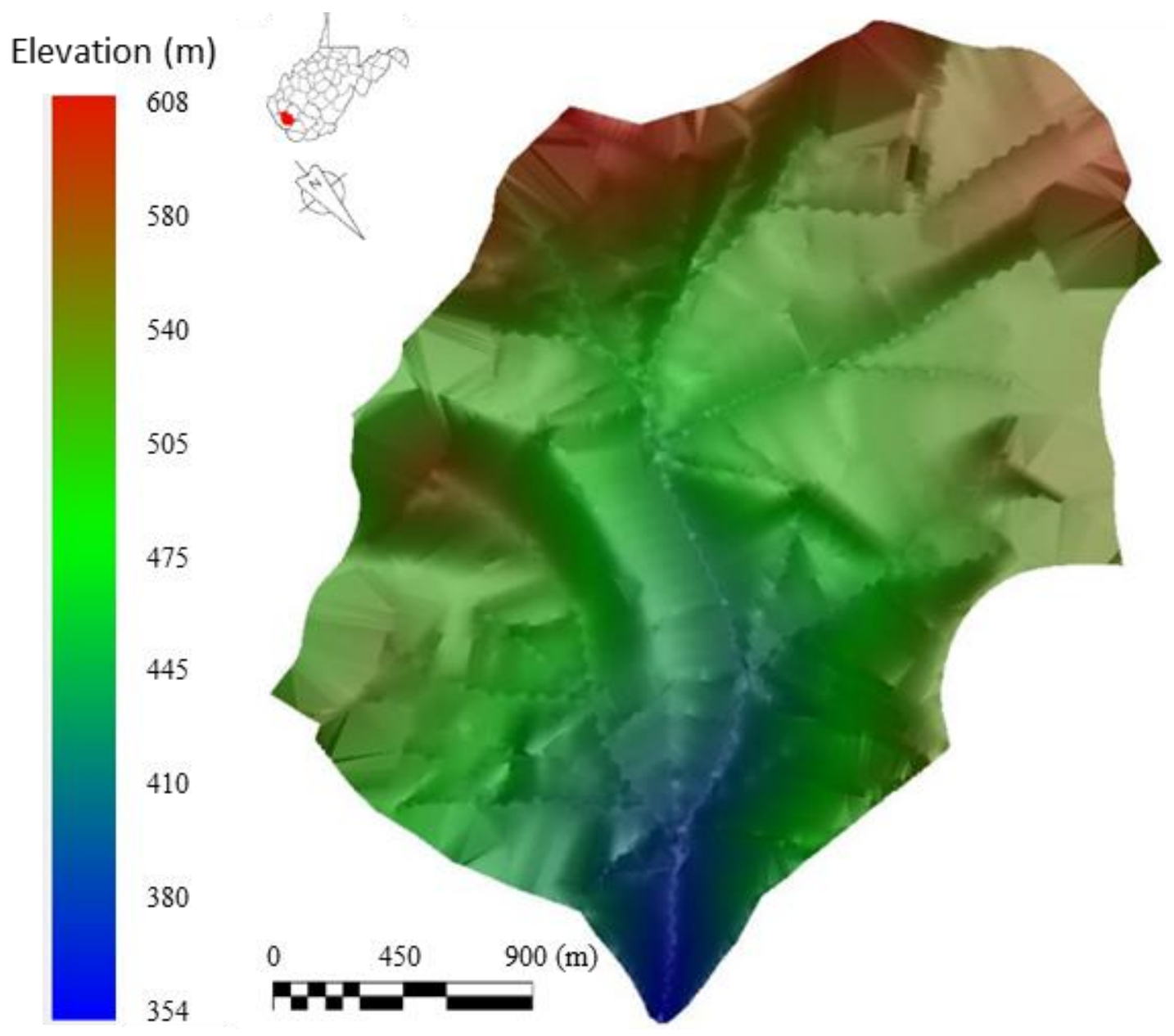

Figure 3.4. Geomorphic landform design of experimental watershed in Logan County, WV, created using regional data design inputs

\subsubsection{Retrofit Design}

The retrofit valley-fill design (Figure 3.5), created by applying geomorphic reclamation techniques to a conventional valley fill, resulted in stream channels, ridges, and valleys on the valley-fill crest previously flat (slope $=1-2 \%$ ). The conventional fill design prior to geomorphic reclamation did not include any drainage channels except SWROA ditches located around the perimeter of the fill crest. The retrofit design resulted in 8,345 $\mathrm{m}$ of stream length (124-927 m length range; Table 3.1) on the fill crest surface. Streams for each section were characterized by a main channel and tributary channels forming a dendritic drainage pattern and helped control drainage on the property through the channelization of runoff (Figure 3.5). All of the channels 
were checked to have a drainage density within the targeted default range of $6.0-9.0 \mathrm{~km}^{-1}$ and the retrofit design had an overall drainage density range of 7.1-8.9 $\mathrm{km}^{-1}$ (Table 3.1). Default design inputs were used for the retrofit design because the purpose of the design was to remove runoff from the surface faster and mitigate stream channels on site, not to mimic the original topography features. The design corresponded with government regulations (West Virginia Surface Mining Reclamation Regulations, Code of State Regulations §38) including no flow over valley-fill face and draining to NPDES points. A close-up of the GLD of section 1 (Figure 3.6) illustrated GLD features of complex (concave-convex) slope profiles, ridges, valleys, and stream channels. 


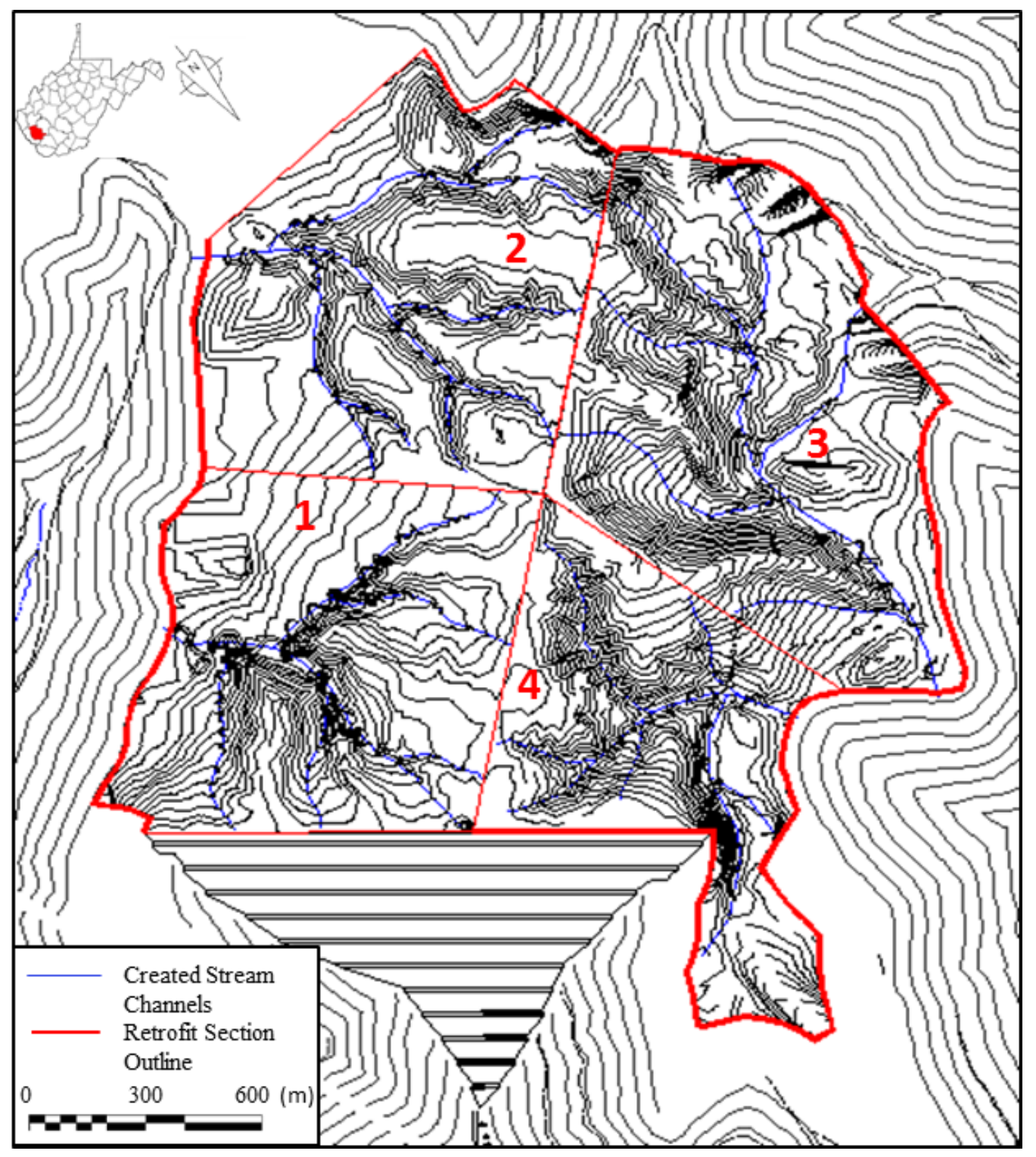

Figure 3.5. Retrofit design of experimental watershed in Logan County, WV, created with geomorphic landform design on conventional valley-fill crest $(1.5 \mathrm{~m}$ contours for design watersheds; $15.2 \mathrm{~m}$ contours surrounding area) 


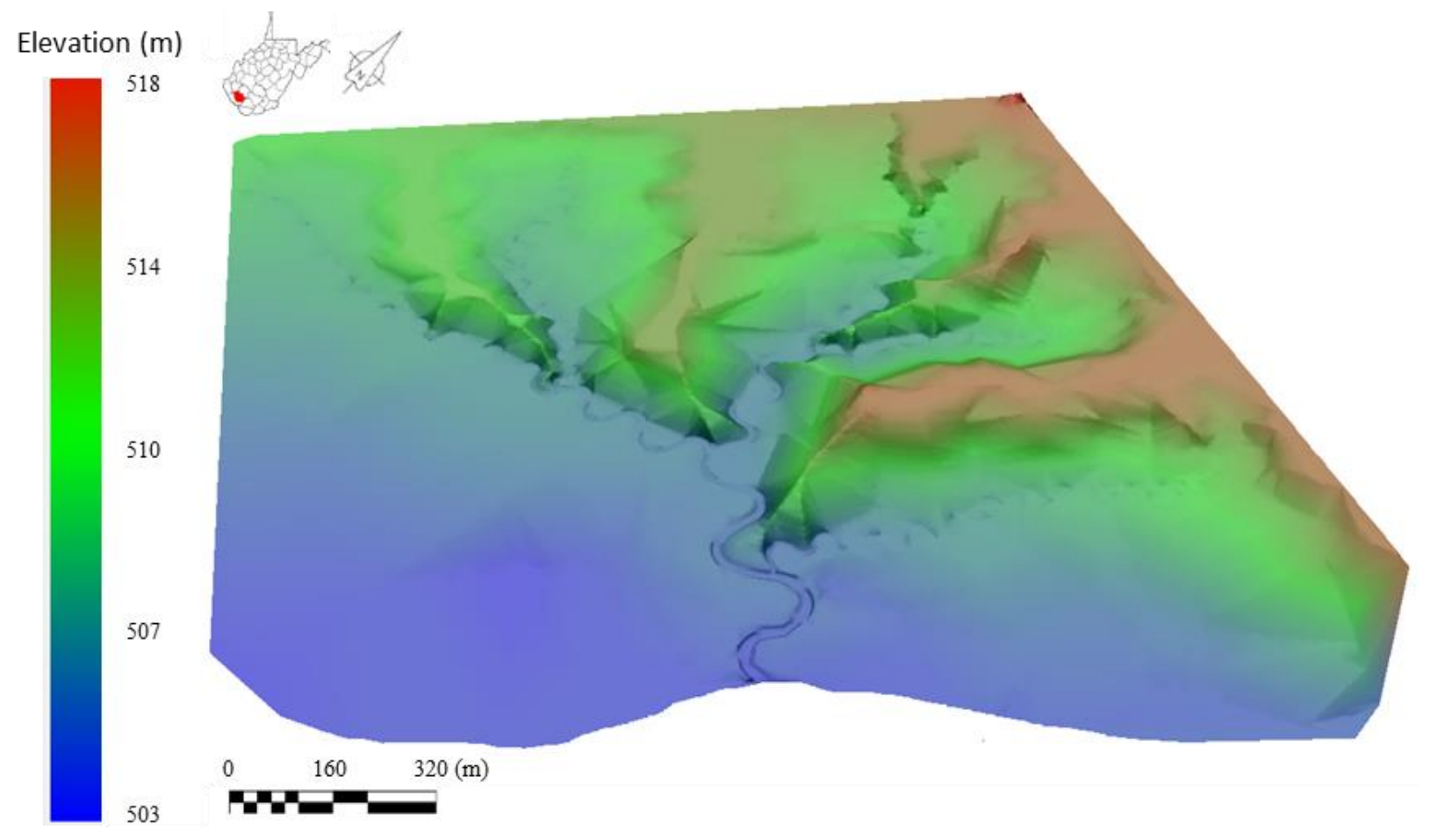

Figure 3.6. Close-up of section 1 of retrofit design of experimental watershed in Logan County, WV showing drainage pattern and topography

Table 3.1. Retrofit design specifications

\begin{tabular}{cccccc}
\hline Section & Area $\left(\mathbf{k m}^{\mathbf{2}}\right)$ & $\begin{array}{c}\text { \# of } \\
\text { Channels }\end{array}$ & $\begin{array}{c}\text { Total } \\
\text { Channel } \\
\text { Length }(\mathbf{k m})\end{array}$ & $\begin{array}{c}\text { Channel Length } \\
\text { Range }(\mathbf{m})\end{array}$ & $\begin{array}{c}\text { Drainage } \\
\text { Density }\left(\mathbf{k m}^{-\mathbf{1}}\right)\end{array}$ \\
\hline $\mathbf{1}$ & 0.26 & 6 & 1.9 & $137.5-552.2$ & 7.1 \\
$\mathbf{2}$ & 0.28 & 7 & 2.3 & $125.2-635.6$ & 8.0 \\
$\mathbf{3}$ & 0.32 & 6 & 2.4 & $266.6-927.2$ & 8.9 \\
$\mathbf{4}$ & 0.20 & 7 & 1.8 & $124.2-468.7$ & 7.6 \\
\hline
\end{tabular}

\subsubsection{Regional Data GLD with Bench Ponds}

The regional data geomorphic valley fill design with bench ponds was created by designing runoff retention structures on the fill surface (Figure 3.7). The three bench pond structures were designed to mimic natural and riparian wetlands and were located beside stream channels that were created on the valley-fill site. Three bench ponds were spaced over the 0.98 
$\mathrm{km}^{2}$ area and ranged in depth from $1.2 \mathrm{~m}$ to $4.4 \mathrm{~m}$ (Table 3.2). Pond depths were minimized to increase the probability of diverse vegetative species indicative of natural wetland habitats such as reed canary grass, three-square bulrush, sedges, and wild rice, which typically thrive in water depths up to $0.3 \mathrm{~m}$ (Interagency Core Group, 1998). Flow from the channels fill the ponds during storm events and sustain plant and animal life (Hunt, 1996; Interagency Core Group, 1998). Maximum pond storage for bench ponds 1,2 , and 3 were $12 \mathrm{~m}^{3}, 14 \mathrm{~m}^{3}$, and $28 \mathrm{~m}^{3}$ respectively (Table 3.2).

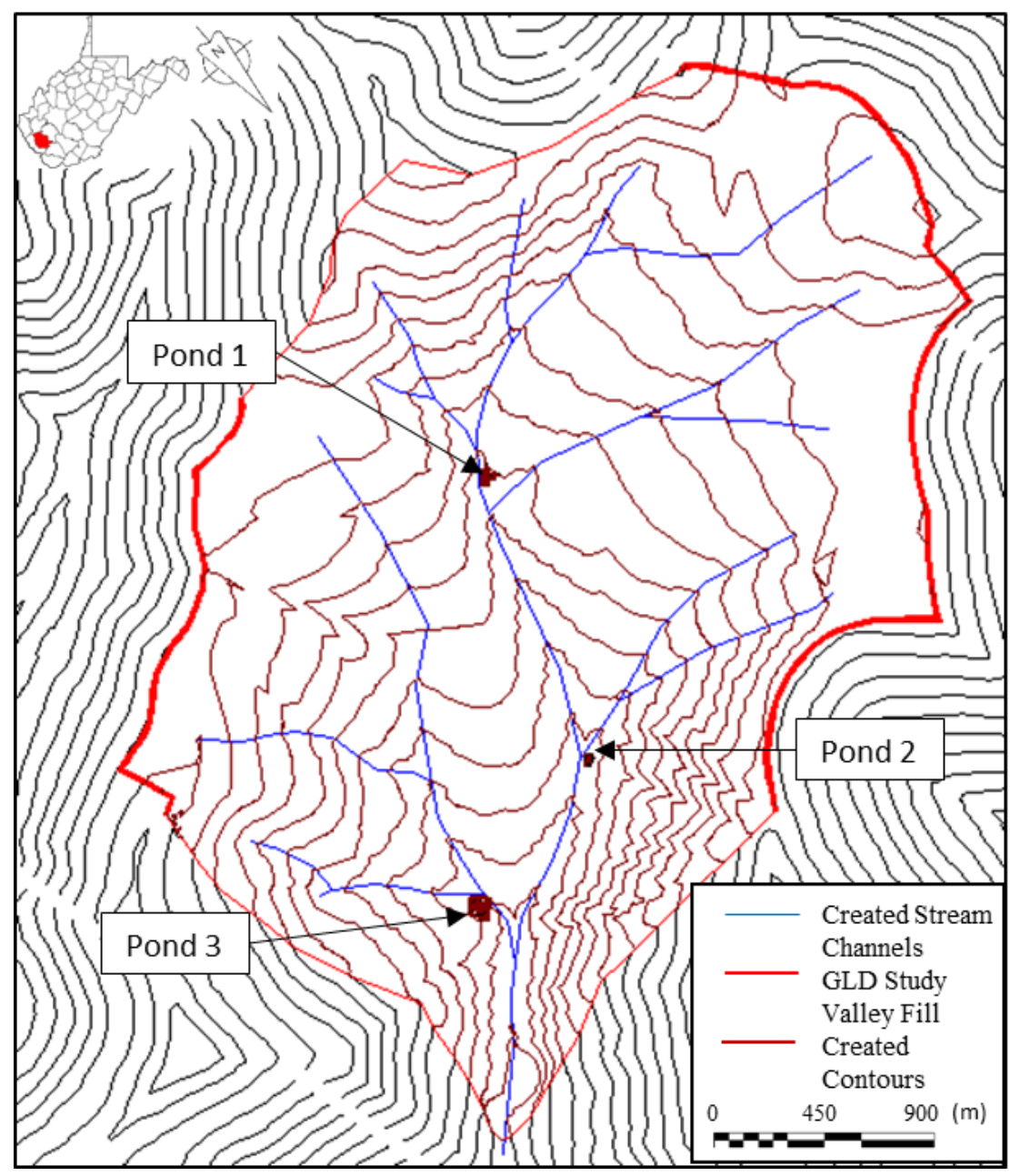

1 .

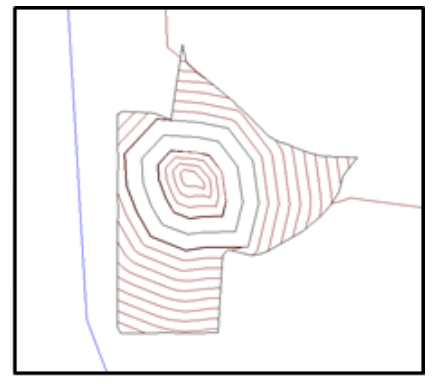

2.

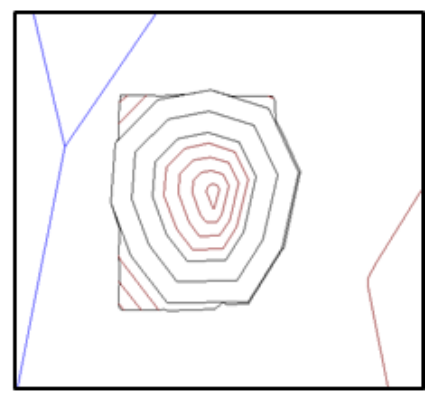

Figure 3.7. Geomorphic landform design with bench ponds of experimental watershed and surrounding area in Logan County, WV, created using regional design inputs (15.2 m contours for watershed; $0.3 \mathrm{~m}$ contours for ponds): A) bench pond 1; B) bench pond 2; and C) bench pond 3 
Table 3.2. Regional data GLD with bench ponds design specifications

\begin{tabular}{lccccc}
\hline & $\begin{array}{c}\text { Top of Dam } \\
\text { Elev. (m) }\end{array}$ & $\begin{array}{c}\text { Bottom of } \\
\text { Pond Elev. (m) }\end{array}$ & $\begin{array}{c}\text { Cut/Fill } \\
\text { Slope (\%) }\end{array}$ & $\begin{array}{c}\text { Pond Max. } \\
\text { Depth (m) }\end{array}$ & $\begin{array}{c}\text { Pond Storage at } \\
\left.\text { Max. Depth ( } \mathbf{m}^{\mathbf{3}}\right)\end{array}$ \\
\hline Bench Pond 1 & 455.1 & 453.9 & 30 & 1.2 & 12 \\
Bench Pond 2 & 396.2 & 394.9 & 30 & 1.3 & 14 \\
Bench Pond 3 & 380.8 & 376.4 & 30 & 4.4 & 280 \\
\hline
\end{tabular}

\subsubsection{Regional Data GLD with Valley Ponds}

The regional data geomorphic valley fill design with valley ponds was created by designing runoff retention structures on the fill surface (Figure 3.8). Three valley ponds were designed to illustrate that the creation of channelized streamflow and retention structures on the geomorphic fill with no groundwater connection, could potentially provide perennial streamflow on the site surface. The valley ponds were spaced over the $0.98 \mathrm{~km}^{2}$ area, with ample stream length both upstream $(0.93-2.4 \mathrm{~km})$ and downstream $(0.38-0.44 \mathrm{~km})$, and ranged in depth from 12.5-13.4 $\mathrm{m}$ (Table 3.3). The structures were designed to retain surface water runoff traveling downstream in the channelized flow paths, creating ponds. Each pond was designed to have a small storage area, as deep ponds would be a stability concern through buildup of pore-water pressure. Maximum pond storage for valley ponds 1,2 , and 3 were $1.1 \times 10^{4} \mathrm{~m}^{3}, 2.1 \times 10^{4} \mathrm{~m}^{3}$, and $1.6 \times 10^{4} \mathrm{~m}^{3}$ respectively (Table 3.3 ). 


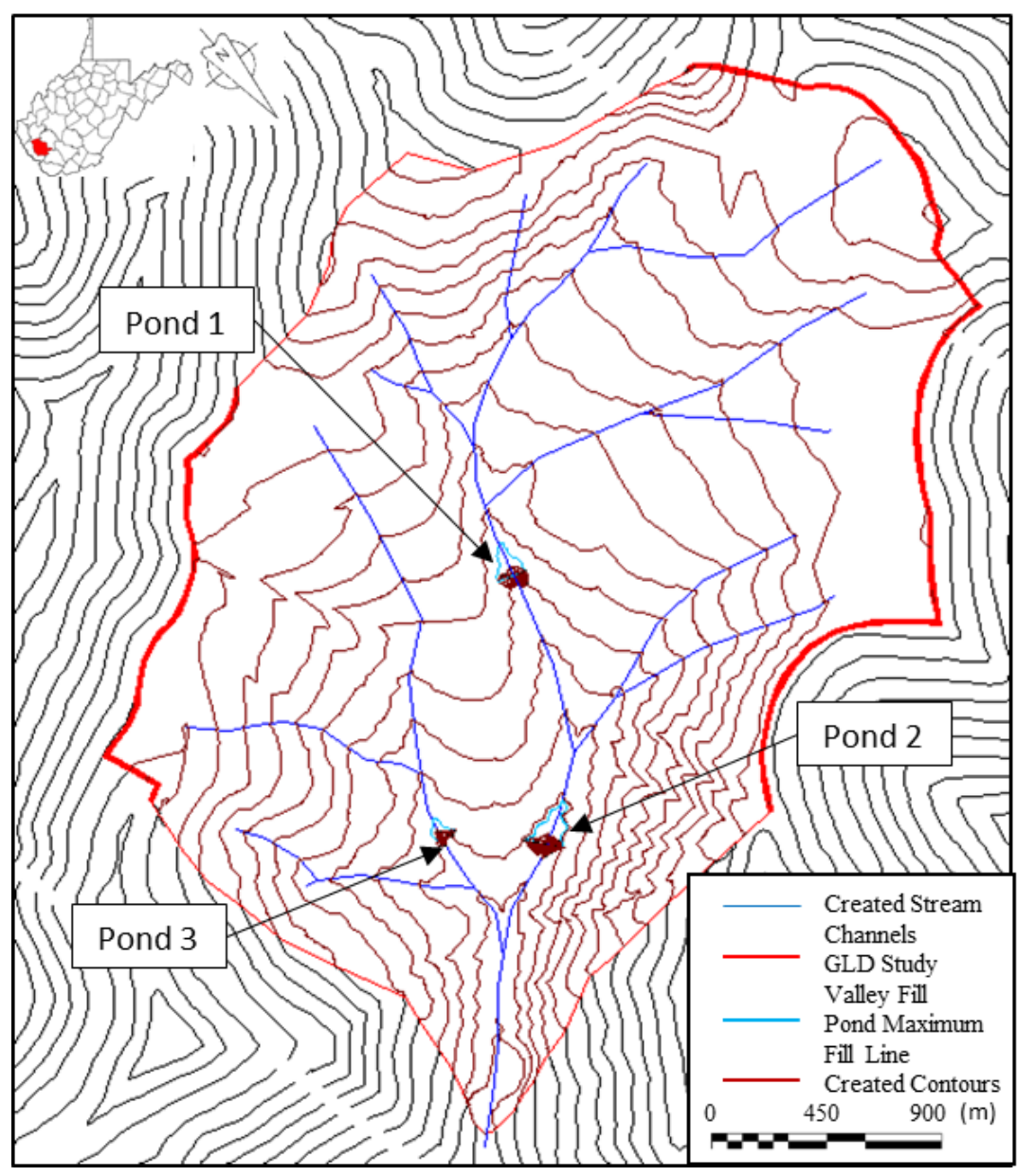

1.

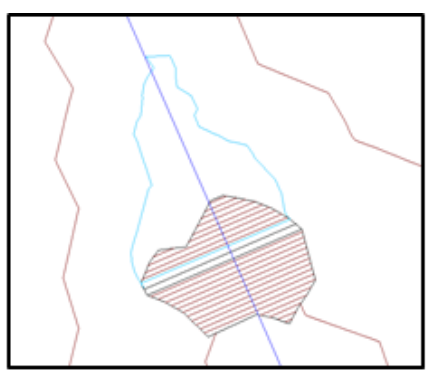

2.

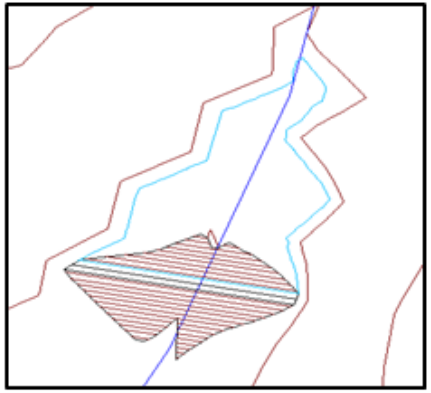

3.

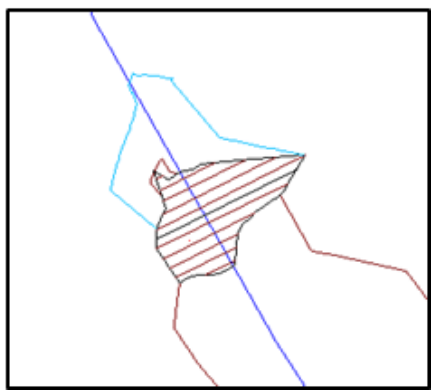

Figure 3.8. Geomorphic landform design with valley ponds of experimental watershed and surrounding area in Logan County, WV, created using regional design inputs $(15.2 \mathrm{~m}$ contours for watershed; $0.3 \mathrm{~m}$ contours for ponds): A) valley pond 1; B) valley pond 2; and C) valley pond 3 
Table 3.3. Regional data GLD with valley ponds design specifications

\begin{tabular}{cccc}
\hline & \multicolumn{3}{c}{ Valley Pond } \\
& $\mathbf{1}$ & $\mathbf{2}$ & $\mathbf{3}$ \\
\hline Top of Dam Elev. $(\mathbf{m})$ & 440.4 & 387.1 & 429.8 \\
Bottom of Dam Elev. $(\mathbf{m})$ & 427.9 & 374.3 & 416.4 \\
Upstream Slope Length $(\mathbf{k m})$ & 2.4 & 1.1 & 0.93 \\
Downstream Slope Length $(\mathbf{k m})$ & 0.38 & 0.42 & 0.44 \\
Cut/Fill Slope (\%) & 50 & 50 & 50 \\
Pond Max Depth (m) & 12.5 & 12.8 & 13.4 \\
Pond Storage at Max Depth $\left(\mathbf{m}^{\mathbf{3}}\right)$ & $1.1 \times 10^{4}$ & $2.1 \times 10^{4}$ & $1.6 \times 10^{4}$ \\
\hline
\end{tabular}

\subsubsection{Design Comparison}

All four GLDs provided enhanced alternatives to traditionally constructed valley fills. Features of the created designs include complex slope profiles and dendritic drainage patterns, potentially providing methods to implement stream mitigation on the fill site. Hydrologic characteristics including stream length, drainage density, runoff patterns, and watershed configuration (stream channel patterns and topography) of the four created designs and the conventional design were compared (Table 3.4).

The drainage density is the measure of the average stream channel spacing in the watershed. The regional data GLD, bench pond GLD, and valley pond GLD had an overall drainage density of $5.6 \mathrm{~km}^{-1}$, which was within the range $5.3 \pm 20 \% \mathrm{~km}^{-1}$ suggested by Sears et al. (2014) for regional inputs. Each stream channel had a drainage density $\left(4.2-5.9 \mathrm{~km}^{-1}\right)$ within the suggested range, which was important for site hydrologic balance and the minimization of soil erosion and aggradation. The stream channels for the retrofit design had drainage densities of $7.1 \mathrm{~km}^{-1}$ to $8.9 \mathrm{~km}^{-1}$, which were within the $6.0 \mathrm{~km}^{-1}$ to $9.0 \mathrm{~km}^{-1}$ default range. Default design inputs were used for the retrofit design to remove runoff from the surface faster and because the surface was not intended to imitate the original topography. The conventional valley-fill design did not have a calculated drainage density because the design included SWROA ditches along the perimeter of the fill crest as opposed to stream channels on site. 
The created drainage patterns of the regional data GLD, bench pond GLD, and valley pond GLD imitated the dendritic drainage pattern of the undisturbed watershed. The retrofit GLD drainage pattern was improved from the SWROA ditches along the perimeter of the fill crest to dendritic drainage patterns with the four created subwatersheds. The traditional valleyfill design filled the original dendritic drainage pattern surface and resulted in SWROA ditches along the perimeter of the fill crest (Table 3.4).

The GLDs (regional data, retrofit, bench pond, and valley pond) replaced the steep, rugged terrain with complex (concave-convex) slopes, while the conventional design resulted in a benched fill face (11 benches; 6.1-6.4 m wide every 15.2 vertical $\mathrm{m}$ in elevation) and slightly sloping (1-2\%) crest (WVDEP, 2011). The GLDs also resulted in increased stream channel length within the experimental watershed (regional data, bench pond, valley pond: 5,466 m; retrofit: $8345 \mathrm{~m})$ compared to the original stream length $(3,130 \mathrm{~m})$ of the site. The traditional valley-fill design did not include any stream channels on site except for the 3,109 m of perimeter SWROA ditches (Table 3.4).

The traditional valley-fill design, regional data GLD, bench pond GLD, and valley pond GLD each integrated $5.3 \times 10^{7} \mathrm{~m}^{3}$ of fill material, which included the $4.4 \times 10^{7} \mathrm{~m}^{3}$ of cut material after a swell factor of 1.2 (Sears et al., 2013) was applied. The retrofit design included $1.5 \times 10^{7}$ $\mathrm{m}^{3}$ of cut and fill material and the use of spoil material required no swell factor. The cut and fill volumes were balanced for the retrofit design so that no additional material would need acquired or disposed (Table 3.4). 
Table 3.4. Comparison of Traditional and GLD (Regional, Retrofit, Bench Pond, and Valley Pond) Parameters

\begin{tabular}{|c|c|c|c|c|c|}
\hline & Traditional & Regional Data & Retrofit & Bench Pond & Valley Pond \\
\hline Drainage density range, $\mathrm{km}^{-1}$ & N/A & $4.2-5.9$ & $7.1-8.9$ & $4.2-5.9$ & $4.2-5.9$ \\
\hline Drainage density overall, $\mathbf{k m}^{-1}$ & N/A & 5.6 & N/A & 5.6 & 5.6 \\
\hline Base surface drainage pattern & Dendritic & Dendritic & SWROA & Dendritic & Dendritic \\
\hline Designed drainage pattern & $\begin{array}{l}\text { Perimeter } \\
\text { SWROA } \\
\text { Ditches }\end{array}$ & Dendritic & Dendritic & Dendritic & Dendritic \\
\hline Base surface topography & Steep/Rugged & Steep/Rugged & Steep/Rugged & Steep/Rugged & Steep/Rugged \\
\hline Designed topography & $\begin{array}{l}\text { Benched face/ } \\
\text { Level top }\end{array}$ & $\begin{array}{l}\text { Complex } \\
\text { slopes }\end{array}$ & $\begin{array}{l}\text { Complex } \\
\text { slopes }\end{array}$ & $\begin{array}{l}\text { Complex } \\
\text { slopes }\end{array}$ & $\begin{array}{l}\text { Complex } \\
\text { slopes }\end{array}$ \\
\hline Water retention structure type & $\begin{array}{l}\text { SWROA/ } \\
\text { Toe Ponds }\end{array}$ & N/A & N/A & Bench ponds & Valley ponds \\
\hline Original stream length, $m$ & 3,130 & 3,130 & $3,109 *$ & 3,130 & 3,130 \\
\hline Created stream length, $m$ & N/A & 5,466 & 8,345 & 5,466 & 5,466 \\
\hline Created stream length range, $m$ & N/A & $131-1,440$ & $124-927$ & $131-1,440$ & $131-1,440$ \\
\hline Created Rosgen channel type & N/A & $\mathrm{A}, \mathrm{C}$ & $\mathrm{A}, \mathrm{C}$ & $\mathrm{A}, \mathrm{C}$ & $\mathrm{A}, \mathrm{C}$ \\
\hline Cut volume, $\mathbf{m}^{3}\left(\mathrm{yd}^{3}\right)$ & $\begin{array}{l}4.4 \times 10^{7} \\
\left(5.7 \times 10^{7}\right)\end{array}$ & $\begin{array}{l}4.4 \times 10^{7} \\
\left(5.7 \times 10^{7}\right)\end{array}$ & $\begin{array}{l}1.5 \times 10^{7} \\
\left(2.0 \times 10^{7}\right)\end{array}$ & $\begin{array}{l}4.4 \times 10^{7} \\
\left(5.7 \times 10^{7}\right)\end{array}$ & $\begin{array}{l}4.4 \times 10^{7} \\
\left(5.7 \times 10^{7}\right)\end{array}$ \\
\hline Fill volume, $\mathbf{m}^{3}\left(\mathbf{y d}^{3}\right)$ & $\begin{array}{l}5.3 \times 10^{7 * *} \\
\left(6.9 \times 10^{7}\right)^{* *}\end{array}$ & $\begin{array}{l}5.3 \times 10^{7 * *} \\
\left(6.9 \times 10^{7}\right)^{* *}\end{array}$ & $\begin{array}{l}1.5 \times 10^{7} \\
\left(2.0 \times 10^{7}\right)\end{array}$ & $\begin{array}{l}5.3 \times 10^{7 * *} \\
\left(6.9 \times 10^{7}\right)^{* *}\end{array}$ & $\begin{array}{l}5.3 \times 10^{7 * *} \\
\left(6.9 \times 10^{7}\right)^{* *}\end{array}$ \\
\hline
\end{tabular}

Note: GLD $=$ Geomorphic Landform Design, SWROA = Surface Water Runoff Analysis ditches, N/A = Not Applicable *Original stream length was SWROA ditch length

**Fill volume calculated using a swell factor of 1.2

\subsection{Discussion}

Current valley-fill reclamation practices in Central Appalachia involve the creation of engineered structures for mine spoil, resulting in the burial of headwater streams as well as hydrologic impacts to waters on site and the surrounding area (Palmer et al., 2010; Bernhardt and Palmer, 2011; Griffith et al., 2012). Section 404 of the Clean Water Act requires that companies perform compensatory mitigation to offset impacts of mining and valley-fill construction activities. Compensatory mitigation activities are designed to restore ecological services in stream channels either on the disturbed site or at an offsite location (Bonham and Stephenson, 2004). The objective of this research was to create alternative surface mine reclamation designs that allowed stream mitigation to be implemented on site for a permitted surface mine and valley fill site in Central Appalachia. 
An innovative geomorphic reclamation technique was implemented to create the alternative valley-fill designs for both new valley-fills and valley fills previously created using conventional techniques. Four alternative valley-fill reclamation designs were created for the experimental site in Logan County, WV: i) GLD using region specific inputs; ii) retrofit design with geomorphic landforms on conventional valley-fill crest; iii) regional data GLD with bench ponds; and iv) regional data GLD with valley ponds.

The geomorphic landform reclamation approach, applied to each design, has the potential to alter current reclamation techniques and improve site hydrology by incorporating stream networks into valley-fill reclamation design. The creation of stream channels on reclaimed valley fills has not had widespread implementation due to complexity, steep terrain, varied longterm results, and stringent regulation framework (Michael et al., 2010; Hopkinson et al., 2015b). Often, original stream channels buried during valley-fill construction are mitigated in locations where no original streams were located, resulting in little to no hydrologic improvement to the original stream areas (Northington et al., 2011). The four geomorphic valley-fill designs allowed the creation of stream channels on site, thus adding ecological benefits back to the disturbed site as opposed to other offsite locations.

Design i illustrated a valley-fill reclamation alternative created using geomorphic landform principles and regional data inputs that consisted of ridges, valleys, and stream channels that mimicked the undisturbed topography of the Central Appalachian site. Hydrology of the site consisted of sub-basins that directed runoff to channels on the fill surface that mimicked the pre-disturbed dendritic drainage pattern, as opposed to hydrologic control structures and SWROA ditches that are typical of conventional valley-fill designs. The GLD resulted in 5,466 m of created stream channel length within the experimental watershed and each stream channel ranged in length from $131 \mathrm{~m}$ to $1,440 \mathrm{~m}$. Design i illustrated the ability to design a new valley fill using geomorphic landform principles that implemented stream mitigation on site through the addition of 13 channels to the design. However, future research on stream channel construction materials and methods would need to be completed for geomorphic reclamation designs prior to design implementation.

Design ii, the retrofit design, applied geomorphic landform principles to the surface of the conventional valley fill at the study site to show the application of geomorphic reclamation techniques and stream mitigation to conventional valley fills. This retrofit design illustrated the 
ability to implement stream mitigation to previously created valley fills, abandoned valley fills, and failing valley fills that require widespread restoration. The conventional valley-fill site hydrology was dramatically altered from no hydrologic structures except SWROA ditches along the perimeter of the fill crest and ponds at the toe of the fill to 26 stream channels $(8,345 \mathrm{~m}$ total added stream length) on top of the fill crest. In addition to the implementation of channelized flow paths on the crest, the retrofit design altered slopes on the conventional valley fill crest to closer resemble natural topography.

The reclamation process of applying geomorphic landform principles to valley fills constructed using conventional techniques could be a revolutionary way to improve pre-existing mined lands and valley fills with respect to the addition of on-site stream channels. Many areas surface mined prior to the implementation of the SMCRA in 1977 were not reclaimed and often result in abandoned and failing sites. West Virginia has extensive areas that were mined prior to SMCRA (Figure 3.94). The Office of Abandoned Mine Lands and Reclamation (AML\&R) was created in 1981 to manage the reclamation of land and waters affected by mining prior to SMCRA. The retrofit design method illustrated a potential technique for the Office of AML\&R to improve the abandoned and failing surface mine sites. 


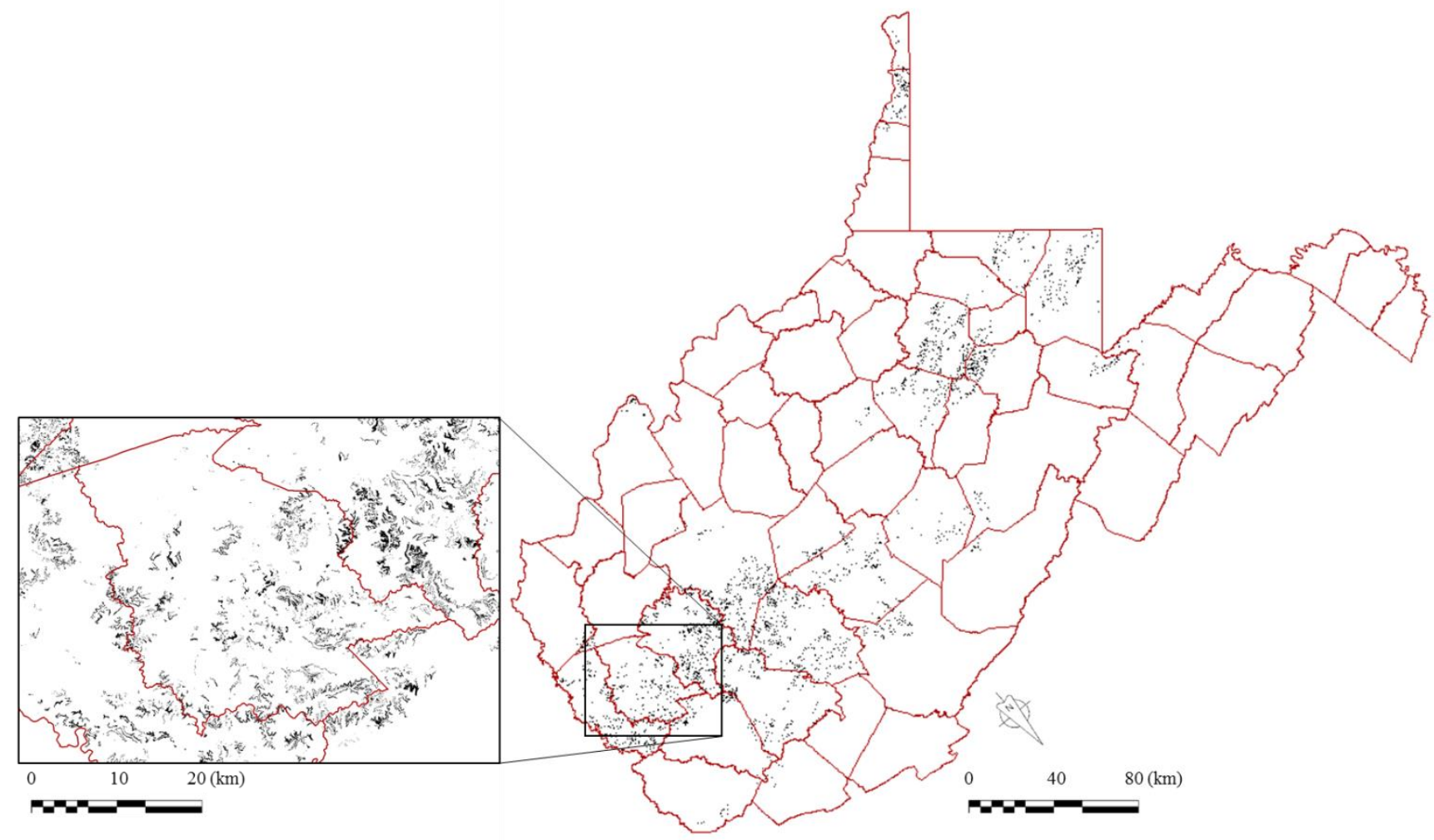

Figure 3.9. Pre-Surface Mining Control and Reclamation Act (SMCRA) mining activity areas in West Virginia and Logan County, WV (inset)

Designs iii and iv included surface storage on the regional data GLD fill, design i, in addition to the created stream channels and on-site mitigation. The bench pond design (iii) included retention structures on the fill with the purpose of mimicking natural wetlands and their hydrologic and ecological benefits. Three bench ponds were located adjacent to the created stream channels and included inflow from the stream to the pond and outflow from the pond back to the stream. Bench pond locations were chosen to equally space the ponds throughout the area to maximize wildlife and aquatic benefits. Streamflow to and from the ponds would occur mainly during storm events and could provide perennial pond water as well as diverse vegetation and wildlife nourishment. High quality stream and wetland habitat disturbed by mining and valley-fill activities could be mitigated by constructed riparian wetland habitat (Harms et al., 2010; Rahe et al., 2015). Creating the correct balance of water flow, water quality, and temperature in the pond could be challenging but could result in the natural benefits of wetlands, including erosion and flooding control, wildlife habitat, and contaminated water treatment, but would require future research on sizing and construction (Hunt, 1996; USEPA, 1999). 
The valley pond design (iv) was created by designing runoff retention structures on the regional data GLD fill surface with the purpose of illustrating that the addition of channelized streamflow and valley ponds on the geomorphic fill surface could potentially provide intermittent or perennial streamflow on valley fills with no groundwater connection. Three valley ponds were located on the created stream channels and were designed to have a small storage area, as deep ponds would be a stability concern through buildup of pore-water pressure. The valley pond design provided the opportunity for stream mitigation on site, diverse habitats for wildlife and vegetation, and potential long-term streamflow downstream of the ponds. However, further analysis of stream channel and pond design, including sizing and construction materials, would be necessary prior to design implementation.

This research illustrated the implementation of geomorphic landform reclamation in minefields in mountainous terrain. Each of the four designs demonstrated the ability to implement stream mitigation on site for both new and completed valley fills. Three of the designs (ii, iii, and iv) illustrated additional application sites, abandoned and failing sites, as well as runoff retention structure design for potential long-term stream flow and high-quality habitat on site. These alternative reclamation designs illustrate the potential for improvement needed for the approval of future surface mine and valley-fill permits in Central Appalachia as well as other mountainous terrain. 


\section{Soil Erosion Estimation using Revised Universal Soil Loss Equation (RUSLE) and Geographic Information System (GIS)}

\subsection{Introduction}

Soil erosion is a complex, dynamic process that includes detachment and transportation of surface soil across Earth's surface (Demirci and Karaburun, 2012). Soil erosion can occur by many means, including wind and water, with water being the main erosional force acting in Central Appalachia. Land use change, especially surface mining and valley-fill construction, increases the possibility of soil erosion and surface runoff due to the removal of vegetation, movement of burden material, excessively compacted soils, and prolonged soil exposure prior to re-vegetation (Warner et al, 2009; Hoomehr et al., 2015). Changes in erosion could lead to longterm changes in the shaping of the landscape and the sediment load in nearby bodies of water (Chen et al., 2011). Rill and gully development and the inability of vegetation to establish are signs of water erosion and are of particular concern on mine reclamation sites in Central Appalachia due to the steep, complex topography of the sites and changes in soil characteristics (Carroll et al., 2000; Yao et al., 2008; Berger et al., 2010). Rill growth typically stabilizes once vegetation, typically grass, has been re-established (Hoomehr et al., 2015); however, long-term erosion and impacts can continue to occur on the reclamation sites.

The detrimental impacts of soil erosion on soil degradation, hydrology, and water quality have been identified as causing long-term economic and environmental damages (Chen et al., 2011). Erosion and degradation can lead to decreased land productivity, decreased slope stability of impacted landforms, and increased sedimentation and suspended solids in downstream channels (Fernandez et al., 2003). Soil transported by erosion can carry nutrients and contaminants into streams, bodies of water, and groundwater resources (Kouli et al., 2009). This issue can be particularly important for reclamation sites with contaminant rich soils.

Regulations require surface mine reclamation to minimize erosion on disturbed sites. Effective control of erosion is often achieved with effective landform design management, surface soil cover and established vegetation, which are essential components of successful mining reclamation practices (Nicolau, 2002; Toy and Chuse, 2005; Martin-Moreno et al., 2013). Improving reclamation approaches on surface coal mining sites in steep, mountainous regions is necessary to reduce environmental impacts from extreme soil erosion (Carroll et al., 2000; 
Nicolau, 2002; Espigares et al., 2011). Proper understanding of both erosion rates and spatial distribution is needed to accurately manage surface mine sites that have been reclaimed using different reclamation practices. However, no research has been documented on modeling predicted soil loss of valley-fill reclamation sites in Central Appalachia.

\subsection{Research Question and Objectives}

Better understanding of soil loss rates and spatial distribution within a watershed altered by surface mining and reclamation would be beneficial for the improvement of future erosion, reclamation methods, and conservation practices in Central Appalachia (Fernandez et al., 2003; Fu et al., 2005). Therefore, a single research question was posed for this chapter:

- How is soil loss altered at the watershed scale by different valley-fill reclamation methods?

Two objectives were identified to answer the research question:

- Predict average annual soil loss rates for multiple valley-fill reclamation practices

- Estimate the spatial distribution of erosion for multiple valley-fill reclamation conditions

\subsection{Background: Sediment Load using Revised Universal Soil Loss Equation (RUSLE) in a GIS Framework}

The Revised Universal Soil Loss Equation (RUSLE) is a set of mathematical equations that estimate average annual soil loss. RUSLE is a practical and prevalent tool used for many applications, including surface mining reclamation plans and post-reclamation site evaluations (Toy et al., 1999). RUSLE estimates average annual soil loss by sheet and rill erosion, not concentrated flow, on the portions of landscape profiles where erosion is occurring (Renard et al., 1991) using the empirical equation:

$$
A=R * K * L S * C * P
$$

where $A$ is the average soil loss per unit area during a unit period of time, $R$ is the rainfall-runoff erosivity factor, $K$ is the soil erodibility factor, $L S$ is the slope length and steepness factor, $C$ is the cover-management factor and $P$ is the supporting practices factor (Renard et al., 1991). 
GIS and remote sensing tools have been used effectively in cooperation with RUSLE to predict soil loss (Demirci and Karaburun, 2012). GIS provides an analysis of individual factors such as soil type, slope, and land use, all of which contribute to soil erosion, and is beneficial when used with RUSLE to estimate soil erosion at the watershed level (Demirci and Karaburun, 2012).

\subsection{Methods}

The Revised Universal Soil Loss Equation (RUSLE) was utilized in a distributed GIS framework to assess erosion and estimate the spatial soil loss for each of five design scenarios: i.) undisturbed, pre-mining condition; ii.) conventional valley fill post-mining, pre-revegetation condition; iii.) conventional valley fill post-reclamation, long term condition; iv.) GLD postmining, pre-revegetation condition; v.) GLD post-reclamation, long term condition. The values of the factors were determined from the soil survey, topography, meteorological data, land cover, land use, and literature pertaining to the study watershed and surrounding area, as detailed in the following sections. The spatial distribution of erosion rates within the experimental watershed were quantified using RUSLE in a GIS environment following the methods of Chen et al. (2011) and Demirci and Karaburun (2012).

\subsubsection{Study Site}

The study site was located in Logan County, West Virginia, USA and undisturbed topography consisted of steep, complex slope profiles with slopes reaching up to $27.5 \%$ (Figure 4.1A). Elevation of the site ranged from $338 \mathrm{~m}$ to $608 \mathrm{~m}$ and the slope gradient ranged from $0.5 \%$ to $205.7 \%$ (Figure 4.2A). The area was in the Central Appalachian ecoregion (USEPA, 2013) with an average annual temperature of $13^{\circ} \mathrm{C}$ and average precipitation of $1.18 \mathrm{~m}$ (US Climate Data, 2014). The pre-mining watershed hydrology included one main perennial channel with four contributing tributaries likely ranging from ephemeral to intermittent (Buckley et al., 2013). The main valley slope was $10.1 \%$ and the pre-mining vegetation was predominately dense core forest with a dominant land use of forestland. The geology of the site was dominated by sandstone (Russell, 2012). 


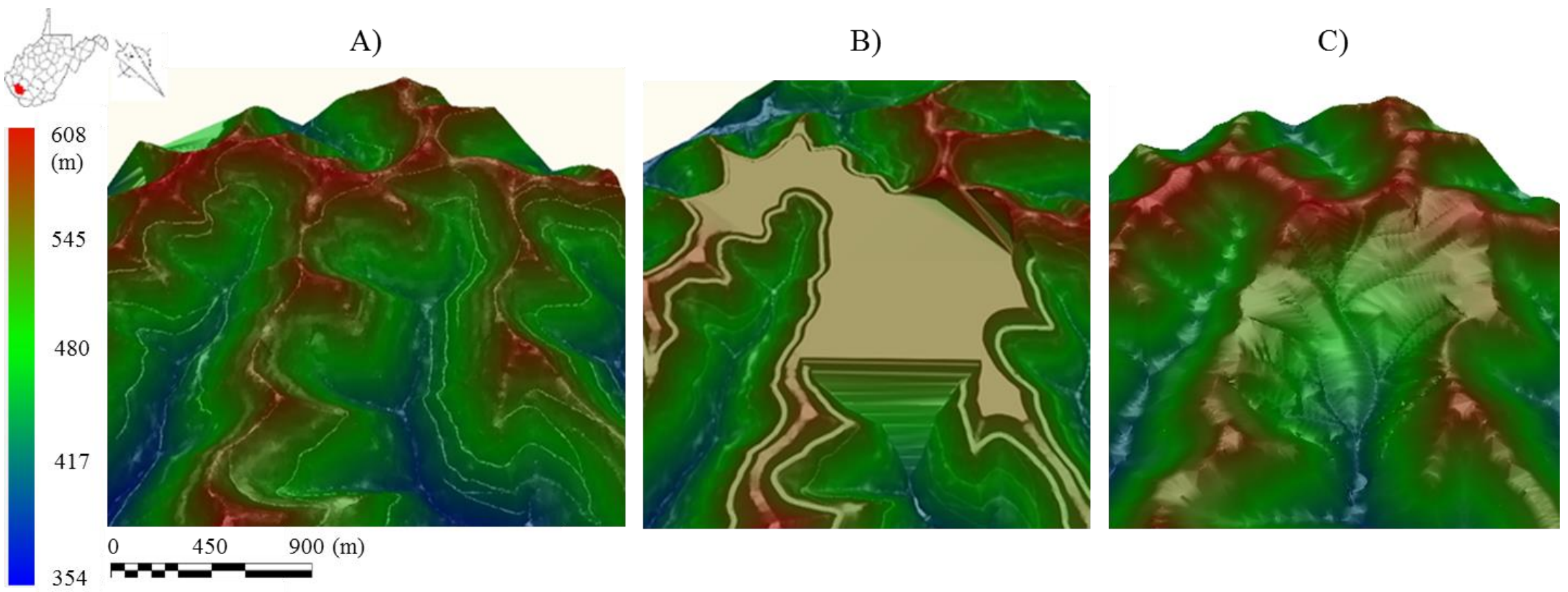

Figure 4.1. a) Original topography of experimental watershed in Logan County, WV, b) completed conventional valley-fill design for experimental watershed, c) completed geomorphic landform design using regional data inputs for experimental watershed 

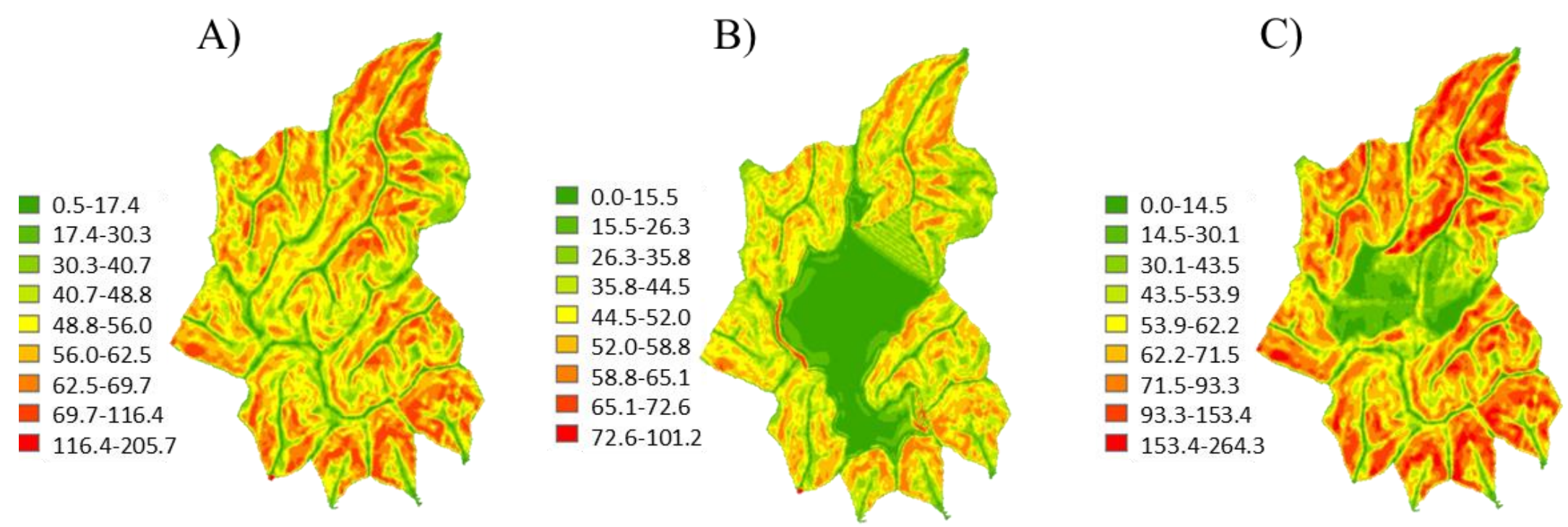

Figure 4.2. Slope (\%) of the experimental watershed: a) original topography, b) completed conventional valley-fill, c) completed geomorphic landform design 


\subsubsection{Conventional Valley Fill}

The permitted valley-fill design $\left(1.4 \mathrm{~km}^{2} ; 6.9 \times 10^{6} \mathrm{~m}^{3}\right.$ fill material $)$ for the site consists of conventional valley-fill features including a benched valley fill face (11 benches: 6.1-6.4 $\mathrm{m}$ wide every 15.2 vertical meters in elevation), rock core underdrain, and Surface Water Runoff Analysis (SWROA) ditches located around the perimeter of the fill (Figure 4.1B). Elevation of the site ranged from $338 \mathrm{~m}$ to $608 \mathrm{~m}$ and slope ranged from $0.1 \%$ to $101.2 \%$ (Figure $4.2 \mathrm{~B}$ ). The top of the fill was reclaimed to a planar surface that sloped away from the fill face (1-2\%) in accordance with an Approximate Original Contour (AOC) variance permit to support the postreclamation land use of pastureland. The pastureland (commercial cow-calf operation) was present in $65 \%$ of the fill area and was predominately reclaimed vegetation of grass. The remaining $35 \%$ of fill area was permitted to be reclaimed forestland. The conventional fill resulted in the burial of approximately 3,130 m of original stream length.

\subsubsection{Geomorphic Landform Design (GLD) Valley Fill}

An alternative valley-fill design based on geomorphic landform design (GLD) principles and included on-site stream channels, as described in Chapter 3 (Valley-Fill Designs using Geomorphic Landform Principles) and Sears et al. (2014), was created for the study site (0.98 $\mathrm{km}^{2}$ ) (Figure 4.1C). The software design tool (Carlson ${ }^{\circledR}$ Natural Regrade ${ }^{\circledR}$ with GeoFluv ${ }^{\mathrm{TM}}$ ) and regional data inputs (Sears et al., 2014; Buckley et al., 2013) were used for attempting the creation of mature, stable landforms. The GLD resulted in sub-basins that directed flow to stream channels (main channel and 12 tributaries) as opposed to the control structures and SWROA ditches in the conventional design. The stream channels (5,466 m total combined length; 1311,440 m length range; type A and type C (Rosgen, 1994)) were designed to mimic the original dendritic drainage (Sears et al., 2014). The elevation ranged from $338 \mathrm{~m}$ to $608 \mathrm{~m}$, the slope gradient ranged from $0 \%$ to $264.3 \%$ (Figure $4.2 \mathrm{C}$ ), and the main valley slope was $12.7 \%$.

\subsubsection{RUSLE Factor Determination Methods}

\subsubsection{Rainfall Erosivity Factor, $R$}

Rainfall erosivity is the intensity of the rainfall to cause erosional effects on the land. In RUSLE, the rainfall-runoff erosivity factor, $R$, represents the erosivity occurring from rainfall 
and runoff at a particular location (Renard et al., 1991; Demirci and Karaburun, 2012). In many studies, the $\mathrm{R}$ factor has been determined to be the most related to soil loss and erosion (Renard and Freimund, 1994; Yu and Rosewell, 1996; Kouli et al., 2009).

The $\mathrm{R}$ factor is typically calculated using long-term annual rainfall records as the sum of $\mathrm{EI}_{30}$ for each storm where $\mathrm{E}$ is the storm energy $\left(\mathrm{MJ} \mathrm{ha}^{-1} \mathrm{~mm}^{-1}\right)$ and $\mathrm{I}_{30}$ is the maximum 30 minute intensity $\left(\mathrm{mm} \mathrm{h}^{-1}\right)$. However, lack of storm energy and intensity data require the use of monthly and annual rainfall data to calculate $\mathrm{R}\left(\mathrm{MJ} \mathrm{mm} \mathrm{ha} \mathrm{m}^{-1} \mathrm{~h}^{-1} \mathrm{year}^{-1}\right)$. The value of the Rfactor was calculated from the collected rainfall data as well as the Modified Fournier's Index (MFI), a widely used parameter for rainfall erosivity (Arnoldus, 1980; Renard and Freimund, 1994; Demirci and Karaburun, 2012). MFI was calculated (Eq. 4.2) as the sum of the squared monthly precipitation divided by the annual precipitation (Renard and Freimund, 1994).

$$
M F I=\frac{\sum_{i=1}^{12} p_{i}^{2}}{P}
$$

where $p_{i}(\mathrm{~mm})$ is the average monthly precipitation and $P(\mathrm{~mm})$ is the average annual precipitation (Kouli et al., 2009; Arnoldus, 1980).

Hourly precipitation data from the nearest weather station (WV465353; Logan, WV; 19 km from study site) were used. Twenty-three years (1986-2009) of hourly rainfall data were collected and used for the calculation of MFI and $R$ (Figure 4.3). 


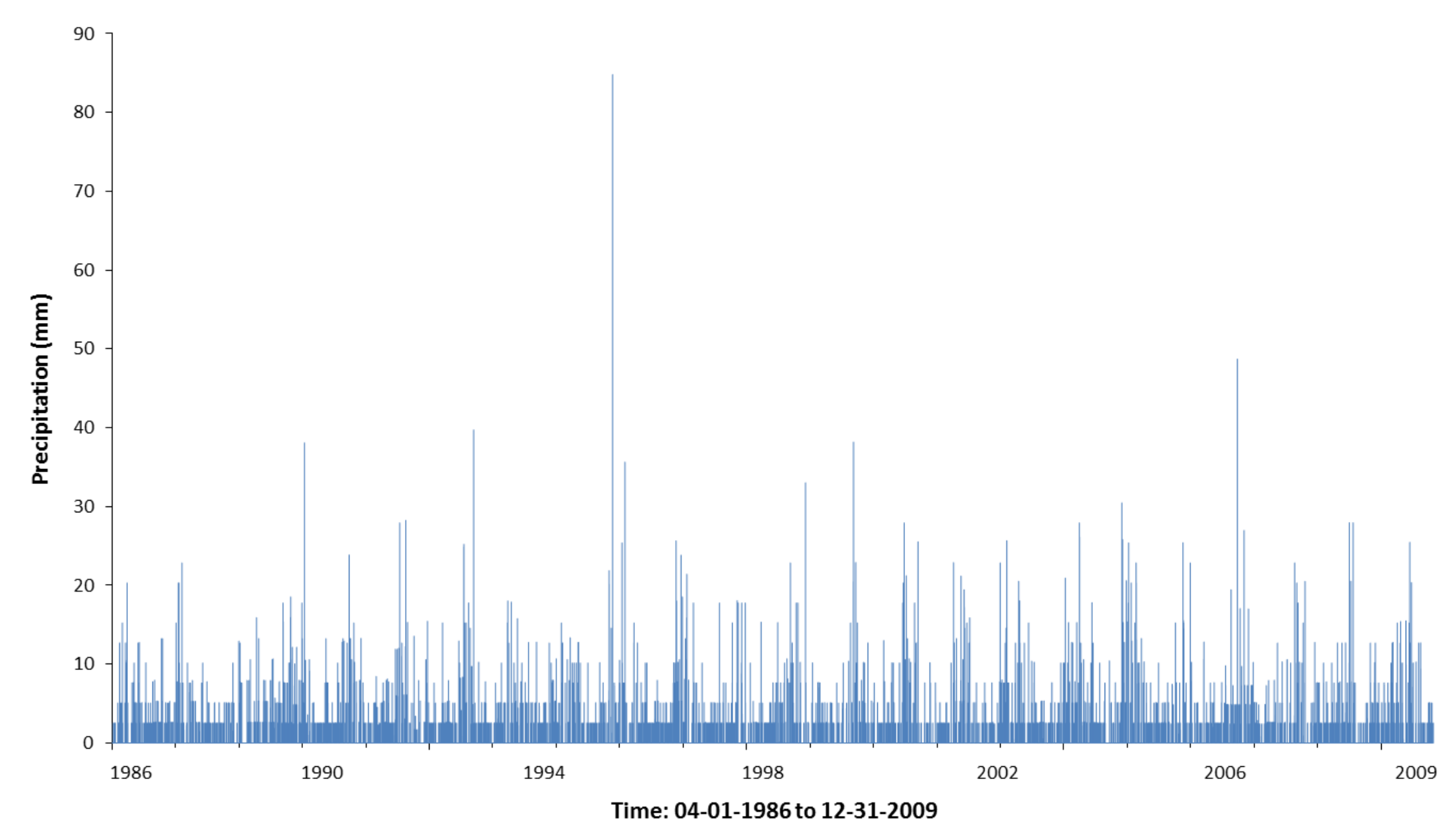

Figure 4.3. Hourly precipitation data from WV465353 meteorological station in Logan, WV 
Renard and Freimund (1994) proposed two equations for the calculation of the R-factor, using $P$ or MFI, in the continental United States based on data from 132 stations. First, the Rfactor was calculated using $P$ in Eq. 4.3 (Renard and Freimund, 1994).

$$
R=587.8-(1.219 * P)+\left(0.004105 * P^{2}\right)
$$

for $P>850 \mathrm{~mm}$, where $R\left(\mathrm{MJ} \mathrm{mm} \mathrm{ha}{ }^{-1} \mathrm{~h}^{-1}\right.$ year $\left.^{-1}\right)$ is the rainfall-erosivity factor and $P$ is the mean annual precipitation (mm). Then, the R-factor was calculated using MFI in Eq. 4.4 (Renard and Freimund, 1994).

$$
R=95.77-(6.081 * M F I)+\left(0.477 * M F I^{2}\right)
$$

for $P>850 \mathrm{~mm}$, where $R\left(\mathrm{MJ} \mathrm{mm} \mathrm{ha} \mathrm{m}^{-1} \mathrm{~h}^{-1}\right.$ year $\left.^{-1}\right)$ is the rainfall-erosivity factor and MFI is the Modified Fournier's Index (mm).

\subsubsection{Soil Erodibility Factor, $K$}

The soil erodibility factor, $\mathrm{K}$, represents the erodibility of the soil or surface material at the study location (Renard et al., 1991; Demirci and Karaburun, 2012). The K-factor is a quantitative value that is determined based on soil texture, structure, organic matter content, and permeability (Demirci and Karaburun, 2012; Kouli et al., 2009). The K-factor is calculated using the soil erodibility nomograph (Wischmeier and Smith, 1978). The soil erodibility nomograph solves Eq. 4.5 for soils containing less than $70 \%$ silt and very fine sand.

$$
100 K=2.1 M^{1.14}\left(10^{-4}\right)(12-a)+3.25(b-2)+2.5(c-3)
$$

where $a$ is the percent organic matter, $b$ is the soil structure code used in soil classification (1very fine granular; 2-fine granular; 3-medium or coarse granular; 4-blocky, platy, or massive), $c$ is the profile permeability class (1-rapid; 2-moderate to rapid; 3-moderate; 4-slow to moderate; 5-slow; 6-very slow), and $M$ is the particle size parameter defined as: 


$$
M=(s i+v f s) *(100-c l)
$$

where $s i$ is the percent of silt $(0.002-0.05 \mathrm{~mm}), v f s$ is the percent of very fine sand $(0.05-0.1$ $\mathrm{mm}$ ), and $c l$ is the percent clay ( $<0.002 \mathrm{~mm}$ ) (Wischmeier and Smith, 1978).

Soil properties of the undisturbed soil were estimated using the soil survey and literature. The undisturbed soil at the study site was classified as Matewan-Highsplint-Guyandotte in the soil survey with an estimated 35\% Matewan soil (channery sandy loam; 8-15\% clay; 35\% sandstone rock fragments), 30\% Highsplint soil (channery loam; <18\% clay; 50\% mixed rock fragments), and $20 \%$ Guyandotte soil (channery loam; $<15 \%$ clay; 55\% rock fragments) (NRCS, 2013; USDA, 2014). Percent sand and silt ranges (50\%-85\% and 0\%-50\% respectively) were obtained from the soil texture triangle for sandy loam and used in the nomograph calculation of the K-factor. An organic matter percentage, a, was estimated using literature findings of organic matter in undisturbed soil and spoil material (Evans and Loch, 1996; Warner et al., 2009). The soil structure code, $\mathrm{b}$, was determined by the dominate percentages (35\%-55\%) of rock fragments in the soils. The profile permeability class, $\mathrm{c}$, was determined from the soil survey and verified by relating the range of percent possible clay in the soil, from the soil texture triangle, to $\mathrm{c}$ (Chen et al., 2011).

Soil properties of the spoil were obtained from Russell (2012). The grain size distribution of the spoil (Russell, 2012) was used to obtain nomograph inputs including percent silt and very fine sand of $4 \%$, percent clay of $1 \%$, percent sand $(0.1-2.0 \mathrm{~mm})$ of $25 \%$. The spoil permeability $(0.0029 \mu \mathrm{m} / \mathrm{s})$ was also obtained from Russell (2012) and was correlated to c according to the USDA (1951) classification. The amount of organic matter (a) in the spoil was unknown and therefore was estimated using Evans and Loch (1996) for spoil material. The soil structure code was determined by relating the spoil organic matter to the soil structure (Chen et al., 2011) and was verified using Evans and Loch (1996).

\subsubsection{Slope Length and Steepness Factor, LS}

The overall topography contributes two factors to soil erosion in RUSLE including the length factor, L, and the steepness factor, S (Renard et al., 1997; Demirci and Karaburun, 2012). The LS-factor depends on slope percentage and length and is defined as a ratio of soil loss under given conditions to those at the study site (Demirci and Karaburun, 2012). The LS-factor was 
calculated in a GIS environment using separate equations for slope gradient <21\% (Eq. 4.7 as given in USLE) and for slope gradient $\geq 21 \%$ (Eq. 4.8 as incorporated in RUSLE) (Chen et al, 2011; Renard et al., 1997).

$$
\begin{gathered}
L S=\left(Q_{A c c} * \frac{X}{22.13}\right)^{m} *\left(65.41 * \sin ^{2} \theta+4.56 * \sin \theta+0.065\right) \\
L S=\left(Q_{A c c} * \frac{X}{22.13}\right)^{0.7} *\left(6.432 * \sin \left(\theta^{0.79}\right) * \cos \theta\right)
\end{gathered}
$$

where $Q_{A c c}$ was the grid layer of flow accumulation expressed as the number of grid cells, $X$ was the length of a cell side or cell resolution $(10.58 \mathrm{~m}), m$ is 0.5 if the percent slope was $5 \%-21 \%$, and $\theta$ was angle of the slope. The LS-factor was computed from the DEM of the study site in ArcGIS (Fernandez et al., 2003; Chen et al., 2011).

\subsubsection{Cover and Management Factor, $\mathrm{C}$}

The cover and management factor represents the effects of management practices and ground cover on the soil erosion rate (Demirci and Karaburun, 2012). Values for the C-factor range from near zero for a very well protected soil to 1.5 for a finely tilled, ridged surface that produces large amounts of runoff and leaves the soil highly susceptible to rill erosion (Renard et al., 1991). Values for the C-factor are a weighted average of soil loss ratios (SLRs) that represent the soil loss for a given condition at a given time and vary throughout the year as soil and land cover change (Renard et al., 1991). In RUSLE, SLRs are computed as a function of four subfactors: prior land use, canopy, ground cover, and within-soil effects (Renard et al., 1991; Wischmeier and Smith, 1978). The C-factor was determined by matching the vegetative cover, type, and percent ground cover of the study area with the $\mathrm{C}$-factor values in the Wischmeier and Smith (1978) C-factor determination tables.

\subsubsection{Supporting Practices Factor, $P$}

The supporting practices factor, $\mathrm{P}$, represents how surface conditions affect flow paths and flow hydraulics (Renard et al., 1991). The P-factor values were determined by the extent of individual conservation practices including contouring, strip cropping, and terracing or a combination of these (Fernandez et al., 2003). Implemented conservation practices typically 
decreased the erosive impact of rainfall and runoff and therefore were accounted for in the Pfactor (Renard et al., 1997; Fernandez et al., 2003).

\subsubsection{Methods and Inputs of Modeled Conditions}

\subsubsection{Undisturbed, Pre-Mining Condition Methods}

The R-factor remained constant over the entire study area for every condition because the rainfall data was collected from a single meteorological station located closest to the study watershed (Figure 4.4; Table 4.1). The rainfall data were assumed to be similar throughout the entire study area and remain unchanged during the five study conditions. The R-factor was calculated using the calculated MFI of $116.9 \mathrm{~mm}$, resulted in a value of 5,906.9 $\mathrm{MJ} \mathrm{mm} \mathrm{ha}{ }^{-1} \mathrm{~h}^{-1}$ $\mathrm{yr}^{-1}$. The R-factor of 5,906.9 MJ mm ha-1 $\mathrm{h}^{-1} \mathrm{yr}^{-1}$ was implemented because of the extended, accepted use of MFI to calculate R-factor values in published literature (Renard and Freimund, 1993; Yu and Rosewell, 1996). This R-factor was used for each condition for the entire study area.

Land cover and canopy cover were estimated from valley-fill field studies in Central Appalachia (Hopkinson et al., 2014a). A C-factor of 0.003 was estimated assuming $70 \%$ of area covered by canopy of trees and undergrowth and $80 \%$ of area covered by duff at least two inches deep. No supporting practices were implemented within the study site; therefore, the P-factor was equal to one for this study for all modeling scenarios. The organic matter $(a)$ was $1.5 \%$ for undisturbed Central Appalachian soils. The soil structure code (b) was 4 (blocky, platy, or massive) according to the dominate percentages (35-55\%) of rock fragments in the soils. The profile permeability class $(c)$ was 2 (moderate to rapid). Using the nomograph method and the soil property inputs, the K-factor was calculated as 0.22 for the undisturbed soil.

The LS-factor varied over the study area with a spatial mean value of 9.1 and a standard deviation of 17.1. Low LS values (minimum value of 0 ) occurred mainly along ridgelines. High LS-factors (maximum value of 424.3) were located at stream channel locations (Figure 4.4). 

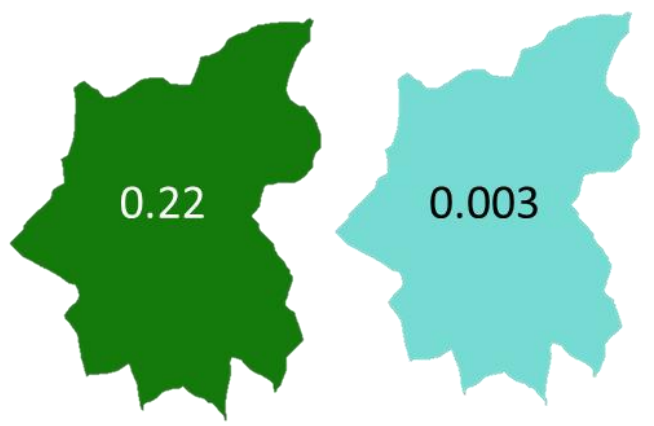

K-Factor

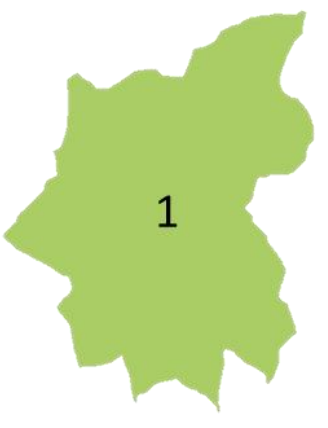

P-Factor
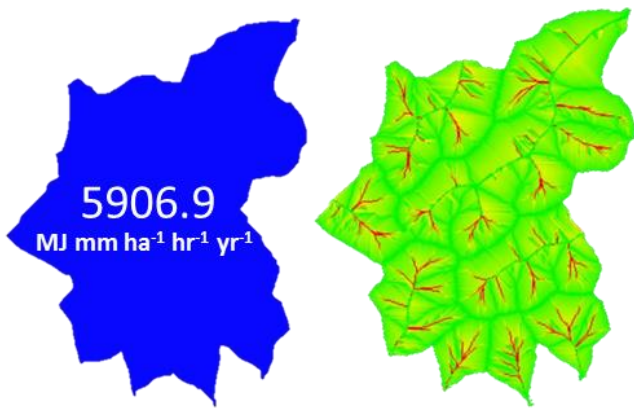

High : 424 .

Low: 0

LS-Factor

Figure 4.4. RUSLE input factors used for the undisturbed, pre-mining condition of the experimental watershed

Table 4.1. RUSLE input factors for each modeled condition of the experimental watershed

\begin{tabular}{|c|c|c|c|c|c|c|c|}
\hline \multirow[b]{2}{*}{ Condition } & \multirow{2}{*}{$\begin{array}{c}\mathbf{R} \\
\text { [MJ mm ha-1 } \\
\text { h-1 year-1] }\end{array}$} & \multirow{2}{*}{$\begin{array}{l}\text { C } \\
{[-]}\end{array}$} & \multirow{2}{*}{$\begin{array}{l}\mathbf{P} \\
{[-]}\end{array}$} & \multirow{2}{*}{$\begin{array}{l}\mathbf{K} \\
{[-]}\end{array}$} & \multicolumn{3}{|c|}{ LS [-] } \\
\hline & & & & & Range & Mean & $\begin{array}{l}\text { Std. } \\
\text { Dev. }\end{array}$ \\
\hline $\begin{array}{l}\text { Undisturbed, Pre- } \\
\text { Mining }\end{array}$ & 5906.9 & 0.003 & 1 & 0.22 & $0-424.3$ & 9.1 & 17.1 \\
\hline $\begin{array}{l}\text { Conventional Valley Fill } \\
\text { Post Mining, Pre- } \\
\text { Vegetation }\end{array}$ & 5906.9 & $\begin{array}{c}0.003 \\
0.12\end{array}$ & 1 & $\begin{array}{l}0.16 \\
0.22\end{array}$ & $0-487.7$ & 7.8 & 18.7 \\
\hline $\begin{array}{c}\text { Conventional Valley Fill } \\
\text { Post Reclamation, Long } \\
\text { Term }\end{array}$ & 5906.9 & $\begin{array}{l}0.003 \\
0.012 \\
0.038\end{array}$ & 1 & $\begin{array}{l}0.16 \\
0.22\end{array}$ & $0-487.7$ & 7.8 & 18.7 \\
\hline $\begin{array}{l}\text { GLD Post-Mining, Pre- } \\
\text { Vegetation }\end{array}$ & 5906.9 & $\begin{array}{c}0.003 \\
0.12\end{array}$ & 1 & $\begin{array}{l}0.16 \\
0.22\end{array}$ & $0-409.4$ & 9.7 & 18.1 \\
\hline $\begin{array}{l}\text { GLD Post-Reclamation, } \\
\text { Long Term }\end{array}$ & 5906.9 & $\begin{array}{c}0.003 \\
0.12\end{array}$ & 1 & $\begin{array}{l}0.16 \\
0.22\end{array}$ & $0-409.4$ & 9.7 & 18.1 \\
\hline
\end{tabular}




\subsubsection{Conventional Valley Fill Post-Mining, Pre-Vegetation Condition Methods}

The K-factor was a single value for all of the reclaimed conditions (conventional and GLD) due to the same spoil (predominately weathered sandstone) used for each scenario. The $\mathrm{K}$-factor for all of the undisturbed, surrounding area also remained a single value $(0.22)$ for each of the scenarios (Figure 4.5). The spoil organic matter (a) was $0.5 \%$ and the soil structure code (b) was 4 (blocky, platy, or massive). Spoil permeability (c) was 6 (very slow) due to soil properties, compaction, and rock fragments. The particle size parameter $(M)$ was calculated to be 396. Using these inputs, the K-factor was calculated (Eq. 4.5) to be 0.16 (Figure 4.5; Table 4.1), which coincided with the K-factor range published by Evans and Loch (1996).

A C-factor of 0.12 was determined using the straw or hay mulching rate of 1.5 tons/acre (WVDEP, 2011). The $\mathrm{C}$-factor for the undisturbed area surrounding the disturbed land was given the same value (0.003) as the undisturbed forest determined in 4.4.10 (Undisturbed, Pre-Mining Condition Methods).

The LS-factor varied over the study area with a mean value of 7.8 and a standard deviation of 18.7. Low LS values (minimum value of 0 ) occurred mainly along ridgelines. High LS-factors (maximum value of 487.8) were located at stream channel locations and valley-fill face (Figure 4.5).

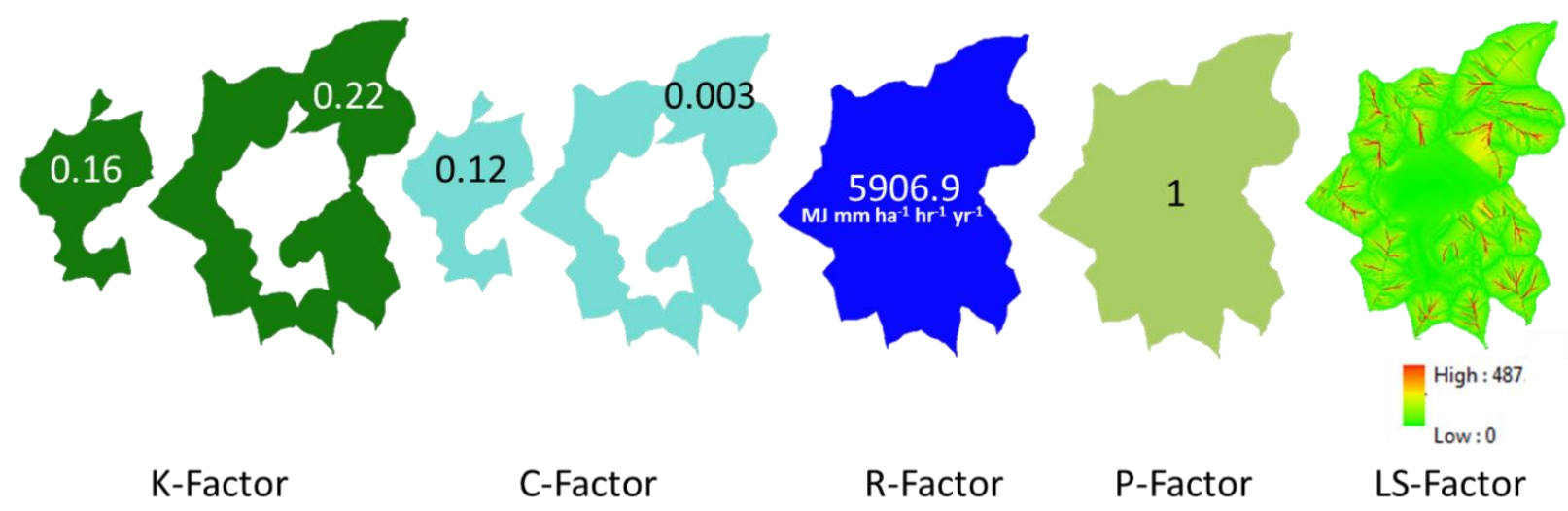

Figure 4.5. RUSLE input factors used for the conventional valley fill, pre-vegetation condition of the experimental watershed 


\subsubsection{Conventional Valley Fill Post-Reclamation, Long Term Condition Methods}

The $\mathrm{C}$-factor for the pastureland (65\% of reclaimed area) was estimated to be 0.038 using vegetative canopy of $25 \%$ cover of tall weeds or short brush with average drop fall height of 20 in and 60\% type $\mathrm{G}$ (cover at surface is grass, grasslike plants, decaying compacted duff, or liter at least 2 in deep) ground cover as described in Hopkinson et al. (2014a) (Figure 4.6; Table 4.1). A C-factor value of 0.012 was estimated for the reclaimed forest land (35\% of reclaimed area) using vegetative canopy of 50\% appreciable brush or bushes with average drop fall height of 6.5 $\mathrm{ft}$ and $80 \%$ type $\mathrm{G}$ ground cover as described in Hopkinson et al. (2014a). The C-factor for the undisturbed area surrounding the reclaimed land was given the same value (0.003) as the undisturbed forest determined in 4.4.10 (Undisturbed, Pre-Mining Condition Methods).

The LS-factor varied over the study area with a mean value of 7.8 and a standard deviation of 18.7. Low LS values (minimum value of 0 ) occurred mainly along ridgelines. High LS-factors (maximum value of 487.8) were located at stream channel locations and valley-fill face (Figure 4.6).

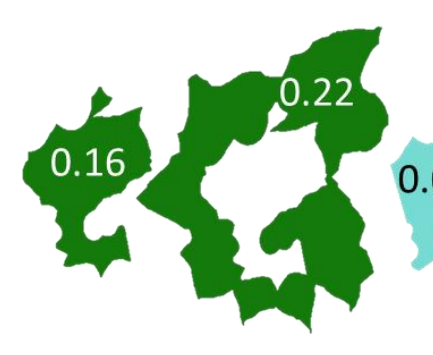

K-Factor

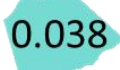

0.012

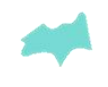

C-Factor

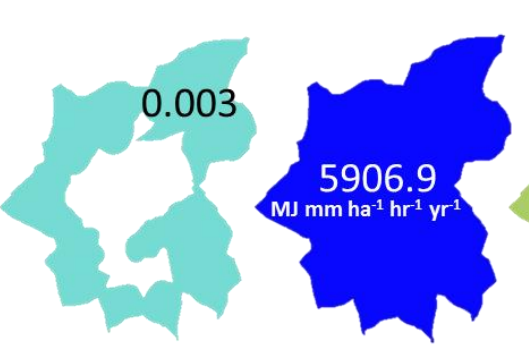

R-Factor
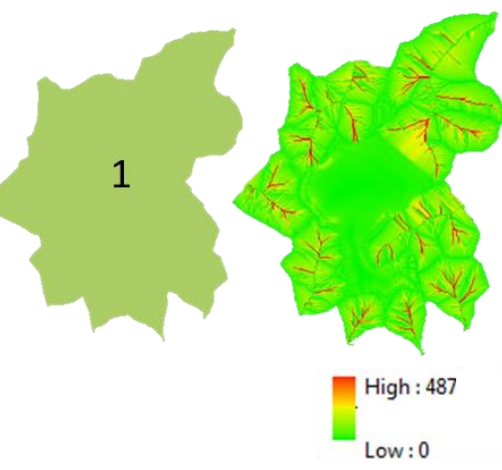

P-Factor

\section{Figure 4.6. RUSLE input factors for the conventional valley fill, post-reclamation, long term condition of the experimental watershed}

\subsubsection{GLD Post-Mining, Pre-Vegetation Condition Methods}

A C-factor value of 0.12 (Figure 4.7; Table 4.1) was assigned to the GLD post-mining, pre-vegetation condition due to the same straw or hay mulching conditions (WVDEP, 2011) used in determining the C-factor in 4.4.11 (Conventional Valley Fill Post-Mining, Pre-Revegetation Condition Methods). The C-factor for the undisturbed area surrounding the disturbed land was 
given the same value (0.003) as the undisturbed forest determined in 4.4.10 (Undisturbed, PreMining Condition Methods).

The LS-factor varied over the study area with a mean value of 9.7 and a standard deviation of 18.1. Low LS values (minimum value of 0) occurred mainly along ridgelines. High LS-factors (maximum value of 409.4) were located at stream channel locations and valley-fill face (Figure 4.7).

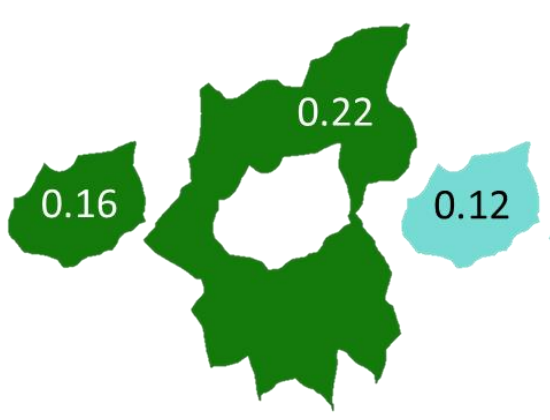

K-Factor

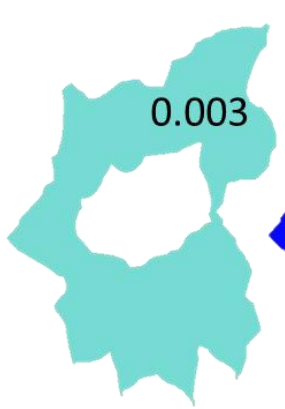

C-Factor

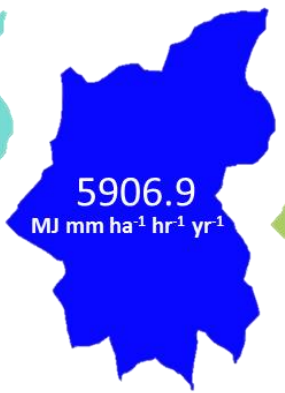

R-Factor

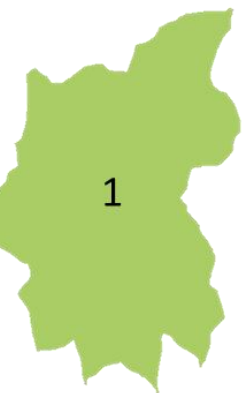

P-Factor

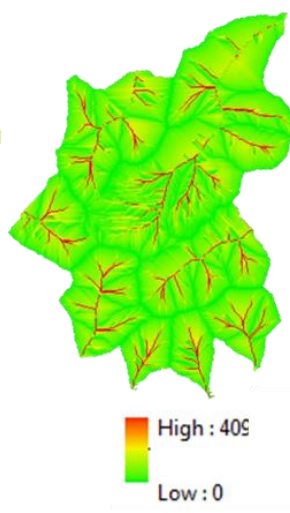

LS-Factor

Figure 4.7. RUSLE input factors for the geomorphic valley fill, pre-vegetation condition of the experimental watershed

\subsubsection{GLD Post-Reclamation, Long Term Condition Methods}

The C-factor for the GLD post-reclamation, long term condition was assigned the same value (0.012; Figure 4.8; Table 4.1) as the reclaimed forest land determined in 4.4.12 (Conventional Valley Fill Post-Reclamation, Long Term Condition Methods). The C-factor for the undisturbed area surrounding the reclaimed land was given the same value $(0.003)$ as the undisturbed forest determined in 5.4.10 (Undisturbed, Pre-Mining Condition Methods).

The LS-factor varied over the study area with a mean value of 9.7 and a standard deviation of 18.1. Low LS values (minimum value of 0) occurred mainly along ridgelines (Figure 4.8). High LS-factors (maximum value of 409.4) were located at stream channel locations and valley-fill face. 


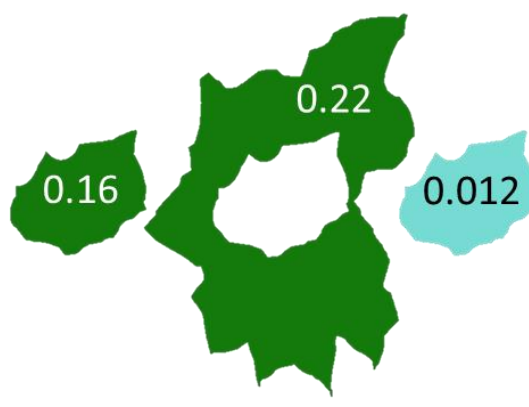

K-Factor

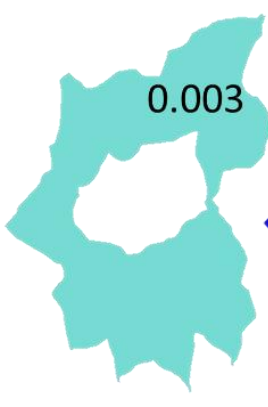

C-Factor

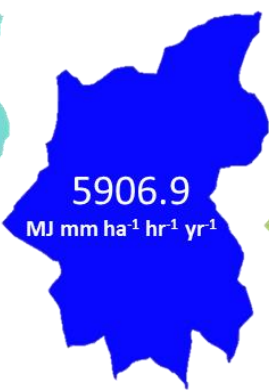

R-Factor
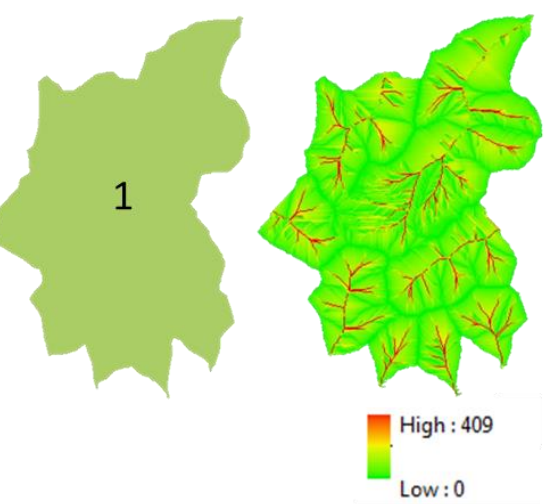

P-Factor

LS-Factor

Figure 4.8. RUSLE input factors for the geomorphic valley fill, long term condition of the experimental watershed

\subsection{Results}

The rainfall-runoff factor, soil erodibility factor, slope length and steepness factors, cover and management factor, and supporting practices factor were created as raster layers in a GIS environment and multiplied together using the RUSLE formula (Eq. 4.1) to estimate the average annual soil loss rate, spatial erosion means, and areas of increased erosion potential for the study area. Erosion analysis for the five design scenarios (i. undisturbed, pre-mining condition; ii. conventional valley fill post-mining, pre-vegetation condition; iii. conventional valley fill postreclamation, long term condition; iv. GLD post-mining, pre-vegetation condition; v. GLD postreclamation, long term condition) was completed and a comparison of the results were performed.

\subsubsection{Undisturbed, Pre-Mining Condition Results}

The undisturbed, pre-mining condition resulted in an estimated average annual soil loss rate (A) of $35.4 \mathrm{t} \mathrm{ha}^{-1} \mathrm{yr}^{-1}$. The lowest erosion rates $\left(<30 \mathrm{t} \mathrm{ha}^{-1} \mathrm{yr}^{-1}\right)$ occurred along ridgelines, following the location patterns of the low LS-factor values (Figure 4.4). The highest soil loss rates $\left(>100 \mathrm{t} \mathrm{ha}^{-1} \mathrm{yr}^{-1}\right.$; maximum of 1,654.3 $\left.\mathrm{t} \mathrm{ha}^{-1} \mathrm{yr}^{-1}\right)$ mimicked the highest LS-factor locations along the stream channels and valleys (Figure 4.9). The undisturbed area had approximately $4480 \mathrm{~m}$ of ridgelines (35-1,240 $\mathrm{m}$ range) and $6210 \mathrm{~m}$ of valleys/channels (35-860 $\mathrm{m}$ range) identified in the LS-factor and soil loss rate distributions (Figure 4.4; Figure 4.9). 


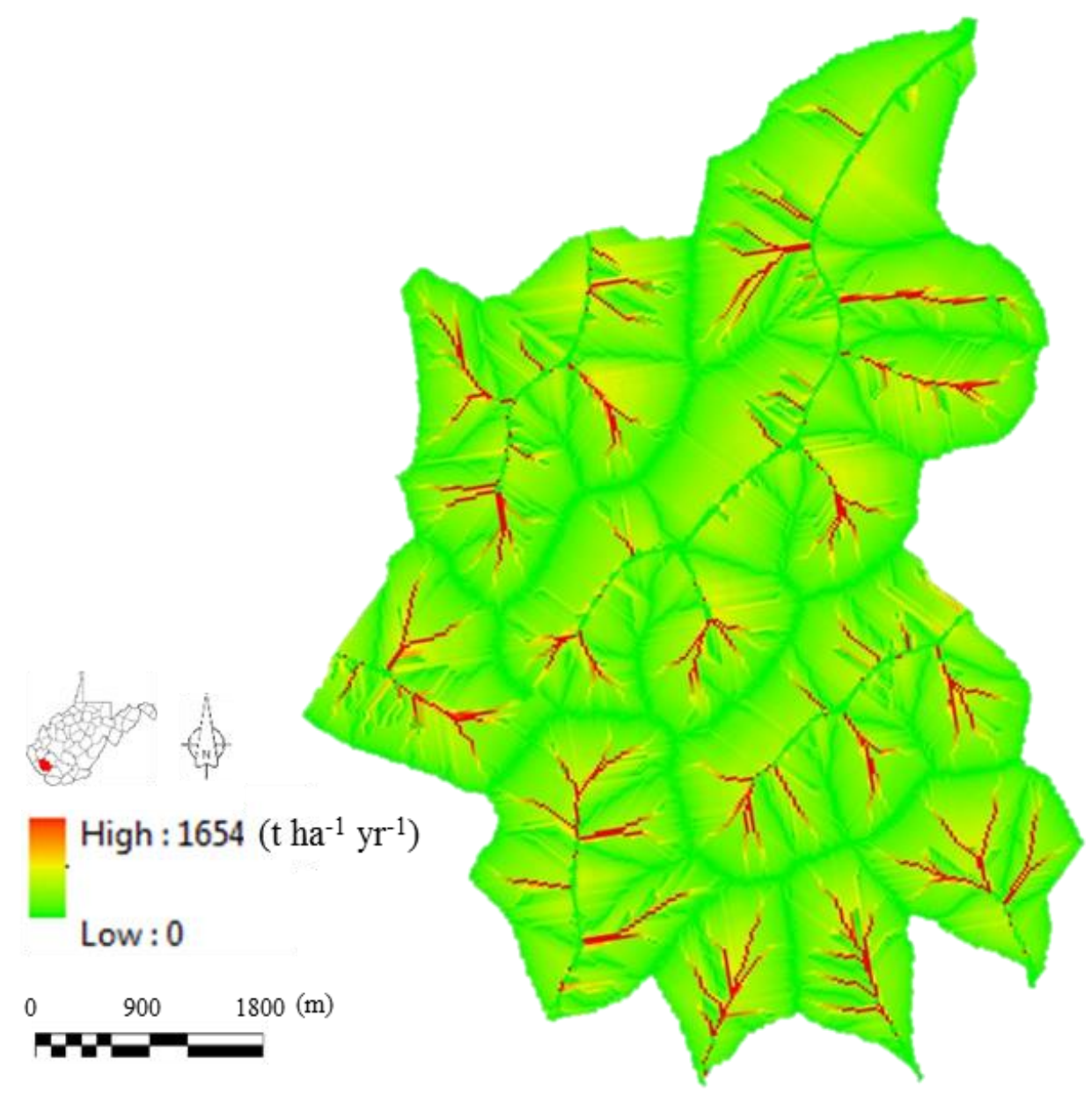

Figure 4.9. Average annual soil loss rate (A) for the undisturbed, pre-mining condition of the experimental watershed

\subsubsection{Conventional Valley Fill Post-Mining, Pre-Vegetation Condition Results}

The study site as the conventional valley fill post-mining, pre-vegetation condition had an estimated average annual soil loss rate (A) of $123.2 \mathrm{t} \mathrm{ha}^{-1} \mathrm{yr}^{-1}$ (standard deviation of $726.9 \mathrm{t} \mathrm{ha}^{-1}$ $\left.\mathrm{yr}^{-1}\right)$. Low soil loss rates $\left(<30 \mathrm{t} \mathrm{ha}^{-1} \mathrm{yr}^{-1}\right)$ occurred along the ridgelines and the valley-fill crest (Figure 4.5). The highest erosion rates ( $>100 \mathrm{t} \mathrm{ha}^{-1} \mathrm{yr}^{-1}$; maximum of 47,538.7 $\left.\mathrm{t} \mathrm{ha}^{-1} \mathrm{yr}^{-1}\right)$ were estimated to be at the entire valley-fill face, Surface Water Run-Off Analysis (SWROA) ditch locations, and highwall locations (Figure 4.10). The area surrounding the conventional fill had approximately 2,475 $\mathrm{m}$ of ridgelines (35-450 $\mathrm{m}$ range) and 4,950 $\mathrm{m}$ of valleys/channels (30-435 $\mathrm{m}$ range) identified in the LS-factor and soil loss rate distributions (Figure 4.5; Figure 4.10). The 
conventional fill area had 3,109 m of SWROA ditches along the perimeter of the fill and the area did not have any ridgelines.

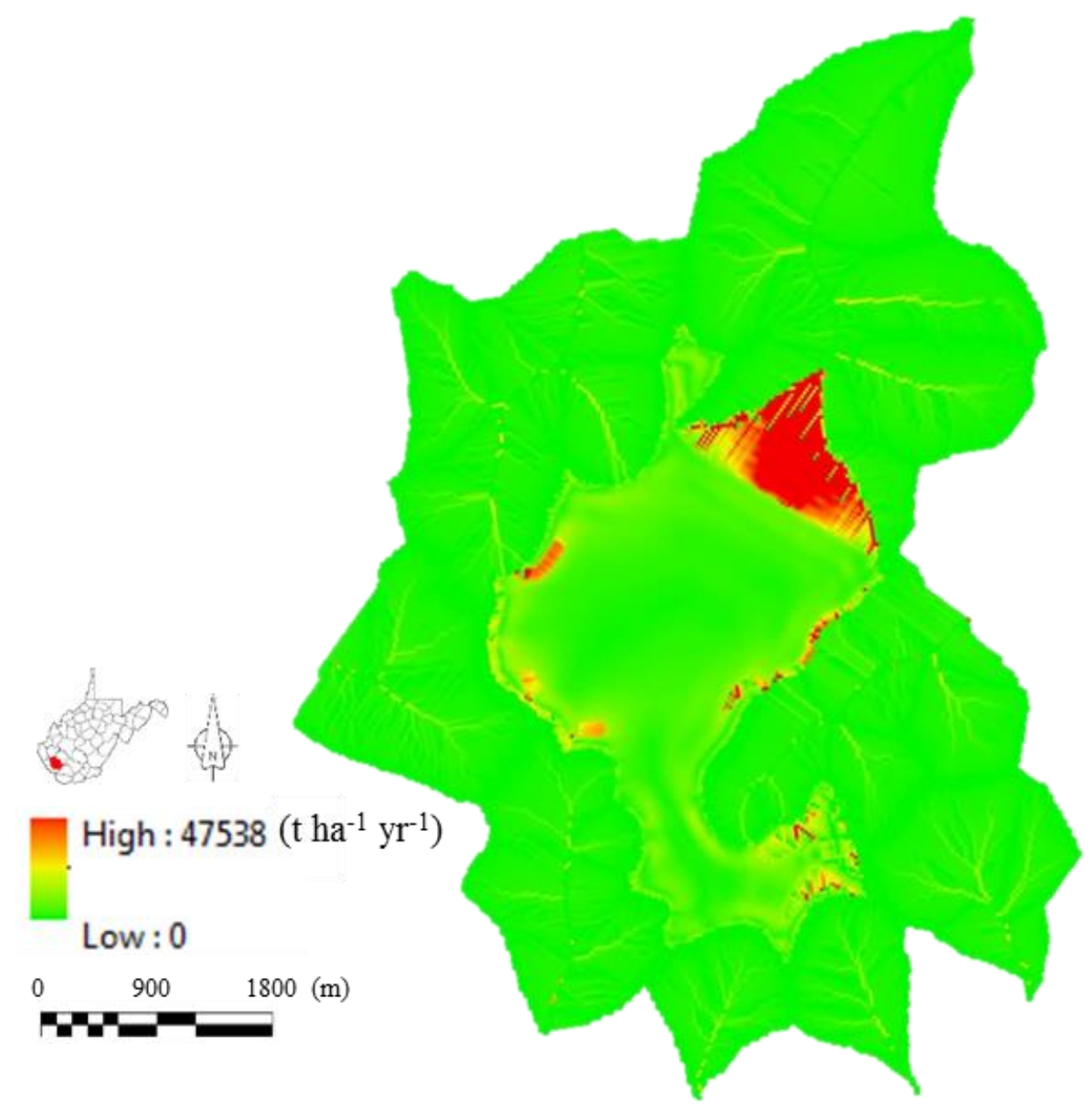

Figure 4.10. Average annual soil loss rate (A) for the conventional valley fill, pre-vegetation condition of the experimental watershed

\subsubsection{Conventional Valley Fill Post-Reclamation, Long Term Condition Results}

The conventional valley fill post-mining, long term condition resulted in a predicted average annual soil loss rate (A) of $35.6 \mathrm{t} \mathrm{ha}^{-1} \mathrm{yr}^{-1}$ with a standard deviation of $89.7 \mathrm{t} \mathrm{ha}^{-1} \mathrm{yr}^{-1}$. Low erosion rates $\left(<30 \mathrm{t} \mathrm{ha}^{-1} \mathrm{yr}^{-1}\right)$ occurred along the ridgelines and the valley-fill crest (Figure 4.6), which mimicked the low soil loss locations in the conventional valley fill, pre-vegetation condition. The highest soil loss rates (>100 $\mathrm{t} \mathrm{ha}^{-1} \mathrm{yr}^{-1}$; maximum of 4,627.7 $\left.\mathrm{t} \mathrm{ha}^{-1} \mathrm{yr}^{-1}\right)$ were 
estimated to be at the entire valley-fill face, SWROA ditches, highwalls, and stream channels (Figure 4.11).

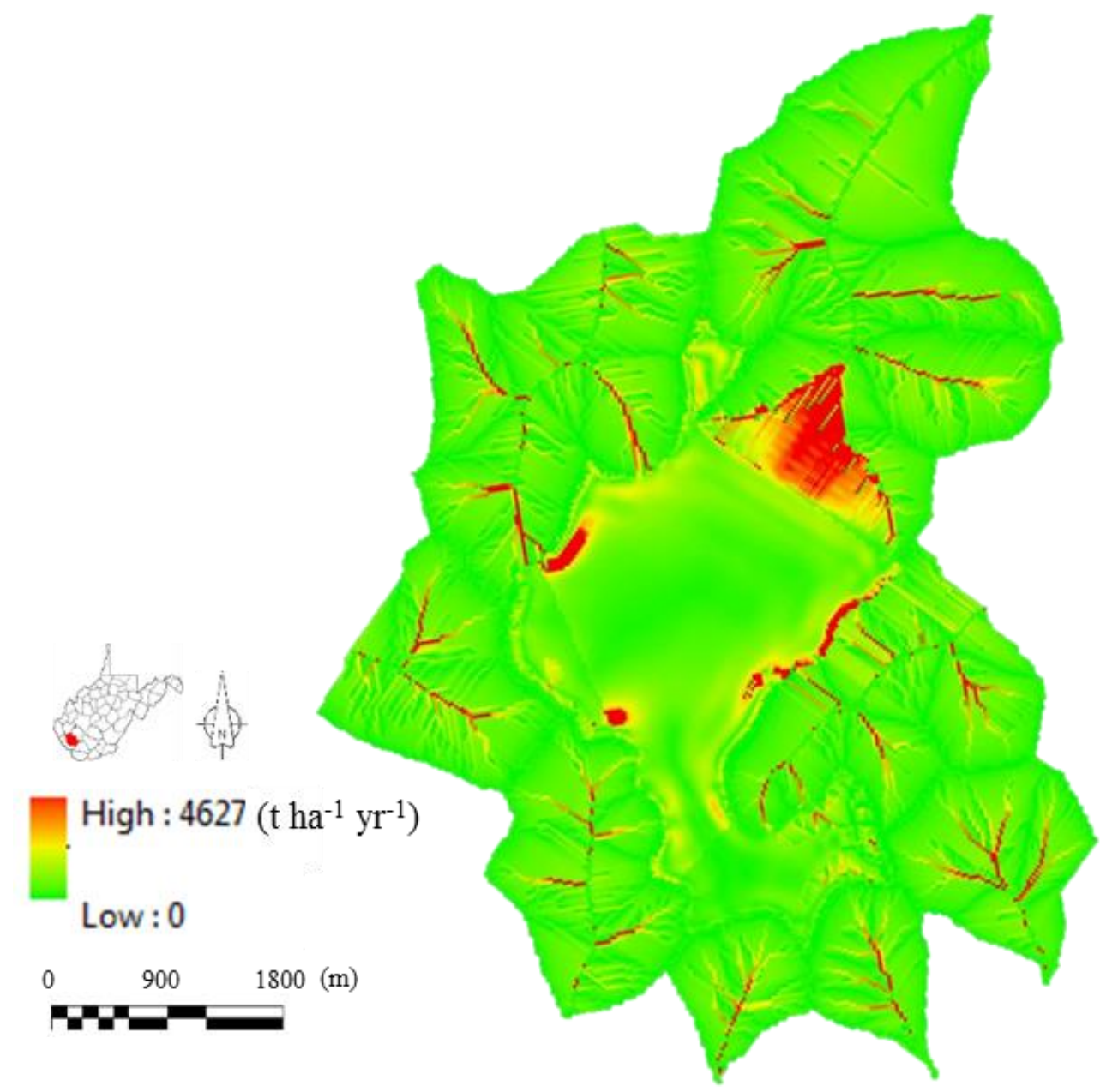

Figure 4.11. Average annual soil loss rate (A) for the conventional valley fill, postreclamation, long term condition of the watershed

\subsubsection{Undisturbed and Conventional Valley Fill Comparison}

The conventional valley fill soil erosion rate distributions (Figure 4.10; Figure 4.11) were separated into the areas used for RUSLE inputs (reclaimed forest, reclaimed pastureland, and undisturbed surrounding area; Figure 4.5; Figure 4.6) for better analysis of the spatial distributions and rates (Figure 4.12). The undisturbed, pre-mining soil erosion rate distribution (Figure 4.9) was also divided into the same areas for comparison. 
The erosion rate spatial mean of the reclaimed forest area (included fill face) for the post mining, pre-vegetation scenario (928.9 $\mathrm{t} \mathrm{ha}^{-1} \mathrm{yr}^{-1}$ ) was approximately thirty times the spatial mean of the undisturbed, pre-mining condition $\left(30.2 \mathrm{t} \mathrm{ha}^{-1} \mathrm{yr}^{-1}\right)$. The maximum erosion rate for the pre-vegetation scenario (47538.7 $\mathrm{t} \mathrm{ha}^{-1} \mathrm{yr}^{-1}$ ) was approximately forty times the spatial mean of the undisturbed, pre-mining condition (1151.3 $\left.\mathrm{t} \mathrm{ha}^{-1} \mathrm{yr}^{-1}\right)$. The post reclamation, long term condition erosion rate spatial mean (93.2 $\mathrm{t}$ ha-1 $\mathrm{yr}-1)$ was three times the spatial mean of the undisturbed, pre-mining condition. The maximum erosion rate for the long term scenario (4627.7 $\mathrm{tha}^{-1} \mathrm{yr}^{-1}$ ) was approximately four times the spatial mean of the pre-mining condition (Table 4.2).

The erosion rate spatial mean of the reclaimed pastureland area (included fill crest) for the pre-vegetation scenario $\left(138.2 \mathrm{t} \mathrm{ha}^{-1} \mathrm{yr}^{-1}\right)$ was approximately five times the spatial mean of the undisturbed, pre-mining condition $\left(25.8 \mathrm{t} \mathrm{ha}^{-1} \mathrm{yr}^{-1}\right)$. The maximum erosion rate for the prevegetation scenario (2993.0 $\mathrm{tha}^{-1} \mathrm{yr}^{-1}$ ) was approximately 3.7 times the spatial mean of the undisturbed condition $\left(810.8 \mathrm{tha}^{-1} \mathrm{yr}^{-1}\right)$. The post reclamation, long term condition erosion rate spatial mean (42.9 t ha-1 yr-1) was 1.7 times the spatial mean of the undisturbed, pre-mining condition. The maximum erosion rate for the long term scenario $\left(927.0 \mathrm{t} \mathrm{ha}^{-1} \mathrm{yr}^{-1}\right)$ was approximately 1.1 times the spatial mean of the pre-mining condition (Table 4.2).

The undisturbed area surrounding the conventional fill resulted in an erosion rate spatial mean of $27.4 \mathrm{t} \mathrm{ha}^{-1} \mathrm{yr}^{-1}$ and an erosion rate range of $0-1463 \mathrm{tha}^{-1} \mathrm{yr}^{-1}$. The erosion rate and spatial distribution did not change throughout the scenarios because the land remained undisturbed and the RUSLE inputs remained constant (Figure 4.12; Table 4.2). 


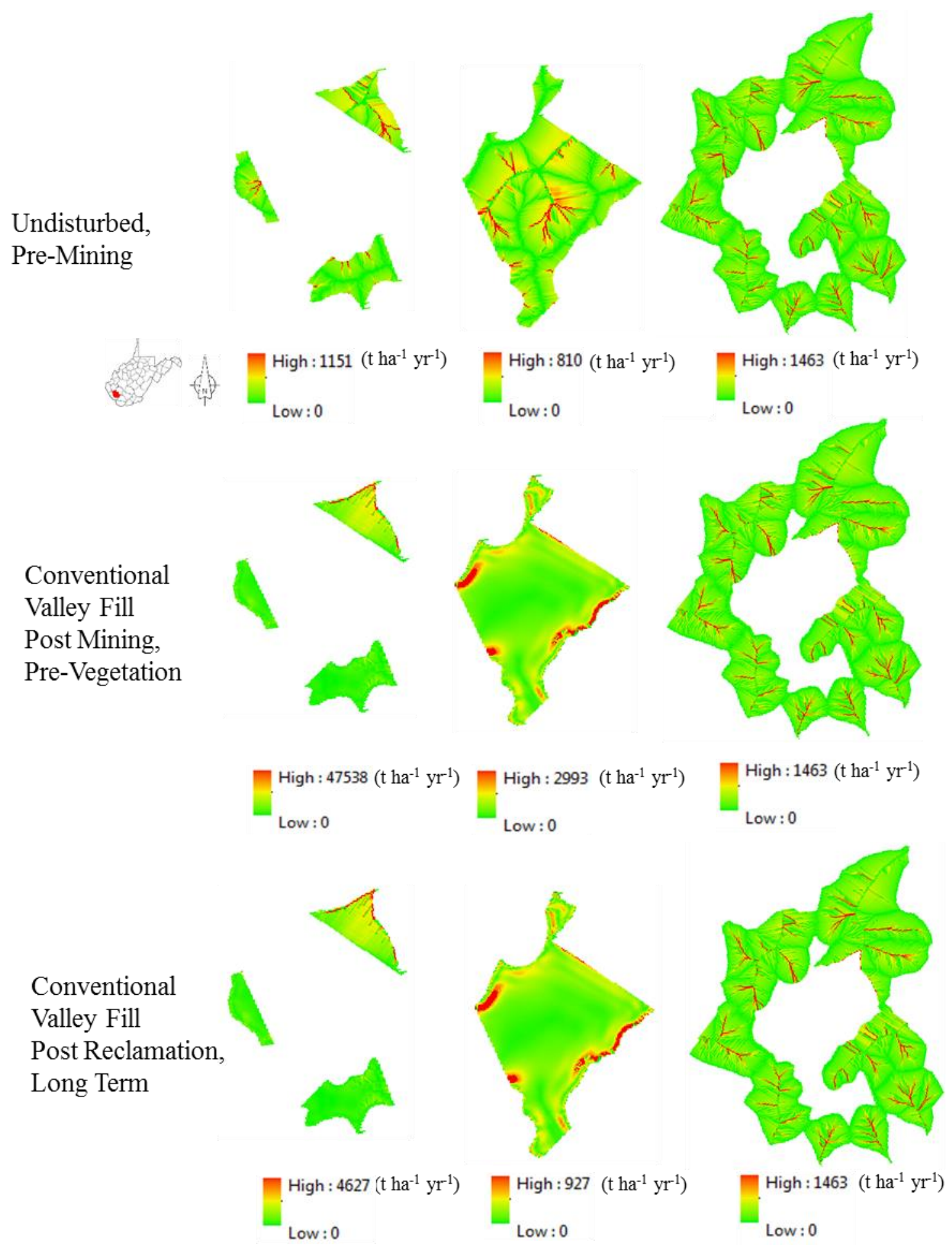

Figure 4.12. Average annual soil loss rates (A) spatial distribution for the undisturbed premining condition, conventional valley fill post mining pre-vegetation condition, and conventional valley fill post-reclamation long term condition of the watershed separated into comparison areas (reclaimed forest, reclaimed pastureland, and undisturbed surrounding area). (Not to scale) 
Table 4.2. Average annual soil loss rates (A) and ranges for the undisturbed pre-mining condition, conventional valley fill post mining pre-vegetation condition, and conventional valley fill post-reclamation long term condition of the watershed separated into comparison areas (total area, reclaimed forest, reclaimed pastureland, and undisturbed surrounding area)

\begin{tabular}{|c|c|c|c|c|}
\hline \multirow[b]{2}{*}{ Condition } & \multirow[b]{2}{*}{ Area } & \multicolumn{3}{|c|}{$A\left[t h^{-1} y^{-1}\right]$} \\
\hline & & Range & $\begin{array}{l}\text { Spatial } \\
\text { Mean }\end{array}$ & Std. Dev. \\
\hline \multirow{4}{*}{ Undisturbed, Pre-Mining } & Total Area & $0-424.3$ & 35.4 & 66.6 \\
\hline & $\begin{array}{l}\text { Reclaimed } \\
\text { Forest }\end{array}$ & $0-1151.3$ & 30.2 & 51.0 \\
\hline & $\begin{array}{l}\text { Reclaimed } \\
\text { Pastureland }\end{array}$ & $0-810.8$ & 25.8 & 36.4 \\
\hline & $\begin{array}{c}\text { Surrounding } \\
\text { Area }\end{array}$ & $0-1463.2$ & 27.4 & 59.3 \\
\hline \multirow{4}{*}{$\begin{array}{l}\text { Conventional Valley Fill } \\
\text { Post Mining, Pre-Vegetation }\end{array}$} & Total Area & $0-47538.7$ & 123.2 & 726.9 \\
\hline & $\begin{array}{l}\text { Reclaimed } \\
\text { Forest }\end{array}$ & $0-47538.7$ & 928.9 & 2324.4 \\
\hline & $\begin{array}{l}\text { Reclaimed } \\
\text { Pastureland }\end{array}$ & $0-2993.0$ & 138.2 & 200.4 \\
\hline & $\begin{array}{c}\text { Surrounding } \\
\text { Area }\end{array}$ & $0-1463.2$ & 27.4 & 59.3 \\
\hline \multirow{4}{*}{$\begin{array}{c}\text { Conventional Valley Fill } \\
\text { Post Reclamation, Long } \\
\text { Term }\end{array}$} & Total Area & $0-4627.7$ & 35.6 & 89.7 \\
\hline & $\begin{array}{l}\text { Reclaimed } \\
\text { Forest }\end{array}$ & $0-4627.7$ & 93.2 & 230.4 \\
\hline & $\begin{array}{l}\text { Reclaimed } \\
\text { Pastureland }\end{array}$ & $0-927.0$ & 42.9 & 62.3 \\
\hline & $\begin{array}{c}\text { Surrounding } \\
\text { Area }\end{array}$ & $0-1463.2$ & 27.4 & 59.3 \\
\hline
\end{tabular}

\subsubsection{GLD Post-Mining, Pre-Vegetation Condition Results}

The study site as the GLD post-mining, pre-vegetation condition had an estimated average annual soil loss rate (A) of $204.3 \mathrm{t} \mathrm{ha}^{-1} \mathrm{yr}^{-1}$ (standard deviation of $956.7 \mathrm{t} \mathrm{ha}^{-1} \mathrm{yr}^{-1}$ ). Low soil loss rates $\left(<30 \mathrm{t} \mathrm{ha}^{-1} \mathrm{yr}^{-1}\right)$ occurred along the ridgelines, which mimicked the low LS-factor value locations. High erosion rates (>100 $\mathrm{t} \mathrm{ha}^{-1} \mathrm{yr}^{-1}$; maximum of 40,030.7 $\mathrm{t} \mathrm{ha}^{-1} \mathrm{yr}^{-1}$ ) occurred along the original and created stream channels as well as the steep slopes (slope >50\%) within the geomorphic valley fill. The GLD fill area had approximately 1,420 m of ridgeline (50-865 m 
range) and 2,040 m of valleys/channels (30-440 range) identified in the LS-factor and soil loss rate distribution (Figure 4.7; Figure 4.13). The area surrounding the GLD fill had approximately $3,670 \mathrm{~m}$ of ridgelines (35-520 $\mathrm{m}$ range) and 5,300 $\mathrm{m}$ of valleys/channels (35-430 $\mathrm{m}$ range) recognized in the LS-factor and soil loss rate distributions (Figure 4.7; Figure 4.13).

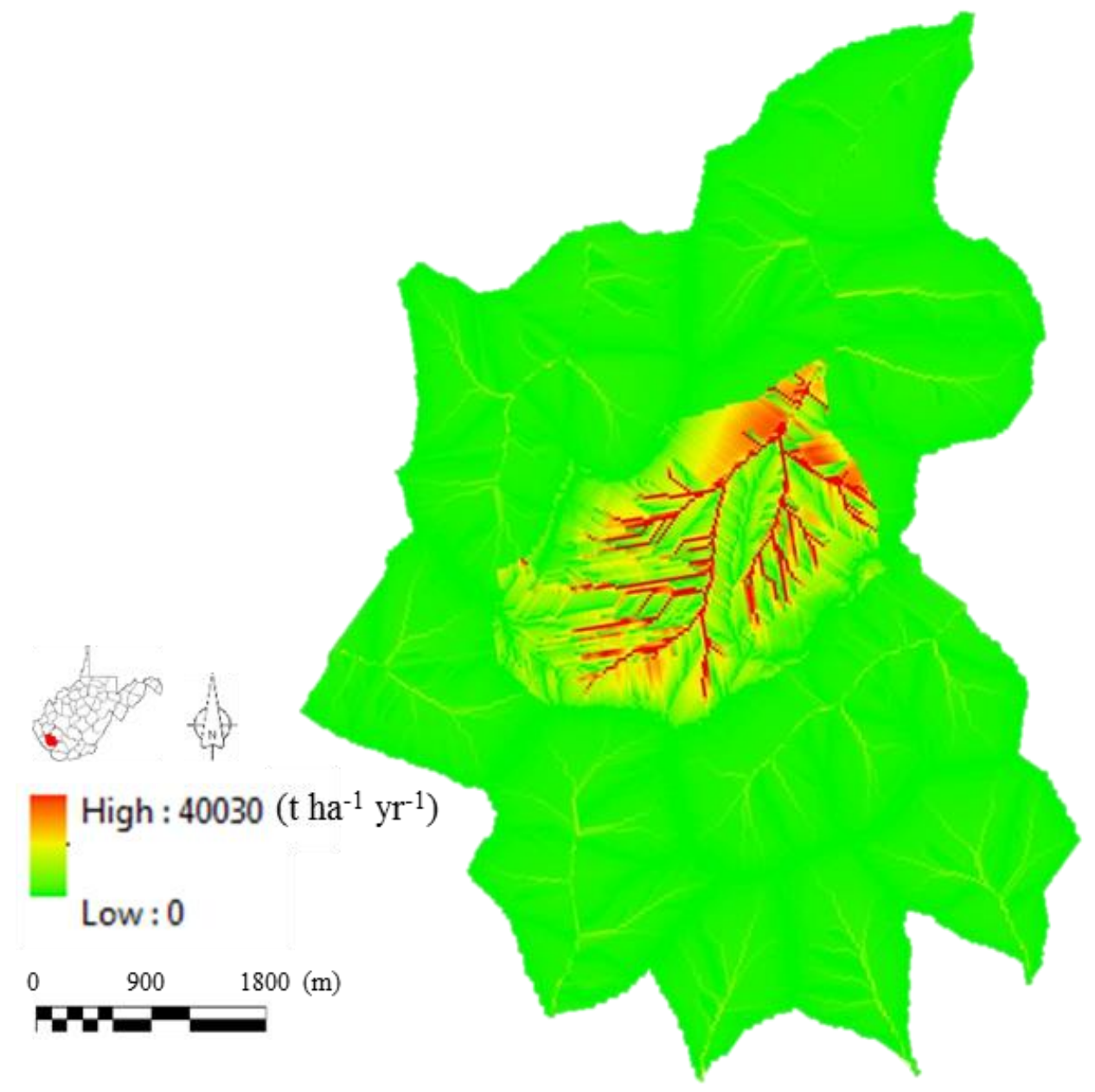

Figure 4.13. Average annual soil loss rate (A) for the geomorphic valley fill, pre-vegetation condition of the experimental watershed

\subsubsection{GLD Post-Reclamation, Long Term Condition Results}

The study site as the GLD post-reclamation, long term condition had an estimated average annual soil loss rate (A) of $41.8 \mathrm{t} \mathrm{ha}^{-1} \mathrm{yr}^{-1}\left(\right.$ standard deviation of $102.0 \mathrm{t} \mathrm{ha}^{-1} \mathrm{yr}^{-1}$ ). Low erosion rates $\left(<30 \mathrm{t} \mathrm{ha}^{-1} \mathrm{yr}^{-1}\right)$ occurred along the ridgelines, which mimicked the low LS-factor value locations. High soil loss rates $\left(>100 \mathrm{t} \mathrm{ha}^{-1} \mathrm{yr}^{-1}\right.$; maximum of 3,896.8 $\left.\mathrm{tha}^{-1} \mathrm{yr}^{-1}\right)$ occurred 
along the original and created stream channels as well as the steep slopes (slope $>50 \%$ ) within the geomorphic valley fill (Figure 4.8; Figure 4.14).

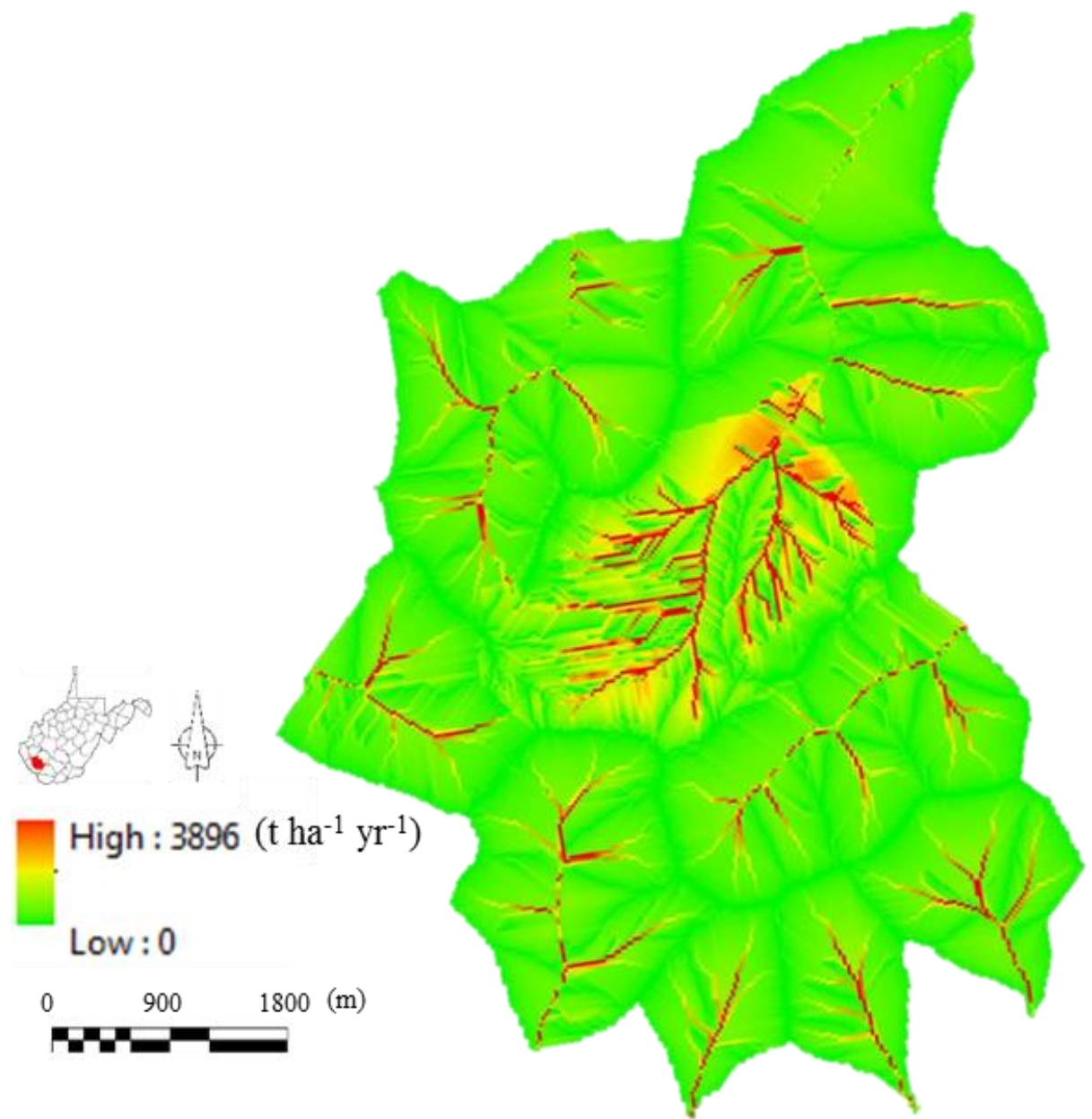

Figure 4.14. Average annual soil loss rate (A) for the geomorphic valley fill, long term condition of the experimental watershed

\subsubsection{Undisturbed and GLD Valley Fill Comparison}

The GLD valley fill soil erosion rate distributions (Figure 4.13; Figure 4.14) were separated into the areas used for RUSLE inputs (GLD and undisturbed surrounding area; Figure 4.7; Figure 4.8) for better analysis of the spatial distributions and rates (Figure 4.15). The 
undisturbed, pre-mining soil erosion rate distribution (Figure 4.9) was also divided into the same areas for comparison.

The erosion rate spatial mean of the GLD fill area for the post mining, pre-vegetation scenario (986.4 $\mathrm{t} \mathrm{ha}^{-1} \mathrm{yr}^{-1}$ ) was approximately 33 times the spatial mean of the undisturbed, premining condition $\left(30.2 \mathrm{t} \mathrm{ha}^{-1} \mathrm{yr}^{-1}\right)$. The maximum erosion rate for the pre-vegetation scenario (40030.7 $\mathrm{t} \mathrm{ha}^{-1} \mathrm{yr}^{-1}$ ) was approximately 35 times the spatial mean of the undisturbed, pre-mining condition (1151.3 $\left.\mathrm{t} \mathrm{ha}^{-1} \mathrm{yr}^{-1}\right)$. The post reclamation, long term condition erosion rate spatial mean (96.1 t ha-1 yr-1) was three times the spatial mean of the undisturbed, pre-mining condition. The maximum erosion rate for the long term scenario $\left(3896.8 \mathrm{t} \mathrm{ha}^{-1} \mathrm{yr}^{-1}\right)$ was approximately 3.4 times the spatial mean of the pre-mining condition (Table 4.3).

The undisturbed area surrounding the GLD fill resulted in an erosion rate spatial mean of $36.3 \mathrm{tha}^{-1} \mathrm{yr}^{-1}$ and an erosion rate range of 0-654.3 $\mathrm{tha}^{-1} \mathrm{yr}^{-1}$. The erosion rate and spatial distribution did not change throughout the scenarios because the land remained undisturbed and the RUSLE inputs remained constant (Figure 4.15; Table 4.3). 
Undisturbed, Pre-Mining
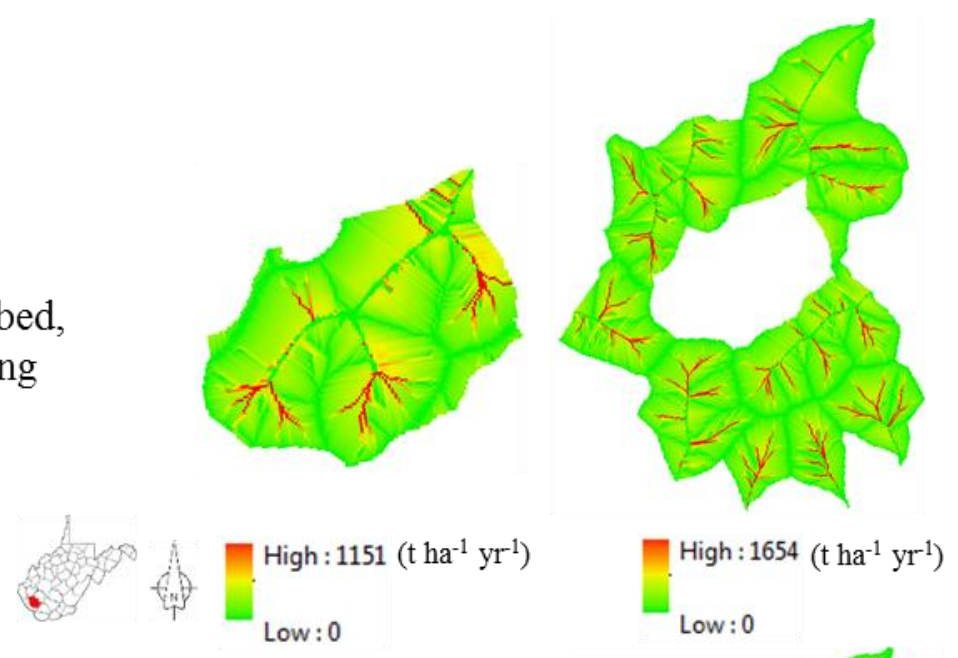

\section{GLD}

Post Mining, Pre-Vegetation
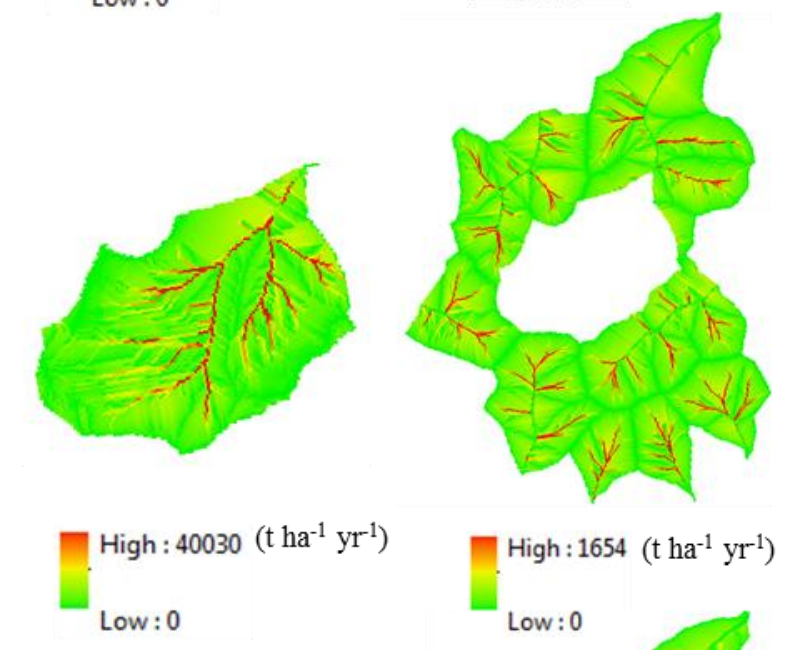

GLD

Post Reclamation, Long Term
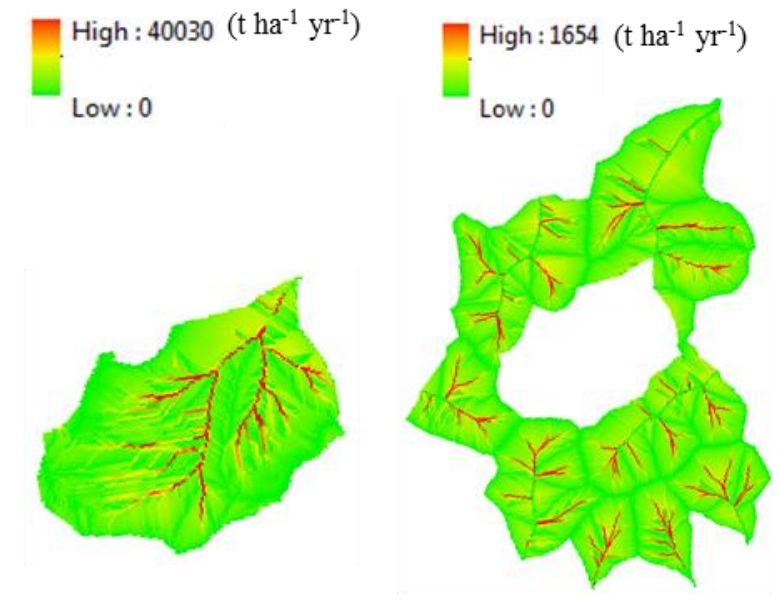

High : 3896 (t ha $\left.{ }^{-1} \mathrm{yr}^{-1}\right)$

Low : 0

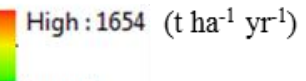

Low : 0

Figure 4.15. Average annual soil loss rates (A) spatial distribution for the undisturbed premining condition, GLD post mining pre-vegetation condition, and GLD post-reclamation long term condition of the watershed separated into comparison areas (reclaimed forest, reclaimed pastureland, and undisturbed surrounding area). (Not to scale) 
Table 4.3. Average annual soil loss rates (A) and ranges for the undisturbed pre-mining condition, GLD post mining pre-vegetation condition, and GLD post-reclamation long term condition of the watershed separated into comparison areas (total area, reclaimed forest, reclaimed pastureland, and undisturbed surrounding area)

\begin{tabular}{|c|c|c|c|c|}
\hline \multirow[b]{2}{*}{ Condition } & \multirow[b]{2}{*}{ Area } & \multicolumn{3}{|c|}{$A\left[t h^{-1} \mathrm{yr}^{-1}\right]$} \\
\hline & & Range & $\begin{array}{c}\text { Spatial } \\
\text { Mean }\end{array}$ & Std. Dev. \\
\hline \multirow{3}{*}{ Undisturbed, Pre-Mining } & Total Area & $0-424.3$ & 35.4 & 66.6 \\
\hline & GLD & $0-1151.3$ & 30.2 & 51.0 \\
\hline & $\begin{array}{l}\text { Surrounding } \\
\text { Area }\end{array}$ & $0-1654.3$ & 36.3 & 70.1 \\
\hline \multirow{3}{*}{$\begin{array}{l}\text { GLD Valley Fill } \\
\text { Post Mining, Pre-Vegetation }\end{array}$} & Total Area & $0-40030.7$ & 204.3 & 956.7 \\
\hline & GLD & $0-40030.7$ & 986.4 & 2066.9 \\
\hline & $\begin{array}{l}\text { Surrounding } \\
\text { Area }\end{array}$ & $0-1654.3$ & 36.3 & 70.1 \\
\hline \multirow{3}{*}{$\begin{array}{c}\text { GLD Valley Fill } \\
\text { Post Reclamation, Long } \\
\text { Term }\end{array}$} & Total Area & $0-3896.8$ & 41.8 & 41.8 \\
\hline & GLD & $0-3896.8$ & 96.1 & 96.1 \\
\hline & $\begin{array}{c}\text { Surrounding } \\
\text { Area }\end{array}$ & $0-1654.3$ & 36.3 & 70.1 \\
\hline
\end{tabular}

\subsection{Discussion}

Soil erosion is a natural process in which forces including water and wind transport earth materials across a given surface (Kouli et al., 2009). Surface mining and reclamation processes are understood to alter land uses and land covers; however, better understanding of how different reclamation methods effect soil erosion at mined sites is necessary for further advancement of reclamation and maintenance methods (Miller and Zegre, 2014). Soil loss rates and spatial distributions were estimated at the watershed scale of two valley-fill reclamation designs, the conventional design and an alternative geomorphic design, as well as the undisturbed land to predict potential impacts. The soil loss estimated to occur in the geomorphic landform design (GLD), conventional valley-fill design, and undisturbed watershed were compared (Table 4.4) to identify areas of increased erosion throughout the mining and reclamation practices. 
Table 4.4. Average annual soil loss rates for each modeled condition of the experimental watershed

\begin{tabular}{|c|c|c|c|}
\hline \multirow[b]{2}{*}{ Condition } & \multicolumn{3}{|c|}{$A \quad\left[t h^{-1} \mathbf{y r}^{-1}\right]$} \\
\hline & Range & $\begin{array}{l}\text { Spatial } \\
\text { Mean }\end{array}$ & $\begin{array}{l}\text { Std. } \\
\text { Dev. }\end{array}$ \\
\hline Undisturbed, Pre-Mining & $0-424.3$ & 35.4 & 66.6 \\
\hline $\begin{array}{c}\text { Conventional Valley Fill } \\
\text { Post Mining, } \\
\text { Pre-Vegetation }\end{array}$ & $0-47538.7$ & 123.2 & 726.9 \\
\hline $\begin{array}{c}\text { Conventional Valley Fill } \\
\text { Post Reclamation, } \\
\text { Long Term }\end{array}$ & $0-4627.7$ & 35.6 & 89.7 \\
\hline $\begin{array}{l}\text { GLD Post Mining, } \\
\text { Pre-Vegetation }\end{array}$ & $0-40030.7$ & 204.3 & 956.7 \\
\hline $\begin{array}{l}\text { GLD Post Reclamation, } \\
\text { Long Term }\end{array}$ & $0-3896.8$ & 41.8 & 102.0 \\
\hline
\end{tabular}

Stages in the mining and reclamation process when soil is completely void of protection from water and wind is when the soil is predicted to be at the highest risk for erosion and increased soil loss rates (Carroll et al., 2000). Therefore, barren soil is seeded and covered with straw mulch (WVDEP, 2011), but the soil remains susceptible to increased soil erosion until vegetation is established. The post-mining, pre-vegetation conditions which modeled the study site seeded and covered with straw mulch, resulted in very high maximum estimated soil loss rates for both the conventional and GLD reclamation scenarios due to no protection for the exposed soil except straw mulch (conventional: 47,538.7 $\mathrm{tha}^{-1} \mathrm{yr}^{-1}$; GLD: 40,030.7 $\mathrm{tha}^{-1} \mathrm{yr}^{-1}$; Table 4.4). As expected, long-term maximum estimated soil loss rates were decreased for the post-reclamation, long term conditions due to the established vegetation that protected the soil from surface erosion forces (conventional: 4,627.7 $\mathrm{t} \mathrm{ha}^{-1} \mathrm{yr}^{-1}$; GLD: 3,896.8 $\mathrm{tha}^{-1} \mathrm{yr}^{-1}$; Table 4.4). Post-reclamation, long term conditions resulted in maximum estimated soil loss rates that were reduced from the post-mining, pre-vegetation conditions by a factor of ten. However, the maximum estimated erosion rates for the post-reclamation, long term conditions were still a 
factor of ten higher than the undisturbed pre-mining condition soil loss rate estimate $\left(424.3 \mathrm{tha}^{-1}\right.$ $\mathrm{yr}^{-1}$; Table 4.1).

These results followed documented trends that showed soil erosion was highest when soil was completely bare and erosion decreased as time progressed and permanent vegetation was established (Hoomehr et al., 2015). Hoomehr et al. (2015) quantified the erodibility and erosivity of low-compaction, steep-sloped $\left(>20^{\circ}\right)$ reclaimed surface mine lands in the three active coal mining study sites in East Tennessee. Sediment yield averaged $116 \mathrm{t} \mathrm{ha}^{-1}$ for the three month study period (June-August 2009) during which rill development occurred and total sediment yield averaged $391 \mathrm{t} \mathrm{ha}^{-1}$ for the sites over the entire study period (June 2009-July 2010).

The substantial difference among the estimated soil loss rates, A, of the pre-vegetation conditions and long term conditions resulted from the RUSLE C-factor value inputs. The Cfactor values for the GLD scenarios were 0.12 for the pre-vegetation condition and 0.012 for the long term condition. The GLD pre-vegetation scenario resulted in an erosion rate spatial mean 4.9 times higher than the long term condition and a maximum soil loss rate 10.3 times higher than the long term condition. C-factor values for the conventional reclamation scenarios were 0.12 for the pre-vegetation condition and 0.038 and 0.012 for the long term condition. The conventional fill pre-vegetation scenario resulted in an erosion rate spatial mean 3.5 times higher than the long term condition and a maximum soil loss rate 10.3 times higher than the long term condition (Table 4.4).

Spatial means of the predicted erosion rates resulted in substantial difference among the undisturbed condition and the post-mining, pre-vegetation conditions for both the conventional and GLD reclamation scenarios. The conventional fill pre-vegetation scenario resulted in an erosion rate spatial mean 3.5 times higher than the undisturbed condition. The GLD prevegetation scenario resulted in an erosion rate spatial mean 5.8 times higher than the undisturbed condition. However, there was no considerable difference among the spatial means of the predicted erosion rates of the undisturbed, pre-mining condition $\left(35.4 \mathrm{t} \mathrm{ha}^{-1} \mathrm{yr}^{-1}\right)$ and the conventional (35.6 t ha- $\left.\mathrm{yr}^{-1}\right)$ and GLD (41.8 $\mathrm{t} \mathrm{ha}^{-1} \mathrm{yr}^{-1}$ ) post-reclamation, long term conditions (Table 4.4).

Predicted erosion spatial means of the post-mining, pre-vegetation conditions (conventional: 123.2 $\mathrm{t} \mathrm{ha}^{-1} \mathrm{yr}^{-1}$; GLD: $204.3 \mathrm{t} \mathrm{ha}^{-1} \mathrm{yr}^{-1}$; Table 4.4) were similar to previously 
documented soil loss rates of reclaimed spoil $\left(91.5 \mathrm{t} \mathrm{ha}^{-1} \mathrm{yr}^{-1}\right.$ to $391 \mathrm{t} \mathrm{ha}^{-1} \mathrm{yr}^{-1}$; Curtis and Superfesky, 1977; McIntosh and Barnhisel, 1993; Carroll et al., 2000; Hoomehr et al., 2015). Curtis and Superfesky (1977) reported the sediment yield from a 36\% slope reclamation spoil in East Tennessee during a twenty month study period as $526 \mathrm{t} \mathrm{ha}^{-1}$. McIntosh and Barnhisel (1993) documented a sediment yield of $91.5 \mathrm{t} \mathrm{ha}^{-1}$ on a 9\% slope in Eastern Kentucky. Sediment yields studied by Carroll et al. (2000), ranged from 314-1120 $\mathrm{t} \mathrm{ha}^{-1}$ over a four year monitoring period for three slope gradients $(10,20,30 \%)$ on three central Queensland coal mines. Each of the studies reported rill development on site immediately following reclamation. Both the conventional (123.2 $\left.\mathrm{t} \mathrm{ha}^{-1} \mathrm{yr}^{-1}\right)$ and GLD (204.3 $\mathrm{t} \mathrm{ha}^{-1} \mathrm{yr}^{-1}$ ) pre-vegetation spatial means were lower than the $315.6 \mathrm{t} \mathrm{ha}^{-1} \mathrm{yr}^{-1}$ erosion rate reported by Curtis and Superfesky (1977), higher than the $91.5 \mathrm{t} \mathrm{ha}^{-1}$ soil loss reported by McIntosh and Barnhisel (1993), and within the sediment yield range of $78.5 \mathrm{tha}^{-1} \mathrm{yr}^{-1}$ to $280 \mathrm{tha}^{-1} \mathrm{yr}^{-1}$ reported by Carroll et al. (2000).

Spatial distribution patterns of the soil loss of the GLD conditions had similar patterns to the original topography due to the similar pattern of stream channels, topography, and slope gradients (Figure 4.15). Both the undisturbed topography and the GLD topography had ridges (undisturbed: 4,480 m; GLD: 5,090 m), valleys (undisturbed: 6,210 m; GLD: 7,340 m), stream channels (undisturbed: 3,130 m; GLD: 5,466 m; dendritic drainage pattern), and slopes (undisturbed: slope 0.5-205\%; GLD: slope 0-264\%) in similar locations. Low soil loss rates for both the undisturbed condition and GLD conditions $\left(<30 \mathrm{t} \mathrm{ha}^{-1} \mathrm{yr}^{-1}\right)$ occurred along the ridgelines. High erosion rates (>100 $\mathrm{t} \mathrm{ha}^{-1} \mathrm{yr}^{-1}$ ) occurred along the valleys, stream channels, and steep slopes (slope >50\%). However, RUSLE could have overestimated the erosion rates in channels due to not modeling concentrated flow, only sheet and rill flow.

The soil loss patterns of the conventional reclamation designs identified areas with increased erosion rates (>100 $\left.\mathrm{tha}^{-1} \mathrm{yr}^{-1}\right)$, which included the valley-fill face, SWROA ditches, and highwalls (Figure 4.12). The valley-fill face and highwalls had increased soil loss rates, potentially due to their steep (2:1 slopes), planar surfaces (11 benches; 6.1-6.4 m wide every 15.2 vertical $\mathrm{m}$ in elevation). SWROA ditch locations were poetentially more susceptible to erosion because of the geometric construction, with sides perpendicular to the fill surface, unlike natural channels. Also, RUSLE could have overestimated the soil loss rates in the SWROA ditches due to the model not incorporating any riprap or additional structures implemented in the SWROA 
ditch designs. Future maintenance could be targeted to high erosion areas and design methods could be improved by decreasing the high erosion areas in future designs.

Increases in soil loss and sedimentation and the resulting economic and environmental impacts have made erosion one of the most serious watershed problems to date (Demirci and Karaburun, 2012). Demirci and Karaburun (2012) used RUSLE in a GIS framework to predict soil erosion risks in a watershed in Istanbul, Turkey disturbed by deforestation, overgrazing and incorrect agricultural activities. Reduction of soil erosion through the implementation of improved reclamation methods and limiting high erosion areas would reduce the excess sediment load that typically occurs downstream of mining and reclamation sites. Excess sedimentation can clog stream channels, contribute to contamination, and increase maintenance costs. Increased sedimentation causes loss of aquatic biodiversity in rivers and reservoirs by pollution, eutrophication, and turbidity (Wang et al., 2009, Dimirci and Karaburun, 2012). Therefore, minimization of excess sediment load caused by erosion as a result of mining is important for future improvement of reclamation methods.

This research provided estimated soil loss rates and spatial distribution patterns caused by multiple surface mining and reclamation techniques in Central Appalachia minefields. The soil loss prediction technique used in this study has the potential to be applied to many reclamation simulations with differing soil characteristics and land uses. These soil erosion prediction models illustrate the importance of reclamation design improvement needed for the surface mining industry in Central Appalachia. 


\section{Hydrologic Response of Valley-Fill Designs at the Landscape Scale}

\subsection{Introduction}

The leading cause of landscape disturbance and land use change in Central Appalachia is due to surface mining and reclamation (Ferrari et al., 2009; Miller and Zegre, 2014). Surface coal mining relies on fill construction to facilitate the extracted spoil material and mineral source. Valley-fill construction using traditional techniques involves end-dumping overburden material into nearby valleys, creating engineered fill structures with planar slopes and benched faces. Mining and valley-fill reclamation methods including vegetation removal, prolonged soil exposure, and predominant re-vegetation of grass often lead to altered hydrologic responses within the watershed for which they are located as documented by Bonta et al. (1997), Ferrari et al. (2009), and Miller and Zegre (2014).

Hydrologic response is often defined as the process of rainfall transitioning to runoff and includes watershed routing, loss, and storage processes (Kult et al., 2015). Proper understanding of hydrologic responses have important implications for the mitigation of possible flood damage to human life, property, and wildlife (Eshleman, 2004). Surface mining and reclamation practices can change hydrologic response within the watershed by burying headwater streams and altering flow paths, peak runoff, total runoff, infiltration, and evapotranspiration (Zhang et al., 2009; Miller and Zegre, 2014).

Geomorphic landform design has been identified as a potential reclamation practice for surface mined lands and valley fills in Central Appalachia (Russell and Quaranta, 2013; Sears et al., 2013; Sears et al., 2014) due to its successful implementation in areas outside of Central Appalachia, particularly in semi-arid regions of the southwestern U.S. (Measles and Bugosh, 2007; Martin-Moreno et al., 2008; Martin-Duque et al., 2009). Research studies for geomorphic landform design (GLD) in Central Appalachia have focused on establishing design protocol (Sears et al., 2012; Sears et al., 2013), testing slope stability (Russell et al., 2014), evaluating flooding and stormwater movement of a single reclaimed valley fill (Snyder, 2013; O’Leary, 2014), and identifying implementation challenges (Depriest et al., 2015). Limited research has been completed to quantify the effects of surface mining and valley-fill construction on hydrologic response at the landscape scale $\left(>100 \mathrm{~km}^{2}\right)$ (Ferrari et al., 2009; Miller and Zegre, 2014). 


\subsection{Research Question and Objectives}

Improved understanding of the hydrologic processes altered by mining and reclamation at the landscape scale would be beneficial for the mitigation of possible flood damage and for reclamation practice improvement in Central Appalachia. Therefore, a single research question was posed for this chapter:

- How is the hydrologic response altered at the landscape scale by different valleyfill reclamation methods?

Two objectives were identified to answer the research question:

- Compare changes in streamflows and volumes among the traditional reclamation and GLD reclamation for the current condition (2011-2020)

- Compare changes in streamflows and volumes among the undisturbed land, traditional reclamation, and the GLD reclamation for the future condition (20412050)

\subsection{Background: Hydrologic Simulation Program-FORTRAN}

Hydrologic Simulation Program-FORTRAN (HSPF) is a comprehensive, conceptual, dynamic watershed scale model which simulates non-point source hydrology and water quality, combines it with point source contributions, and performs flow and water quality routing in the watershed reaches (Singh et al., 2004). The three main modules in HSPF simulate the hydrologic processes and water quality on pervious and impervious land surfaces, free-flow reaches, and mixed reservoirs for extended periods of time. HSPF requires data on the physical measurements and related parameters that describe the land area, channels, and reservoirs. Additional data needed for the watershed simulation includes meteorological records of precipitation, estimates of potential evapotranspiration, and data for the water quality simulation such as surrounding land activity (agriculture, urbanization, etc.) and weather (air temperature, wind, humidity, solar radiation, etc.) (Atkins et al., 2005).

HSPF has one of the most complex mechanisms for simulation of subsurface water quality processes in both saturated and unsaturated zones. The water quality procedures for sediment erosion, pollutant interaction, and groundwater quality, as well as the ability to comprise many types of land uses and pollutant sources provide an advantage when using HSPF with large, complex watersheds (Donigian and Huber, 1991). HSPF is also the core watershed 
simulation module for BASINS software (Ferrari et al., 2009). BASINS is generally used to compile input data and create the User Control Input (UCI) file to perform the HSPF simulations. HSPF has been used to assess the effects of land-use change (Brun and Band, 2000; Singh et al, 2004; Ferrari et al., 2009), mining (Ferrari et al., 2009; Zhang et al., 2009), and reclamation practices (Ferrari et al., 2009).

Ferrari et al. (2009) estimated surface mining and reclamation effects on flood response in a disturbed $187 \mathrm{~km}^{2}$ Maryland watershed using HSPF. Results from the study indicated that surface mining and reclamation resulted in landscape conditions more similar to urbanized areas than areas of deforestation. Zhang et al. (2009) reviewed the abilities of HSPF and GIS to evaluate land use/land cover changes from phosphate mining and reclamation activities in China and the U.S. The review verified the capability of HSPF with GIS to simulate land cover changes through hydrologic modeling. Brun and Band (2000) used HSPF and GIS to investigate relationships between runoff ratio and baseflow as a function of impervious cover and soil saturation for a $91 \mathrm{~km}^{2}$ watershed in Maryland undergoing urbanization. Study results showed baseflow decreased by $20 \%$ and no substantial changes in runoff ratio occurred between preurbanization and urbanization (approximately 18\% impervious cover due to urban development). Singh et al. (2004) used HSPF and Soil and Water Assessment Tool (SWAT) to model the hydrology of a $5570 \mathrm{~km}^{2}$ Illinois watershed for urban and agriculture restoration effort assessment. Results from the study indicated that both HSPF and SWAT generally predicted daily, average monthly, and annual stream flows close to the respective observed stream flows for the experimental watershed.

\subsection{Methods}

HSPF was used in conjunction with BASINS to predict streamflow and volume for an experimental watershed in Central Appalachia. Two time periods, 2011-2020 and 2041-2050, and three valley-fill reclamation conditions were modeled to predict hydrologic response changes in streamflow and volume. The three reclamation conditions were modeled by altering land use inputs and included: i) no land disturbance occurred; ii) all valley fills reclaimed using traditional techniques; and iii) all valley fills reclaimed using GLD methods. 


\subsubsection{Study Area and Land Use}

The experimental watershed was located in Boone County, West Virginia, USA and was in the Central Appalachian ecoregion (USEPA, 2013). The watershed was serviced by USGS 03198350 Clear Fork at Whitesville, WV (Lat 3757'58', Long 81³1'28’) and had a drainage area of $166.8 \mathrm{~km}^{2}$. The elevation of the site ranged from $52 \mathrm{~m}$ to $297 \mathrm{~m}$. Average annual precipitation was $1.23 \mathrm{~m}$ and the average annual temperature was $11^{\circ} \mathrm{C}$ (Idcide, 2015). The undisturbed topography consisted of complex slope profiles (concave-convex) with ridges, valleys, and type A and C stream channels as defined by Rosgen (1994). The hydrology of the site included a main perennial channel with contributing tributaries, likely ephemeral to intermittent, in a dendritic drainage pattern. The experimental watershed was delineated into nine subwatersheds using BASINS (Fig. 5.1). 


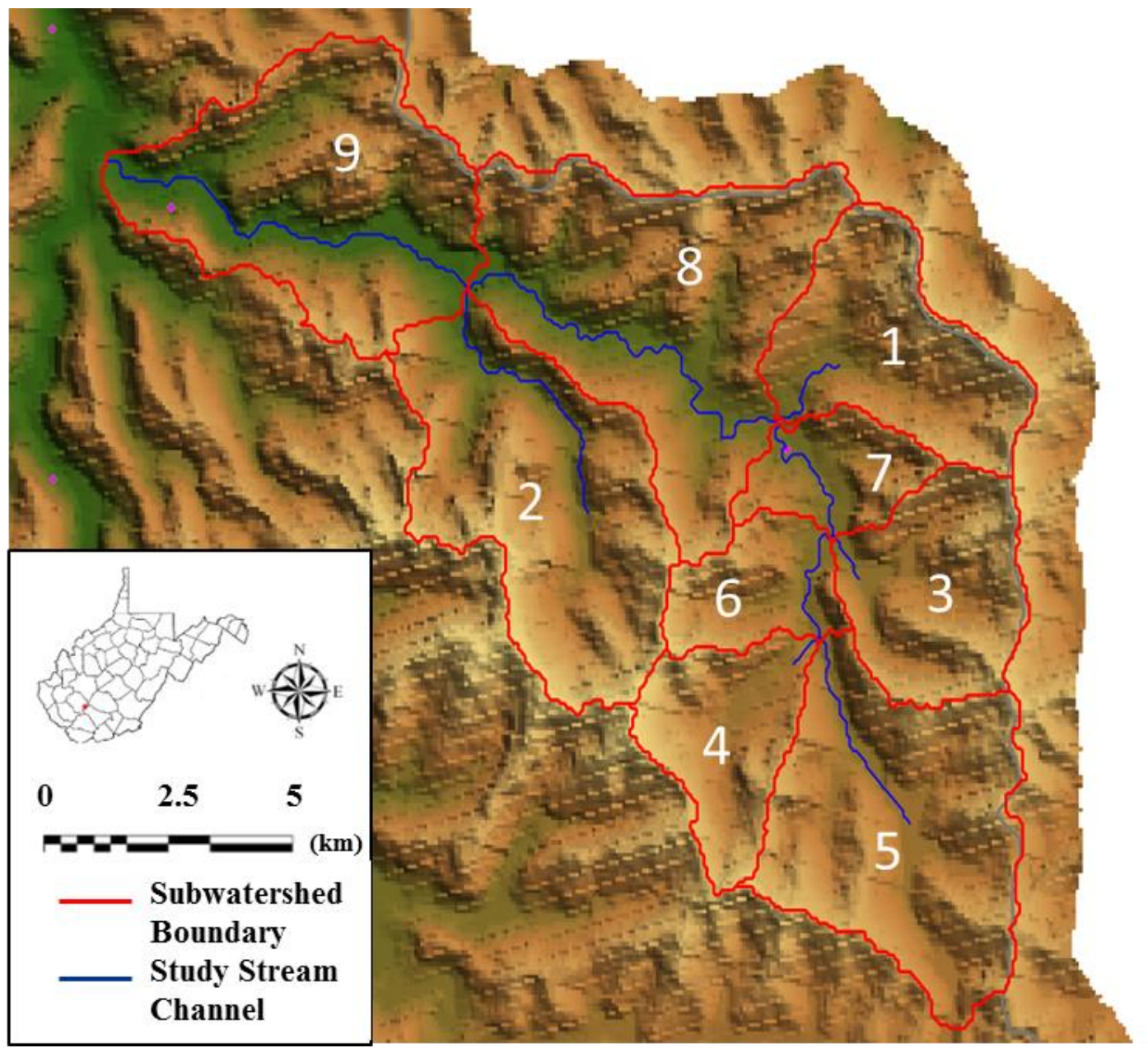

Figure 5.1. Clear Fork experimental watershed, delineated with labeled subwatersheds

The undisturbed vegetation of the study watershed consisted of predominately deciduous forest with the dominant land use of forestland (Fig. 5.2); however, 31\% of the site area in 2011 was a combination of barren and grassland. The dominant land use alteration cause was assumed to be surface mining and valley-fill reclamation practices due to the mining activity in the surrounding areas. Within the experimental watershed in $2011,21 \%$ of the disturbed area (barren and grassland) or $6.6 \%$ of the total watershed area was classified as valley fills.

The 2001 land use areas for the study watershed were consolidated into six primary land use/land cover conditions (forest, grass/reclaimed land, agriculture pasture, barren/mining land, wetlands/water, and developed/urban land) for model inputs (Figure 5.2). All land use conditions were estimated to be permeable. The urban or built-up land condition was estimated 
to be $50 \%$ pervious and $50 \%$ impervious due to roadways, buildings, parking lots, etc. (Appendix A).

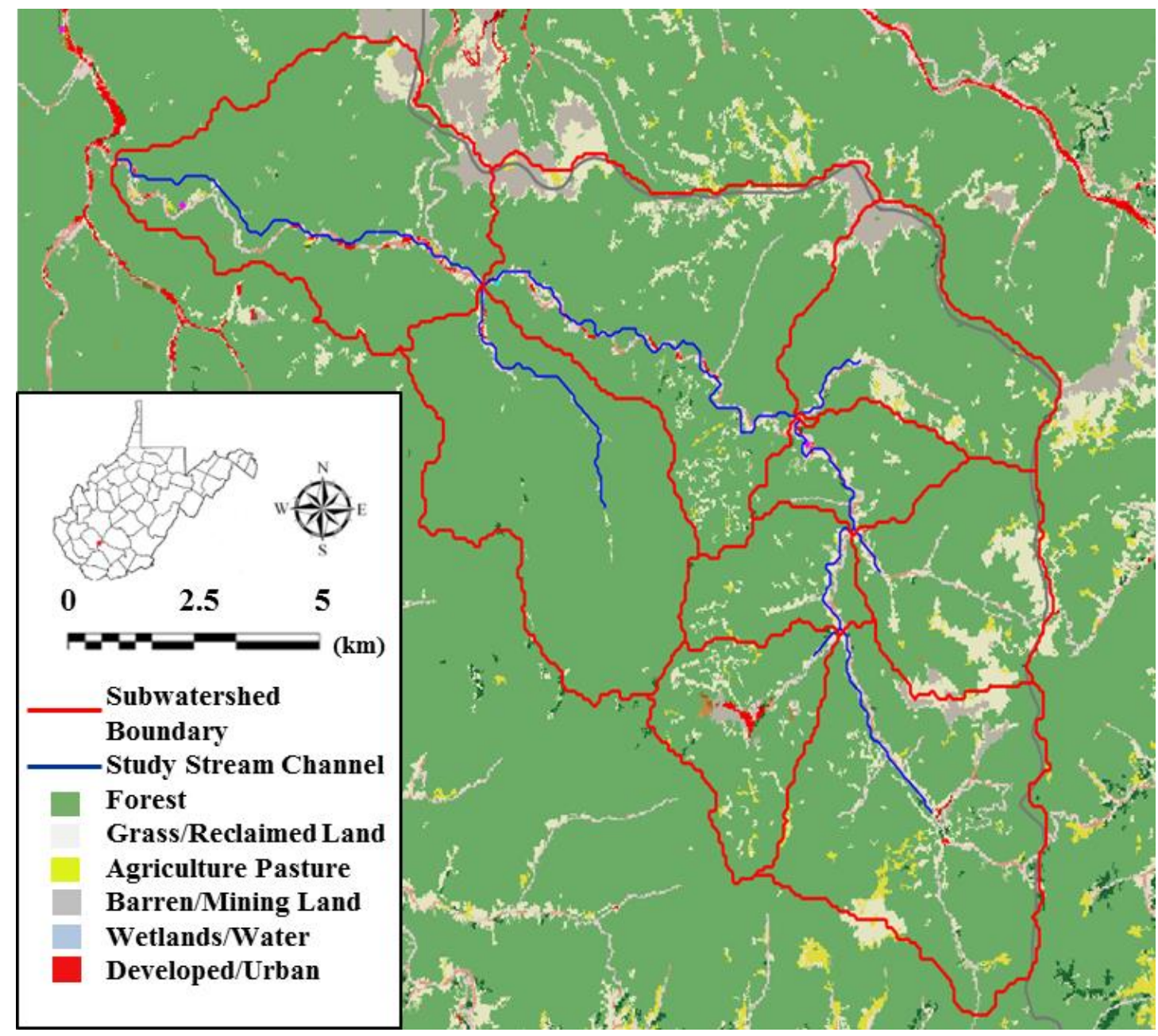

Figure 5.2. Clear Fork experimental watershed, delineated with 2001 land use

\subsubsection{Watershed Modeling Using BASINS and HSPF}

HSPF was used with BASINS to predict the hydrologic responses of the experimental watershed for multiple valley-fill reclamation conditions. Site specific data including elevation, precipitation, and streamflow were downloaded within BASINS to create the user control input (UCI) file for the HSPF simulations. The data compiled for the HSPF modeling of the study watershed are identified in Table 5.1. 
Table 5.1. HSPF model input data and sources

\begin{tabular}{ll}
\hline Description & Source \\
\hline 3-m Digital Elevation Model (DEM) & BASINS \\
Mining Permit Boundaries & WV DEP Technical Applications and GIS Unit \\
Meteorological Stations and Data & BASINS \\
Land Use & BASINS; Multi-Resolution Land Characteristics \\
Streamflow & Consortium (MRLC) \\
\hline
\end{tabular}

\subsubsection{Model Calibration}

The HSPF model calibration process was a test of the model with known input and output information that were used to adjust or estimate factors for which data were not available (Duda et al., 2012). Meteorological data for the Dry Creek weather station (approximately 13 miles from study watershed) was available for 2000-2009 and were vital for hydrologic modeling. Nine years of precipitation data (Figure 5.3) were used to incorporate a wide range of meteorological conditions including periods of below average and above average precipitation (Figure 5.4). Average precipitation for the Dry Creek watershed in 2002 was $31 \%$ less than the historical average precipitation; however, in 2004, the average precipitation was 37\% higher than the historical average precipitation. Precipitation data for years 2001 and 2009 were omitted from analysis due to not having a full year of precipitation data available. 


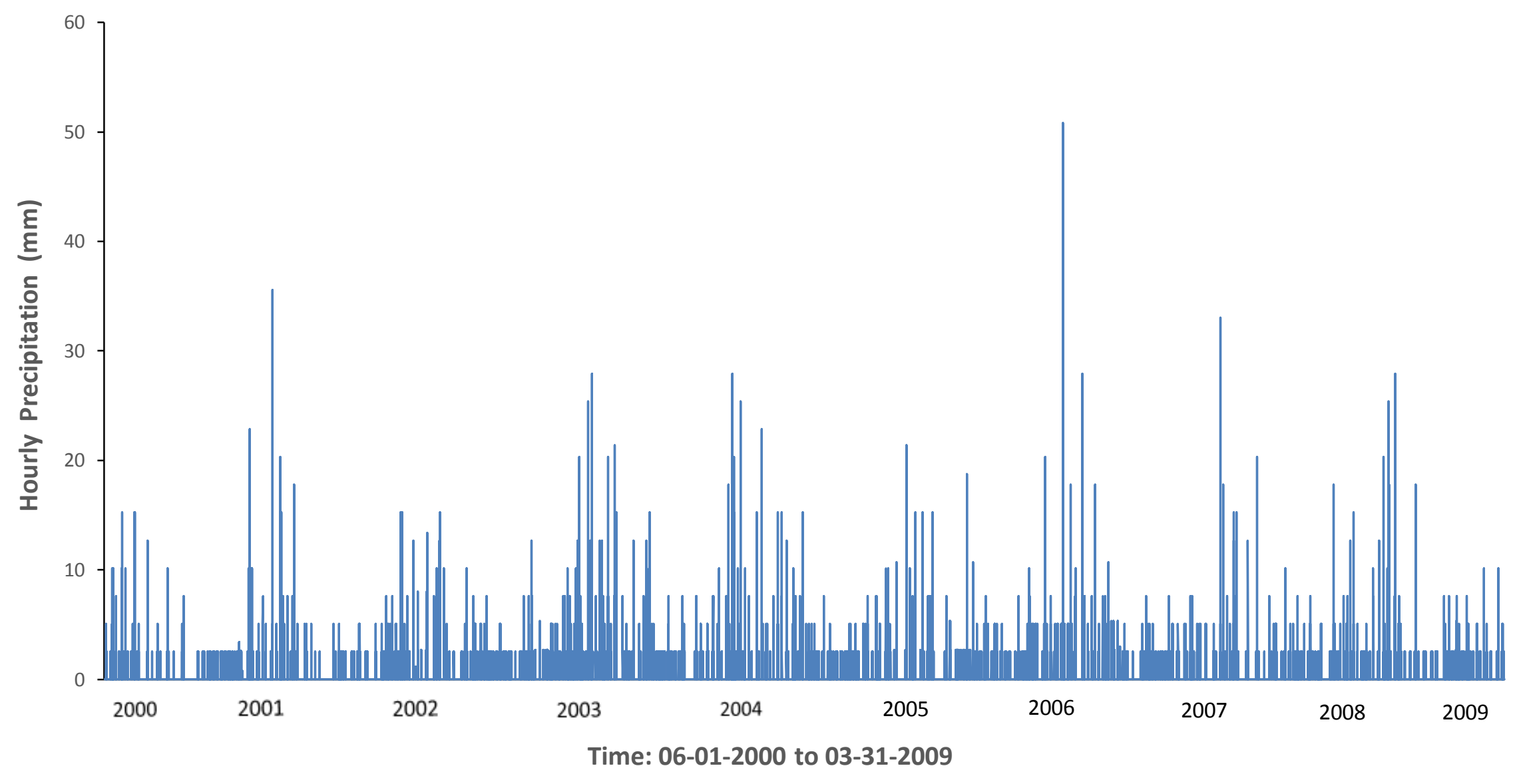

Figure 5.3 Dry Creek weather station average hourly precipitation from 06-01-2000 to 03-31-2009 


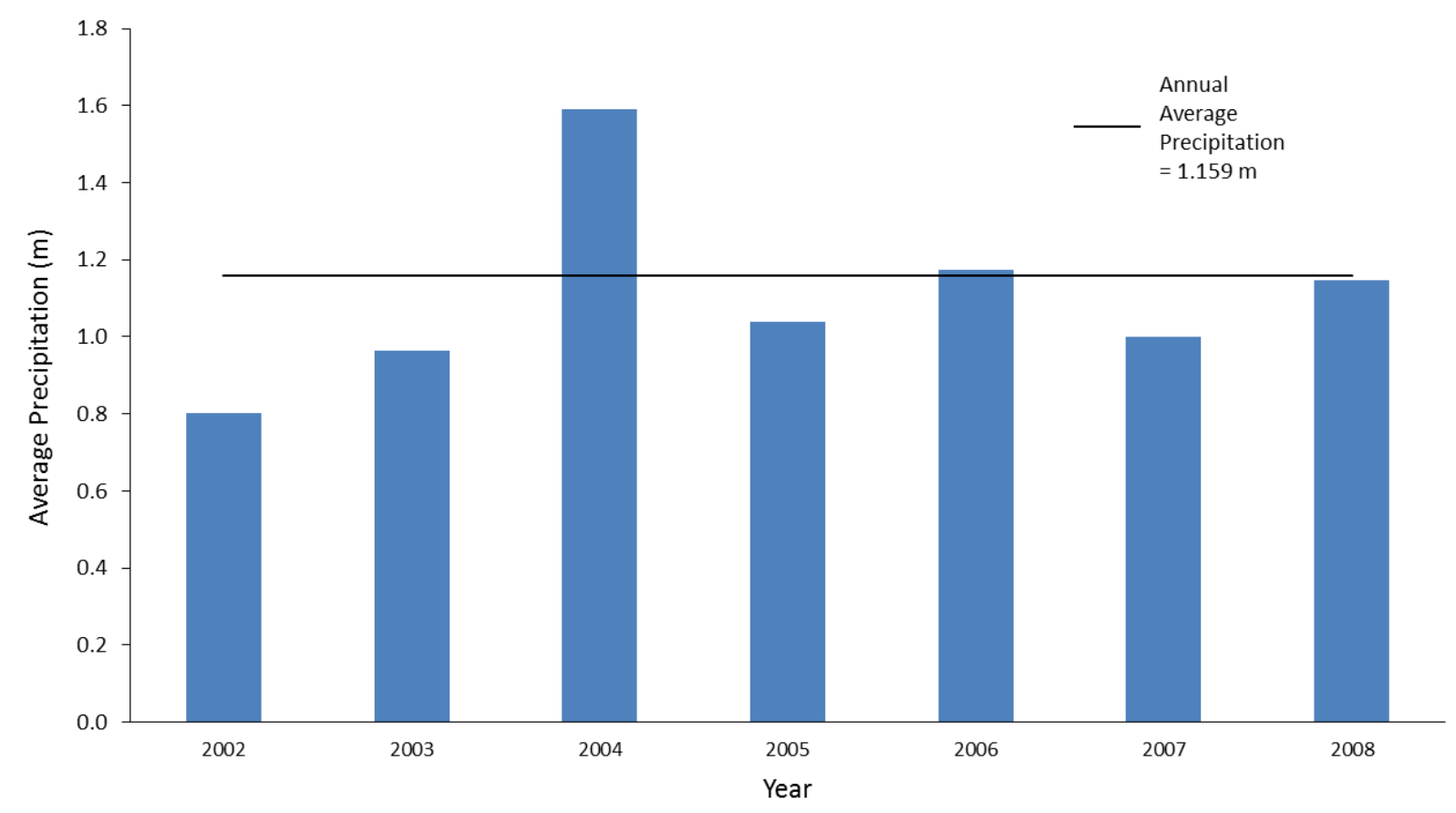

Figure 5.4. Dry Creek average annual hourly precipitation (2002-2008) and historical average precipitation comparison

Calibration followed standard modeling procedures as advised by established criteria (Atkins et al., 2005; Ferrari et al., 2009). The calibration period, June 2000 through December 2004, was simulated with land use parameters from 2001. The error allowances described in Atkins et al. (2005) and Ferrari et al. (2009) (Table 5.2) were used as criteria for model calibration and validation acceptance. 
Table 5.2. HSPF calibration criteria and error allowances

\begin{tabular}{lc}
\hline \multicolumn{1}{c}{ Calibration Criteria } & Limit or Range \\
\hline Total Flow Error (\%) & \pm 10 \\
Lowest 50\% Flow Error (\%) & \pm 10 \\
Highest 10\% Flow Error (\%) & \pm 15 \\
Mean Storm Volume Error (\%) & \pm 15 \\
Mean Storm Peak Flow Error (\%) & \pm 15 \\
Overall Water Balance Error (\%) & $-1.3-32.9^{*}$ \\
Mean Yearly Water Balance Error (\%) & $-2.1-27.8^{*}$ \\
Mean Monthly Water Balance Error $(\%)$ & $0.7-83.9^{*}$ \\
Nash Sutcliffe Efficiency & $0.61-0.78^{* *}$ \\
\hline
\end{tabular}

Note: Adapted from Atkins et al. (2005) and Ferrari et al. (2009)

*Water balance error limits were not specified in Atkins et al. (2005) or Ferrari et al. (2009), so published values of these errors were used

**Nash Sutcliffe Efficiency range from Ferrari et al. (2009) and Kim and Ryu (2014)

Initially, HSPF input parameters were implemented into WinHSPF based on the input parameters used in Atkins et al. (2005) for the USGS Clear Fork station at Clear Fork, WV which is $61 \mathrm{~km}$ from the study watershed. However, calibration errors exceeded allowances, except for the total flow error (Table 5.3; Figure 5.5). Therefore, further calibration of input parameters was completed.

Table 5.3. Initial model run calibration criteria and model run results

\begin{tabular}{lcc}
\hline \multicolumn{1}{c}{ Calibration Criteria } & Limit or Range & $\begin{array}{c}\text { Model } \\
\text { Results }\end{array}$ \\
\hline Total Flow Error & $\pm 10 \%$ & $8.87 \%$ \\
Lowest 50\% Flow Error & $\pm 10 \%$ & $49.70 \%$ \\
Highest 10\% Flow Error & $\pm 15 \%$ & $-23.81 \%$ \\
Mean Storm Volume Error & $\pm 15 \%$ & $15.04 \%$ \\
Mean Storm Peak Flow Error & $\pm 15 \%$ & $32.06 \%$ \\
Overall Water Balance Error & $-1.3-32.9$ & $*$ \\
Mean Yearly Water Balance Error & $-2.1-27.8$ & $*$ \\
Mean Monthly Water Balance Error & $0.7-83.9$ & $*$ \\
Nash Sutcliffe Efficiency & $0.61-0.78$ & 0.53 \\
\hline Water Balance not calculated due to other error allowances not met
\end{tabular}




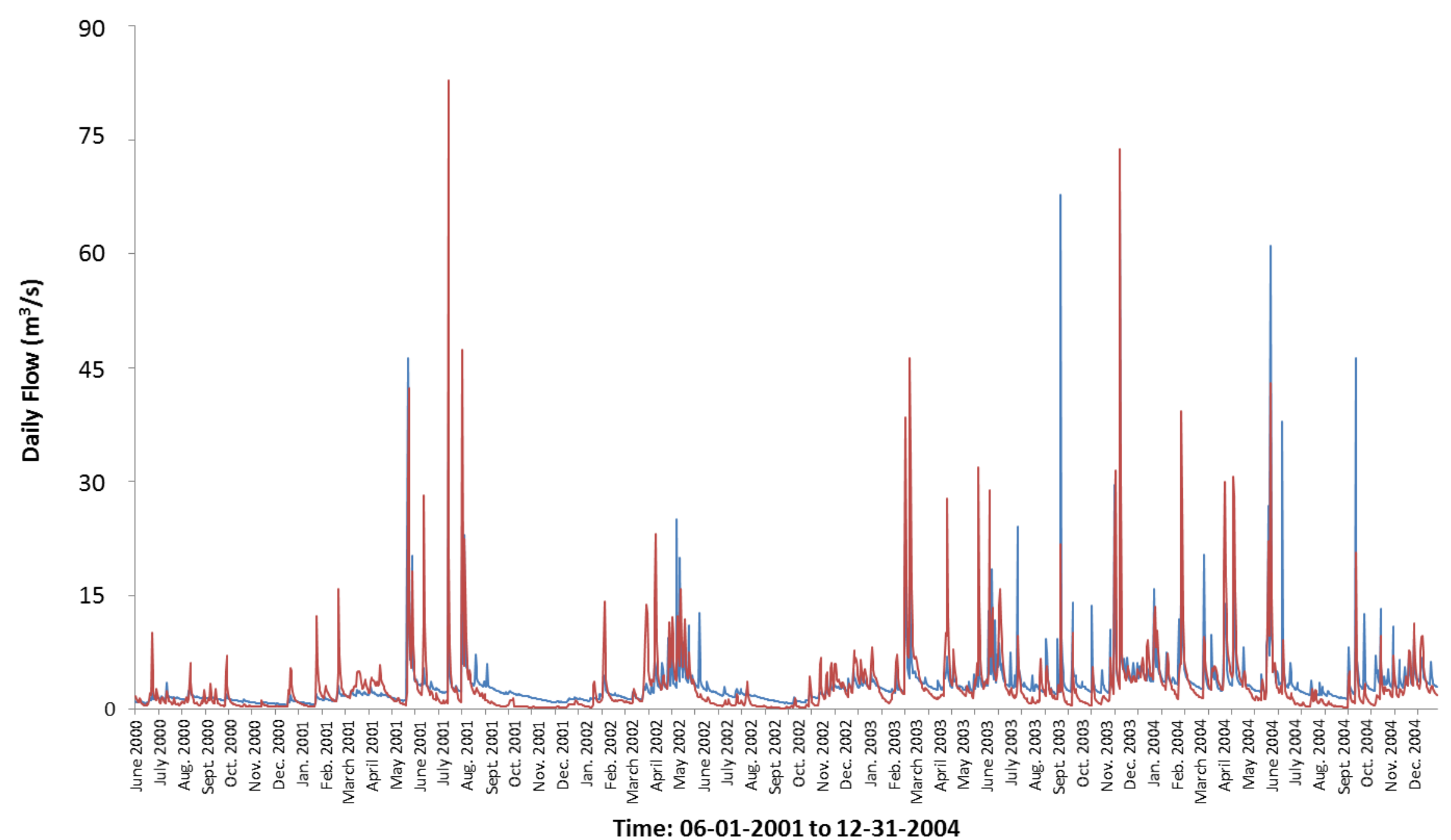

Figure 5.5. Initial model run observed and modeled daily flow comparison (modeled flow in red and observed flow in blue) 
Parameters including AGWRC (groundwater recession rate parameter), CEPSC (interception storage capacity), INFILT (index to the infiltration capacity of the soil), INTFW (interflow inflow parameter), IRC (interflow recession parameter), LSUR (length of the assumed overland flow plane), LZETP (lower zone evapotranspiration parameter), and NSUR (Manning's $\mathrm{n}$ for the overland flow plane) were altered from the initial input values during the calibration process to meet error allowances. The groundwater recession rate parameter, AGWRC, was the ratio of current groundwater discharge to that from 24 hours earlier and was a relatively sensitive calibration parameter (USEPA, 2000). The overall watershed recession rate was a complex function of watershed conditions such as climate, topography, soils, and land use (USEPA, 2000). Both Laroche et al., (1996) and Fontaine and Jacomino (1997) reported a calibrated optimized value of 0.99 which was used as the calibrated AGWRC value for this study.

The amount of rainfall that is retained by vegetation, never reaches the land surface, and is eventually evaporated is known as the interception storage capacity and represented by the very sensitive CEPSC calibration parameter (USEPA, 2000). Typical maximum values for CEPSC grassland $(2.54 \mathrm{~mm})$, cropland $(6.35 \mathrm{~mm})$ and forest $(5.08 \mathrm{~mm})$, provided in Donigian and Davis (1978) were used as the calibrated CEPSC values for this study.

The INFILT parameter was the parameter that effectively controlled the overall division of available moisture from precipitation into surface and subsurface flow and storage components, known as the index to mean soil infiltration rate, and was a fairly sensitive calibration parameter (USEPA, 2000). High values of INFILT produced more water in the lower zone and groundwater resulting in higher baseflow while low values of INFILT produced more upper zone and interflow storage water resulting in greater direct overland flow and interflow (USEPA, 2000). Laroche et al. (1996) described the range of INFILT as 0.10 to $5.84 \mathrm{~mm} / \mathrm{hr}$ while USEPA (2000) listed typical values as 0.25 to $6.35 \mathrm{~mm} / \mathrm{hr}$. These values were used for the calibration process for this study.

The coefficient that determined the amount of water which entered the ground from surface detention storage and became interflow, as opposed to direct overland flow and upper zone storage, was the fairly sensitive calibration parameter INTFW (USEPA, 2000). The INTFW parameter had an influence on storm hydrographs and affected the timing of runoff by affecting the division of water between interflow and surface processes (USEPA, 2000). 
Increasing INTFW increased the amount of interflow and decreased direct overland flow while shifting and delaying the flow to later in time (USEPA, 2000). Decreasing INTFW had the opposite effect on the storm hydrographs. For this study, the INTFW parameter was varied to simulate storm hydrographs based upon the typical and possible values provided by the USEPA (2000).

The interflow recession coefficient parameter, IRC, was the ratio of the current daily interflow discharge to the interflow discharge on the previous day and was documented as a very sensitive calibration parameter by USEPA (2000). IRC affected the rate at which interflow was discharged from storage and affected the hydrograph shape in the recession region of the curve between the peak stormflow and baseflow (USEPA, 2000). The USEPA (2000) listed the maximum values for IRC as 0.3 to 0.85 , which was used for the calibration of this study.

The length of the assumed overland flow plane was the LSUR parameter in this study and approximated the average length of travel form water to reach any drainage path or stream reach and was documented as a relatively insensitive calibration parameter in USEPA (2000). For this study, LSUR was estimated to be $60.93 \mathrm{~m}$ or half of the typical ridge to head-of-channel distance or the typical distance between stream channels (Buckley et al., 2013).

The index to lower zone evapotranspiration or LZETP parameter affected evapotranspiration from the lower zone which symbolized the primary soil moisture storage and root zone of the soil profile and was a relatively sensitive calibration parameter (USEPA, 2000). The USEPA (2000) stated the ranges for LZETP for various vegetation (grassland: 0.4-0.6; forest: 0.6-0.8; barren: 0.1-0.4; and wetlands: 0.6-0.9) and these values were used for the calibration of LZERP in this study.

The NSUR parameter represented the Manning's n for overland flow plane and was documented as a relatively insensitive calibration parameter in USEPA (2000). Manning's n values for overland flow were considerably higher than the more commonly published values for flow through a channel (USEPA, 2000). Typical NSUR values have been determined for different land surface conditions by Donigian and Davis (1978) and Donigian et al. (1983) and were used in the calibration process in this study.

Following the changes in each of the calibration parameters, the HSPF model was run to determine the calibration errors with relation to the error allowances described in Table 5.2. If the model run did not meet the error allowances, calibration parameters were further altered. A 
single calibration parameter was manipulated until maximum model improvement (modeled flow closest to observed flow) was obtained. Then, the next input parameter was manipulated to achieve model improvement. This process continued, resulting in eleven model runs (Appendix C), until each of the calibration error allowances were met (Table 5.4; Table 5.5), indicating a successful model calibration and proper modeling of the study watershed hydrology (Figure 5.6; Figure 5.7).

Table 5.4. Initial and calibrated HSPF model calibration runs parameters

\begin{tabular}{ccccc}
\hline Parameter & Description & Initial & Calibrated & Units \\
\hline AGWRC & groundwater recession rate parameter & 0.038 & $0.038-0.039$ & $1 / \mathrm{mm}$ \\
CEPSC & interception storage capacity & $0-5.16$ & $0.05-5.08^{*}$ & $\mathrm{~mm}$ \\
INFILT & index to the infiltration capacity of the soil & $0.025-4.06$ & 0.04 & $\mathrm{~mm} / \mathrm{day}$ \\
INTFW & interflow inflow parameter & $0.05-2.5$ & 5.5 & none \\
IRC & interflow recession parameter & $0.02-0.1$ & $0.3-0.52^{*}$ & $1 /$ day \\
LSUR & length of the assumed overland flow plane & $15-91$ & 61 & $\mathrm{~m}$ \\
LZETP & lower zone E-T parameter & $0.228-0.402$ & $0.1-0.7 *$ & none \\
NSUR & Manning's n for the overland flow plane & $0.02-0.35$ & $0.2-0.35$ & none \\
\hline
\end{tabular}

Note: Adapted from Ferrari et al. (2009), Additional model inputs in Appendix B

*Parameter varied monthly

Table 5.5. Calibrated model run calibration criteria and model run results

\begin{tabular}{lcc}
\hline \multicolumn{1}{c}{ Calibration Criteria } & Limit or Range & Model Results \\
\hline Total Flow Error & $\pm 10 \%$ & $6.84 \%$ \\
Lowest 50\% Flow Error & $\pm 10 \%$ & $9.33 \%$ \\
Highest 10\% Flow Error & $\pm 15 \%$ & $3.50 \%$ \\
Mean Storm Volume Error & $\pm 15 \%$ & $5.11 \%$ \\
Mean Storm Peak Flow Error & $\pm 15 \%$ & $-0.83 \%$ \\
Overall Water Balance Error & $-1.3-32.9$ & $7.24 \%$ \\
Mean Yearly Water Balance Error & $-2.1-27.8$ & $3.30 \%$ \\
Mean Monthly Water Balance Error & $0.7-83.9$ & $-78.23 \% *$ \\
Nash Sutcliffe Efficiency & $0.61-0.78$ & 0.61 \\
\hline
\end{tabular}

*Excessive mean monthly water balance error due to single day error outlier of $-4941 \%$; Mean monthly water balance $=11.83 \%$ excluding outlier 


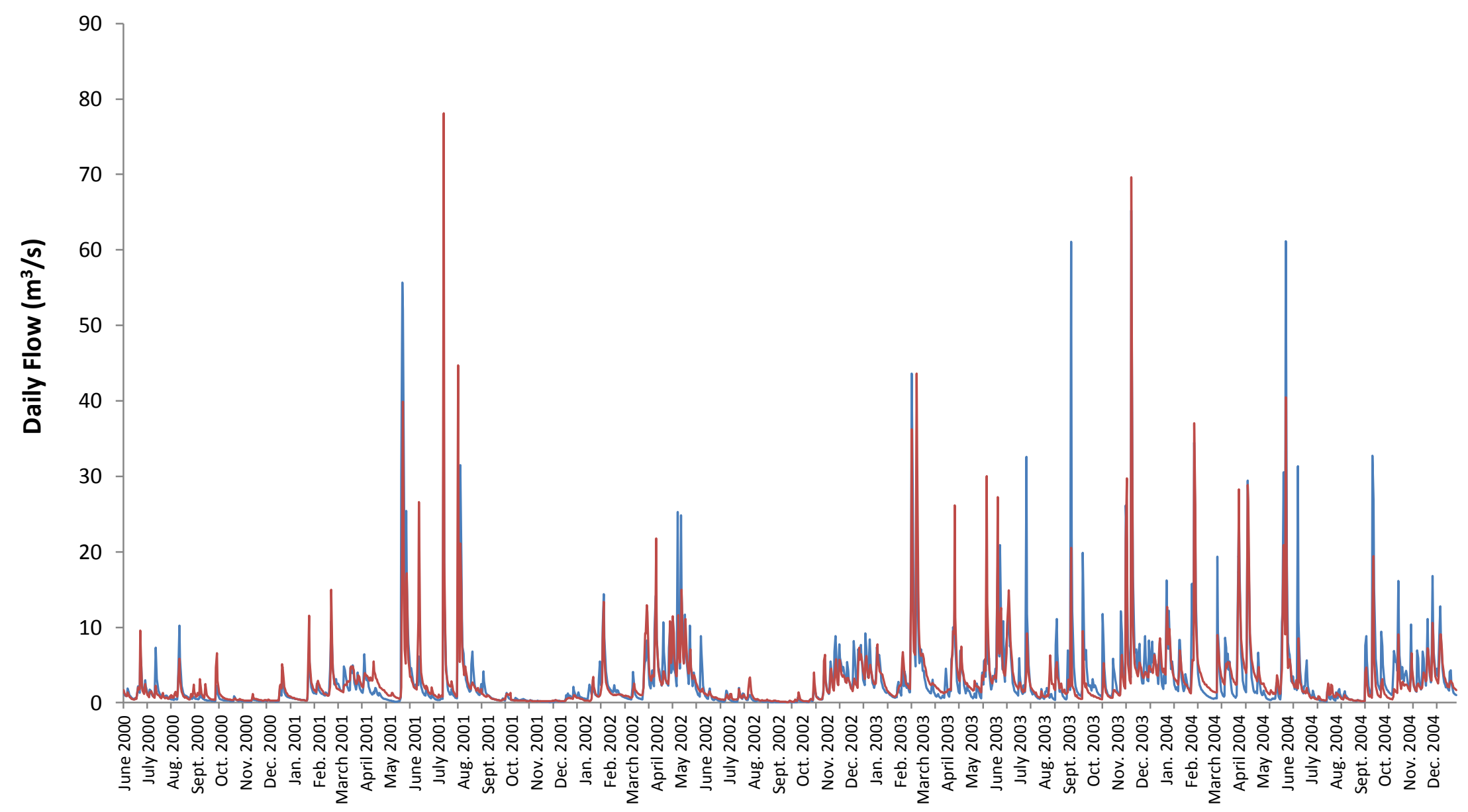

Time: 06-01-2001 to 12-31-2004

Figure 5.6. Calibrated model run observed and modeled daily flow comparison (modeled flow in red and observed flow in blue) 


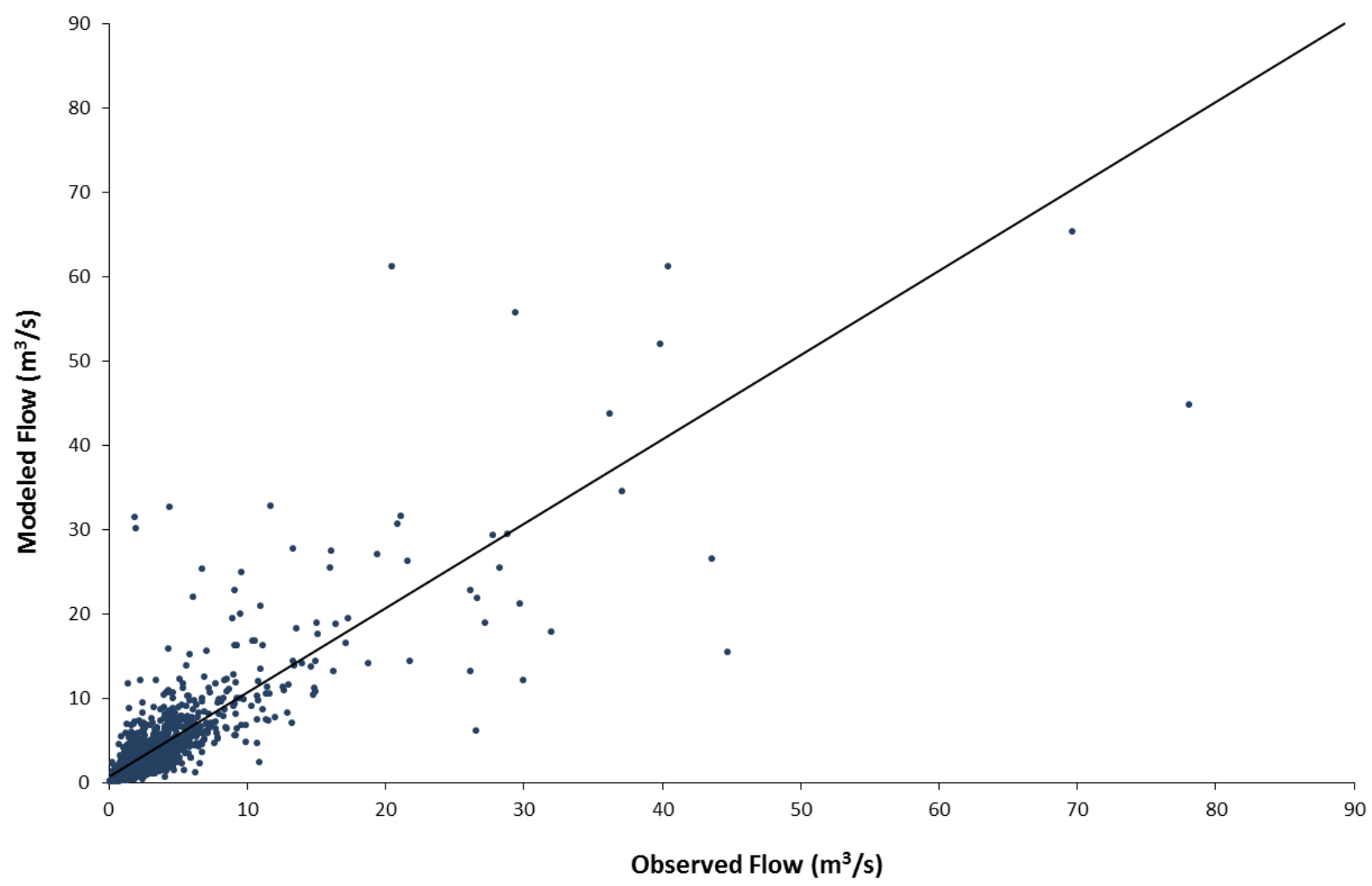

Figure 5.7. Modeled and observed daily flow comparison for HSPF model calibration (2001-2004)

\subsubsection{Model Validation}

The validation process was an extension of the calibration process, and its purpose was to ensure the calibrated model properly assessed all the variables and conditions that could affect model results (Duda et al., 2012). Independently derived discharge data for the USGS station Clear Fork at Whitesville, WV were used for validation of the calibrated HSPF model. The model was validated with the 2006 land-use condition for years 2005-2009, and the same input parameters used for the calibration were used for the validation. The same error allowances described in Table 5.2 were used for the validation process.

All of the error allowances were met with the exception of the lowest $50 \%$ flow error and the Nash Sutcliffe efficiency was lower than similar published literature values (Table 5.6). This error difference could have been attributed in part to the large differences in the average annual 
precipitation for the nine year span compared to the overall historical average annual precipitation of the site (Figure 5.4; 0.80-1.59 $\mathrm{m}$ average annual precipitation for 2002-2008; $1.16 \mathrm{~m}$ historical average annual precipitation). Other probable error difference contributions include comparing a fixed land use (due to HSPF modeling capabilities) to empirical data over a period with non-stationary land use, meteorological data used may not accurately reflect the weather pattern of the watershed due to being located approximately $20.9 \mathrm{~km}$ away from meteorological station, and HSPF relies heavily on calibration and may not adequately reflect watershed processes (Brun and Band, 2000; Ferrari et al., 2009). The validation model (Figure 5.8; Figure 5.9) was accepted because of the error justification.

Table 5.6. Validated model run validation criteria and model run results

\begin{tabular}{lcc}
\hline \multicolumn{1}{c}{ Validation Criteria } & Limit or Range & Model Results \\
\hline Total Flow Error & $\pm 10 \%$ & $3.12 \%$ \\
Lowest 50\% Flow Error & $\pm 10 \%$ & $52.11 \%$ \\
Highest 10\% Flow Error & $\pm 15 \%$ & $-12.93 \%$ \\
Mean Storm Volume Error & $\pm 15 \%$ & $-3.11 \%$ \\
Mean Storm Peak Flow Error & $\pm 15 \%$ & $3.62 \%$ \\
Overall Water Balance Error & $-1.3-32.9$ & $9.74 \%$ \\
Mean Yearly Water Balance Error & $-2.1-27.8$ & $5.74 \%$ \\
Mean Monthly Water Balance Error & $0.7-83.9$ & $25.28 \%$ \\
Nash Sutcliffe Efficiency & $0.61-0.78$ & 0.52 \\
\hline
\end{tabular}




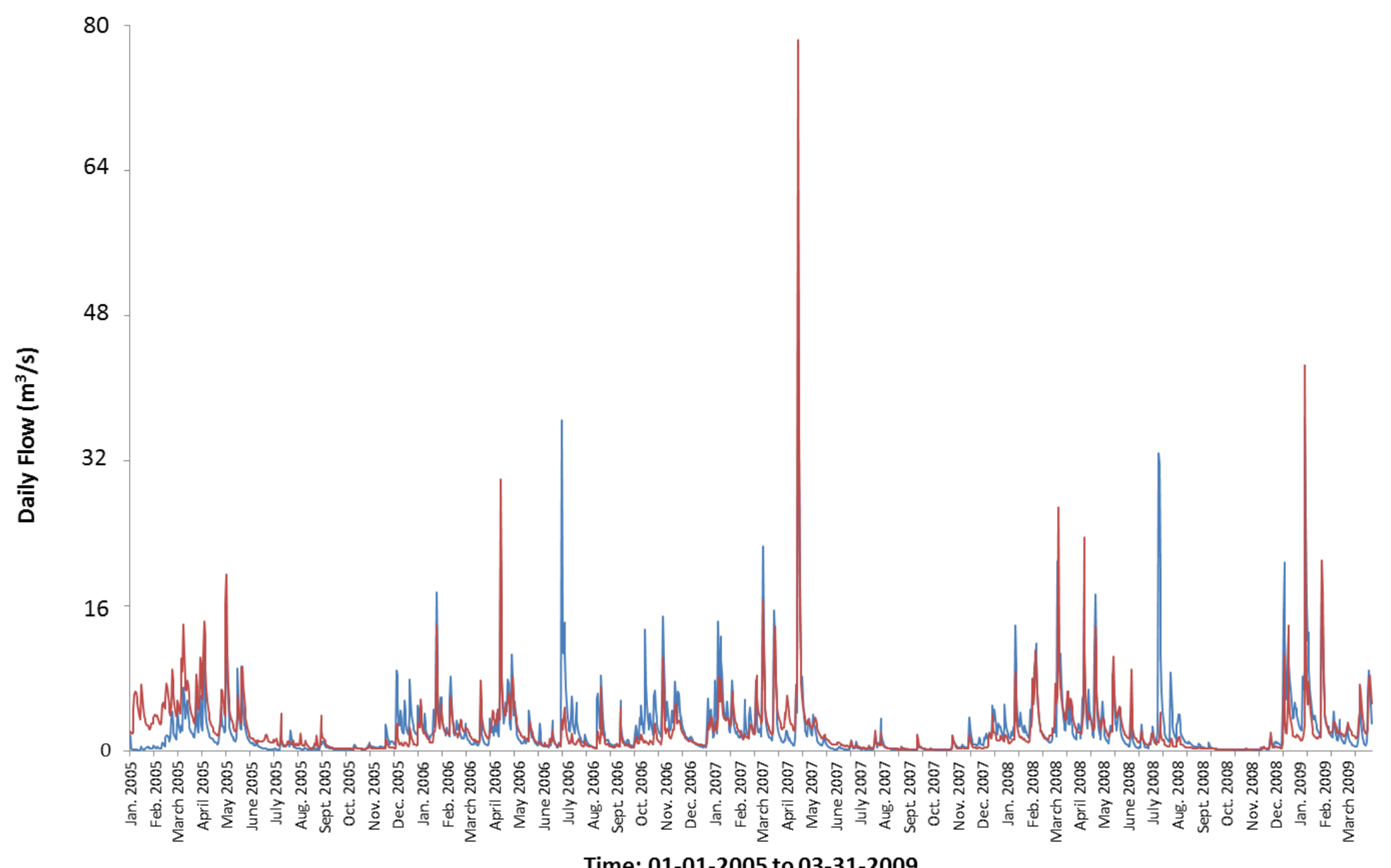

Figure 5.8. Validated model run observed and modeled daily flow comparison (modeled flow in red and observed flow in blue) 


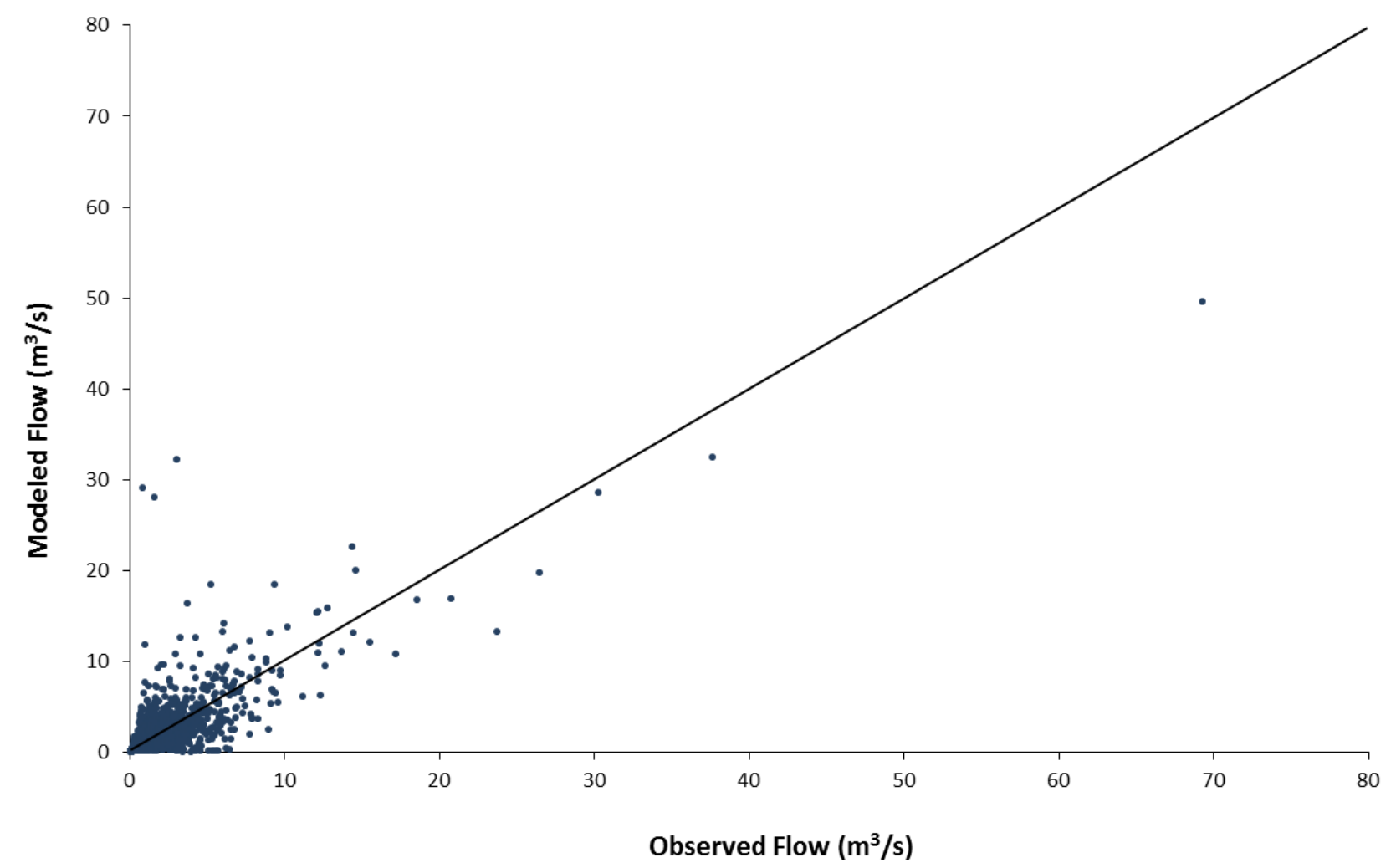

Figure 5.9. Modeled and observed daily flow comparison for HSPF model validation (20052009)

\subsubsection{HSPF Model Predictions}

Five prediction models were performed to estimate the current (2011-2020) and future (2041-2050) hydrologic response of the watershed and included: 1) current hydrologic response given conventionally reclaimed valley fills; 2) current hydrologic response given GLD valley fills; 3) future hydrologic response given conventionally reclaimed valley fills; 4) future hydrologic response given GLD valley fills; and 5) future hydrologic response given no land disturbance occurred in the watershed. Prediction simulations were performed using the nine years of meteorological data available from 2000 to 2009. A nine year span was selected to incorporate a wide variety of atmospheric driving conditions for hydrologic response, specifically for peak flow events (Figure 5.3; Figure 5.4).

HSPF model land use parameters were altered for each prediction scenario to mimic the proposed land use conditions. This research study focused on valley-fill reclamation; therefore, 
only valley-fill areas were altered from one land use condition to another. Mining land use was assumed to become reclaimed land and therefore diminished over time. It was assumed that mining within the watershed would decrease over time as reserves were depleted, but valley fills from past mining would be reclaimed. Therefore, HSPF modeling demonstrated these assumed alteration trends.

Valley fills reclaimed using traditional techniques were estimated to respond similar to grassland, while valley fills reclaimed using geomorphic landform principles were estimated to respond similar to forest (Snyder, 2013). The no land disturbance scenario included modeling all disturbed land as forest, the pre-disturbed land use. Each prediction simulation began with the 2011 estimated land use for the watershed, then the barren, forest, and grassland land uses were altered. All remaining land use areas remained unchanged.

Total flow, lowest 50\% flow, highest $10 \%$ flow, mean storm volume, and mean storm peak flow were calculated for each modeled scenario. Annual storm peak flow was determined by adding all of the flows that occurred when flow increased or if flow increased more than one consecutive day, the maximum flow prior to flow decreasing for each year. The mean storm peak flow was calculated by dividing the sum of the annual storm peak flows by the number of stormflow events. Mean storm volume was determined by adding the calculated volume of flow for each of the annual peak storm events, which were the single peak flow event each year plus the flow for the two consecutive days prior and the five consecutive days after.

The results from prediction scenarios 1 and 2 were compared to determine the current hydrologic impact within the watershed between the two reclamation methods. The percent differences of total flow, lowest $50 \%$ flow, highest $10 \%$ flow, mean storm volume, and mean storm peak flow were calculated using:

$$
D_{\%}=\frac{X_{1, T r a d}-X_{2, G L D}}{X_{2, G L D}}
$$

where $X_{1, \text { Trad }}=$ variable from simulation $1 ; X_{2, \mathrm{GLD}}=$ variable from simulation 2 .

The results from prediction scenarios 3 and 4 were compared to determine the current hydrologic impact within the watershed between the two reclamation methods. The percent differences of total flow, lowest $50 \%$ flow, highest $10 \%$ flow, mean storm volume, and mean storm peak flow were calculated using: 


$$
D_{\%}=\frac{X_{3, T r a d}-X_{4, G L D}}{X_{4, G L D}}
$$

where $X_{3, T r a d}=$ variable from simulation $3 ; X_{4, G L D}=$ variable from simulation 4 .

The results from prediction scenarios 3 and 5 were compared to determine the current hydrologic impact within the watershed between the traditional reclamation method and the no land disturbance scenario. The percent differences of total flow, lowest $50 \%$ flow, highest $10 \%$ flow, mean storm volume, and mean storm peak flow were calculated using:

$$
D_{\%}=\frac{X_{3, T r a d}-X_{5, N L D}}{X_{5, N L D}}
$$

where $X_{3, T r a d}=$ variable from simulation $3 ; X_{5, N L D}=$ variable from simulation 5 .

The results from prediction scenarios 4 and 5 were compared to determine the current hydrologic impact within the watershed between the GLD reclamation method and the no land disturbance scenario. The percent differences of total flow, lowest $50 \%$ flow, highest $10 \%$ flow, mean storm volume, and mean storm peak flow were calculated using:

$$
D_{\%}=\frac{X_{4, G L D}-X_{5, N L D}}{X_{5, N L D}}
$$

where $\mathrm{X}_{4, \mathrm{GLD}}=$ variable from simulation $3 ; \mathrm{X}_{5, \mathrm{NLD}}=$ variable from simulation 5 .

\subsubsection{HSPF Model Predictions 1 and 2}

The first two model predictions performed in HSPF estimated the hydrologic responses of the study watershed in its current land use and land cover condition. Each of the predictions were modeled from 2011 to 2020 and used the total area of constructed valley fills within the watershed in $2014\left(167 \mathrm{~km}^{2}\right)$ for land use input alteration (Fig. 5.10). 


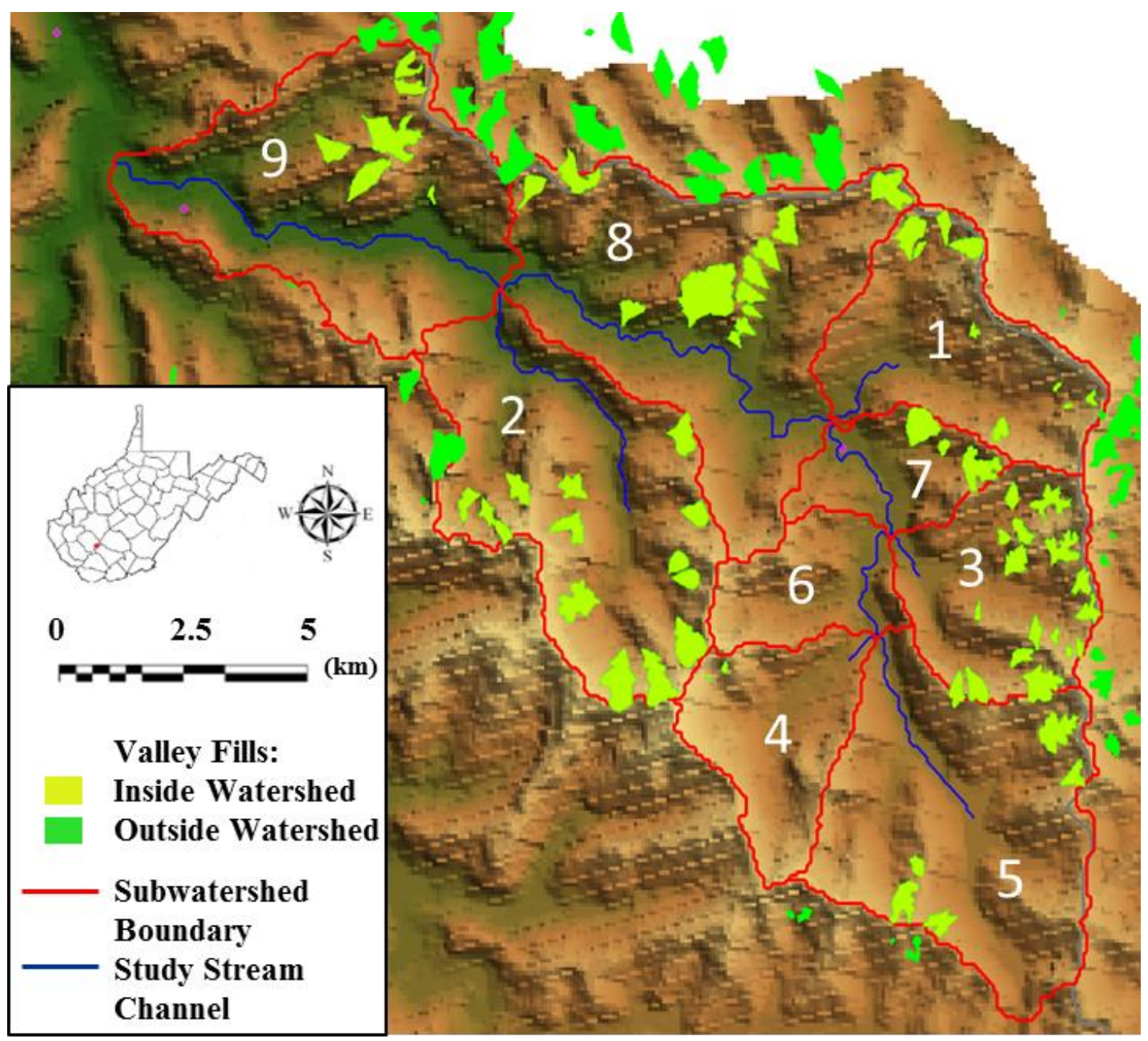

Figure 5.10. Clear Fork experimental watershed, delineated with labeled subwatersheds, and 2014 valley-fill areas

The 2011 land use area inputs were altered for prediction simulations 1 and 2 based on the reclamation technique being modeled, traditional or GLD (Table 5.7). The HSPF scenario of traditional valley-fill reclamation was modeled by changing the valley-fill area within each subwatershed from barren land use to the reclaimed land use of grassland (Snyder, 2013). If the barren land use area was depleted before all of the valley-fill area was subtracted, the remaining valley-fill area was subtracted from the forest land use area, assuming the disturbance occurred after 2011 and was classified as forest land use in 2011 (Table 5.8).

The GLD valley-fill reclamation scenario was modeled using the same land use alteration technique except the barren land use area was changed to the reclaimed land use of forest (Snyder, 2013). If the barren land use area was depleted, the remaining valley-fill area was 
subtracted from grassland, assuming the land had been re-vegetated and was classified as grassland in 2011 (Table 5.9).

Table 5.7. HSPF model predictions 1 (traditional) and 2 (GLD): land use alteration methods

\begin{tabular}{cccccccc}
\hline $\begin{array}{c}\text { Model } \\
\text { Prediction }\end{array}$ & $\begin{array}{c}\text { Meteorological } \\
\text { Data Years }\end{array}$ & $\begin{array}{c}\text { Simulation } \\
\text { Years }\end{array}$ & $\begin{array}{c}\text { VF Area } \\
\text { Date }\end{array}$ & $\begin{array}{c}\text { Land } \\
\text { Use Date }\end{array}$ & $\begin{array}{c}\text { Reclamation } \\
\text { Technique }\end{array}$ & $\begin{array}{c}\text { How Land Use } \\
\text { Was Altered }\end{array}$ & $\begin{array}{c}\text { If Land Use } \\
\text { Depleted }\end{array}$ \\
\hline 1 & $2000-2009$ & $2011-2020$ & 2014 & 2011 & Traditional & $\begin{array}{c}\text { VF area subtracted } \\
\text { from barren and } \\
\text { added to grassland }\end{array}$ & $\begin{array}{c}\text { Remaining VF } \\
\text { area subtracted } \\
\text { from forest }\end{array}$ \\
2 & $2000-2009$ & $2011-2020$ & 2014 & 2011 & GLD & $\begin{array}{c}\text { VF area subtracted } \\
\text { from barren and } \\
\text { added to forest }\end{array}$ & $\begin{array}{c}\text { Remaining VF } \\
\text { area subtracted } \\
\text { from grassland }\end{array}$ \\
\hline
\end{tabular}

Note: $\mathrm{VF}=$ Valley Fill, N/A = Not Applicable, GLD=Geomorphic Landform Design

Table 5.8. HSPF model prediction 1 (traditional): current land use inputs

\begin{tabular}{|c|c|c|c|c|c|c|c|c|c|}
\hline \multicolumn{10}{|c|}{ Model Prediction 1: Traditional 2011-2020, all valley fills grassland } \\
\hline \multirow[b]{2}{*}{ Subwatershed } & \multirow[b]{2}{*}{$\begin{array}{l}\text { Area } \\
\left(\mathbf{k m}^{2}\right)\end{array}$} & \multirow{2}{*}{$\begin{array}{c}\text { Valley Fill } \\
\text { Area } \\
\left(\mathbf{k m}^{\mathbf{2}}\right)\end{array}$} & \multirow{2}{*}{$\begin{array}{l}\text { No. of } \\
\text { Valley } \\
\text { Fills }\end{array}$} & \multicolumn{2}{|c|}{ Barren Area $\left(\mathrm{km}^{2}\right)$} & \multicolumn{2}{|c|}{ Grassland Area $\left(\mathbf{k m}^{2}\right)$} & \multicolumn{2}{|c|}{ Forest Area $\left(\mathrm{km}^{2}\right)$} \\
\hline & & & & 2011 & $\begin{array}{c}\text { Projected } \\
2014\end{array}$ & 2011 & $\begin{array}{c}\text { Projected } \\
2014\end{array}$ & 2011 & $\begin{array}{c}\text { Projected } \\
2014\end{array}$ \\
\hline 1 & 15.70 & 0.72 & 9 & 0.47 & 0.00 & 0.35 & 1.07 & 14.87 & 14.61 \\
\hline 2 & 27.08 & 2.94 & 13 & 0.11 & 0.00 & 12.13 & 15.08 & 14.65 & 11.81 \\
\hline 3 & 13.59 & 1.87 & 17 & 2.02 & 0.15 & 4.49 & 6.35 & 7.09 & 7.09 \\
\hline 4 & 10.70 & 0.02 & 2 & 0.68 & 0.66 & 4.00 & 4.03 & 5.55 & 5.55 \\
\hline 5 & 26.36 & 0.92 & 5 & 0.82 & 0.00 & 2.66 & 3.58 & 22.88 & 22.78 \\
\hline 6 & 7.30 & 0.00 & 0 & 0.12 & 0.12 & 1.22 & 1.22 & 5.86 & 5.86 \\
\hline 7 & 6.63 & 0.67 & 3 & 1.17 & 0.50 & 0.28 & 0.95 & 5.13 & 5.13 \\
\hline 8 & 31.78 & 2.65 & 12 & 1.22 & 0.00 & 14.79 & 17.43 & 15.26 & 13.83 \\
\hline 9 & 27.68 & 1.21 & 6 & 4.04 & 2.83 & 1.63 & 2.85 & 21.31 & 21.31 \\
\hline Total & 166.82 & 11.00 & 67 & 10.64 & 4.26 & 41.57 & 52.56 & 112.60 & 107.99 \\
\hline
\end{tabular}


Table 5.9. HSPF model prediction 2 (GLD): current land use inputs

\begin{tabular}{|c|c|c|c|c|c|c|c|c|c|}
\hline \multicolumn{10}{|c|}{ Model Prediction 2: GLD 2011-2020, all valley fills forested } \\
\hline \multirow[b]{2}{*}{ Subwatershed } & \multirow[b]{2}{*}{$\begin{array}{c}\text { Area } \\
\left(\mathbf{k m}^{2}\right)\end{array}$} & \multirow{2}{*}{$\begin{array}{c}\text { Valley Fill } \\
\text { Area } \\
\left(\mathbf{k m}^{2}\right)\end{array}$} & \multirow{2}{*}{$\begin{array}{c}\text { No. of } \\
\text { Valley } \\
\text { Fills }\end{array}$} & \multicolumn{2}{|c|}{ Barren Area $\left(\mathrm{km}^{2}\right)$} & \multicolumn{2}{|c|}{ Grassland Area $\left(\mathrm{km}^{2}\right)$} & \multicolumn{2}{|c|}{ Forest Area $\left(\mathrm{km}^{2}\right)$} \\
\hline & & & & 2011 & $\begin{array}{c}\text { Projected } \\
2014\end{array}$ & 2011 & $\begin{array}{c}\text { Projected } \\
2014\end{array}$ & 2011 & $\begin{array}{c}\text { Projected } \\
2014\end{array}$ \\
\hline 1 & 15.70 & 0.72 & 9 & 0.47 & 0.00 & 0.35 & 0.10 & 14.87 & 15.59 \\
\hline 2 & 27.08 & 2.94 & 13 & 0.11 & 0.00 & 12.13 & 9.30 & 14.65 & 17.59 \\
\hline 3 & 13.59 & 1.87 & 17 & 2.02 & 0.15 & 4.49 & 4.49 & 7.09 & 8.96 \\
\hline 4 & 10.70 & 0.02 & 2 & 0.68 & 0.66 & 4.00 & 4.00 & 5.55 & 5.58 \\
\hline 5 & 26.36 & 0.92 & 5 & 0.82 & 0.00 & 2.66 & 2.56 & 22.88 & 23.79 \\
\hline 6 & 7.30 & 0.00 & 0 & 0.12 & 0.12 & 1.22 & 1.22 & 5.86 & 5.86 \\
\hline 7 & 6.63 & 0.67 & 3 & 1.17 & 0.50 & 0.28 & 0.28 & 5.13 & 5.80 \\
\hline 8 & 31.78 & 2.65 & 12 & 1.22 & 0.00 & 14.79 & 13.37 & 15.26 & 17.90 \\
\hline 9 & 27.68 & 1.21 & 6 & 4.04 & 2.83 & 1.63 & 1.63 & 21.31 & 22.52 \\
\hline Total & 166.82 & 11.00 & 67 & 10.64 & 4.26 & 41.57 & 36.96 & 112.60 & 123.59 \\
\hline
\end{tabular}

\subsubsection{HSPF Model Predictions 3, 4, and 5}

HSPF model predictions 3, 4, and 5 estimated the hydrologic responses of the study watershed in an estimated future land use and land cover condition of the study watershed. Each of the predictions were modeled from 2041 to 2050. Future valley-fill areas and land use conditions were estimated on the valley-fill construction rate within the watershed. Aerial photography was used to evaluate the year major land use changes began within the study watershed (Google Earth, 2014). Surface mining land disturbance and valley-fill construction began in approximately 1996 within the study watershed, still occurs today, and was projected to occur in the future. The valley-fill construction rate that occurred from 1996 to 2014 was predicted to remain steady for future decades. Therefore, the projected (2050) valley-fill area was estimated to be the current (2014) valley-fill area (WVDEP TAGIS, 2014) for each subwatershed multiplied by three (Table 5.10). 
Table 5.10. Current (2014) and projected (2050) valley-fill areas in experimental subwatersheds

\begin{tabular}{cccc}
\hline \multicolumn{2}{c}{ Subwatershed } & \multicolumn{2}{c}{ Valley Fill Area $\left.\mathbf{( k m}^{\mathbf{2}}\right)$} \\
\hline & Area $\left(\mathbf{k m}^{\mathbf{2}}\right)$ & Current $(\mathbf{2 0 1 4})$ & Projected $(\mathbf{2 0 5 0})$ \\
\hline $\mathbf{1}$ & 15.7 & 0.7 & 2.2 \\
$\mathbf{3}$ & 27.1 & 2.9 & 8.8 \\
$\mathbf{3}$ & 13.6 & 1.9 & 5.6 \\
$\mathbf{4}$ & 10.7 & 0.02 & 0.1 \\
$\mathbf{5}$ & 26.4 & 0.9 & 2.7 \\
$\mathbf{6}$ & 7.3 & 0.0 & 0.0 \\
$\mathbf{7}$ & 6.6 & 0.7 & 2.0 \\
$\mathbf{8}$ & 31.8 & 2.6 & 7.9 \\
$\mathbf{9}$ & 27.7 & 1.2 & 3.6 \\
Total & $\mathbf{1 6 6 . 9}$ & $\mathbf{1 0 . 9}$ & $\mathbf{3 2 . 9}$ \\
\hline
\end{tabular}

The traditional and GLD valley-fill reclamation scenarios 3 and 4 were modeled using the same principles applied for the 2011-2020 prediction models. The 2011 land use area inputs for prediction simulations 3 and 4 were altered based on the reclamation technique modeled, traditional or GLD, or if no land disturbance occurred (Table 5.11). The traditional reclamation model land use inputs were altered by changing the predicted valley-fill area from barren to grassland. If the barren land use area was depleted, the remaining valley-fill area was subtracted from the forest area, assuming the disturbance occurred after 2011 and was classified as forest land use in 2011 (Table 5.12). The GLD reclamation model land use inputs were altered by changing the predicted valley-fill area from barren to forest. If the barren land use area was depleted, the remaining valley-fill area was subtracted from grassland, assuming the land had been re-vegetated and was classified as grassland in 2011 (Table 5.13). 
Table 5.11. HSPF model predictions 3 (traditional) and 4 (GLD): land use alteration methods

\begin{tabular}{cccccccc}
\hline $\begin{array}{c}\text { Model } \\
\text { Prediction }\end{array}$ & $\begin{array}{c}\text { Meteorological } \\
\text { Data Years }\end{array}$ & $\begin{array}{c}\text { Simulation } \\
\text { Years }\end{array}$ & $\begin{array}{c}\text { VF Area } \\
\text { Date }\end{array}$ & $\begin{array}{c}\text { Land } \\
\text { Use Date }\end{array}$ & $\begin{array}{c}\text { Reclamation } \\
\text { Technique }\end{array}$ & $\begin{array}{c}\text { How Land Use } \\
\text { Was Altered }\end{array}$ & $\begin{array}{c}\text { If Land Use } \\
\text { Depleted }\end{array}$ \\
\hline 3 & $2000-2009$ & $2041-2050$ & $\begin{array}{c}\text { Projected } \\
2050\end{array}$ & 2011 & Traditional & $\begin{array}{c}\text { VF area subtracted } \\
\text { from barren and } \\
\text { added to grassland }\end{array}$ & $\begin{array}{c}\text { Remaining VF } \\
\text { area subtracted } \\
\text { from forest }\end{array}$ \\
4 & $2000-2009$ & $2041-2050$ & $\begin{array}{c}\text { Projected } \\
2050\end{array}$ & 2011 & GLD & $\begin{array}{c}\text { VF area subtracted } \\
\text { from barren and } \\
\text { added to forest }\end{array}$ & $\begin{array}{c}\text { Remaining VF } \\
\text { area subtracted } \\
\text { from grassland }\end{array}$ \\
\hline
\end{tabular}

Note: $\mathrm{VF}=$ Valley Fill, N/A = Not Applicable, GLD=Geomorphic Landform Design

Table 5.12. HSPF model prediction 3: land use inputs

\begin{tabular}{|c|c|c|c|c|c|c|c|c|}
\hline \multicolumn{9}{|c|}{ Model Prediction 3: Traditional 2041-2050, all valley fills grassland } \\
\hline \multirow[b]{2}{*}{ Subwatershed } & \multirow[b]{2}{*}{$\begin{array}{l}\text { Area } \\
\left(\mathbf{k m}^{2}\right)\end{array}$} & \multirow[b]{2}{*}{$\begin{array}{l}\text { Valley Fill } \\
\text { Area }\left(\mathbf{k m}^{2}\right)\end{array}$} & \multicolumn{2}{|c|}{ Barren Area $\left(\mathrm{km}^{2}\right)$} & \multicolumn{2}{|c|}{ Grassland Area $\left(\mathrm{km}^{2}\right)$} & \multicolumn{2}{|c|}{ Forest Area $\left(\mathbf{k m}^{2}\right)$} \\
\hline & & & 2011 & $\begin{array}{c}\text { Projected } \\
2014\end{array}$ & 2011 & $\begin{array}{c}\text { Projected } \\
2014\end{array}$ & 2011 & $\begin{array}{c}\text { Projected } \\
2014\end{array}$ \\
\hline 1 & 15.70 & 2.16 & 0.47 & 0.00 & 0.35 & 2.51 & 14.87 & 13.17 \\
\hline 2 & 27.08 & 8.83 & 0.11 & 0.00 & 12.13 & 20.96 & 14.65 & 5.93 \\
\hline 3 & 13.59 & 5.60 & 2.02 & 0.00 & 4.49 & 10.09 & 7.09 & 3.51 \\
\hline 4 & 10.70 & 0.07 & 0.68 & 0.61 & 4.00 & 4.08 & 5.55 & 5.55 \\
\hline 5 & 26.36 & 2.75 & 0.82 & 0.00 & 2.66 & 5.41 & 22.88 & 20.94 \\
\hline 6 & 7.30 & 0.00 & 0.12 & 0.12 & 1.22 & 1.22 & 5.86 & 5.86 \\
\hline 7 & 6.63 & 2.01 & 1.17 & 0.00 & 0.28 & 2.29 & 5.13 & 4.30 \\
\hline 8 & 31.78 & 7.94 & 1.22 & 0.00 & 14.79 & 22.73 & 15.26 & 8.54 \\
\hline 9 & 27.68 & 3.63 & 4.04 & 0.41 & 1.63 & 5.27 & 21.31 & 21.31 \\
\hline Total & 166.82 & 32.99 & 10.64 & 1.14 & 41.57 & 74.55 & 112.60 & 89.12 \\
\hline
\end{tabular}


Table 5.13. HSPF model prediction 4: land use inputs

\begin{tabular}{|c|c|c|c|c|c|c|c|c|}
\hline \multicolumn{9}{|c|}{ Model Prediction 4: GLD 2041-2050, all valley fills forested } \\
\hline \multirow[b]{2}{*}{ Subwatershed } & \multirow[b]{2}{*}{$\begin{array}{l}\text { Area } \\
\left(\mathbf{k m}^{2}\right)\end{array}$} & \multirow[b]{2}{*}{$\begin{array}{l}\text { Valley Fill } \\
\text { Area }\left(\mathbf{k m}^{2}\right)\end{array}$} & \multicolumn{2}{|c|}{ Barren Area $\left(\mathrm{km}^{2}\right)$} & \multicolumn{2}{|c|}{ Grassland Area $\left(\mathrm{km}^{2}\right)$} & \multicolumn{2}{|c|}{ Forest Area $\left(\mathrm{km}^{2}\right)$} \\
\hline & & & 2011 & $\begin{array}{c}\text { Projected } \\
2014\end{array}$ & 2011 & $\begin{array}{c}\text { Projected } \\
2014\end{array}$ & 2011 & $\begin{array}{c}\text { Projected } \\
2014\end{array}$ \\
\hline 1 & 15.70 & 2.16 & 0.47 & 0.00 & 0.35 & 0.00 & 14.87 & 15.69 \\
\hline 2 & 27.08 & 8.83 & 0.11 & 0.00 & 12.13 & 3.41 & 14.65 & 23.48 \\
\hline 3 & 13.59 & 5.60 & 2.02 & 0.00 & 4.49 & 0.91 & 7.09 & 12.69 \\
\hline 4 & 10.70 & 0.07 & 0.68 & 0.61 & 4.00 & 4.00 & 5.55 & 5.62 \\
\hline 5 & 26.36 & 2.75 & 0.82 & 0.00 & 2.66 & 0.73 & 22.88 & 25.62 \\
\hline 6 & 7.30 & 0.00 & 0.12 & 0.12 & 1.22 & 1.22 & 5.86 & 5.86 \\
\hline 7 & 6.63 & 2.01 & 1.17 & 0.00 & 0.28 & 0.00 & 5.13 & 6.58 \\
\hline 8 & 31.78 & 7.94 & 1.22 & 0.00 & 14.79 & 8.07 & 15.26 & 23.19 \\
\hline 9 & 27.68 & 3.63 & 4.04 & 0.41 & 1.63 & 1.63 & 21.31 & 24.95 \\
\hline Total & 166.82 & 32.99 & 10.64 & 1.14 & 41.57 & 19.99 & 112.60 & 143.68 \\
\hline
\end{tabular}

The 2011 land use area inputs for prediction simulation 5 was altered based on if no land disturbance had occurred within the watershed (Table 5.14). The HSPF scenario of no land disturbance was modeled by altering the barren, grassland, and forest land use areas within each subwatershed. All of the barren and grassland areas were depleted and added to the forest area to simulate no land disturbance had occurred within the study watershed through 2050 (Table 5.15).

Table 5.14. HSPF model prediction 5: land use alteration

\begin{tabular}{cccccccc}
\hline $\begin{array}{c}\text { Model } \\
\text { Prediction }\end{array}$ & $\begin{array}{c}\text { Meteorological } \\
\text { Data Years }\end{array}$ & $\begin{array}{c}\text { Simulation } \\
\text { Years }\end{array}$ & $\begin{array}{c}\text { VF Area } \\
\text { Date }\end{array}$ & $\begin{array}{c}\text { Land } \\
\text { Use Date }\end{array}$ & $\begin{array}{c}\text { Reclamation } \\
\text { Technique }\end{array}$ & $\begin{array}{c}\text { How Land Use } \\
\text { Was Altered }\end{array}$ & $\begin{array}{c}\text { If Land Use } \\
\text { Depleted }\end{array}$ \\
\hline 5 & $2000-2009$ & $2041-2050$ & N/A & 2011 & N/A & $\begin{array}{c}\text { All barren and } \\
\text { grassland depleted } \\
\text { and added to forest }\end{array}$ & N/A \\
\hline
\end{tabular}

Note: $\mathrm{VF}=$ Valley Fill, N/A = Not Applicable 
Table 5.15. HSPF model prediction 5: land use inputs

\begin{tabular}{|c|c|c|c|c|c|c|c|c|}
\hline \multicolumn{9}{|c|}{ Model Prediction 5: NLD 2041-2050, no barren or grassland, all forest } \\
\hline \multirow[b]{2}{*}{ Subwatershed } & \multirow[b]{2}{*}{$\begin{array}{c}\text { Area } \\
\left(\mathbf{k m}^{2}\right)\end{array}$} & \multirow[b]{2}{*}{$\begin{array}{l}\text { Valley Fill } \\
\text { Area }\left(\mathbf{k m}^{2}\right)\end{array}$} & \multicolumn{2}{|c|}{ Barren Area $\left(\mathrm{km}^{2}\right)$} & \multicolumn{2}{|c|}{ Grassland Area $\left(\mathrm{km}^{2}\right)$} & \multicolumn{2}{|c|}{ Forest Area $\left(\mathrm{km}^{2}\right)$} \\
\hline & & & 2011 & $\begin{array}{c}\text { Projected } \\
2014\end{array}$ & 2011 & $\begin{array}{c}\text { Projected } \\
2014\end{array}$ & 2011 & $\begin{array}{c}\text { Projected } \\
2014\end{array}$ \\
\hline 1 & 15.70 & 0.00 & 0.47 & 0.00 & 0.35 & 0.00 & 14.87 & 15.69 \\
\hline 2 & 27.08 & 0.00 & 0.11 & 0.00 & 12.13 & 0.00 & 14.65 & 26.89 \\
\hline 3 & 13.59 & 0.00 & 2.02 & 0.00 & 4.49 & 0.00 & 7.09 & 13.59 \\
\hline 4 & 10.70 & 0.00 & 0.68 & 0.00 & 4.00 & 0.00 & 5.55 & 10.24 \\
\hline 5 & 26.36 & 0.00 & 0.82 & 0.00 & 2.66 & 0.00 & 22.88 & 26.36 \\
\hline 6 & 7.30 & 0.00 & 0.12 & 0.00 & 1.22 & 0.00 & 5.86 & 7.21 \\
\hline 7 & 6.63 & 0.00 & 1.17 & 0.00 & 0.28 & 0.00 & 5.13 & 6.58 \\
\hline 8 & 31.78 & 0.00 & 1.22 & 0.00 & 14.79 & 0.00 & 15.26 & 31.27 \\
\hline 9 & 27.68 & 0.00 & 4.04 & 0.00 & 1.63 & 0.00 & 21.31 & 26.99 \\
\hline Total & 166.82 & 0.00 & 10.64 & 0.00 & 41.57 & 0.00 & 112.60 & 164.81 \\
\hline
\end{tabular}

\subsection{Results}

\subsubsection{HSPF Model Evaluation}

Calibration (2000-2004) and validation (2005-2009) of the Clear Fork watershed HSPF model resulted in similar Nash Sutcliffe efficiency (NSE) and daily flow errors (Table 5.5: NSE=0.61; Table 5.6: NSE=0.52). The observed and modeled data for the seven year simulation period (2001-2008) were compared with observations using log Pearson III flood frequency analysis (Table 5.16; Figure 5.11). Data from simulation years 2000 and 2009 were excluded due to lack of full year data availability. Observed and modeled annual peak stormflows were used to determine 2-, 5-, 10-, 25-, 50-, 100-, and 200-yr stormflows for the experimental watershed. Stormflow trends were similar for the observed and modeled simulations (Figure 5.11). 
Table 5.16. Flood frequency calculations using log-Pearson type III analysis for observed and modeled simulations

\begin{tabular}{ccccc}
\hline & \multicolumn{2}{c}{ Observed } & \multicolumn{2}{c}{ Modeled } \\
\hline $\begin{array}{c}\text { Return } \\
\text { Period } \\
\text { (Years) }\end{array}$ & $\begin{array}{c}\text { Skew } \\
\text { Coefficient } \\
\text { K(0.1506) }\end{array}$ & $\begin{array}{c}\text { Discharge } \\
\mathbf{Q}\left(\mathbf{m}^{3} / \mathbf{s}\right)\end{array}$ & $\begin{array}{c}\text { Skew Coefficient } \\
\text { K(-0.0815) }\end{array}$ & $\begin{array}{c}\text { Discharge } \\
\mathbf{Q}\left(\mathbf{m}^{3} / \mathbf{s}\right)\end{array}$ \\
\hline $\mathbf{2}$ & -0.025 & 0.0 & 0.003 & 0.1 \\
$\mathbf{5}$ & 0.833 & 19.6 & 0.843 & 21.1 \\
$\mathbf{1 0}$ & 1.297 & 547.6 & 1.280 & 485.5 \\
$\mathbf{2 5}$ & 1.802 & 20572.7 & 1.745 & 13647.5 \\
$\mathbf{5 0}$ & 2.133 & 222381.6 & 2.044 & 117138.5 \\
$\mathbf{1 0 0}$ & 2.436 & 1959191.3 & 2.312 & 803759.2 \\
$\mathbf{2 0 0}$ & 2.717 & 14686882.7 & 2.559 & 4709418.6 \\
\hline
\end{tabular}

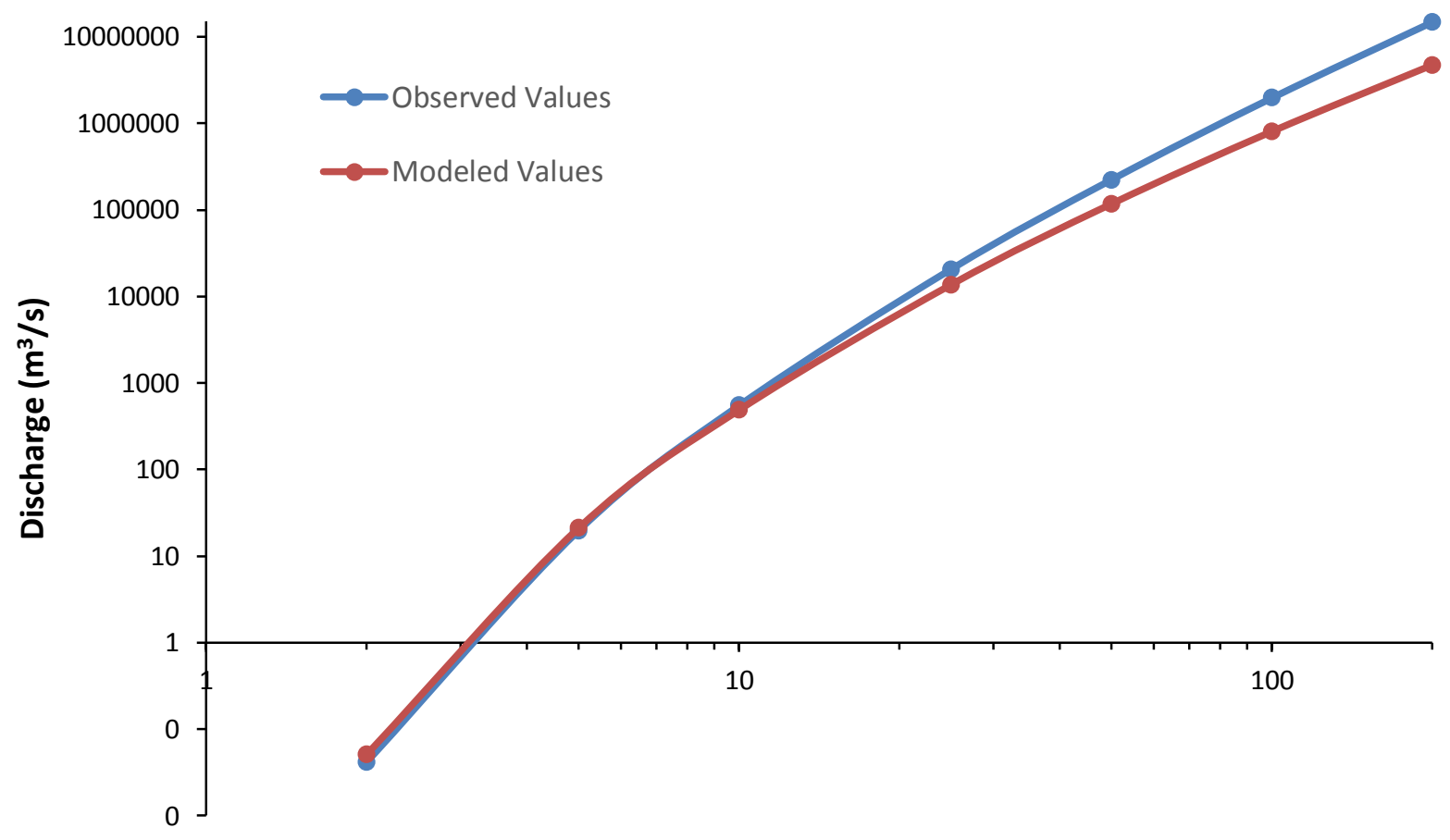

Return Period (yrs)

Figure 5.11. Flood frequency analysis for Clear Fork watershed using log-Pearson type III analysis using observed and modeled annual peak stormflow values (log-log scale) 


\subsubsection{HSPF Prediction Model Results}

The HSPF model predicted the hydrologic impact of altering the traditional valley-fill reclamation to the innovative geomorphic landform reclamation approach. Five hydrologic response prediction simulations were completed, 1) current hydrologic response given conventionally reclaimed valley fills; 2) current hydrologic response given GLD valley fills; 3 ) future hydrologic response given conventionally reclaimed valley fills; 4) future hydrologic response given GLD valley fills; and 5) future hydrologic response given no land disturbance occurred in the watershed, and the results were compared based on reclamation type and time frame.

\subsubsection{HSPF Prediction Model Results: Predictions 1 and 2}

Model simulations 1 and 2 predicted the current hydrologic responses within the study watershed for GLD valley-fill reclamation and traditional reclamation methods (Figure 5.12). Results indicated no substantial difference $(<1.1 \%$ difference) in daily flow or volume when the two valley-fill reclamation techniques were compared. The total flow, lowest $50 \%$ flow, highest $10 \%$ flow, mean storm volume, and mean storm peak flow were lower $(-0.27 \%$ to $-1.10 \%$ difference) for the watershed when geomorphic valley-fill reclamation was modeled as opposed to conventional valley-fill reclamation (Table 5.17). 


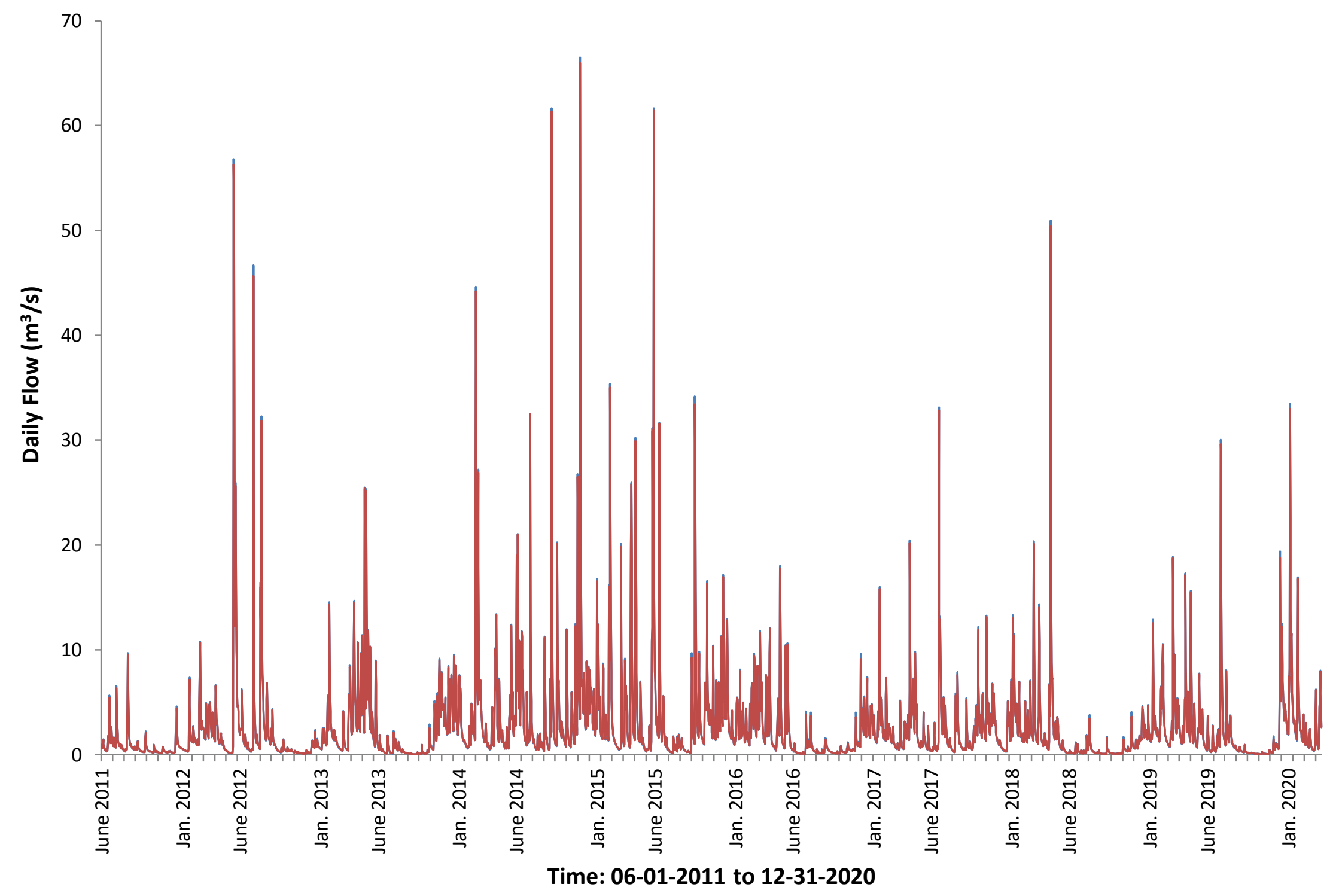

Figure 5.12. Model predictions 1 and 2 daily flow comparison for 2011-2020 (traditional flow in blue and GLD flow in red) 


\section{Table 5.17. Model predictions 1 (traditional) and 2 (GLD) comparison}

\begin{tabular}{cc}
\hline Prediction Criteria & D $\%$ \\
\hline Total Flow & -0.57 \\
Lowest $50 \%$ Flow & -0.27 \\
Highest $10 \%$ Flow & -0.85 \\
Mean Storm Volume & -0.67 \\
Mean Storm Peak Flow & -1.10 \\
Note: $\mathrm{D}_{\%}=\left(\mathrm{X}_{1, \mathrm{Trad}}-\mathrm{X}_{2, \mathrm{GLD}}\right) / \mathrm{X}_{2, \mathrm{GLD}} ;$ where $\mathrm{X}_{1, \text { Trad }}=$ variable \\
from simulation $1 ; \mathrm{X}_{2, \mathrm{GLD}}=$ variable from simulation 2
\end{tabular}

Flood frequency analysis was performed for the prediction scenarios compared to the observed values (Table 5.18; Figure 5.13). Observed annual peak stormflow values, using daily flow data, were used to determine 5-, 10-, 25-, 50-, 100-, and 200-year stormflows for the experimental watershed. Predicted annual peak stormflow values, from daily flow data, were used to predict the same year stormflows for model predictions 1 and 2. No substantial difference $\left(0-18 \mathrm{~m}^{3} / \mathrm{s}\right)$ resulted among the traditional and GLD predicted 5-, 10-, 25-, and 50-yr stormflows. However, the GLD 100- and 200-yr stormsflows were substantial higher than the traditional stormflows (100-yr: $90.1 \mathrm{~m} 3 / \mathrm{s}$ difference; 200-yr: $368.1 \mathrm{~m} 3 / \mathrm{s}$ difference) (Table 5.18). Flood discharge trends were similar for the observed, current traditional, and current GLD simulations (Figure 5.13). 
Table 5.18. Flood frequency calculations using log-Pearson type III analysis for observed and model predictions 1 (traditional) and 2 (GLD)

\begin{tabular}{ccccccc}
\hline & \multicolumn{2}{c}{ Observed } & \multicolumn{2}{c}{ Traditional } & \multicolumn{2}{c}{ GLD } \\
\hline $\begin{array}{c}\text { Return } \\
\text { Period } \\
\text { (Years) }\end{array}$ & $\begin{array}{c}\text { Skew } \\
\text { Coefficient } \\
\text { K(0.1506) }\end{array}$ & $\begin{array}{c}\text { Discharge } \\
\left(\mathbf{m}^{3} / \mathbf{s}\right)\end{array}$ & $\begin{array}{c}\text { Skew Coefficient } \\
\text { K(-0.1747) }\end{array}$ & $\begin{array}{c}\text { Discharge } \\
\left(\mathbf{m}^{3} / \mathbf{s}\right)\end{array}$ & $\begin{array}{c}\text { Skew } \\
\text { Coefficient } \\
\text { K(-0.1747) }\end{array}$ & $\begin{array}{c}\text { Discharge } \\
\left(\mathbf{m}^{3} / \mathbf{s}\right)\end{array}$ \\
\hline $\mathbf{5}$ & 0.833 & 19.6 & 0.855 & 23.1 & 0.855 & 23.1 \\
$\mathbf{1 0}$ & 1.297 & 547.6 & 1.225 & 327.4 & 1.225 & 327.5 \\
$\mathbf{2 5}$ & 1.802 & 20572.7 & 1.590 & 4505.2 & 1.590 & 4507.8 \\
$\mathbf{5 0}$ & 2.133 & 222381.6 & 1.811 & 21961.9 & 1.811 & 21979.9 \\
$\mathbf{1 0 0}$ & 2.436 & 1959191.3 & 1.999 & 84725.2 & 1.999 & 84815.3 \\
$\mathbf{2 0 0}$ & 2.717 & 14686882.7 & 2.163 & 275496.4 & 2.163 & 275864.5 \\
\hline
\end{tabular}

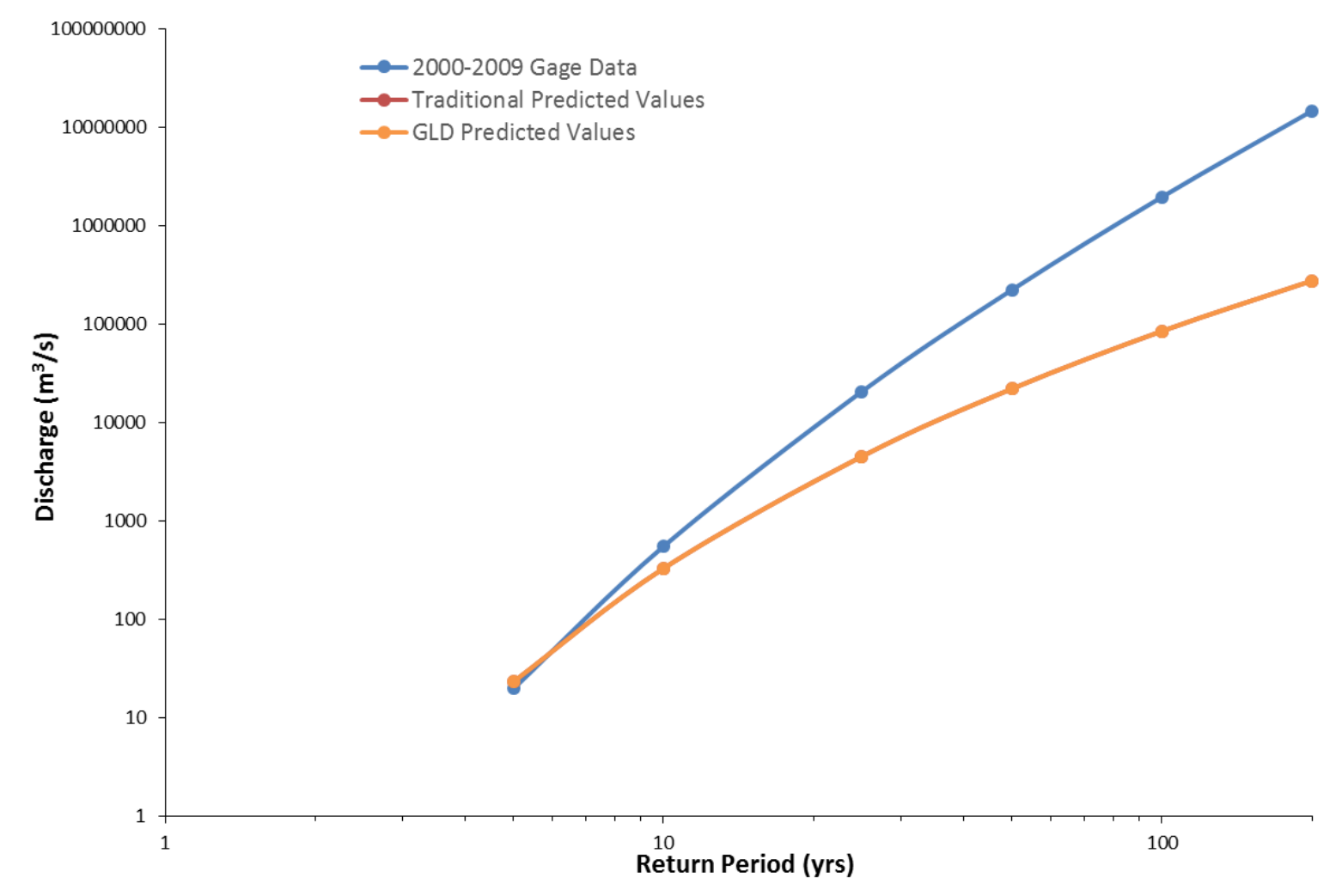

Figure 5.13. Flood frequency analysis for Clear Fork watershed using log-Pearson type III analysis using observed, current traditional predicted, and current GLD predicted annual peak stormflow values $(\log -\log$ scale) 
Average annual flows, annual peak stormflows, and average daily flow ranges were analyzed for prediction models 1 (traditional) and 2 (GLD). Average annual flows, based on daily flow values, were slightly reduced $\left(0.1-0.2 \mathrm{~m}^{3} / \mathrm{s}\right)$ for the GLD prediction compared to the conventional prediction. Average annual flows over the nine year model varied substantially (2011: $0.84-0.86 \mathrm{~m}^{3} / \mathrm{s} ; 2014: 4.52-4.53 \mathrm{~m}^{3} / \mathrm{s}$ ) (Table 5.19).

Estimated GLD annual peak stormflows were $0.07-0.57 \mathrm{~m}^{3} / \mathrm{s}$ lower than the traditional simulation. Annual peak stormflows from one year to another varied greatly. Estimated peak stormflow for 2011 was $9.69 \mathrm{~m}^{3} / \mathrm{s}$ for the traditional reclamation and $9.48 \mathrm{~m}^{3} / \mathrm{s}$ for the GLD reclamation. However, the 2014 peak stormflow was estimated to be $66.49 \mathrm{~m}^{3} / \mathrm{s}$ for the traditional reclamation and $65.98 \mathrm{~m}^{3} / \mathrm{s}$ for the GLD scenario (Table 5.19).

Average daily flow ranges indicated no substantial difference $\left(0-0.57 \mathrm{~m}^{3} / \mathrm{s}\right)$ among traditional and GLD conditions when compared to one another on a yearly basis. However, daily flow ranges varied substantially between years, as demonstrated by significant differences in peak stormflows over the nine year period (Traditional: 9.69-66.49 $\mathrm{m}^{3} / \mathrm{s}$; GLD: $9.48-65.98 \mathrm{~m}^{3} / \mathrm{s}$ ). Minimum daily flows remained relatively constant $\left(0-0.37 \mathrm{~m}^{3} / \mathrm{s}\right)$ throughout the nine year simulation for both reclamation practices (Table 5.19).

Table 5.19. Model predictions 1 (traditional) and 2 (GLD) average annual flow, annual peak stormflow, and average daily flow range

\begin{tabular}{|c|c|c|c|c|c|c|c|}
\hline \multirow[b]{2}{*}{ Year } & \multicolumn{2}{|c|}{ Average Annual Flow } & \multicolumn{3}{|c|}{ Annual Peak Stormflow } & \multicolumn{2}{|c|}{ Average Daily Flow Range } \\
\hline & $\begin{array}{c}\text { Traditional } \\
\left(\mathrm{m}^{3} / \mathrm{s}\right)\end{array}$ & $\begin{array}{l}\text { GLD } \\
\left(\mathrm{m}^{3} / \mathrm{s}\right)\end{array}$ & $\begin{array}{c}\text { Traditional } \\
\left(\mathrm{m}^{3} / \mathrm{s}\right)\end{array}$ & $\begin{array}{c}\text { GLD } \\
\left(\mathrm{m}^{3} / \mathrm{s}\right)\end{array}$ & $\begin{array}{c}\text { Traditional- } \\
\text { GLD } \\
\left(\mathrm{m}^{3} / \mathrm{s}\right)\end{array}$ & $\begin{array}{c}\text { Traditional } \\
\left(\mathrm{m}^{3} / \mathrm{s}\right)\end{array}$ & $\begin{array}{c}\text { GLD } \\
\left(\mathrm{m}^{3} / \mathrm{s}\right)\end{array}$ \\
\hline 2011 & 0.86 & 0.84 & 9.69 & 9.48 & 0.21 & $0.01-9.69$ & $0.00-9.48$ \\
\hline 2012 & 2.52 & 2.50 & 56.81 & 56.28 & 0.53 & $0.08-56.81$ & $0.08-56.28$ \\
\hline 2013 & 2.54 & 2.52 & 25.45 & 25.39 & 0.07 & $0.04-25.45$ & $0.04-25.39$ \\
\hline 2014 & 4.53 & 4.52 & 66.49 & 65.98 & 0.51 & $0.35-66.49$ & $0.34-65.98$ \\
\hline 2015 & 4.21 & 4.19 & 61.63 & 61.41 & 0.22 & $0.14-61.63$ & $0.15-61.41$ \\
\hline 2016 & 2.01 & 1.99 & 18.00 & 17.75 & 0.25 & $0.05-18.00$ & $0.06-17.75$ \\
\hline 2017 & 2.45 & 2.44 & 33.13 & 32.84 & 0.29 & $0.21-33.13$ & $0.23-32.84$ \\
\hline 2018 & 1.84 & 1.82 & 50.97 & 50.40 & 0.57 & $0.06-50.97$ & $0.05-50.40$ \\
\hline 2019 & 2.43 & 2.41 & 30.05 & 29.59 & 0.46 & 0.06-30.05 & $0.05-29.59$ \\
\hline 2020 & 3.65 & 3.66 & 33.46 & 32.97 & 0.49 & $0.35-33.46$ & $0.37-32.97$ \\
\hline
\end{tabular}


Estimated average monthly flows and monthly flow ranges were also evaluated. There was no substantial difference $\left(0.00-0.03 \mathrm{~m}^{3} / \mathrm{s}\right)$ among traditional and GLD average monthly flows; however, average monthly flows varied from month to month with the highest average monthly flow in April (Traditional: $4.16 \mathrm{~m}^{3} / \mathrm{s}$; GLD: $4.15 \mathrm{~m}^{3} / \mathrm{s}$ ) and the lowest in August (Traditional: $1.18 \mathrm{~m}^{3} / \mathrm{s}$; GLD: $1.17 \mathrm{~m}^{3} / \mathrm{s}$ ) (Table 5.20$)$.

Predicted monthly flow ranges for traditional and GLD scenarios resulted in no substantial difference $\left(0.00-0.14 \mathrm{~m}^{3} / \mathrm{s}\right)$. However, monthly flow ranges varied when compared to other months as was the trend with the average monthly flows. Variances in monthly flow ranges were demonstrated by considerable differences in peak monthly flows over the twelve months. Peak monthly flow for August was $2.80 \mathrm{~m}^{3} / \mathrm{s}$ for the traditional reclamation and $2.79 \mathrm{~m}^{3} / \mathrm{s}$ for the GLD reclamation. However, peak monthly flow for November was $9.84 \mathrm{~m}^{3} / \mathrm{s}$ for the traditional reclamation and $9.81 \mathrm{~m}^{3} / \mathrm{s}$ for the GLD scenario (Table 5.20).

Table 5.20. Model predictions 1 (traditional) and 2 (GLD) average monthly flow and monthly flow range

\begin{tabular}{|c|c|c|c|c|}
\hline \multirow[b]{2}{*}{ Month } & \multicolumn{2}{|c|}{ Average Monthly Flow } & \multicolumn{2}{|c|}{ Monthly Flow Range } \\
\hline & $\begin{array}{l}\text { Traditional } \\
\qquad\left(\mathrm{m}^{3} / \mathrm{s}\right)\end{array}$ & $\begin{array}{c}\text { GLD } \\
\left(\mathrm{m}^{3} / \mathrm{s}\right)\end{array}$ & $\begin{array}{c}\text { Traditional } \\
\qquad\left(\mathrm{m}^{3} / \mathrm{s}\right)\end{array}$ & $\begin{array}{c}\text { GLD } \\
\left(\mathrm{m}^{3} / \mathrm{s}\right)\end{array}$ \\
\hline January & 3.51 & 3.50 & $1.36-6.97$ & $1.34-6.98$ \\
\hline February & 3.44 & 3.44 & $1.08-8.57$ & $1.11-8.53$ \\
\hline March & 2.71 & 2.71 & $0.15-4.20$ & $0.14-4.20$ \\
\hline April & 4.16 & 4.15 & $0.78-7.10$ & $0.74-7.09$ \\
\hline May & 3.48 & 3.48 & $0.75-9.19$ & $0.74-9.13$ \\
\hline June & 2.25 & 2.25 & $0.26-6.64$ & $0.27-6.63$ \\
\hline July & 2.28 & 2.25 & $0.60-6.48$ & $0.61-6.39$ \\
\hline August & 1.18 & 1.17 & $0.18-2.80$ & $0.18-2.79$ \\
\hline September & 1.75 & 1.73 & $0.12-6.71$ & $0.12-6.68$ \\
\hline October & 1.44 & 1.41 & $0.10-4.06$ & $0.10-4.00$ \\
\hline November & 2.68 & 2.65 & $0.16-9.84$ & $0.16-9.81$ \\
\hline December & 3.00 & 2.97 & $0.82-4.94$ & $0.78-4.80$ \\
\hline
\end{tabular}

\subsubsection{HSPF Prediction Model Results: Predictions 3, 4, and 5}

Prediction simulations 3 and 4 estimated the future hydrologic responses within the experimental watershed with conventional and GLD valley-fill reclamation. Model predictions 3 
and 4 resulted in no substantial difference in daily flow or volume (Fig. 5.14). Total flow, lowest $50 \%$ flow, highest $10 \%$ flow, mean storm volume, and mean storm peak flow decreased $(-0.34 \%$ to $-3.33 \%$ difference) for the geomorphic valley-fill reclamation compared to the traditional valley-fill reclamation (Table 5.21). Prediction simulations 3 and 4, resulted in larger differences $(-0.34 \%$ to $-3.33 \%$ difference) in flow and volume compared to prediction simulations 1 and 2 , percent differences $(-0.27 \%$ to $-1.1 \%$ difference; Table 5.17$)$. 


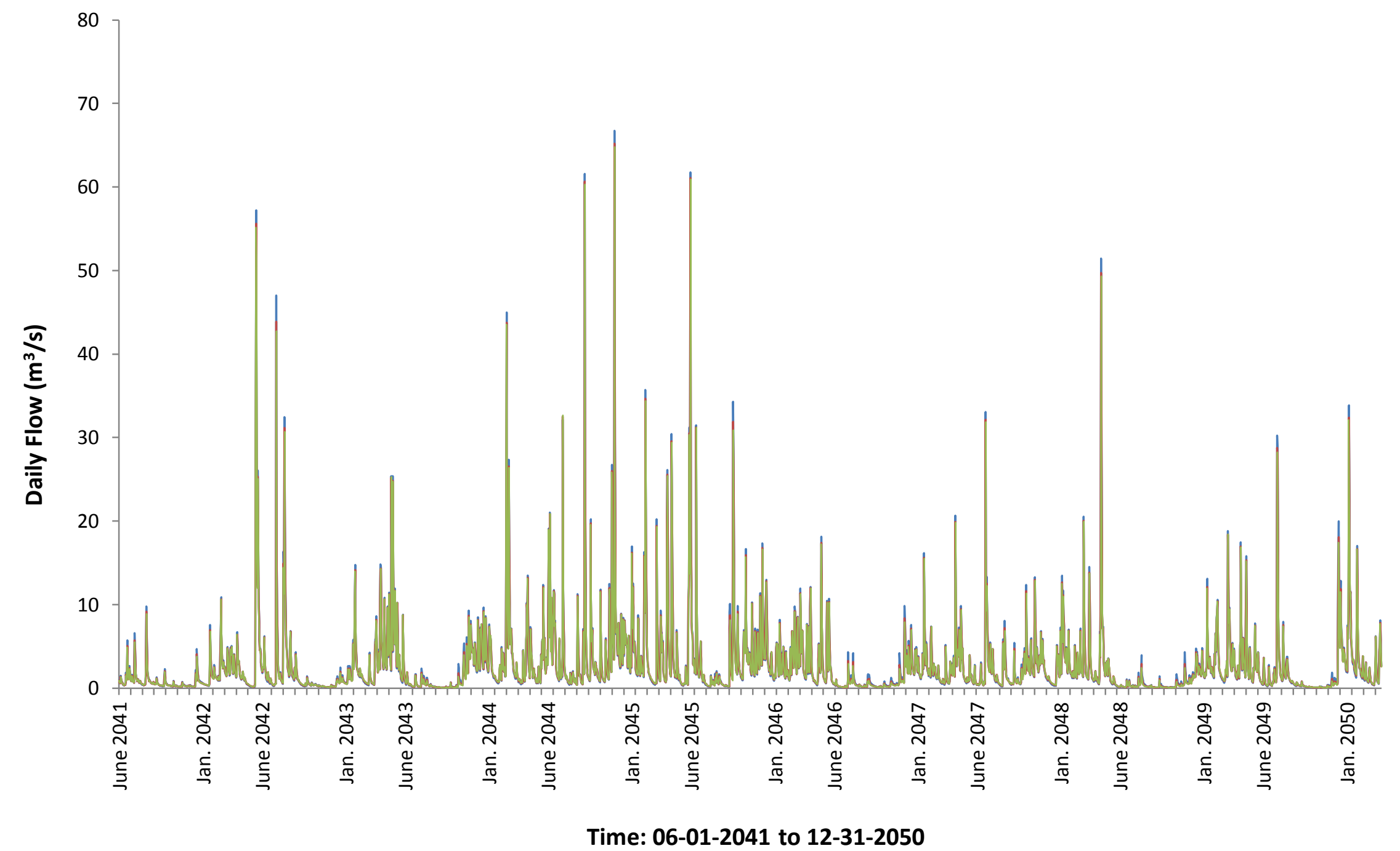

Figure 5.14. Model predictions 3, 4 and 5 daily flow comparison for 2041-2050 (traditional flow in blue, GLD flow in red, and NLD flow in green) 
Table 5.21. Model predictions 3 (traditional) and 4 (GLD) comparison

\begin{tabular}{cc}
\hline Prediction Criteria & D $\%$ \\
\hline Total Flow & -1.72 \\
Lowest 50\% Flow & -0.34 \\
Highest 10\% Flow & -2.64 \\
Mean Storm Volume & -2.11 \\
Mean Storm Peak Flow & -3.33 \\
\hline
\end{tabular}

Note: $\mathrm{D}_{\%}=\left(\mathrm{X}_{3, \mathrm{Trad}}-\mathrm{X}_{4, \mathrm{GLD}}\right) / \mathrm{X}_{4, \mathrm{GLD}}$; where

$\mathrm{X}_{3, \text { Trad }}=$ variable from simulation $3 ; \mathrm{X}_{4, \mathrm{GLD}}=$ variable

from simulation 4

Flood frequency analysis was performed using log-Pearson type III analysis for the observed model and model predictions 3 (traditional), 4 (GLD), and 5 (NLD) (Table 5.22; Figure 5.15). Observed annual peak stormflow values, using daily flow data, were used to determine 5-, 10-, 25-, 50-, 100-, and 200-year stormflows for the experimental watershed. Predicted annual peak stormflow values were used to predict the stormflows for model predictions 3,4 , and 5 . The predicted 100- and 200-yr stormsflows for the traditional, GLD, and NLD scenarios varied substantially. The 100 -yr GLD stormflow was $5,003 \mathrm{~m}^{3} / \mathrm{s}$ greater than the 100 -yr traditional stormflow and 4,969 $\mathrm{m}^{3} / \mathrm{s}$ less than the 100-yr NLD stormflow. The 100-yr GLD stormflow was $20,852 \mathrm{~m}^{3} / \mathrm{s}$ greater than the $100-\mathrm{yr}$ traditional stormflow and $20,993 \mathrm{~m}^{3} / \mathrm{s}$ less than the $100-\mathrm{yr}$ NLD stormflow (Table 5.22). Flood frequency trends were similar for the observed, future traditional, future GLD, and future NLD simulations (Figure 5.15). 
Table 5.22. Flood frequency calculations using log-Pearson type III analysis for observed and model predictions 3 (traditional), 4 (GLD), and 5 (no land disturbance)

\begin{tabular}{ccccccccc}
\hline & \multicolumn{2}{c}{ Observed } & \multicolumn{2}{c}{ Traditional } & \multicolumn{2}{c}{ GLD } & \multicolumn{2}{c}{ NLD } \\
\hline $\begin{array}{c}\text { Return } \\
\text { Period } \\
\text { (Years) }\end{array}$ & $\begin{array}{c}\text { Skew } \\
\text { Coefficient } \\
\mathbf{K}(\mathbf{0 . 1 5 0 6 )}\end{array}$ & $\begin{array}{c}\text { Discharge } \\
\left(\mathbf{m}^{\mathbf{3}} / \mathbf{s}\right)\end{array}$ & $\begin{array}{c}\text { Skew } \\
\text { Coefficient } \\
\text { K(-0.4315) }\end{array}$ & $\begin{array}{c}\text { Discharge } \\
\left(\mathbf{m}^{\mathbf{3}} / \mathbf{s}\right)\end{array}$ & $\begin{array}{c}\text { Skew } \\
\text { Coefficient } \\
\text { K(-0.4212) }\end{array}$ & $\begin{array}{c}\text { Discharge } \\
\left(\mathbf{m}^{\mathbf{3}} / \mathbf{s}\right)\end{array}$ & $\begin{array}{c}\text { Skew } \\
\text { Coefficient } \\
\text { K(-0.4115) }\end{array}$ & $\begin{array}{c}\text { Discharge } \\
\left(\mathbf{m}^{\mathbf{3}} / \mathbf{s}\right)\end{array}$ \\
\hline $\mathbf{2}$ & -0.025 & 0.0 & 0.071 & 0.1 & 0.070 & 0.1 & 0.068 & 0.1 \\
$\mathbf{5}$ & 0.833 & 19.6 & 0.855 & 23.1 & 0.855 & 23.0 & 0.855 & 23.0 \\
$\mathbf{1 0}$ & 1.297 & 547.6 & 1.226 & 330.7 & 1.228 & 334.4 & 1.229 & 337.9 \\
$\mathbf{2 5}$ & 1.802 & 20572.7 & 1.594 & 4622.8 & 1.598 & 4758.0 & 1.602 & 4889.0 \\
$\mathbf{5 0}$ & 2.133 & 222381.6 & 1.816 & 22804.3 & 1.822 & 23786.0 & 1.827 & 24749.0 \\
$\mathbf{1 0 0}$ & 2.436 & 1959191.3 & 2.006 & 88968.6 & 2.013 & 93972.0 & 2.020 & 98940.9 \\
$\mathbf{2 0 0}$ & 2.717 & 14686882.7 & 2.172 & 292947.1 & 2.181 & 313799.2 & 2.190 & 334791.8 \\
\hline
\end{tabular}

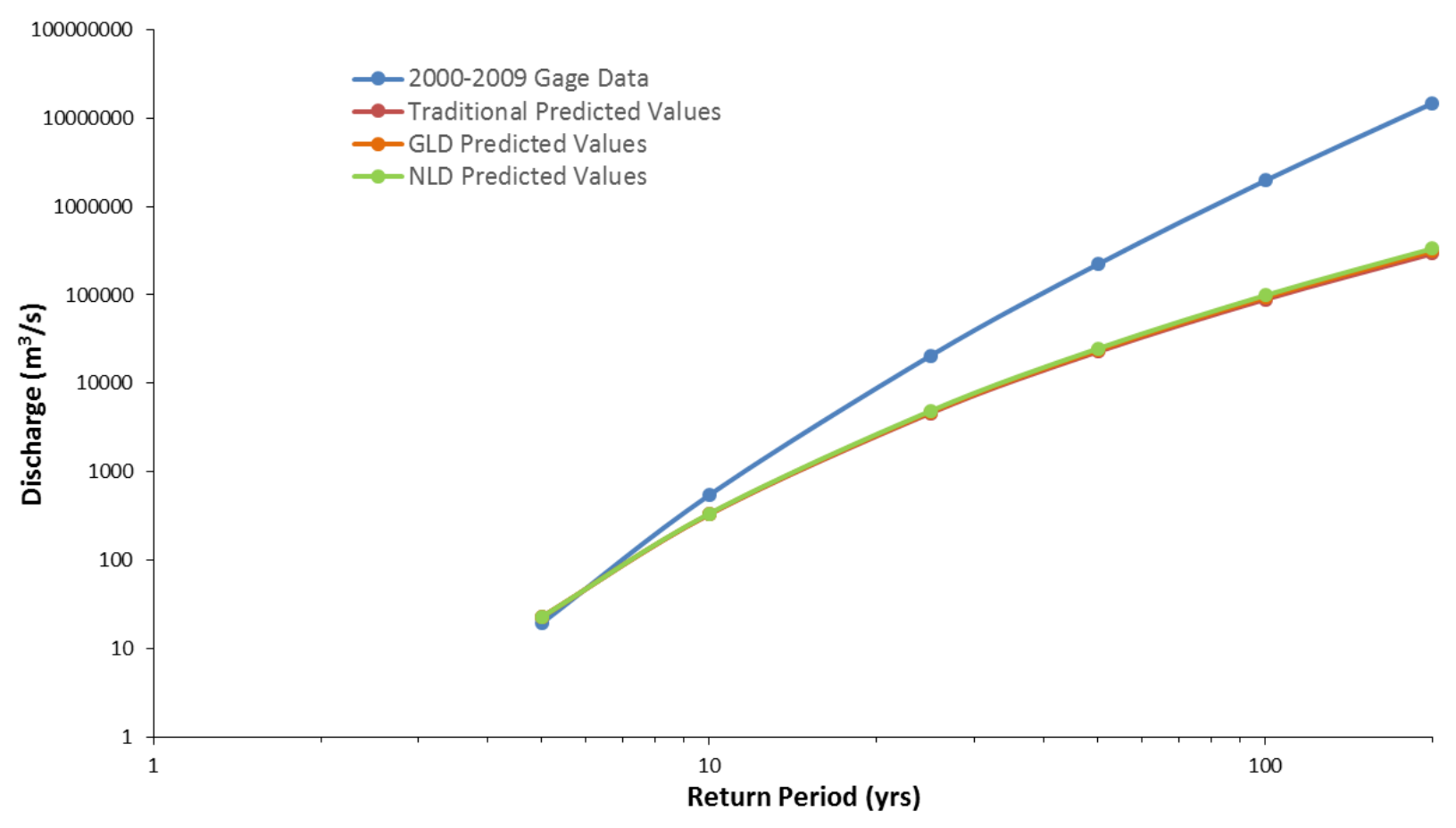

Figure 5.15. Flood frequency analysis for Clear Fork watershed using log-Pearson type III analysis using observed, future traditional predicted, future GLD predicted, and future NLD predicted annual peak stormflow values (log-log scale)

Prediction simulations 3 and 5 resulted in similar future hydrologic responses within the study watershed for conventional valley-fill reclamation compared to the no land disturbance 
(NLD) simulation (Fig. 5.14). The total flow, lowest 50\% flow, highest $10 \%$ flow, mean storm volume, and mean storm peak flow were higher for the watershed when conventional valley-fill reclamation was modeled as opposed to no land disturbance $(0.32 \%$ to $-4.36 \%$ difference; Table 5.23).

Table 5.23. Model predictions 3 (traditional) and 5 (no land disturbance) comparison

\begin{tabular}{cc}
\hline Prediction Criteria & $\mathbf{D}_{\%}$ \\
\hline Total Flow & 2.26 \\
Lowest 50\% Flow & 0.32 \\
Highest 10\% Flow & 3.53 \\
Mean Storm Volume & 2.88 \\
Mean Storm Peak Flow & 4.36 \\
\hline Note: D\%=(X & \\
$\mathrm{X}_{3, \text { Trad }}=$ variable $\left.\mathrm{X}_{5, \mathrm{NLD}}\right) / \mathrm{X}_{5, \mathrm{NLD}} ;$ where \\
from simulation 5
\end{tabular}

A comparison of prediction simulations 4 and 5 showed the future hydrologic impact was similar for the valley fills reclaimed using geomorphic reclamation methods compared to the no land disturbance simulation (Fig. 5.14). The total flow, highest 10\% flow, mean storm volume, and mean storm peak flow were higher for the watershed when geomorphic valley-fill reclamation was modeled as opposed to if no land disturbance had occurred in the watershed ( $0.51 \%$ to $0.89 \%$ difference; Table 5.24$)$. The lowest $50 \%$ flow was lower for the geomorphic valley-fill model compared to the no land disturbance model (-0.03\% difference; Table 5.24). 
Table 5.24. Model predictions 4 (GLD) and 5 (No Land Disturbance) comparison

\begin{tabular}{cc}
\hline Prediction Criteria & GLD vs NLD \\
\hline Total Flow & $0.51 \%$ \\
Lowest $50 \%$ Flow & $-0.03 \%$ \\
Highest 10\% Flow & $0.79 \%$ \\
Mean Storm Volume & $0.70 \%$ \\
Mean Storm Peak Flow & $0.89 \%$ \\
\hline Note: D $\%=\left(X_{4, G L D} \mathrm{X}_{5, \mathrm{NLD}}\right) / \mathrm{X}_{5, \mathrm{NLD}} ;$ where \\
$\mathrm{X}_{4, \mathrm{GLD}}=$ variable from simulation 4; $\mathrm{X}_{5, \mathrm{NLD}}=$ variable \\
from simulation 5
\end{tabular}

Average annual flows and annual peak stormflows were analyzed for prediction models 3 (traditional), 4 (GLD), and 5 (NLD) (Table 5.25). Average annual flows, based on daily flow values, were slightly increased (0.00-0.02 $\left.\mathrm{m}^{3} / \mathrm{s}\right)$ for the GLD prediction compared to the NLD prediction for all simulation years (2041-2050) except 2050. For 2050, the GLD average annual flow was $0.03 \mathrm{~m}^{3} / \mathrm{s}$ lower than the NLD condition. Average annual flows were slightly greater $\left(0.01-0.10 \mathrm{~m}^{3} / \mathrm{s}\right)$ for the traditional reclamation prediction compared to the NLD prediction for all model years (2041-2050) except 2050. The traditional average annual flow was $0.07 \mathrm{~m}^{3} / \mathrm{s}$ lower than the NLD model. Although the average annual flows resulted in no substantial difference when compared on a yearly basis $\left(0.01-0.10 \mathrm{~m}^{3} / \mathrm{s}\right)$, average annual flows varied substantially over the nine year model simulation (2041: $0.78-0.86 \mathrm{~m}^{3} / \mathrm{s} ; 2044: 4.5-4.52 \mathrm{~m}^{3} / \mathrm{s}$ ) (Table 5.25).

Annual peak stormflows for the traditional valley-fill reclamation simulation were greater $\left(0.86-2.12 \mathrm{~m}^{3} / \mathrm{s}\right)$ than the NLD model for all simulation years (2041-2050). Estimated GLD annual peak stormflows were $0.08-0.54 \mathrm{~m}^{3} / \mathrm{s}$ lower than the NLD simulation. Annual peak stormflows varied greatly (8.90-66.75 $\mathrm{m}^{3} / \mathrm{s}$ ) over the nine year model period (2041-2050) (Table $5.25)$. 
Table 5.25. Model predictions 3 (traditional), 4 (GLD), and 5 (no land disturbance) average annual flow and annual peak stormflow

\begin{tabular}{|c|c|c|c|c|c|c|}
\hline \multirow[b]{2}{*}{ Year } & \multicolumn{3}{|c|}{ Average Annual Flow } & \multicolumn{3}{|c|}{ Annual Peak Stormflow } \\
\hline & $\begin{array}{l}\text { Conventional } \\
\qquad\left(\mathrm{m}^{3} / \mathrm{s}\right)\end{array}$ & $\begin{array}{c}\text { GLD } \\
\left(\mathrm{m}^{3} / \mathrm{s}\right)\end{array}$ & $\begin{array}{c}\text { NLD } \\
\left(\mathrm{m}^{3} / \mathrm{s}\right)\end{array}$ & $\begin{array}{c}\text { Conventional } \\
\qquad\left(\mathrm{m}^{3} / \mathrm{s}\right)\end{array}$ & $\begin{array}{c}\text { GLD } \\
\left(\mathrm{m}^{3} / \mathrm{s}\right)\end{array}$ & $\begin{array}{l}\text { NLD } \\
\left(\mathrm{m}^{3} / \mathrm{s}\right)\end{array}$ \\
\hline 2041 & 0.86 & 0.80 & 0.78 & 9.78 & 9.14 & 8.90 \\
\hline 2042 & 2.52 & 2.47 & 2.46 & 57.23 & 55.62 & 55.16 \\
\hline 2043 & 2.54 & 2.48 & 2.47 & 25.37 & 24.81 & 24.73 \\
\hline 2044 & 4.52 & 4.51 & 4.51 & 66.75 & 65.21 & 64.82 \\
\hline 2045 & 4.21 & 4.17 & 4.15 & 61.77 & 61.10 & 60.91 \\
\hline 2046 & 2.02 & 1.94 & 1.92 & 18.14 & 17.39 & 17.22 \\
\hline 2047 & 2.44 & 2.41 & 2.40 & 33.06 & 32.15 & 31.85 \\
\hline 2048 & 1.85 & 1.78 & 1.76 & 51.45 & 49.73 & 49.33 \\
\hline 2049 & 2.43 & 2.38 & 2.36 & 30.24 & 28.78 & 28.24 \\
\hline 2050 & 3.63 & 3.67 & 3.70 & 33.85 & 32.41 & 32.10 \\
\hline
\end{tabular}

Modeled average monthly flows and monthly flow ranges for the nine year simulation (2041-2050) were also evaluated (Table 5.26). There was no substantial difference (0.00-0.15 $\mathrm{m}^{3} / \mathrm{s}$ ) among traditional, GLD, and NLD average monthly flows. For January, average monthly flows were lowest $\left(3.49 \mathrm{~m}^{3} / \mathrm{s}\right)$ for the GLD simulation and highest $\left(3.50 \mathrm{~m}^{3} / \mathrm{s}\right)$ for the NLD and traditional models. Average monthly flow for February was lowest $\left(3.43 \mathrm{~m}^{3} / \mathrm{s}\right)$ for the traditional reclamation scenario and highest $\left(3.45 \mathrm{~m}^{3} / \mathrm{s}\right)$ for the NLD simulation. For March, average monthly flow was lowest $\left(2.70 \mathrm{~m}^{3} / \mathrm{s}\right)$ for the traditional and GLD scenarios and highest $(2.71$ $\mathrm{m}^{3} / \mathrm{s}$ ) for the NLD model. Average monthly flows for April through December were highest for the traditional reclamation simulation and lowest for the NLD model. Over the nine year simulation period (2041-2050), average monthly flows varied on a monthly basis with the highest average monthly flow in April (4.14-4.16 $\left.\mathrm{m}^{3} / \mathrm{s}\right)$ and the lowest in August (1.11-1.18 $\mathrm{m}^{3} / \mathrm{s}$ ) (Table 5.26).

Predicted monthly flow ranges for traditional, GLD, and NLD scenarios resulted in no substantial difference $\left(0-0.15 \mathrm{~m}^{3} / \mathrm{s}\right)$. However, monthly flow ranges varied greatly over the nine year simulation as was the trend with the average monthly flows. Variances in monthly flow ranges were demonstrated by large differences in peak monthly flows over the twelve months. Peak monthly flow for August was $2.79 \mathrm{~m}^{3} / \mathrm{s}$ for the traditional and $2.76 \mathrm{~m}^{3} / \mathrm{s}$ for the GLD and 
the NLD. However, peak monthly flow for November was $9.86 \mathrm{~m}^{3} / \mathrm{s}$ for the traditional, 9.75 $\mathrm{m}^{3} / \mathrm{s}$ for the GLD, and $9.71 \mathrm{~m}^{3} / \mathrm{s}$ for the NLD (Table 5.26).

Table 5.26. Model predictions 3 (traditional), 4 (GLD), and 5 (no land disturbance) average monthly flow and monthly flow range

\begin{tabular}{ccccccc}
\hline & \multicolumn{3}{c}{ Average Monthly Flow } & \multicolumn{3}{c}{ Monthly Flow Range } \\
Month & $\begin{array}{c}\text { Traditional } \\
\left(\mathbf{m}^{3} / \mathbf{s}\right)\end{array}$ & $\begin{array}{c}\text { GLD } \\
\left(\mathbf{m}^{3} / \mathbf{s}\right)\end{array}$ & $\begin{array}{c}\text { NLD } \\
\left(\mathbf{m}^{3} / \mathbf{s}\right)\end{array}$ & $\begin{array}{c}\text { Traditional } \\
\left(\mathbf{m}^{3} / \mathbf{s}\right)\end{array}$ & $\begin{array}{c}\text { GLD } \\
\left(\mathbf{m}^{3} / \mathbf{s}\right)\end{array}$ & $\begin{array}{c}\text { NLD } \\
\left(\mathbf{m}^{3} / \mathbf{s}\right)\end{array}$ \\
\hline January & 3.50 & 3.49 & 3.50 & $1.38-6.94$ & $1.30-7.00$ & $1.28-7.03$ \\
February & 3.43 & 3.44 & 3.45 & $1.05-8.59$ & $1.14-8.49$ & $1.18-8.46$ \\
March & 2.70 & 2.70 & 2.71 & $0.15-4.20$ & $0.12-4.20$ & $0.12-4.21$ \\
April & 4.16 & 4.14 & 4.14 & $0.82-7.09$ & $0.68-7.08$ & $0.66-7.08$ \\
May & 3.47 & 3.46 & 3.46 & $0.75-9.23$ & $0.71-9.03$ & $0.71-8.96$ \\
June & 2.24 & 2.23 & 2.22 & $0.24-6.64$ & $0.28-6.60$ & $0.27-6.59$ \\
July & 2.29 & 2.18 & 2.14 & $0.58-6.53$ & $0.51-6.23$ & $0.44-6.11$ \\
August & 1.18 & 1.13 & 1.11 & $0.18-2.79$ & $0.17-2.76$ & $0.17-2.76$ \\
September & 1.76 & 1.68 & 1.64 & $0.10-6.73$ & $0.10-6.63$ & $0.09-6.60$ \\
October & 1.44 & 1.37 & 1.34 & $0.09-4.09$ & $0.09-3.92$ & $0.09-3.90$ \\
November & 2.70 & 2.59 & 2.56 & $0.16-9.86$ & $0.16-9.75$ & $0.16-9.71$ \\
December & 3.01 & 2.93 & 2.90 & $0.85-5.06$ & $0.72-4.65$ & $0.67-4.68$ \\
\hline
\end{tabular}

\subsection{Discussion}

Predictions 1 (current 2011-2020 conventional fill) and 2 (current 2011-2020 GLD fill) were modeled for comparison of the current hydrologic impact within the experimental watershed if geomorphic reclamation was implemented in place of traditional valley-fill reclamation. Stream flows and volumes were compared among the scenarios 1 and 2. Results indicated no substantial difference ( $<1.1 \%$ difference) in daily flow or volume (Table 5.17). Average annual flows were slightly reduced $\left(0.1-0.2 \mathrm{~m}^{3} / \mathrm{s}\right)$ for the GLD prediction compared to the conventional prediction. Annual peak stormflows were $0.07-0.57 \mathrm{~m}^{3} / \mathrm{s}$ lower for the GLD simulation compared to the traditional simulation. The minimal difference between the flows modeled for simulations 1 and 2 could be attributed to the focus on valley-fill reclamation areas only ( $11 \mathrm{~km}^{2} ; 6.6 \%$ of experimental watershed), as opposed to all mining/disturbed areas within the watershed $\left(52 \mathrm{~km}^{2} ; 31 \%\right.$ of the experimental watershed). During model predictions, only 
valley-fill areas were altered from one land use condition to another (Table 5.8; Table 5.9). Mined land (barren land) was assumed to become reclaimed land (grassland) within the watershed over time. The small amount of land use change $(6.6 \%)$ within the model indicates the minimal change in modeled flows for simulations 1 and 2.

Over the nine year model, average annual flows (2011: 0.84-0.86 m³/s; 2014: 4.52-4.53 $\mathrm{m}^{3} / \mathrm{s}$ ) and annual peak stormflows (2011: 9.48-9.69 $\mathrm{m}^{3} / \mathrm{s} ; 2014: 65.98-66.49 \mathrm{~m}^{3} / \mathrm{s}$ ) varied substantially for simulations 1 and 2 (Table 5.17). The large differences in flows over the model study period could be attributed to the substantial average annual precipitation variances over the simulation period. Average precipitation for the Dry Creek watershed in 2002 was $31 \%$ less than the historical average precipitation; however, in 2004, the average precipitation was $37 \%$ higher than the historical average precipitation (Figure 5.3; Figure 5.4).

There was no substantial difference $\left(0.00-0.03 \mathrm{~m}^{3} / \mathrm{s}\right)$ in monthly flows among simulation 1 and 2. However, average monthly flows varied from month to month with the highest average monthly flow in April (Traditional: $4.16 \mathrm{~m}^{3} / \mathrm{s}$; GLD: $4.15 \mathrm{~m}^{3} / \mathrm{s}$ ) and the lowest in August (Traditional: $1.18 \mathrm{~m}^{3} / \mathrm{s}$; GLD: $1.17 \mathrm{~m}^{3} / \mathrm{s}$ ). Differences in monthly flows could be attributed to seasonal precipitation variability. Figure 5.3 illustrated the variableness of hourly precipitation at the Dry Creek weather station. The highest average monthly flows could be attributed to snow melt and increased precipitation that could be expected in the experimental watershed in the Spring season (Figure 5.3). The lowest average monthly flows could be attributed decreased precipitation in the watershed as shown in Figure 5.3.

Predictions 3 (future 2041-2050 conventional fill), 4 (future 2041-2050 GLD fill), and 5 (future 2041-2050 no land disturbance) were modeled for comparison of the future hydrologic impact within the experimental watershed if geomorphic reclamation was implemented in place of traditional valley-fill reclamation and if no land disturbance had occurred. No substantial difference occurred in future stream flows or volumes for the watershed when GLD and conventional valley-fill reclamation were compared to the NLD (conventional: $0.32 \%$ to $-4.36 \%$ difference, Table 5.23; GLD: $0.51 \%$ to $0.89 \%$ difference, Table 5.24). Predicted stream flows and volumes decreased (-0.34\% to $-3.33 \%$ difference) for the geomorphic valley-fill reclamation compared to the traditional valley-fill reclamation (Table 5.21). Prediction simulations 3 and 4, resulted in larger differences (- $0.34 \%$ to $-3.33 \%$ difference) in flow and volume compared to prediction simulations 1 and 2 (-0.27\% to $-1.1 \%$ difference; Table 5.17). The minimal 
differences between future flows and volumes when traditional and GLD valley-fill reclamation techniques were compared. This could be attributed to the emphasis on valley-fill areas $\left(33 \mathrm{~km}^{2}\right.$; $19.8 \%$ of experimental watershed), as opposed to the total disturbed areas within the watershed ( $76 \mathrm{~km}^{2} ; 46 \%$ of the experimental watershed). Mining land use was assumed to become reclaimed land and diminish over time as reserves within the watershed depleted. It was also assumed that valley fills from past mining activity would require extended periods of time to be reclaimed. However, future mining and reclamation trends are difficult to predict and further HSPF modeling might be necessary to determine if mining practices within the watershed were to greatly increase in the future. Minimal differences in future hydrologic responses could also be attributed to the long-term hydrologic models (prediction simulations 3, 4, and 5) not incorporating any alterations of the landscape due to long-term erosional changes.

Average annual flows were slightly increased for prediction $3\left(0.01-0.10 \mathrm{~m}^{3} / \mathrm{s}\right.$ greater) and prediction $4\left(0-0.02 \mathrm{~m}^{3} / \mathrm{s}\right.$ larger) compared to prediction 5 for all simulation years (20412050) except 2050. For 2050, the traditional average annual flow was $0.07 \mathrm{~m}^{3} / \mathrm{s}$ lower than the NLD simulation and the GLD average annual flow was $0.03 \mathrm{~m}^{3} / \mathrm{s}$ lower than the NLD condition. Although the average annual flows resulted in no substantial difference when compared on a yearly basis $\left(0-0.10 \mathrm{~m}^{3} / \mathrm{s}\right)$, average annual flows varied substantially over the nine year model simulation (2041: 0.78-0.86 m³ $/ \mathrm{s} ; 2044: 4.5-4.52 \mathrm{~m}^{3} / \mathrm{s}$ ) (Table 5.25).

Annual peak stormflows for the traditional valley-fill reclamation simulation were 0.86 $2.12 \mathrm{~m}^{3} / \mathrm{s}$ greater than the NLD annual peak stormflows and GLD annual peak stormflows were $0.08-0.54 \mathrm{~m}^{3} / \mathrm{s}$ lower than the NLD simulation. Similar to the modeled current annual peak stormflows, the modeled future annual peak stormflows varied greatly $\left(8.90-66.75 \mathrm{~m}^{3} / \mathrm{s}\right)$ over the nine year model period (2041-2050; Table 5.25). The substantial differences in average annual precipitation over the simulation period could be the cause of the large differences in annual peak stormflows (Figure 5.4).

No substantial difference $\left(0.00-0.15 \mathrm{~m}^{3} / \mathrm{s}\right)$ resulted among the average monthly flows of simulations 3, 4, and 5. However, monthly flows varied greatly from month to month and could be due to seasonal precipitation and temperature variability. Over the nine year simulation period (2041-2050), average monthly flows varied on a monthly basis with the highest average monthly flow in April (4.14-4.16 $\mathrm{m}^{3} / \mathrm{s}$ ) and the lowest in August (1.11-1.18 $\mathrm{m}^{3} / \mathrm{s}$ ) (Table 5.26). Figure 5.3 illustrated the variableness of hourly precipitation at the closest weather station. 
Predicted monthly flow ranges for simulations 3, 4, and 5 resulted in no substantial difference $\left(0-0.15 \mathrm{~m}^{3} / \mathrm{s}\right)$. However, monthly flow ranges varied greatly over the nine year simulation as was the trend with the average monthly flows. Variances in monthly flow ranges were demonstrated by large differences in peak monthly flows over the twelve months. Peak monthly flow for August was $2.79 \mathrm{~m}^{3} / \mathrm{s}$ for the traditional and $2.76 \mathrm{~m}^{3} / \mathrm{s}$ for the GLD and the NLD. However, peak monthly flow for November was $9.86 \mathrm{~m}^{3} / \mathrm{s}$ for the traditional, $9.75 \mathrm{~m}^{3} / \mathrm{s}$ for the GLD, and $9.71 \mathrm{~m}^{3} / \mathrm{s}$ for the NLD (Table 5.26).

Flood frequency analysis resulted in no substantial difference $\left(0-18 \mathrm{~m}^{3} / \mathrm{s}\right)$ among the predicted 2-, 5-, 10-, 25-, and 50-yr stormflows for simulations 1 and 2. However, the current GLD 100- and 200-yr storms flows were greater than the traditional stormflows (100-yr: 90.1 $\mathrm{m}^{3} / \mathrm{s}$ difference; 200-yr: $368.1 \mathrm{~m}^{3} / \mathrm{s}$ difference) (Table 5.18). No substantial difference resulted among the 2-, 5-, 10-, 25-, 50-, 100-, and 200-year stormflows for simulations 3, 4, and 5. However, the predicted 100- and 200-yr stormflows for the future traditional, GLD, and NLD scenarios varied greatly. The 100-yr GLD stormflow was 5,003 m³/s greater than the $100-\mathrm{yr}$ traditional stormflow and 4,969 $\mathrm{m}^{3} / \mathrm{s}$ less than the 100-yr NLD stormflow. The 100-yr GLD stormflow was $20,852 \mathrm{~m}^{3} / \mathrm{s}$ greater than the 100 -yr traditional stormflow and $20,993 \mathrm{~m}^{3} / \mathrm{s}$ less than the 100-yr NLD stormflow (Table 5.22). The change in stormflows between the simulations could be attributed to the land use/land cover change within the watershed for each of the reclamation practices.

Hydrologic response modeling through HSPF was used to identify differences and trends in flows and volumes that could be used for mitigation plans in a disturbed experimental watershed. One school and two Army Corp. of Engineers' dams are located within the impacted watershed and would have the potential to be damaged during flooding, resulting in possible property damage, economical loss, and loss of life. Predicted hydrologic response impacts would provide knowledge on flood mitigation in the study watershed and other watersheds impacted by surface mining and reclamation. These results and trends are expected to be similar across watersheds in Central Appalachia and the hydrologic prediction technique used has the potential to be applied to many reclamation simulations with differing land uses and valley-fill areas. 


\section{Conclusions}

\subsection{Valley-Fill Designs using Geomorphic Landform Principles}

Alternative and retrofit valley-fill designs were created for a valley-fill reclamation site in southern West Virginia using the design tool Carlson ${ }^{\circledR}$ Natural Regrade ${ }^{\circledR}$ with GeoFluv ${ }^{\mathrm{TM}}$ and geomorphic landform principles. The alternative geomorphic reclamation design was created using regional field data to more accurately mimic the undisturbed topography. The GLD topography had a permit area of $0.98 \mathrm{~km}^{2}$ and was comprised of ridges, valleys, and channels, resembling the pre-mined topography. Overall resulting drainage density of the site was $5.6 \mathrm{~km}^{-}$

${ }^{1}$, within the target range of $5.3 \pm 20 \% \mathrm{~km}^{-1}$, suggesting site hydrologic balance. Additionally, the drainage density of each channel was within the targeted range as to create a balanced design. Created channels (13 stream channels; 5,466 m total combined length; 131-1,440 m length range; type A and type C (Rosgen, 1994)) mimicked the pre-disturbed dendritic drainage pattern of the site. Main valley slope was $12.7 \%$ and the elevation ranged from $354 \mathrm{~m}$ to $608 \mathrm{~m}$. The regional data GLD implemented stream channel mitigation on site and allowed the mitigation credits to remain on the disturbed area.

The retrofit reclamation design applied geomorphic landform principles to the top of a valley fill constructed using conventional methods. The conventional valley fill consisted of a slightly sloping (1-2\%) crest with surrounding SWROA drainage ditches. The geomorphic retrofit design resulted in 8,345 $\mathrm{m}$ of stream length (124-927 $\mathrm{m}$ length range) on the fill crest surface. Streams for each section were characterized by a main channel and tributary channels forming a dendritic drainage pattern and helped control drainage on the property through the channelization of runoff. All of the channels were checked to have a drainage density within the targeted default range of 6.0-9.0 $\mathrm{km}^{-1}$ and the retrofit design had an overall drainage density range of 7.1-8.9 $\mathrm{km}^{-1}$. The design corresponded with government regulations including no flow over the valley-fill face. The retrofit design has the ability to be applied to previously constructed, bond failing, and un-reclaimed valley fills and allows stream channel mitigation on site.

Two additional enhanced geomorphic reclamation design were created by implementing surface runoff retention structures on the regional data GLD. The GLD design surface was used as the base for the surface water retention designs, which included a design with three bench 
ponds and a design with three valley ponds. The bench pond design included retention structures that mimicked riparian wetlands and were located beside the GLD channels. The implementation of bench ponds on geomorphic valley fills could result in benefits of riparian wetlands, including diverse wildlife and vegetative habitat. Three valley ponds were designed on the regional data GLD to potentially provide perennial streamflow on the site surface. The structures were designed to retain surface water runoff traveling downstream in the channelized flow paths, creating ponds. The geomorphic design with stream channels and valley ponds could provide hydrologic and ecological benefits, diverse habitat for wildlife and vegetation, and potential perennial streamflow downstream of the ponds if sized correctly.

\subsection{Sediment Load using Revised Universal Soil Loss Equation (RUSLE)}

The Revised Universal Soil Loss Equation (RUSLE) was utilized in a distributed GIS framework to predict erosion rates and spatial distributions for the GLD and conventional valleyfill designs during multiple stages in the mining and reclamation process (post-mining prevegetation and post-reclamation long term). The rainfall-runoff factor, soil erodibility factor, slope length and steepness factors, cover and management factor, and supporting practices factor were created as raster layers in a GIS environment and multiplied together using the RUSLE formula to estimate the average annual soil loss rates and spatial distribution patterns for the study area. The results for the five design scenarios were determined and a comparison of the results was performed to determine areas of high erosion risk. The pre-vegetation conditions resulted in high soil loss spatial means for both the conventional and GLD reclamation scenarios (conventional: $928.9 \mathrm{t} \mathrm{ha}^{-1} \mathrm{yr}^{-1}$; GLD: $986.4 \mathrm{t} \mathrm{ha}^{-1} \mathrm{yr}^{-1}$ ). Spatial means of the predicted erosion rates resulted in substantial difference among the undisturbed condition and the pre-vegetation conditions for both the conventional and GLD reclamation scenarios. The conventional fill prevegetation scenario resulted in an erosion rate spatial mean 3.5 times higher than the undisturbed condition. The GLD pre-vegetation scenario resulted in an erosion rate spatial mean 5.8 times higher than the undisturbed condition.

The long-term soil loss spatial means were substantially lower than the pre-vegetation conditions due to established vegetation that protected the soil from surface erosion forces (conventional: $93.2 \mathrm{t} \mathrm{ha}^{-1} \mathrm{yr}^{-1}$; GLD: $96.1 \mathrm{t} \mathrm{ha}^{-1} \mathrm{yr}^{-1}$ ). There was no considerable difference among the spatial means of the predicted erosion rates of the undisturbed, pre-mining condition 
(35.4 tha $\left.\mathrm{year}^{-1}\right)$ and the conventional $\left(35.6 \mathrm{t} \mathrm{ha}^{-1}\right.$ year $\left.^{-1}\right)$ and GLD $\left(41.8 \mathrm{t} \mathrm{ha}^{-1}\right.$ year $\left.^{-1}\right)$ postreclamation, long term conditions (Table 4.4).

Low soil loss rates for both the undisturbed condition and GLD conditions (undisturbed: $<20 \mathrm{tha}^{-1} \mathrm{yr}^{-1}$; GLD: $<30 \mathrm{t} \mathrm{ha}^{-1} \mathrm{yr}^{-1}$ ) occurred along the ridgelines. High erosion rates (undisturbed: $>50 \mathrm{t} \mathrm{ha}^{-1} \mathrm{yr}^{-1}$; GLD pre-vegetation: >100 $\mathrm{tha}^{-1} \mathrm{yr}^{-1}$; GLD long term: >150 $\mathrm{t} \mathrm{ha}^{-1}$ $\mathrm{yr}^{-1}$ ) occurred along the valleys, stream channels, and steep slopes (slope $>50 \%$ ). The soil loss

patterns of the conventional reclamation designs showed increased erosion risk $\left(>100 \mathrm{tha}^{-1} \mathrm{yr}^{-1}\right)$ for the valley-fill face and SWROA ditches. Future maintenance could be targeted to high erosion areas and design methods could be improved by decreasing the high erosion risk areas in future designs.

\subsection{Hydrologic Response of Valley-Fill Designs at the Landscape Scale}

An HSPF model was calibrated for a watershed in southern West Virginia that has been disturbed by surface mining and valley-fill activities. The HSPF model was used to predict the current and future hydrologic responses of the watershed if the valley fill was reclaimed using traditional or geomorphic landform techniques or if no land disturbance had occurred. Five prediction models were performed to estimate the current (2011-2020) and future (2041-2050) hydrologic response of the watershed during different stages in the mining and reclamation process and included: 1) current hydrologic response given conventionally reclaimed valley fills; 2) current hydrologic response given GLD valley fills; 3) future hydrologic response given conventionally reclaimed valley fills; 4) future hydrologic response given GLD valley fills; and 5) future hydrologic response given no land disturbance occurred in the watershed. Predictions were completed by changing the HSPF model land use parameters to mimic the proposed land use conditions for each of the scenarios. The estimated hydrologic responses were compared to assist in the determination of the hydrologic impacts and could be used for flood mitigation plans within the disturbed experimental watershed.

Stream flows were compared among the scenarios 1 and 2. Results indicated no substantial difference in daily flow $\left(<1.1 \%\right.$ difference) or monthly flow $\left(0.00-0.03 \mathrm{~m}^{3} / \mathrm{s}\right.$ difference). Average annual flows were slightly reduced (0.1-0.2 $\left.\mathrm{m}^{3} / \mathrm{s}\right)$ for the GLD prediction compared to the conventional prediction. Annual peak stormflows were $0.07-0.57 \mathrm{~m}^{3} / \mathrm{s}$ lower for the GLD simulation compared to the traditional simulation. Over the nine year model, average 
annual flows (2011: 0.84-0.86 m³ $/ \mathrm{s} ; 2014: 4.52-4.53 \mathrm{~m}^{3} / \mathrm{s}$ ) and annual peak stormflows (2011: 9.48-9.69 $\mathrm{m}^{3} / \mathrm{s} ; 2014: 65.98-66.49 \mathrm{~m}^{3} / \mathrm{s}$ ) varied substantially for simulations 1 and 2 .

Stream flows were compared among scenarios 3,4 , and 5 . No substantial difference occurred in future stream flows or volumes for the watershed when GLD and conventional valley-fill reclamation were compared to the NLD (conventional: $0.32 \%$ to $-4.36 \%$ difference; GLD: $0.51 \%$ to $0.89 \%$ difference). Predicted stream flows and volumes decreased $(-0.34 \%$ to $3.33 \%$ difference) for the geomorphic valley-fill reclamation compared to the traditional valleyfill reclamation. Average annual flows were slightly increased for prediction $3\left(0.01-0.10 \mathrm{~m}^{3} / \mathrm{s}\right.$ greater) and prediction $4\left(0-0.02 \mathrm{~m}^{3} / \mathrm{s}\right.$ larger) compared to prediction 5 for all simulation years (2041-2050) except 2050. For 2050, the traditional average annual flow was $0.07 \mathrm{~m}^{3} / \mathrm{s}$ lower than the NLD simulation and the GLD average annual flow was $0.03 \mathrm{~m}^{3} / \mathrm{s}$ lower than the NLD condition. Annual peak stormflows for the traditional valley-fill reclamation simulation were $0.86-2.12 \mathrm{~m}^{3} / \mathrm{s}$ greater than the NLD annual peak stormflows and GLD annual peak stormflows were $0.08-0.54 \mathrm{~m}^{3} / \mathrm{s}$ lower than the NLD simulation. No substantial difference $\left(0.00-0.15 \mathrm{~m}^{3} / \mathrm{s}\right)$ resulted among the average monthly flows of simulations 3, 4, and 5 . 


\section{Implications of the Study}

\section{Proposed Contributions to the Body of Knowledge}

The overall contribution of this research to the body of knowledge is providing hydrologic and modeling analysis of the implementation of geomorphic landform valley-fill reclamation designs in Central Appalachia.

1. This research illustrated enhanced valley-fill reclamation designs can be created using geomorphic landform principles for both pre-existing valley fills and future valley fills in Central Appalachia. The designs implemented stream mitigation on site through the creation of stream channels on the fill. Design features included slope profile complexity, enhanced water retention structures, and wildlife and vegetative habitat.

2. This research predicted the impact of different valley-fill reclamation techniques on soil loss rates and spatial distributions in a watershed in southern West Virginia. Model predictions illustrated the areas of high erosion risk and soil loss rates for the designed conventional valley fill and geomorphic valley fill at multiple stages in the mining and reclamation process. The soil loss prediction technique and results have the potential to be applied to many reclamation simulations with differing soil characteristics and land uses.

3. This research predicted current and future changes in hydrologic responses of different valley-fill reclamation techniques during multiple stages in the mining and reclamation process to provide understanding of the hydrologic processes altered by mining and reclamation at the landscape scale. Changes in stream flows and volumes were predicted by hydrologic modeling of a watershed in southern West Virginia disturbed by surface mining and valley-fill activities. The results could be projected throughout disturbed watersheds in Central Appalachia to improve flood mitigation, reclamation methods, and conservation practices. 


\section{Limitations of Study and Future Research Recommendations}

\subsection{Valley-Fill Designs using Geomorphic Landform Principles}

The geomorphic landform design research was limited by not having a reference geomorphic valley fill in Central Appalachia for comparison of research results. Future research should include a small scale construction project of a region specific geomorphic landform design in Central Appalachia to demonstrate success of application and prior research findings. Future research should also include long-term monitoring of hydrology, erosion, groundwater movement, stability, cost, and maintenance of the constructed site. Extensive research should also be completed on the stream channels constructed on the GLD site including long-term monitoring of materials, erosion, maintenance, cost, aquatic species, and aquatic habitat.

\subsection{Sediment Load using Revised Universal Soil Loss Equation (RUSLE)}

The RUSLE modeling was limited by the lack of documented soil erosion rates and spatial distributions for mined sites in southern West Virginia for result comparison. The RUSLE model has a number of subjective judgements that must be made when assigning parameters (Evans and Loch, 1996). Therefore, great care must be taken when estimating input parameters and proper documentation must be made to document all parameter justifications. This subjectivity can lead to skewed results or inaccurate conclusions. Soil erosion data collected from additional study sites, including a constructed GLD in Central Appalachia, would be beneficial for result validation and improved knowledge of erosion rates and distribution.

\subsection{Hydrologic Response of Valley-Fill Designs at the Landscape Scale}

The HSPF modeling was limited by the lack of meteorological data from the study watershed and surrounding area. The meteorological data used may not have accurately reflected the weather pattern of the study area due to the watershed being located approximately $21 \mathrm{~km}$ away from the closest meteorological station. The modeled predictions could be further improved if the meteorological data inputs more accurately represented the meteorological events within the experimental watershed. Future research should include HSPF modeling of a watershed, near the watershed modeled in this study, to verify the hydrologic impact predictions and expand prediction data for disturbed watersheds in southern West Virginia. 
Another limitation of the HSPF modeling was the focus of this study on future valley-fill construction with limited future mining. Future HSPF modeling should include future valley-fill construction as well as increased mining/land use change to determine changes in hydrologic response at the landscape scale for these conditions. Increased mining and valley-fill activity in the watershed could lead to substantial hydrologic impacts. 


\section{References}

Arnoldus, H., 1980. An approximation of the rainfall factor in the Universal Soil Loss Equation. In: De Boodt, M., and D. Gabriels (eds), Assessmetn of erosion Chichester. Wiley, New York.

Atkins, J.T., J.B. Wiley, and K.S. Paybins, 2005. Calibration parameters used to simulate streamflow from application of the Hydrologic Simulation Program-FORTRAN model (HSPF) to mountainous basins containing coal mines in West Virginia. USGS Scientific Investigations Report, 2005-5099.

Balcombe, C. K., J. T. Anderson, R. H. Fortney, J. S. Rentch, W. N. Grafton, and W. S. Kordek, 2005. A comparison of wetland plant communities in mitigation and reference wetlands in the Mid-Appalachians. Wetlands 25:130-142.

Berger, C., M. Schulze, D. Rieke-Zapp, and F. Schlunegger, 2010. Rill development and soil erosion: a laboratory study of slope and rainfall. Earth Surface Process and Landform, 35, 1456-1467.

Bernhardt, E.S., and M.A. Palmer, 2011. The environmental costs of mountaintop mining valley fill operations for aquatic ecosystems of the Central Appalachians. Annals of the New York Academy of Sciences, 1223:39-57.

Bonham, J. and K. Stephenson, 2004. A cost analysis of stream compensatory mitigation project in the Southern Appalachian Region. American Society of Agricultural Engineers, SelfSustaining Solutions for Streams, Watersheds, and Wetlands Conference, St. Paul, MN, Sept. 12-15, 2004.

Bonta, J.V., C.R. Amerman, T.J. Harlukowicz, and W.A. Dick, 1997. Impact of coal surface mining on three Ohio watersheds-Surface water hydrology. Journal of the American Water Resources Association, 33(4), 907-917.

Brun, S.E., and L.E. Band, 2000. Simulating runoff behavior in an urbanizing watershed. Computers, Environment, and Urban Systems, 24, 5-22.

Bu, Z.H., W.L. Tang, L.Z. Yang, C.F. Xi, F.X. Liu, J.Y. Wu, and H.N. Tang, 2003. The progress of quantitative remote sensing method for annual soil losses and its application in Taihu-Lake Watersheds. Acta Pedol Sin (in Chinese), 40(1):1-9.

Buckley, C., L.C. Hopkinson, J.D. Quaranta, and P. Ziemkiewicz, 2013. Investigating regional design parameters in the design of West Virginia valley fills to support application of 
geomorphic landform design principles. Environmental Considerations in Energy Production, Society for Mining, Metalurgy, and Exploration, Charleston, WV, April 1418.

Bugosh, N. 2004. Computerizing the fluvial geomorphic approach to land reclamation, National Meeting of the American Society of Mining and Reclamation and The 25th West Virginia Surface Mine Drainage Task Force, April 18-24, 240-258.

Bugosh N., 2009. A summary of some land surface and water quality monitoring results for constructed GeoFluv landforms: Revitalizing the Environment: Proven Solutions and Innovative Approaches. National Meeting of the American Society of Mining and Reclamation, Billings, MT, May 30-June 5, 2009.

Carroll, C., I Merton, and P. Burger, 2000. Impact of vegetative cover and slope on runoff, erosion, and water quality for field plots on a range of soil and spoil materials on central Queensland coal mines. Journal of Soil Research, 38, 313-327.

CETCO, 2014. Geosynthetic clay liners. Retrieved from: http://lining.cetco.com/Left-SideNavigation/GEOSYNTHETIC-CLAY-LINERS

Chen, T., R. Niu, P. Li, L. Zhang, and B. Du, 2011. Regional soil erosion risk mapping using RUSLE, GIS, and remote sensing: a case study in Miyun Watershed, North China. Environmental Earth Sciences, 63, 533-541.

Curtis, W.R., and M.J. Superfesky, 1977. Erosion of surface mine spoils. Proc. Of $32^{\text {nd }}$ Annual Meeting of the Soil Conservation Society of America, 154-158.

Daniels, W.L., K.C. Haering, and J.M. Galbraith, 2004. Mine soil morphology and properties in pre- and post-SMCRA coal mined landscapes in southwestern Virginia. Proc., National Meeting of America Society of Mining and Reclamation, University of Kentucky, Lexington, KY, 421-449.

Dash, S. K., N. R. Krishnaswamy, and K. Rajagopal, 2001. Bearing capacity of strip footings supported on geocell-reinforced sand. Geotext Geomembranes 19; 235-256.

DePriest, N.C. L.C. Hopkinson, J.D. Quaranta, P.R. Michael, and P.F. Ziemkiewicz, 2015. Geomorphic landform design alternatives for an existing valley fill in central Appalachia, USA: Quantifying key issues, Ecological Engineering, http://dx.doi.org/10.1016/j.ecoleng.2015.04.007 
Demirci, A., and A. Karaburun, 2012: Estimation of soil erosion using RUSLE in a GIS framework: a case study in the Buyukcekmece Lake watershed, northwest Turkey. Environ Earth Sci, 66, 903-913.

Donigian, A.S., Baker, D.A. Haith, and M.F. Waler, 1983. HSPF parameter adjust ments to evaluate the effects of agricultural best management practices. EPA contract No. 68-032895, U.S. EPA Environmental Research Laboratory, Athens, Georgia.

Donigian, A.S., and H.H. Davis, 1978. User's manual for Agricultural Runoff Management (ARM) model. U.S. Environmental Protection Agency, EPA-600/3-78-080.

Donigian, A.S., and W.C. Huber, 1991. Modeling of nonpoint source water quality in urban and non-urban areas. U.S. Environmental Protection Agency, Environmental Research Laboratory, EPA/600/3-91-039.

Duda, P.B., P.R. Hummel, A.S. Donigian Jr., and J.C. Imhoff, 2012. BASINS/HSPF: Model use, calibration, and validation. American Society of Agricultural and Biological Engineers, 55(4), 1523-1547.

Eckels, R., and N. Bugosh, 2010. Natural Approach to Mined Land Rehabilitation. International Federation de Geometres (FIG) Congress Sydney, Australia, April 11-16, 2010.

Eshleman, K.N., 2004. Hydrological consequences of land use change: A review of the state-ofscience. In R. Defries, G. Asner, and S Houghton (Ed.) Ecosystems and Land Use Change, Geophys. Monogr. Ser (vol. 153, pp. 13-29). Washington, D.C.: American Geophysical Union (AGU).

Espigares, T., M. Moreno de las Heras, and J.M. Nicolau, 2011. Performance of vegetation in reclaimed slopes affected by soil erosion. Restoration Ecology, 19, 35-44.

Evans, K.G., and R.J. Loch, 1996. Using the RUSLE to identify factors controlling erosion rates of mine soils. Land Degradation \& Development, 7, 267-277.

FACES: Federation for American Coal, Energy, and Security, 2015. Mining Permits: Surface mining permitting delays put jobs and energy production at risk. Retrieved from http://www.facesofcoal.org/index.php?mining-permits

Ferarri, J.R., T.R. Lookingbill, B. McCormick, P.A. Townsend, and K.N. Eshleman, 2009. Surface mining and reclamation effects on flood response of watersheds in the Central Appalachian Plateau region. Water Resources Research, 45, 1-11. 
Fernandez, C., J.Q. Wu, D.K. McCool, and C.O. Stöckle, 2003: Estimating water erosion and sediment yield with GIS, RUSLE, and SEDD. Journal of Soil and Water Conservation, 58(3), 128-136.

Finn, D. S., N. Bonada, C. Murria, and J. M. Hughes, 2011. Small but mighty: headwaters are vital to stream network biodiversity at two levels of organization. Journal of the North American Benthological Society 30: 963-980.

Fontaine, T.A., and V.M.F. Jacomino, 1997. Sensitivity analysis of simulated contaminated sediment transport. Journal of the American Water Resources Association, 33(2), 313326.

Fu, B.J., W.W. Zhao, L.D. Chen, Q.J. Zhang, Y.H. Lu, H. Gulinck, and J. Poesen, 2005. Assessment of soil erosion at large watershed scale using RUSLE and GIS: a case study in the Loess Plateau of China. Land Degradation \& Development, 16, 73-85.

Google Earth, 2014. Whitesville, WV. 3758'28.17” N, 81³1'45.62” W, eye alt 21.82 mi. Imagery date 1996. Retrieved from http://www.earth.google.com

GSE Environmental $^{\mathrm{TM}}$, 2014. Geomembrane Supported. Retrieved from: http://www.gseworld.com/Products/Geosynthetic-Clay-Liners/GeomembraneSupported/\#Pane2

Graves, D.H., J.M. Ringe, M.H. Pelkki, R.J. Sweigard, and R. Warner, 2000. High value tree reclamation research. In Environmental Issues and Management of Waste in Energy and Mineral Production. CRC Press: Boca Raton, FL, USA, pp. 413-421.

Green, J., M. Passmore, and H. Childers, 2000. A survey of the condition of streams in the primary region of mountaintop mining/valley fill coal mining. US Environmental Protection Agency: Philadelphia, PA.

Griffith, M.B., S.B. Norton, L.C. Alexander, A.L. Pollard, and S.D. LeDuc, 2012. The effects of mountaintop mines and valley fills on the physicochemical quality of stream ecosystems in the central Appalachians: A review. Science of the total environment, 417-418: 1-12.

Harms, N.J., and G.D. Fairhurst, G.R. Bortolotti, and J.E.G. Smits, 2010. Variation in immune function, body condition, and feather corticosterone in nestling Tree Swallows (Tachycineta bicolor) on reclaimed wetlands in the Athabasca oil sands, Alberta, Canada. Environmental Pollution, 158, 841-848. 
Hartman, K.J., M.D. Kaller, J.W. Howell, and J.A. Sweka, 2005. How much do valley fills influence headwater streams? Hydrobiologia, 532(1), 91-102.

Hoomehr, S., J.S. Schwartz, D. Yoder, E.C. Drumm, and W. Wright, 2015. Erodibility of lowcompaction steep-sloped reclaimed surface mine lands in the southern Appalachian region, USA. Hydrological Processes, 29, 321-338.

Hopkinson, L., J. Quaranta, M. Armstead, J. Hause, and N. Depriest, 2015a. Assessing geomorphic reclamation in valley fill design for West Virginia. Final report prepared under the U.S. Office of Surface Mining and Reclamation Enforcement, Cooperative Agreement No. S12AC20020, 54 p.

Hopkinson, L.C., A. Sears, M. Snyder, E. O’Leary, N. Depriest, J.D. Quaranta, and P.F. Ziemkiewicz, 2015b. Simulating the hydrologic response when streams are incorporated in valley fill design. International Journal of Mining, Reclamation, and Environment, in press.

Hunt, R.J., 1996. Do created wetlands replace the wetlands that are destroyed? U.S. Geological Survey, Fact Sheet FS-246-96.

Idcide, 2015. Whitesville, WV Weather. Retrieved from: www.idcide.com/weather/wv/whitesville.htm

Interagency Core Group, 1998. A handbook of constructed wetlands: A guide to creating wetlands for agricultural, wastewater, domestic wastewater, coal mine drainage, and stormwater in the Mid-Atlantic Region. Retrieved from http://water.epa.gov/type/wetlands/restore/upload/1998_04_02_wetlands_pdf_hand.pdf

Kenney, T.C., and D. Lau, 1985. Internal stability of granular filters. Canadian Geotechnical Journal, 22, 215-225.

Koerner, R. M., 1998. Designing with Geosynthetics, $4^{\text {th }}$ Ed. Prentice-Hall, Inc.

Kouli, M., P. Soupios, and F. Vallianatos, 2009. Soil erosion prediction using the Revised Soil Loss Equation (RUSLE) in a GIS framework, Chania, Northwestern Crete, Greece. Environmental Earth Sciences, 57, 483-497.

Kult, J., L. Fry, A. Gronewold, and W. Choi, 2015. Regionalization of hydrologic response in the Great Lakes basin: Considerations of temporal and spatial scales of analysis. Retrieved from: http://www.glerl.noaa.gov/pubs/posters/Kult_2012.pdf 
Laroche, A.J., R.L. Gallicharud, and A. Pesant, 1996. Simulating atrazine transport with HSP in an agricultural watershed. ASCE Journal of Environmental Engineering, July, 1996.

Lindberg, T.T., E.S. Berhardt, R. Bier, A.M. Helton, R.B. Merola, A. Vengosh, and R.T. Di Giulio, 2011. Cumulative impacts of mountaintop mining on an Appalachian watershed. Proceedings of the National Academy of Sciences of the United States of America, 108(52); 20929-20934.

Martin-Duque J.F., M.A. Sanz, J.M Bodoque, A. Lucia, and C. Martin-Moreno, 2010. Restoring earth surface processes through landform design: a 13-year monitoring of a geomorphic reclamation model for quarries on slopes. Earth Surface Processes and Landform, 35(5), 531-548.

Martin-Moreno, C., J.F. Martin-Duque, J.M. Nicolau, L. Sanchez, R. Ruiz, M. Sanz, A. Lucia, and I. Zapico, 2008. A geomorphic approach for the ecological restoration of kaolin mines at the Upper Tagus Natural Park (Spain). 6th European Conference on Ecological Restoration, Ghent, Belgium.

McIntosh, J.E., and R.I. Barnhisel, 1993. Erodibility and sediment yield by natural rainfall from reconstructed mine spoils. Journal of Soil Science, 156: 118-126.

Measles, D., N. and Bugosh, 2007. Making and building a fluvial geomorphic reclamation design at an active dragline mine using the GeoFluv ${ }^{\mathrm{TM}}$ design method. 30 Years of SMCRA and Beyond, Gillette, WY, ASMR.

Merriam, E. R., J. T. Petty, G. T. Merovich, J. B. Fulton, and M. P. Strager, 2011. Additive effects of mining and residential development on stream conditions in central Appalachian watershed. Journal of the North American Benthological Society 30: 399418.

Messinger, T., 2003. Comparison of storm response of streams in small, un-mined and valleyfilled watersheds. US Geological Survey Water-Resources Investigations Report, 024303, 1999-2001, Ballard Fork, WV, USGS.

Messinger, T., and K.S. Paybins, 2003. Relations between precipitation and daily and monthly mean flows in gaged, un-mined and valley-filled watersheds. US Geological Survey Water-Resources Investigations Report, 03-4113, 1999-2001, Ballard Fork, WV, USGS. 
Meyer, J. L., and J. B. Wallace, 2001. Lost linkages and lotic ecology: rediscovering small streams. In Press, M. C., N. J. Huntley, and S. Levin (eds), Ecology: Achievement and Challenge. Blackwell Science, Oxford, UK: 295-317.

Michael, P.R., M.J. Superfesky, and L.J. Uranowski, 2010. Challenges to applying the geomorphic and stream reclamation methodologies to mountaintop mining and excess spoil fill construction in steep-slope topography (e.g. Central Appalachia). Pittsburgh, PA Bridging Reclamation, Science and the Community, Lexington, KY, ASMR.

Miller, A.J., and N.P. Zegre, 2014. Mountaintop removal mining and catchment hydrology. Water, 6, 472-499.

Miller, J.O., A.D. Karathanasis, and C.J. Matocha, 2011. In situ generated colloid transport of $\mathrm{Cu}$ and $\mathrm{Zn}$ in reclaimed mine spoil profiles associated with biosolids application. Applied and Environmental Soil Science, 2011.

Natural Resources Conservation Service (NRCS), 2013. Web Soil Survey (WSS). U.S.

Department of Agriculture. Retrieved from http://websoilsurvey.sc.egov.usda.gov/App/HomePage.htm

Negley, T.L., and K.N. Eshleman, 2006. Comparison of storm flow responses of surface mined and forested watersheds in the Appalachian Mountains, USA. Hydrological Processes, 20(1), 3467-3483.

Nicolau, J.M., 2002. Runoff generation and routing on artificial slopes in a Mediterraneancontinental environment: the Teruel coalfield, Spain. Hydrological Processes, 16, 631647.

Northington, R.M., E.F. Benfield, S.H. Schoenholtz, A.J. Timpano, J.R. Webster, and C. Zipper, 2011. An assessment of structural attributes and ecosystem function in restored Virginia coalfield streams. Hydrobiologia, 671, 51-63.

Nyakatawa, E.Z., K.C. Reddy, and J.L. Lemunyon, 2001. Predicting soil erosion in conservation tillage cotton production systems using the revised soil loss equation. Soil \& Tillage Research, 57: 213-224.

O’Leary, E.E., 2014. Floodplain mapping in response to surface mine reclamation. Thesis. Morgantown, WV: WVU.

Palmer, M.A., E.S. Bernhardt, W.H. Schlesinger, K.N. Eshleman, E. Foufoula-Georgiou, Hendryx, A.D. Lemly, G.E. Likens, O.L. Loucks, M.E. Power, P.S. White, and P.R. 
Wilcock, 2010. Mountaintop mining consequences. Science (Washington), 327(5962), 148-149.

Palmer, M.A., and K.L. Hondula, 2014. Restoration as mitigation: analysis of stream mitigation for coal mining impacts in Southern Appalachia. Environmental Science \& Technology, 48, 10552-10560.

Petty, J. T., G. Gingerich, J. T. Anderson, and P. F. Ziemkiewicz, 2013. Ecological function of constructed perennial stream channels on reclaimed surface coal mines. Hydrobiologia 720:39-53.

Pokharel, S. K., J. Han, D. Leshchinsky, R. L. Parsons, and I. Halahm, 2010. Investigation of factors influencing behavior of single geocell-reinforced bases under static loading. Geotext Geomembranes 28; 570-578.

Pond, G.J., M.E. Passmore, F.A. Borsuk, L. Reynolds, and C.J. Rose, 2008. Downstream effects of mountaintop coal mining: comparing biological conditions using family and genuslevel macro-invertebrate bio-assessment tools. Journal of the North American Benthological Society (27)3, 717-737.

Quaranta, J. D., A. G. Mohammed, and J. J. Bowders, 1997. First-exposure performance of the bentonite component of a GCL in a low-pH, calcium-enriched environment. Testing of geosynthetic clay liners, ASTM STP 1308, Larry W. Well, Ed., American Society for Testing and Materials.

Rahe, N.H., K.W. Willard, and J.E. Schoonover, 2015. Restoration of riparian butter function in reclaimed surface mine soils. Journal of the American Water Resources Association, 51(4), 898-909.

Ranzi, R., T.H. Le, and M.C. Rulli, 2011. A RUSLE approach to model suspended sediment load in the Lo River (Vietnam): Effects of reservoirs and land use changes. Journal of Hydrology, 422-423(2012), 17-29.

Renard, K., G. Foster, G. Weesies, and J. Porter, 1991. RUSLE: revised universal soil loss equation. Soil and Water Conservation Society, 46(1), 30-33.

Renard, K., G. Foster, G. Wessies, D. McCool, and D. Yoder, 1997. Predicting soil erosion by water: A guide to conservation planning with the Revised Universal Soil Loss Equation (RUSLE). U.S. Department of Agriculture-Agriculture Handbook No. 703. 
Renard, K.G., J.M. Laflen, G.R. Foster, and D.K. McCool, 1994. The revised universal soil loss equation, in R. Lal (ed.) Soil Erosion Research Methods, $2^{\text {nd }}$ ed. Soil and Water Conservation Society, Ankeny, IA.

Renard, K.G., and J.R. Freimund, 1994. Using monthly precipitation data to estimate the Rfactor in the revised USLE, Journal of Hydrology, 157, 287-306.

Rosewell, C.J., and K. Edwards, 1988. SOILLOSS_A program to assist in the selection of management practices to reduce erosion. Soil Conservation Service of New South Wales, Technical Handbook, No. 11.

Rosgen, D.L. 1994. A classification of natural rivers. Catena, 22 (3): 169-199.

Russell, H., 2012. Soil and slope stability study of geomorphic landform profiles versus approximate original contour for valley fill designs. Master's thesis, West Virginia University, Morgantown, WV.

Russell, H., and J.D. Quaranta, 2013. Slope stability analysis of geomorphic landform profiles versus approximate original contour applied to valley-fill designs, Proc., Environmental Considerations in Energy Production, Society for Mining, Metallurgy, and Exploration, Charleston, WV, April 14-18.

Saylor, K.L., 2008. Land cover trends: Central Appalachians. U.S. Department of the Interior, U.S. Geological Survey (USGS), Washington, D.C. http://landcovertrends.usgs.gov/east/eco69Report.html

Schnoor, J.L. (Ed.), 2010. Mountaintop mining. Environmental Science \& Technology, 44(23), 8794-8794.

Sears, A.E., 2012. The integration of geomorphic design into West Virginia surface mine reclamation. Master's thesis, West Virginia University, Morgantown, WV.

Sears, A., C.J. Bise, J.D. Quaranta, and L.C. Hopkinson, 2013. Methodology for geomorphic landform design of valley-fills in Appalachia surface mine reclamation. Proc., Environmental Considerations in Energy Production, Society for Mining, Metallurgy, and Exploration, Charleston, WV, April 14-18.

Sears, A.E., C.J. Bise, J.D. Quaranta, and L.C. Hopkinson, 2014. Field and modeling study for stream mitigation on surface mine sites in West Virginia. Mining Engineering, 66(5), 4853. 
Sears, A., H. Russell, L. Hopkinson, and J.D. Quaranta, 2012. Incorporating fluvial geomorphic landform design in West Virginia. International Conference on Solid Waste Technology and Management, March 11-14. Philadelphia, PA.

Simanton, J.R., E. Rawitz, and E.D. Shirley, 1982. Effects of rock fragments on erosion of semiarid rangeland soils. Erosion and Productivity of Soils Containing Rock Fragments, Soil Science Society of America Special Publication, No. 13, pp. 65-72.

Singh, J., H.V. Knapp, and M. Demissie, 2004. Hydrologic modeling of the Iroquois River watershed using HSPF and SWAT. Illinois State Water Survey Contract Report 2004-08.

Snyder, M.W., 2013. Hydrologic response of alternative valley fill reclamation designs. Master's thesis, West Virginia University, Morgantown, WV.

TenCate, 2014. TenCate Geosynthetics: Geotextiles. Retrieved from: http://www.tencate.com/amer/geosynthetics/products/geotextiles/default.aspx

Townsend, P.A., D.P. Helmers, C.C. Kingdon, B.E. McNeil, K.M. de Beurs, and K.N. Eshleman, 2009. Changes in the extent of surface mining and reclamation in the Central Appalachians detected using 1796-2006 Landsat time series. Remote Sensing of Environment, (113), 62-72.

Toy, T.J., and W.R. Chuse, 2005. Topographic reconstruction: a geomorphic approach. Ecological Engineering, (24), 29-35.

Toy, T., G. Foster, and K. Renard, 1999. RUSLE for mining, construction and reclamation lands. Soil and Water Conservation Society, 54(2), 462-467.

USDA, 1951. Soil Survey Manual. Soil Survey Division Staff, US Department of Agriculture

USDA, 2014. Official Soil Series Descriptions (OSD), National Cooperative Soil Survey. US Department of Agriculture.

USEPA, 1999. HSPFParm: an interactive database of HSPF model parameters, Version 1.0. EPA-823-R-99-004. US Environmental Protection Agency, Office of Water, Washington, DC.

USEPA, 2000. BASINS Technical Note 6: Estimating hydrology and hydraulic parameters for HSPF. EPA-823-R00-012, US Environmental Protection Agency, Office of Water, Washington, DC. 
USEPA, 2005. Final Programmatic Environmental Impact Statement (PEIS) on mountaintop mining/valley fills in Appalachia. 2005 Final Report, EPA 9/03/R-05002, US Environmental Protection Agency, Washington, DC.

USEPA, 2011. The effects of mountaintop mines and valley fills on aquatic ecosystems of the Central Appalachian coalfields. 2011 Final Report, EPA/600/R-09/138F, US Environmental Protection Agency, Washington, DC.

USEPA, 2013. Level III ecoregions of the continental United States: Corvallis, Oregon, U.S. EPA - National Health and Environmental Effects Research Laboratory, map scale 1:7,500,000. Retrieved from http://www.epa.gov/wed/pages/ecoregions/level_iii_iv.htm

U.S. Climate Data, 2014. Climate Logan-West Virginia. Retrieved from http://www.usclimatedata.com/climate/logan/west-virginia/united-states/uswv0442

Wang, G., P. Hapurachchi, H. Ishidaira, A.S. Kiem, and K. Takeuchi, 2009. Estimation of soil erosion and sediment yield during individual rainstorms at catchment scale. Water Resources Management, 23, 1447-1465.

Warner, R., C.T. Agouridis, and C.D. Barton, 2009. Modeling Sediment Loss on Geomorphic Regraded Forest Lands in Kentucky. Proc. Geomorphic Reclamation and Natural Stream Design at Coal Mines: A Technical Interactive Forum, Office of Surface Mining Reclamation and Enforcement (OSMRE), Bristol, VA, April 27-30.

Wickham, J., P.B. Wood, M.C. Nicholson, W. Jenkins, D. Druckenbrod, G.W. Glenn, M.P. Strager, C. Mazzarella, W. Galloway, and J. Amos, 2013. The overlooked terrestrial impacts of mountaintop mining. Bioscience, 63(5), 335-348.

Wiley, J.B., and F.D. Brogan, 2003. Comparison of peak discharges among sites with and without valley fills for the July 8-9, 2001, flood in the headwaters of Clear Fork, Coal River Basin, mountaintop coal-mining region, southern West Virginia. U.S. Department of the Interior, Geological Survey: Charleston, WV, 1-16.

Wiley, J.B., R.D. Evaldi, J.H. Eychaner, and D.B. Chambers, 2001. Reconnaissance of stream geomorphology, low stream flow, and stream temperature in the mountaintop coalmining region, southern West Virginia. Water-Resources Investigations Report 014092, USGS, 1999-2000.

Wischmeier, W.H. and D.D. Smith, 1978. Predicting rainfall erosion losses-a guide to conservation planning. U.S. Department of Agriculture, Agriculture Handbook No. 537. 
WVDEP, 1993. Technical handbook: Standards and specifications for erosion and sediment control excess spoil disposal haulages, West Virginia Department of Environmental Protection, Division of Mining and Reclamation.

WVDEP, 2011. Permit ID S500809 Coal-Mac, Inc. Pine Creek No. 2 Surface Mine.

WVDEP TAGIS, 2014. West Virginia Department of Environmental Protection Technical Applications and GIS Unit (WVDEP TAGIS) Data Download: Mining Permit Shapefiles: Excess Spoil (Valley Fills). Retrieved from http://tagis.dep.wv.gov/home/Downloads WVOMHST, 2012. West Virginia coal mining facts. West Virginia Office of Miners' Health, Safety, and Training. Retrieved from http://www.wvminesafety.org/wvcoalfacts.htm WVOMHST, 2015. West Virginia Mining Statistics 1996-2012: 2013 West Virginia Statistical Data. West Virginia Office of Miners' Health Safety and Training, 2015. Retrieved from http://www.wvminesafety.org/STATS.HTM

Yao, C., T. Lei, W.J. Elliot, D.K. McCool, J. Zhao, and S. Chen, 2008. Critical conditions for rill initiation. Transactions of the ASABE, 51, 107-114.

Yu, B., and C.J. Rosewell, 1996. A robust estimator of the R-factor for the Universal Soil Loss Equation. American Society of Agricultural Engineers, 39(2), 559-561.

Zhang, J., H. Gong, X. Li, and M. Ross, 2009. Effects of mining on the ecosystems integrating GIS and hydrological model. Proc., $17^{\text {th }}$ International Conference on Geoinformatics Institute of Electrical and Electronics Engineers, Fairfax, VA, August 12-14.

Zhang, L., M. Zhao, C. Shi, and H. Zhao, 2010. Bearing capacity of geocell reinforcement in embarkment engineering. Geotextiles and Geomembranes, 28, 475-482.

Zhou, H. B., and X. J. Wen, 2008. Model studies on geogrid- or geocell-reinforced sand mattress on soft soil. Geotext Geomembranes 26, 231-238. 


\section{Grant Information}

The project described in this publication was supported by Grant/Cooperative Agreement Number G12AP20156 from the United States Geological Survey. Its contents are solely the responsibility of the authors and do not necessarily represent the official views of the USGS. 


\section{Appendix A: HSPF land use/land cover areas within each subwatershed}

Table A.1. HSPF land use/land cover areas within each subwatershed

\begin{tabular}{|c|c|c|c|c|}
\hline Source ID & Source Description & Target ID & Subwatershed & Area (ac) \\
\hline PERLND 101 & Urban or Built-up Land & RCHRES 1 & 1 & 1.3 \\
\hline IMPLND 101 & Urban or Built-up Land & RCHRES 1 & 1 & 1.3 \\
\hline PERLND 102 & Agricultural Land & RCHRES 1 & 1 & 64.8 \\
\hline PERLND 103 & Forest Land & RCHRES 1 & 1 & 3781.7 \\
\hline PERLND 104 & Barren Land & RCHRES 1 & 1 & 29.5 \\
\hline PERLND 101 & Urban or Built-up Land & RCHRES 2 & 2 & 23.8 \\
\hline IMPLND 101 & Urban or Built-up Land & RCHRES 2 & 2 & 23.8 \\
\hline PERLND 103 & Forest Land & RCHRES 2 & 2 & 6500.4 \\
\hline PERLND 104 & Barren Land & RCHRES 2 & 2 & 143.9 \\
\hline PERLND 102 & Agricultural Land & RCHRES 3 & 3 & 139.2 \\
\hline PERLND 103 & Forest Land & RCHRES 3 & 3 & 3048.2 \\
\hline PERLND 104 & Barren Land & RCHRES 3 & 3 & 171.9 \\
\hline PERLND 101 & Urban or Built-up Land & RCHRES 4 & 4 & 44.4 \\
\hline IMPLND 101 & Urban or Built-up Land & RCHRES 4 & 4 & 44.4 \\
\hline PERLND 102 & Agricultural Land & RCHRES 4 & 4 & 46.4 \\
\hline PERLND 103 & Forest Land & RCHRES 4 & 4 & 2006.4 \\
\hline PERLND 105 & Wetlands/Water & RCHRES 4 & 4 & 23.1 \\
\hline PERLND 104 & Barren Land & RCHRES 4 & 4 & 478.2 \\
\hline PERLND 102 & Agricultural Land & RCHRES 5 & 5 & 166 \\
\hline PERLND 103 & Forest Land & RCHRES 5 & 5 & 5598.4 \\
\hline PERLND 104 & Barren Land & RCHRES 5 & 5 & 748.2 \\
\hline PERLND 101 & Urban or Built-up Land & RCHRES 6 & 6 & 11.8 \\
\hline IMPLND 101 & Urban or Built-up Land & RCHRES 6 & 6 & 11.8 \\
\hline PERLND 102 & Agricultural Land & RCHRES 6 & 6 & 111.7 \\
\hline PERLND 103 & Forest Land & RCHRES 6 & 6 & 1571.6 \\
\hline PERLND 104 & Barren Land & RCHRES 6 & 6 & 97.5 \\
\hline PERLND 101 & Urban or Built-up Land & RCHRES 7 & 7 & 6 \\
\hline IMPLND 101 & Urban or Built-up Land & RCHRES 7 & 7 & 6 \\
\hline PERLND 102 & Agricultural Land & RCHRES 7 & 7 & 5.5 \\
\hline PERLND 103 & Forest Land & RCHRES 7 & 7 & 1620.5 \\
\hline PERLND 101 & Urban or Built-up Land & RCHRES 8 & 8 & 63.6 \\
\hline IMPLND 101 & Urban or Built-up Land & RCHRES 8 & 8 & 63.6 \\
\hline PERLND 102 & Agricultural Land & RCHRES 8 & 8 & 139.4 \\
\hline PERLND 103 & Forest Land & RCHRES 8 & 8 & 6223.3 \\
\hline PERLND 104 & Barren Land & RCHRES 8 & 8 & 1364 \\
\hline PERLND 101 & Urban or Built-up Land & RCHRES 9 & 9 & 85.3 \\
\hline IMPLND 101 & Urban or Built-up Land & RCHRES 9 & 9 & 85.3 \\
\hline PERLND 103 & Forest Land & RCHRES 9 & 9 & 6485.9 \\
\hline PERLND 104 & Barren Land & RCHRES 9 & 9 & 183.2 \\
\hline
\end{tabular}




\section{Appendix B: HSPF Calibration Parameters}

\section{B1: HSPF parameters for simulation of pervious land segments (PERLNDs), group 1 subroutine named "PWATER" used in this study for Clear Fork Watershed at Whitesville, WV: (HSPF Manual v. 12.2; Atkins et al., 2005)}

CSNOFG was chosen to be 1 because snow accumulation and melt are being considered. Therefore, HSPF will expect the time series produced by the section SNOW are available either internally or from external sources.

RTOPFG selects the algorithm for computing overland flow. RTOPFG was selected to be 1 due to routing of overland flow being done the same way as in predecessor models HSPX, ARM, and NPS.

UZFG selects the method for computing inflow to the upper zone. UZFG was determined to be 1 due to the upper zone inflow being computed in the same way as in the predecessor models HSPX, ARM, and NPS.

Parameters flags beginning with "V" indicate whether or not the parameters will vary on a monthly basis as opposed to a yearly or daily basis. If the parameter flag is chosen to be 1 , the parameter will vary on a monthly basis. If the parameter flag is chosen to be 0 , the parameter will not vary on a monthly basis.

VCSFG determines if the interception storage capacity varies on a monthly basis. The interception storage capacity was chosen to vary on a monthly basis for agricultural land, forest land, wetland/water, and barren/mined land but VCSFG was chosen to not vary monthly for urban/developed land.

VUZFG determines if the upper zone nominal storage varies on a monthly basis. The upper zone nominal storage was chosen to vary on a monthly basis for agricultural land and forest land, but VUZFG was chosen to not vary monthly for wetland/water, and barren/mined land urban/developed land.

VNNFG determines if Manning's $\mathrm{n}$ for the overland flow plane varies on a monthly basis. Manning's $\mathrm{n}$ for the overland flow plane was chosen to not vary on a monthly basis for all landuse/land cover types used for this analysis.

VIFWFG determines if the interflow inflow parameter varies on a monthly basis. The interflow inflow parameter was chosen to not vary on a monthly basis for all landuse/land cover types used for this analysis.

VIFCFG determines if the interflow recession constant varies on a monthly basis. The interflow recession constant was chosen to not vary on a monthly basis for all landuse/land cover types used for this analysis. 
VLEFG determines if the lower zone evapotranspiration (E-T) parameter varies on a monthly basis. The lower zone evapotranspiration (E-T) parameter was chosen to vary on a monthly basis for all landuse/land cover types used for this analysis. Therefore, monthly values for the lower zone evapotranspiration (E-T) parameter must be supplied in the corresponding monthly table.

IFFCFG determines if the effect of frozen ground on the infiltration rate is computed from the amount of ice in the snow pack (PACKI). The effect of frozen ground on the infiltration rate was chosen to be computed from the amount of ice in the snow pack for all landuse/land cover typed used for this analysis.

HWTFG determines if the high water table and low land surface gradient conditions (i.e. wetlands) are prevalent on the land segment. The high water table and low land surface gradient conditions were determined to not be prevalent on the land segment for all landuse/land cover types except the wetland/water type.

IRRGFG determines if the irrigation module will be used and selects the method used to determine demands in the irrigation module. The irrigation module was chosen to not be used for this simulation for any of the landuse/land cover types.

IFRGFG determines which method of infiltration distribution is used. The standard method of infiltration distribution was chosen to be used for this analysis for all of the landuse/land cover types.

Table B.1. HSPF parameters for simulation of pervious land segments (PERLNDs), group 1 subroutine named "PWATER" used in this study for Clear Fork Watershed at Whitesville, WV

\begin{tabular}{|c|c|c|c|c|c|c|c|c|c|c|c|c|c|c|}
\hline \multicolumn{15}{|c|}{ PERLND: PWAT-PARMI } \\
\hline PERLND Number & Landuse/Land Corer & $\begin{array}{l}\text { CSNOFG } \\
\end{array}$ & RTOPFG & UZFG & VCSEG & VUZFG & $\begin{array}{l}\text { VNNFG } \\
\end{array}$ & VIRWFG & $\begin{array}{l}\text { VIRCFG } \\
\end{array}$ & $\begin{array}{l}\text { VLEFG } \\
\end{array}$ & IFFCFG & HWTFG & IRRGFG & IFRDFG \\
\hline 101 & Urban Developed & 1 & 1 & 1 & 0 & 0 & 0 & $\frac{111 \text { Parameters are }}{0}$ & dimensionless. & 1 & 1 & 0 & 0 & 0 \\
\hline 102 & Agricultural Land & 1 & 1 & 1 & 1 & 1 & 0 & 0 & 0 & 1 & 1 & 0 & 0 & 0 \\
\hline 103 & Forest Land & 1 & 1 & 1 & 1 & 1 & 0 & 0 & 0 & 1 & 1 & 0 & 0 & 0 \\
\hline 104 & Wetland/Water & 1 & 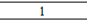 & 1 & 1 & 0 & 0 & 0 & 0 & 1 & 1 & 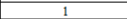 & 0 & 0 \\
\hline 105 & Barren/Mined Land & 1 & 1 & 1 & 1 & 0 & 0 & 0 & 0 & 1 & 1 & 0 & 0 & 0 \\
\hline Parameter Description & & \begin{tabular}{|c|} 
determines if \\
snow \\
accumulation and \\
melt are being \\
considered \\
\end{tabular} & $\begin{array}{l}\text { selects the } \\
\text { algorithm for } \\
\text { computing } \\
\text { overland flow }\end{array}$ & $\begin{array}{l}\text { selects the } \\
\text { method for } \\
\text { computing } \\
\text { irflow to the } \\
\text { upper zone }\end{array}$ & \begin{tabular}{|c|} 
determines if the \\
interception \\
storage capacity \\
varies on a \\
monthly basis \\
\end{tabular} & $\begin{array}{c}\text { determines if the } \\
\text { upper zone } \\
\text { nominal storage } \\
\text { varies on a } \\
\text { monthly basis }\end{array}$ & \begin{tabular}{|c|} 
determines if \\
Manning's nfor the \\
overland flow plane \\
varies on a monthly \\
basis \\
\end{tabular} & $\begin{array}{c}\text { determines if the } \\
\text { interflow inflow } \\
\text { parameter varies } \\
\text { on a monthly } \\
\text { basis } \\
\end{array}$ & $\begin{array}{c}\text { determines if the } \\
\text { interflow } \\
\text { recession } \\
\text { constant varies } \\
\text { on a monthly } \\
\text { basis } \\
\end{array}$ & \begin{tabular}{|c|} 
determines if the \\
lower zone \\
evapotranspiratio \\
$\mathrm{n}(\mathrm{E}-\mathrm{T})$ parameter \\
varies on a \\
monthly basis \\
\end{tabular} & \begin{tabular}{|c|}
$\begin{array}{c}\text { determines if the } \\
\text { effect of frozen } \\
\text { ground on infiltration } \\
\text { rate is computed from } \\
\text { amount of ice in } \\
\text { snow pack }\end{array}$ \\
\end{tabular} & \begin{tabular}{|c|} 
detemines if the high \\
water table and low \\
land surface gradient \\
conditions are \\
prevalent on the land \\
segment
\end{tabular} & \begin{tabular}{|c} 
determines if \\
irigation module is \\
used and selects \\
method used to \\
determine demands \\
in irigation module \\
\end{tabular} & \begin{tabular}{|c|} 
determines which \\
method of \\
infiltration \\
distribution is \\
used
\end{tabular} \\
\hline Flag Description & & $\begin{array}{l}\text { 1=SNOW } \\
\text { considered }\end{array}$ & $\begin{array}{l}1=\text { same as } \\
\text { predecessor }\end{array}$ & $\begin{array}{l}1=\text { same as } \\
\text { predecessor }\end{array}$ & $1=$ yes, $0=$ no & $1=$ yes, $0=$ no & $0=n o$ & $0=n o$ & $0=$ no & 1 =yes & 1 =yes & $1=y e s, 0=$ no & $0=$ no & $0=$ standard method \\
\hline
\end{tabular}

HSPF parameters for simulation of pervious land segments (PERLNDs), group 2 subroutine named "PWATER" used in this study for Clear Fork Watershed at Whitesville, WV: (HSPF Manual v. 12.2; Atkins et al., 2005)

Studies determining the types of vegetative cover, fraction of land covered by forest transpiring in winter, soil properties, and flow and storage values have not been performed at the Clear Fork 
watershed at Whiteville, WV. Therefore, group 2 subroutine "PWATER" values were taken from the USGS calibration parameters for the Clear Fork at Clear Fork, WV analysis in HSPF (Atkins et al., 2005). This was determined to be acceptable due to the close proximity of the two watersheds (approximately 38 miles), similar topography, and surface mining occurring in both watersheds.

FOREST is the fraction of pervious land segment which is covered by forest transpiring in winter and is only relevant if the SNOW module is being considered.

LZSN is the lower zone nominal storage.

INFILT is an index to the infiltration capacity of the soil.

LSUR is the length of the assumed overland flow plane.

SLSUR is the slope of the overland flow plane.

KVARY is a parameter which affects the behavior of groundwater recession flow, enabling it to be non-exponential in its decay with time.

AGWRC is the interflow recession parameter. If inflow is zero, AGWRC is the rate of flow today divided by the rate of flow yesterday.

Table B.2. HSPF parameters for simulation of pervious land segments (PERLNDs), group 2 subroutine named "PWATER" used in this study for Clear Fork Watershed at Whitesville, WV

PERLND: PWAT-PARM2

\begin{tabular}{|c|c|c|c|c|c|c|c|c|}
\hline PERLND Number & Landuse/Land Cover & FOREST & LZSN & INFILT & LSUR & SLSUR & KVARY & AGWRC \\
\hline & & dimensionless & (in) & (in/day) & (ft) & $(\mathrm{ft} / \mathrm{ft})$ & (1/in) & (1/in) \\
\hline 101 & Urban/Developed & 0.1 & 1 & 0.001 & 50 & 0.08 & 2.5 & 0.97 \\
\hline 102 & Agricultural Land & 0.1 & 5 & 0.034 & 300 & 0.5689 & 2.5 & 0.97 \\
\hline 103 & Forest Land & 0.1 & 3 & 0.035 & 200 & 0.5689 & 2.5 & 0.97 \\
\hline 104 & Wetland/Water & 0.1 & 5 & 0.03 & 50 & 0.3 & 2.5 & 0.97 \\
\hline 105 & Barren/Mined Land & 0 & 5 & 0.16 & 200 & 0.5689 & 2.5 & 0.97 \\
\hline Parameter Description & & $\begin{array}{l}\text { fraction of pervious } \\
\text { land segment which } \\
\text { is covered by forest } \\
\text { transpiring in winter }\end{array}$ & $\begin{array}{c}\text { lower zone } \\
\text { nominal storage }\end{array}$ & $\begin{array}{l}\text { index to the } \\
\text { infiltration } \\
\text { capacity of the } \\
\text { soil }\end{array}$ & $\begin{array}{c}\text { length of the } \\
\text { assumed overland } \\
\text { flow plane }\end{array}$ & $\begin{array}{c}\text { slope of the overland } \\
\text { flow plane }\end{array}$ & $\begin{array}{l}\text { affects the behavior of } \\
\text { groundwater recession } \\
\text { flow, enabling it to be } \\
\text { non-exponential in its } \\
\text { decay with time }\end{array}$ & $\begin{array}{c}\text { interflow recession } \\
\text { parameter }\end{array}$ \\
\hline
\end{tabular}




\section{HSPF parameters for simulation of pervious land segments (PERLNDs), group 3}

subroutine named "PWATER" used in this study for Clear Fork Watershed at Whitesville, WV: (HSPF Manual v. 12.2; Atkins et al., 2005)

PETMAX is the air temperature below which E-T will be reduced below the value obtained from the input time series and is only relevant if the SNOW module is being considered. PETMAX was chosen to be $40^{\circ} \mathrm{F}$ which is suggested by HSPF documentation.

PETMIN is the air temperature below which E-T will be zero regardless of the value in the input time series and is only relevant if the SNOW module is being considered. PETMIN was chosen to be $35^{\circ} \mathrm{F}$ which is suggested by HSPF documentation.

INFEXP is the exponent in the infiltration equation. INFEXP was chosen to be 2, which is suggested by HSPF documentation.

INFILD is the ratio between the maximum and mean infiltration capacities over the pervious land segment (PLS). INFILD was chosen to be 2, which is suggested by HSPF documentation.

DEEPFR is the fraction of groundwater inflow which will enter deep (inactive) groundwater and be lost from the system as it is defined in HSPF. DEEPFR was chosen to be 0 , which is suggested by HSPF documentation.

BASETP is the fraction of remaining potential E-T which can be satisfied from baseflow (groundwater outflow) if enough is available. BASETP was chosen to be 0 , which is suggested by HSPF documentation.

AGWETP is the fraction of remaining potential E-T which can be satisfied from active groundwater storage if enough is available. AGWETP was chosen to be 0 , which is suggested by HSPF documentation.

Table B.3. HSPF parameters for simulation of pervious land segments (PERLNDs), group 3 subroutine named "PWATER" used in this study for Clear Fork Watershed at Whitesville, WV

PERLND: PWAT-PARM3

\begin{tabular}{|c|c|c|c|c|c|c|c|c|}
\hline PERLND Number & Landuse/Land Cover & PETMAX & PETMIN & INFEXP & INFILD & DEEPFR & BASETP & AGWETP \\
\hline & & $\left({ }^{\circ} \mathrm{F}\right)$ & $\left({ }^{\circ} \mathrm{F}\right)$ & dimensionless & dimensionless & dimensionless & dimensionless & dimensionless \\
\hline 101 & Urban/Developed & 40 & 35 & 2 & 2 & 0 & 0 & 0 \\
\hline 102 & Agricultural Land & 40 & 35 & 2 & 2 & 0 & 0 & 0 \\
\hline 103 & Forest Land & 40 & 35 & 2 & 2 & 0 & 0 & 0 \\
\hline 104 & Wetland/Water & 40 & 35 & 2 & 2 & 0 & 0 & 0 \\
\hline 105 & Barren/Mined Land & 40 & 35 & 2 & 2 & 0 & 0 & 0 \\
\hline & & & & & & & & \\
\hline Parameter Description & & $\begin{array}{l}\text { air temperature } \\
\text { below which E-T } \\
\text { will be reduced } \\
\text { below the value } \\
\text { obtained from the } \\
\text { input time series }\end{array}$ & $\begin{array}{l}\text { air temperature } \\
\text { below which E-T } \\
\text { will be zero } \\
\text { regardless of the } \\
\text { value in the input } \\
\text { time series }\end{array}$ & $\begin{array}{l}\text { exponent in the } \\
\text { infiltration } \\
\text { equation }\end{array}$ & $\begin{array}{l}\text { atio between the } \\
\text { maximum and } \\
\text { mean infiltration } \\
\text { capacities over the } \\
\text { PLS }\end{array}$ & $\begin{array}{l}\quad \text { fraction of } \\
\text { groundwater inflow } \\
\text { that will enter deep } \\
\text { groundwater and be } \\
\text { lost from the system }\end{array}$ & $\begin{array}{c}\text { fraction of remaining } \\
\text { potential E-T whch can } \\
\text { be satisfied from } \\
\text { baseflow }\end{array}$ & $\begin{array}{c}\text { fraction of } \\
\text { remaining potential } \\
\text { E-T whch can be } \\
\text { satisfied from active } \\
\text { groundwater } \\
\text { storage }\end{array}$ \\
\hline
\end{tabular}


HSPF parameters for simulation of pervious land segments (PERLNDs), group 4 subroutine named "PWATER" used in this study for Clear Fork Watershed at Whitesville, WV: (HSPF Manual v. 12.2; Atkins et al., 2005)

Values in group 4 subroutine named "PWATER" should only be supplied for parameters which do not vary through the year.

Studies determining flow and storage properties/values have not been performed at the Clear Fork watershed at Whiteville, WV. Therefore, group 2 subroutine "PWATER" values were taken from the USGS calibration parameters for the Clear Fork at Clear Fork, WV analysis in HSPF (USGS, 2005). This was determined to be acceptable due to the close proximity of the two watersheds (approximately 38 miles), similar topography, and surface mining occurring in both watersheds.

CEPSC is the interception storage capacity.

UZSN is the upper zone nominal storage.

NSUR is Manning's $\mathrm{n}$ for the overland flow plane.

INTFW is the interflow inflow parameter

IRC is the interflow recession parameter. Under zero inflow, this is the ratio of today's interflow outflow rate to yesterday's rate.

LZTP is the lower zone E-T parameter. It is an index to the density of deep-rooted vegetation.

Table B.4. HSPF parameters for simulation of pervious land segments (PERLNDs), group 4 subroutine named "PWATER" used in this study for Clear Fork Watershed at Whitesville, WV

PERLND: PWAT-PARM4

\begin{tabular}{|c|c|c|c|c|c|c|c|}
\hline PERLND Number & Landuse/Land Cover & CEPSC & UZSN & NSUR & INTFW & IRC & LZETP \\
\hline & & (in) & (in) & dimensionless & dimensionless & (1/day) & dimensionless \\
\hline 101 & Urban/Developed & 0 & 0.2 & 0.02 & 0.5 & 0.02 & 0.228 \\
\hline 102 & Agricultural Land & 0.203 & 0.223 & 0.2 & 2.1 & 0.09 & 0.228 \\
\hline 103 & Forest Land & 0.024 & 0.223 & 0.35 & 2.5 & 0.1 & 0.402 \\
\hline 104 & Wetland/Water & 0.203 & 1.128 & 0.2 & 0.75 & 0.05 & 0.228 \\
\hline 105 & Barren/Mined Land & 0.203 & 1.128 & 0.02 & 0.05 & 0.05 & 0.228 \\
\hline Parameter Description & & $\begin{array}{c}\text { interception sorage } \\
\text { capacity }\end{array}$ & $\begin{array}{c}\text { upper zone } \\
\text { nominal storage }\end{array}$ & $\begin{array}{l}\text { Manning's } n \text { for } \\
\text { the overland flow } \\
\text { plane }\end{array}$ & $\begin{array}{l}\text { interflow inflow } \\
\text { parameter }\end{array}$ & $\begin{array}{l}\text { interflow recession } \\
\text { parameter }\end{array}$ & $\begin{array}{c}\text { lower zone } \mathrm{E}-\mathrm{T} \\
\text { parameter }\end{array}$ \\
\hline
\end{tabular}


HSPF parameters for simulation of air temperature (ATEMP), subroutine named "ATEMP-DAT" used in this study for Clear Fork Watershed at Whitesville, WV: (HSPF Manual v. 12.2; Atkins et al., 2005)

ELDAT is the difference in elevation between the temperature gage and the PERLND and is used to estimate the temperature over the segment by application of a lapse rate. ELDAT is positive if the segment is higher than the gage and is negative if the segment is lower than the gage. An elevation of the PERLND was determined to be $923 \mathrm{ft}$ and the elevation of the gage at Whitesville, WV was determined to be $823 \mathrm{ft}$. Therefore, ELDAT was estimated to be $100 \mathrm{ft}$.

AIRTMP is the initial air temperature over the land segment at the starting time of the RUN. The average air temperature was determined to be $72.5^{\circ} \mathrm{F}$ for Whitesville, WV for the month of June (Weather, 2014).

Table B.5. HSPF parameters for simulation of air temperature (ATEMP), subroutine named "ATEMP-DAT" used in this study for Clear Fork Watershed at Whitesville, WV

PERLND: ATEMP-DAT

\begin{tabular}{|c|c|c|c|}
\hline PERLND Number & Landuse/Land Cover & ELDAT & AIRTMP \\
\hline & & $(\mathbf{f t})$ & $\left({ }^{\circ} \mathbf{F}\right)$ \\
\hline 101 & Urban/Developed & 100 & 72.5 \\
\hline 102 & Agricultural Land & 100 & 72.5 \\
\hline 103 & Forest Land & 100 & 72.5 \\
\hline 104 & Wetland/Water & 100 & 72.5 \\
\hline 105 & Barren/Mined Land & 100 & 72.5 \\
\hline & & & \\
\hline & & $\begin{array}{c}\text { difference in } \\
\text { Parametevation between } \\
\text { the temperature } \\
\text { gage and the } \\
\text { PERLND }\end{array}$ & $\begin{array}{c}\text { initial air } \\
\text { temperature over } \\
\text { the land segment } \\
\text { athe starting time } \\
\text { of the RUN }\end{array}$ \\
\hline
\end{tabular}

HSPF parameters for simulation of snow (SNOW): (HSPF v.12.2; HSPF Manual v. 12.2; Atkins et al., 2005)

Studies determining the types of vegetative cover, fraction of land shaded from solar radiation, and the maximum snowpack have not been performed at the Clear Fork watershed at Whiteville, WV. Therefore, subroutine "SNOW" values were taken from the default values provided by the HSPF program (version 12.2), from values suggested by the HSPF manual v. 12.2, or from USGS calibration parameters for the Clear Fork at Clear Fork, WV analysis in HSPF (Atkins et al., 2005). This was determined to be acceptable due to the close proximity of the two watersheds (approximately 38 miles), similar topography, and surface mining occurring in both watersheds. 
HSPF parameters for simulation of snow (SNOW), subroutine named "ICE-FLAG" used in this study for Clear Fork Watershed at Whitesville, WV: (HSPF v.12.2; HSPF Manual v. 12.2; Atkins et al., 2005)

ICEFG determines if the ice formation in the snow pack will be simulated or not. 0 means that the ice formation will not be simulated and 1 means that ice formation will be simulated.

Table B.6. HSPF parameters for simulation of snow (SNOW), subroutine named "ICEFLAG" used in this study for Clear Fork Watershed at Whitesville, WV

PERLND: ICE-FLAG

\begin{tabular}{|c|c|c|}
\hline PERLND Number & Landuse/Land Cover & ICEFG \\
\hline 101 & Urban/Developed & 0 \\
\hline 102 & Agricultural Land & 0 \\
\hline 103 & Forest Land & 0 \\
\hline 104 & Wetland/Water & 0 \\
\hline 105 & Barren/Mined Land & 0 \\
\hline & & \\
\hline Parameter Description & & $\begin{array}{c}\text { determines if ice } \\
\text { formation in the } \\
\text { snow pack will be } \\
\text { simulated or not }\end{array}$ \\
\hline Flag Description & & $0=$ no \\
\hline
\end{tabular}

HSPF parameters for simulation of snow (SNOW), subroutine named "SNOW-FLAGS" used in this study for Clear Fork Watershed at Whitesville, WV: (HSPF v.12.2; HSPF Manual v. 12.2; Atkins et al., 2005)

SNOPFG selects the method for computing snowmelt. 0 means the energy balance method will be used, requiring input of air temperature, wind, dewpoint, and solar radiation. 1 means the temperature index method will be used, requiring only air temperature.

VKMFG determines if the degree-day factor KMELT used in the temperature index method is assumed to vary through the year on a monthly basis. 0 means that KMELT does not vary and 1 means that KMELT does vary. 
Table B.7. HSPF parameters for simulation of snow (SNOW), subroutine named "SNOWFLAG" used in this study for Clear Fork Watershed at Whitesville, WV

PERLND: SNOW-FLAG

\begin{tabular}{|c|c|c|c|}
\hline PERLND Number & Landuse/Land Cover & SNOPFG & VKMFG \\
\hline & & \multicolumn{2}{|c|}{ dimensionless } \\
\hline 101 & Urban/Developed & 0 & 0 \\
\hline 102 & Agricultural Land & 0 & 0 \\
\hline 103 & Forest Land & 0 & 0 \\
\hline 104 & Wetland/Water & 0 & 0 \\
\hline 105 & Barren/Mined Land & 0 & 0 \\
\hline Parameter Description & & $\begin{array}{l}\text { selects the method } \\
\text { for computing } \\
\text { snowmelt }\end{array}$ & $\begin{array}{l}\text { KMELT used in } \\
\text { the temperature } \\
\text { index method will } \\
\text { vary on a monthly } \\
\text { basis }\end{array}$ \\
\hline Flag Description & & $\begin{array}{c}0=\text { energy balance } \\
\text { method }\end{array}$ & $0=$ no \\
\hline
\end{tabular}

HSPF parameters for simulation of snow (SNOW), subroutine named "SNOW-PARM1" used in this study for Clear Fork Watershed at Whitesville, WV: (HSPF v.12.2; HSPF Manual v. 12.2; Atkins et al., 2005)

LAT is the latitude of the pervious land segment (PLS). LAT is positive for the northern hemisphere and negative for the southern hemisphere. LAT is only used when SNOPFG=0.

MELEV is the mean elevation of the PLS above sea level. MELEV is only used when $\mathrm{SNOPFG}=0$.

SHADE is the fraction of the PLS which is shaded from solar radiation, by trees or other objects. SHADE is only used when $\mathrm{SNOPFG}=0$.

SNOWCF is the factor by which the input precipitation data will be multiplied, if the simulation indicates it is snowfall, to account for poor catch efficiency of the gage under snow conditions.

COVIND is the maximum snowpack (water equivalent) at which the entire PLS will be covered with snow.

KMELT is the constant degree-day factor for the temperature index snowmelt method, to be used when $\mathrm{SNOPFG}=1$ and $\mathrm{VKMFG}=0$.

TBASE is the reference temperature for the temperature index method when SNOPFG=1. 
Table B.8. HSPF parameters for simulation of snow (SNOW), subroutine named "SNOWPARM1" used in this study for Clear Fork Watershed at Whitesville, WV

PERLND: SNOW-PARMI

\begin{tabular}{|c|c|c|c|c|c|c|c|c|}
\hline PERLND Number & Landuse/Land Cover & LAT & MELEV & SHADE & SNOWCF & COVIND & KMELT & TBASE \\
\hline & & $\left({ }^{\circ}\right)$ & (ft) & dimensionless & dimensionless & (in) & $\left(\right.$ in/day $\left.{ }^{* 0} F\right)$ & $\left({ }^{\circ} \mathrm{F}\right)$ \\
\hline 101 & Urban/Developed & 38 & 900 & 0.3 & 1.5 & 0.01 & 0 & 32 \\
\hline 102 & Agricultural Land & 38 & 900 & 0.3 & 1.5 & 0.01 & 0 & 32 \\
\hline 103 & Forest Land & 38 & 900 & 0.3 & 1.5 & 0.01 & 0 & 32 \\
\hline 104 & Wetland/Water & 38 & 900 & 0.3 & 1.5 & 0.01 & 0 & 32 \\
\hline 105 & Barren/Mined Land & 38 & 900 & 0.3 & 1.5 & 0.01 & 0 & 32 \\
\hline Parameter Description & & $\begin{array}{c}\text { latitude of the } \\
\text { pervious land } \\
\text { segment }\end{array}$ & $\begin{array}{c}\text { mean elevation of } \\
\text { the pervious land } \\
\text { segment }\end{array}$ & $\begin{array}{l}\text { the fraction of the } \\
\text { pervious land } \\
\text { segmetn which is } \\
\text { shaded from solar } \\
\text { radiation }\end{array}$ & $\begin{array}{c}\text { factor by which the } \\
\text { input precipitation } \\
\text { data will be multiplied } \\
\text { to account for poor } \\
\text { catch efficiency of the } \\
\text { gage under snow } \\
\text { conditions }\end{array}$ & $\begin{array}{l}\text { maximum snowpack } \\
\text { at which the entire } \\
\text { pervious land } \\
\text { segment will be } \\
\text { covered by snow }\end{array}$ & $\begin{array}{l}\text { the constant degree- } \\
\text { day factor for the } \\
\text { temperature index } \\
\text { snowmelt method }\end{array}$ & $\begin{array}{c}\text { reference } \\
\text { temperature for the } \\
\text { temperature index } \\
\text { method }\end{array}$ \\
\hline Flag Description & & & & & & & 0 if $\mathrm{SNOPG}=0$ & \\
\hline
\end{tabular}

HSPF parameters for simulation of snow (SNOW), subroutine named "SNOW-PARM2" used in this study for Clear Fork Watershed at Whitesville, WV: (HSPF v.12.2; HSPF Manual v. 12.2; Atkins et al., 2005)

RDCSN is the density of cold, new snow relative to water. RDCSN applies to snow falling at air temperatures lower than or equal to $0^{\circ} \mathrm{F}$. At higher temperature, the density of snow is adjusted.

TSNOW is the air temperature below which precipitation will be snow under saturated conditions. Under non-saturated conditions, the temperature is adjusted slightly.

SNOEVP is a parameter which adapts the snow evaporation (sublimation) equation to the field

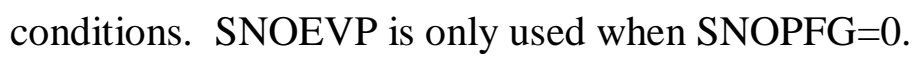

CCFACT is a parameter which adapts the snow condensation/convection melt equation to the field conditions. SNOEVP is only used when $\mathrm{SNOPFG}=0$.

MWATER is the maximum water content of the snowpack in depth of water per depth of water.

MGMELT is the maximum rate of snowmelt by ground heat in depth of water per day. MGMELT is the value that is applied when the pack temperature is at the freezing point. 
Table B.9. HSPF parameters for simulation of snow (SNOW), subroutine named "SNOWPARM2" used in this study for Clear Fork Watershed at Whitesville, WV

PERLND: SNOW-PARM2

\begin{tabular}{|c|c|c|c|c|c|c|c|}
\hline PERLND Number & Landuse/Land Cover & RDCSN & TSNOW & SNOEVP & CCFACT & MWATER & MGMELT \\
\hline & & dimensionless & $\left({ }^{\circ} \mathrm{F}\right)$ & dimensionless & dimensionless & dimensionless & (in/day) \\
\hline 101 & Urban/Developed & 0.15 & 32 & 0.1 & 1 & 0.03 & 0.01 \\
\hline 102 & Agricultural Land & 0.15 & 32 & 0.1 & 1 & 0.03 & 0.01 \\
\hline 103 & Forest Land & 0.15 & 32 & 0.1 & 1 & 0.03 & 0.01 \\
\hline 104 & Wetland/Water & 0.15 & 32 & 0.1 & 1 & 0.03 & 0.01 \\
\hline 105 & Barren/Mined Land & 0.15 & 32 & 0.1 & 1 & 0.03 & 0.01 \\
\hline Parameter Description & & $\begin{array}{c}\text { the density of cold, } \\
\text { new snow relative } \\
\text { to water }\end{array}$ & $\begin{array}{l}\text { air temperature } \\
\text { below which } \\
\text { precipitation will } \\
\text { be snow under } \\
\text { saturated } \\
\text { conditions }\end{array}$ & $\begin{array}{c}\text { parameter which } \\
\text { adapts the snow } \\
\text { evaporation } \\
\text { (sublimation) } \\
\text { equation to the } \\
\text { field conditions }\end{array}$ & $\begin{array}{l}\text { parameter which adapts } \\
\text { the snow } \\
\text { condensation/convection } \\
\text { melt equation to the field } \\
\text { conditions }\end{array}$ & $\begin{array}{c}\text { maximum water } \\
\text { content of the } \\
\text { snowpack in depth } \\
\text { of water per depth of } \\
\text { water }\end{array}$ & $\begin{array}{c}\text { maximum rate of } \\
\text { snowmelt by ground } \\
\text { heat in depth of water } \\
\text { per day }\end{array}$ \\
\hline
\end{tabular}

\section{References}

Atkins, J.T., J.B. Wiley, and K.S. Paybins, 2005. Calibration parameters used to simulate streamflow from application of the Hydrologic Simulation Program-FORTRAN model (HSPF) to mountainous basins containing coal mines in West Virginia. USGS Scientific Investigations Report, 2005-5099.

HSPF Version 12.2 User's Manual; prepared by AQUA TERRA Consultants of Mountain View, CA under sponsorship of the EPA under Contract No. 68-C-01-037 


\section{Appendix C: HSPF Calibration Trials}

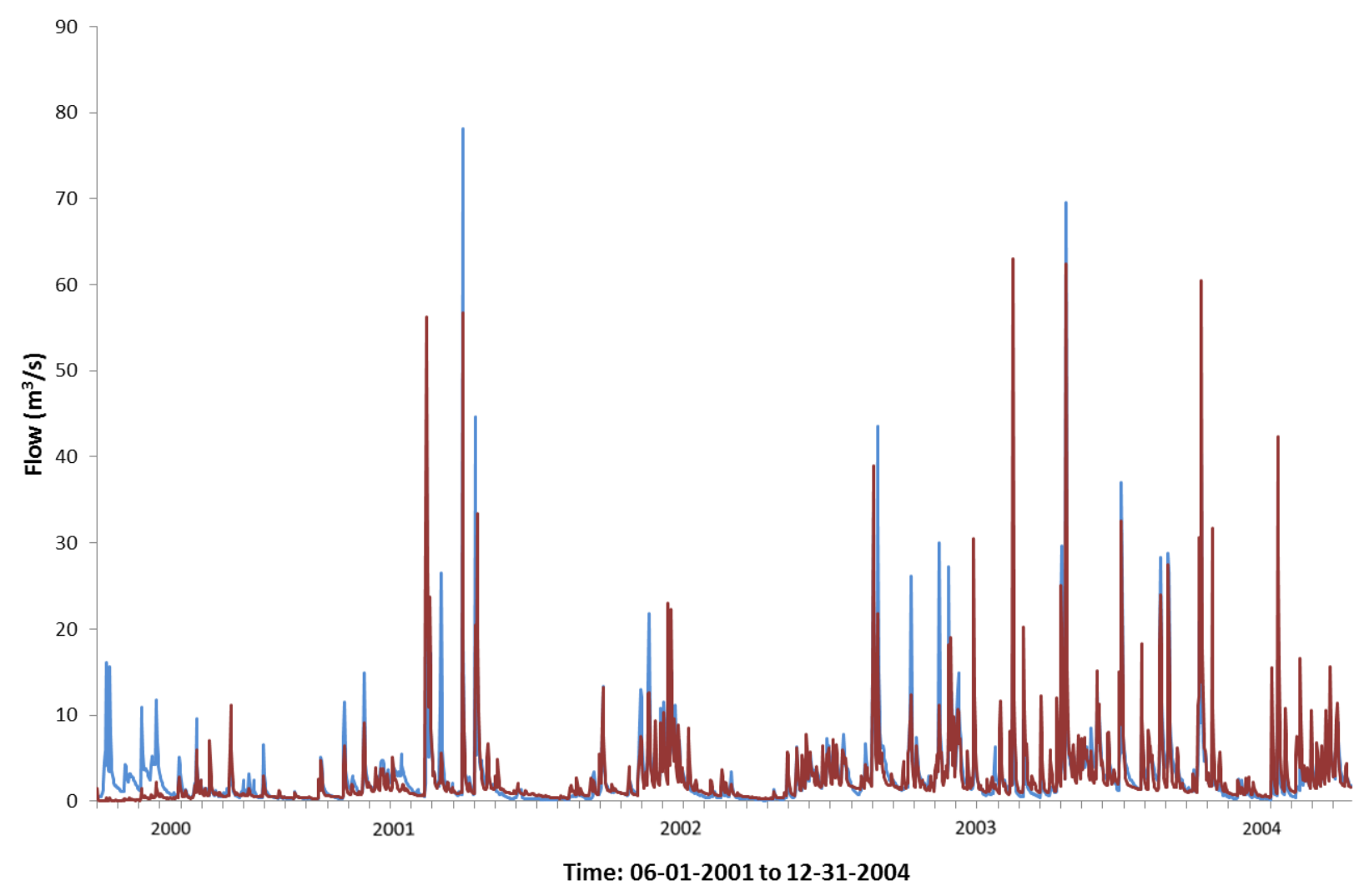

Figure C.1. Trial 2 model run observed and modeled daily flow comparison (modeled flow in red and observed flow in blue)

Table C.1. Model run results for calibration trial 2

\begin{tabular}{lcc}
\hline \multicolumn{1}{c}{ Calibration Criteria } & Limit or Range & $\begin{array}{c}\text { Model } \\
\text { Results }\end{array}$ \\
\hline Total Flow Error & $\pm 10 \%$ & $-0.40 \%$ \\
Lowest 50\% Flow Error & $\pm 10 \%$ & $-5.41 \%$ \\
Highest 10\% Flow Error & $\pm 15 \%$ & $35.81 \%$ \\
Mean Storm Volume Error & $\pm 15 \%$ & $14.36 \%$ \\
Mean Storm Peak Flow Error & $\pm 15 \%$ & $-37.12 \%$ \\
Overall Water Balance Error & $-1.3-32.9$ & $*$ \\
Mean Yearly Water Balance Error & $-2.1-27.8$ & $*$ \\
Mean Monthly Water Balance Error & $0.7-83.9$ & $*$ \\
$*$ Water Balance not calculated due to other error allowances not met
\end{tabular}




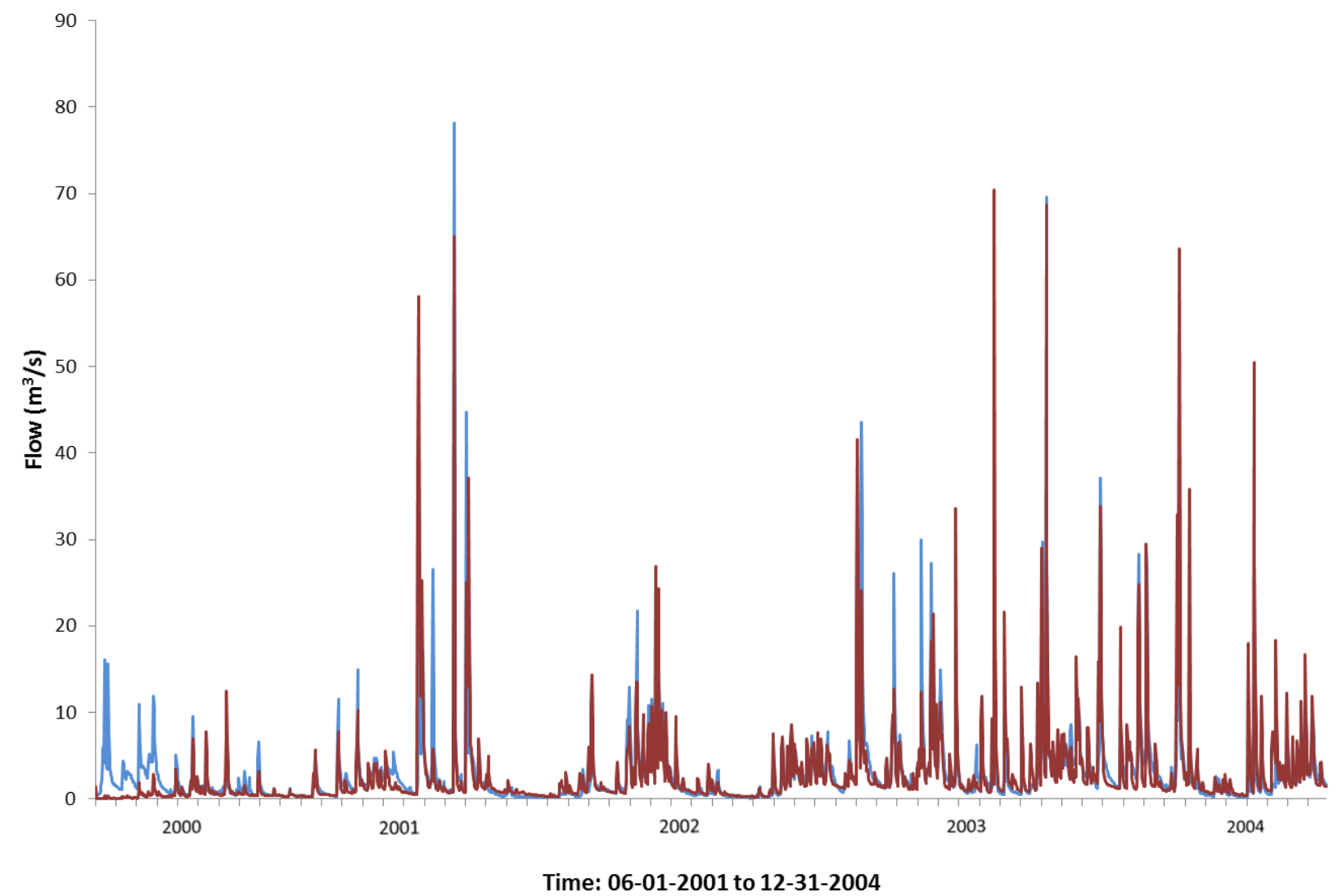

Figure C.2. Trial 3 model run observed and modeled daily flow comparison (modeled flow in red and observed flow in blue)

Table C.2. Model run results for calibration trial 3

\begin{tabular}{lcc}
\hline \multicolumn{1}{c}{ Calibration Criteria } & Limit or Range & $\begin{array}{c}\text { Model } \\
\text { Results }\end{array}$ \\
\hline Total Flow Error & $\pm 10 \%$ & $0.60 \%$ \\
Lowest 50\% Flow Error & $\pm 10 \%$ & $-24.36 \%$ \\
Highest 10\% Flow Error & $\pm 15 \%$ & $39.88 \%$ \\
Mean Storm Volume Error & $\pm 15 \%$ & $15.21 \%$ \\
Mean Storm Peak Flow Error & $\pm 15 \%$ & $-41.66 \%$ \\
Overall Water Balance Error & $-1.3-32.9$ & $*$ \\
Mean Yearly Water Balance Error & $-2.1-27.8$ & $*$ \\
Mean Monthly Water Balance Error & $0.7-83.9$ & $*$ \\
$*$ Water Balance not calculated due to other error allowances not met
\end{tabular}




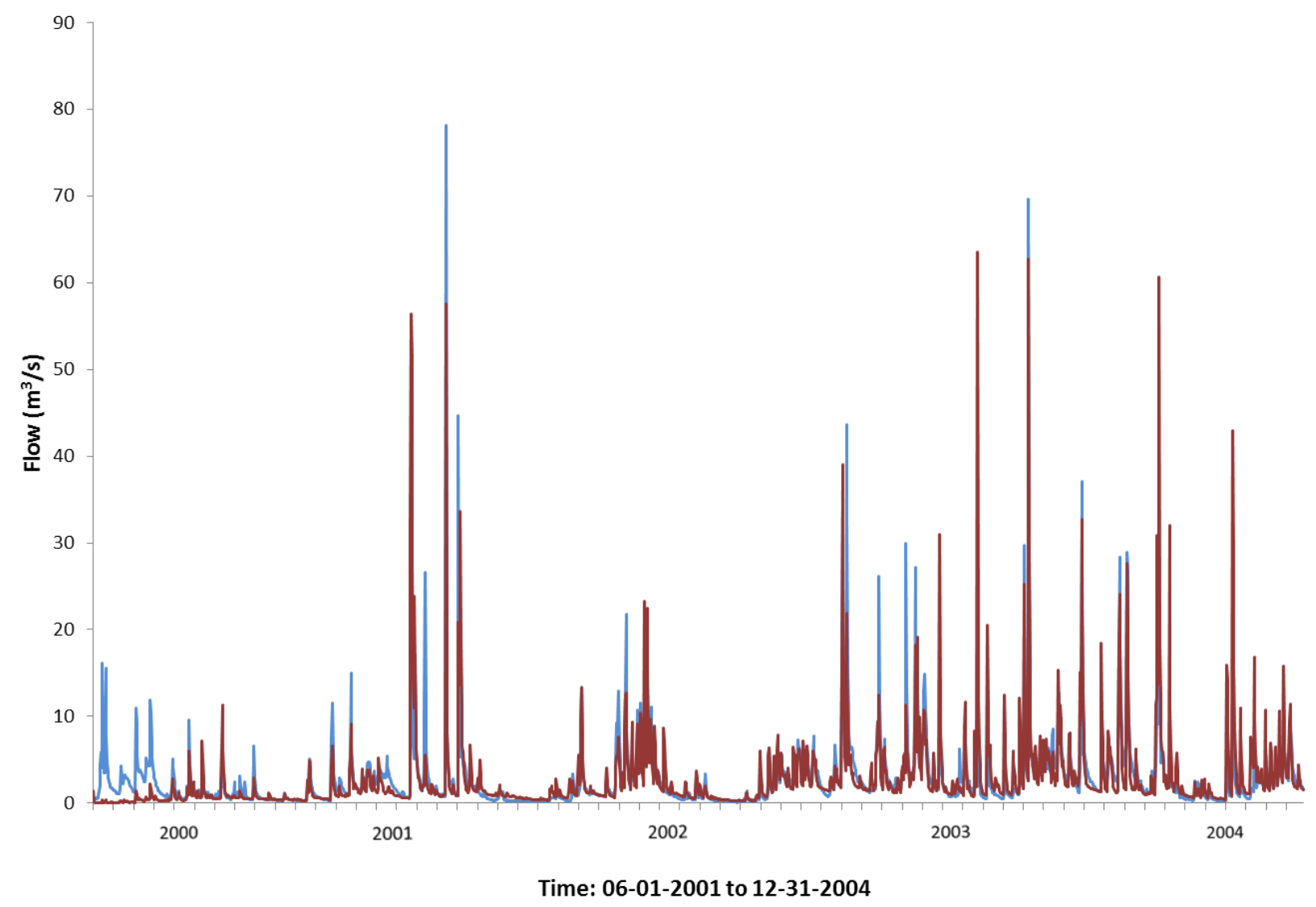

Figure C.3. Trial 4 model run observed and modeled daily flow comparison (modeled flow in red and observed flow in blue)

Table C.3. Model run results for calibration trial 4

\begin{tabular}{lcc}
\hline \multicolumn{1}{c}{ Calibration Criteria } & Limit or Range & $\begin{array}{c}\text { Model } \\
\text { Results }\end{array}$ \\
\hline Total Flow Error & $\pm 10 \%$ & $3.02 \%$ \\
Lowest 50\% Flow Error & $\pm 10 \%$ & $-11.39 \%$ \\
Highest 10\% Flow Error & $\pm 15 \%$ & $41.07 \%$ \\
Mean Storm Volume Error & $\pm 15 \%$ & $14.98 \%$ \\
Mean Storm Peak Flow Error & $\pm 15 \%$ & $-41.44 \%$ \\
Overall Water Balance Error & $-1.3-32.9$ & $*$ \\
Mean Yearly Water Balance Error & $-2.1-27.8$ & $*$ \\
Mean Monthly Water Balance Error & $0.7-83.9$ & $*$ \\
$*$ Water Balance not calculated due to other error allowances not met
\end{tabular}




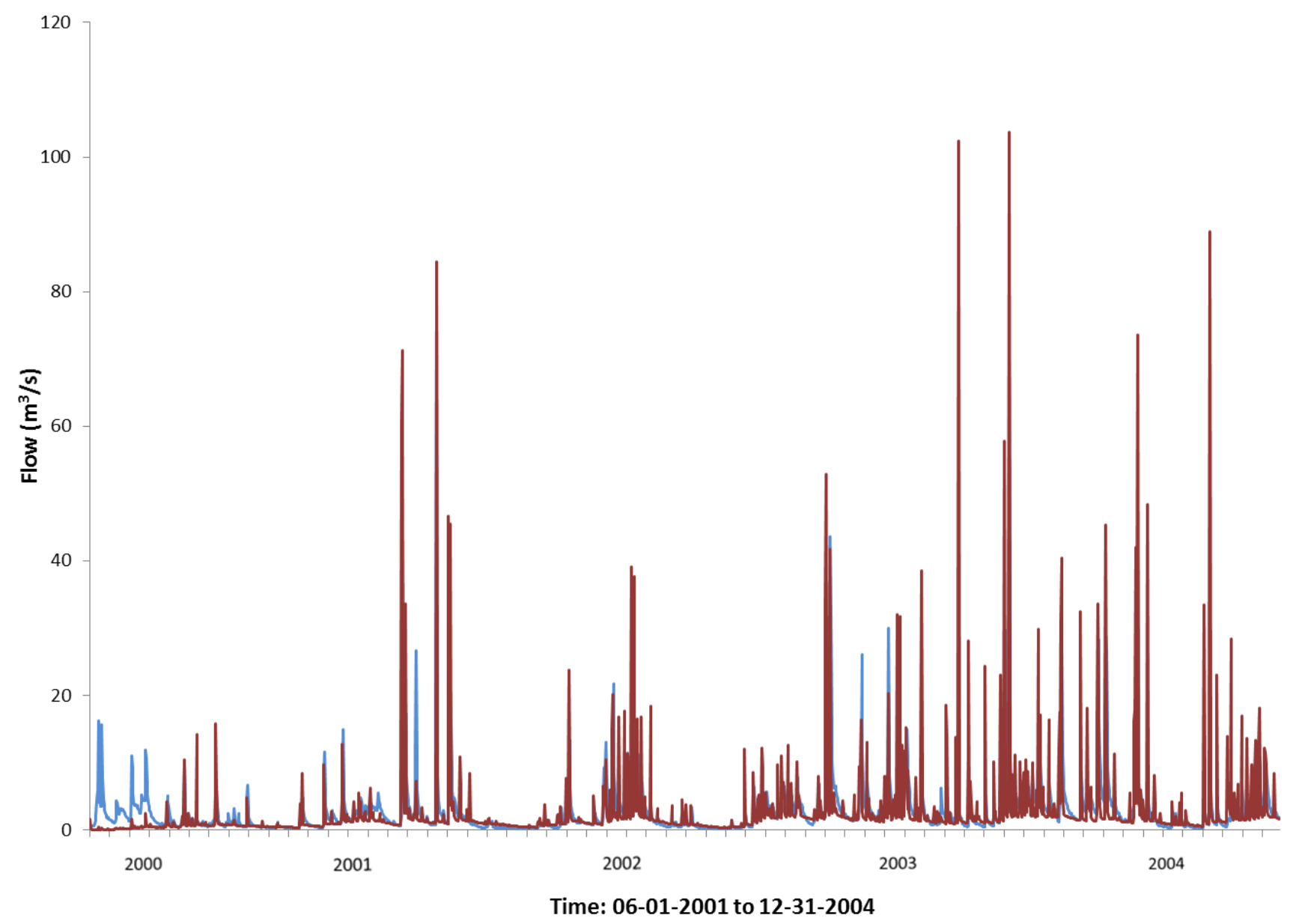

Figure C.4. Trial 5 model run observed and modeled daily flow comparison (modeled flow in red and observed flow in blue)

Table C.4. Model run results for calibration trial 5

\begin{tabular}{lcc}
\hline \multicolumn{1}{c}{ Calibration Criteria } & Limit or Range & $\begin{array}{c}\text { Model } \\
\text { Results }\end{array}$ \\
\hline Total Flow Error & $\pm 10 \%$ & $0.63 \%$ \\
Lowest 50\% Flow Error & $\pm 10 \%$ & $-6.09 \%$ \\
Highest 10\% Flow Error & $\pm 15 \%$ & $38.32 \%$ \\
Mean Storm Volume Error & $\pm 15 \%$ & $13.65 \%$ \\
Mean Storm Peak Flow Error & $\pm 15 \%$ & $-38.31 \%$ \\
Overall Water Balance Error & $-1.3-32.9$ & $*$ \\
Mean Yearly Water Balance Error & $-2.1-27.8$ & $*$ \\
Mean Monthly Water Balance Error & $0.7-83.9$ & $*$ \\
$*$ Water Balance not calculated due to other error allowances not met
\end{tabular}




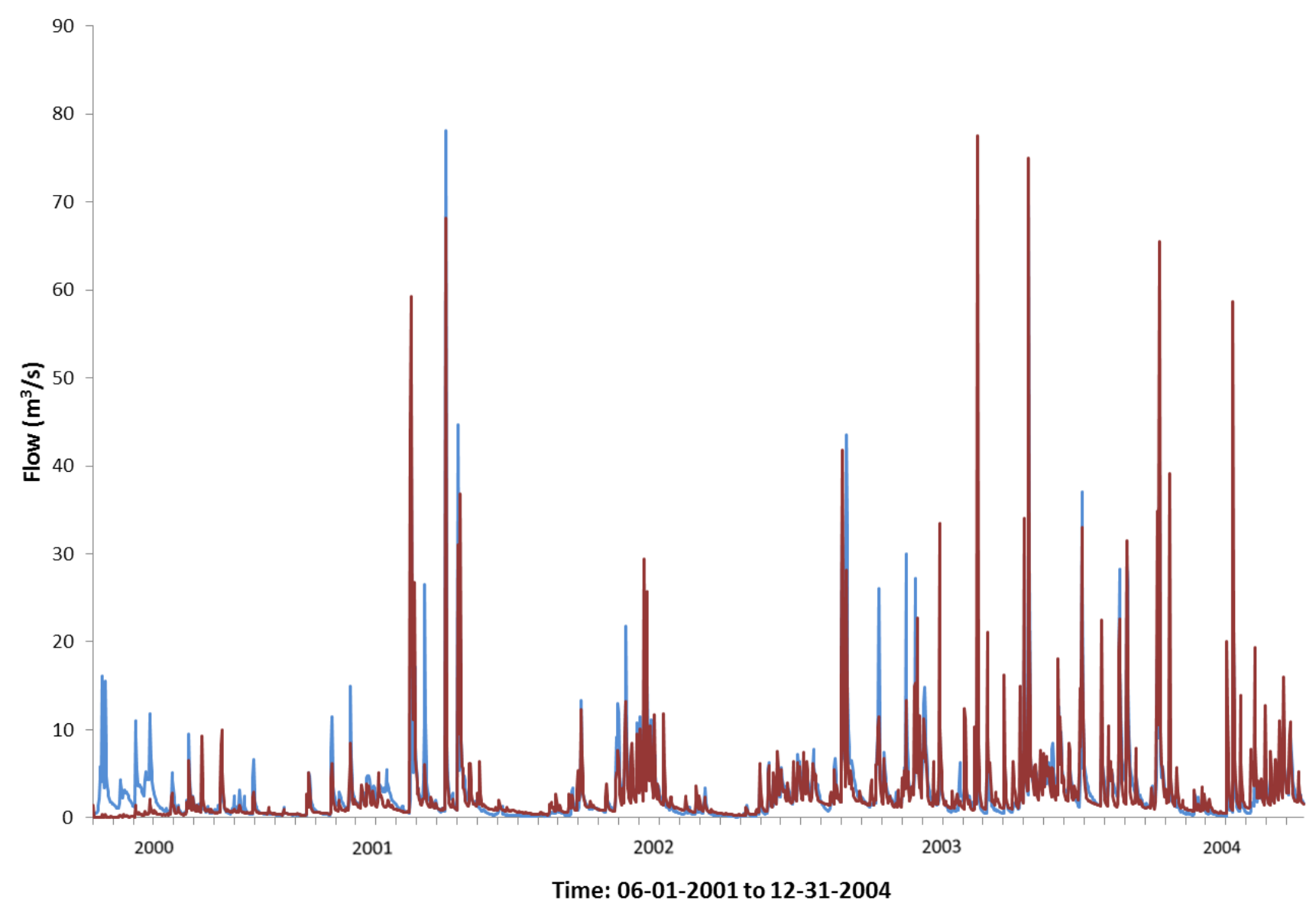

Figure C.5. Trial 6 model run observed and modeled daily flow comparison (modeled flow in red and observed flow in blue)

Table C.5. Model run results for calibration trial 6

\begin{tabular}{lcc}
\hline \multicolumn{1}{c}{ Calibration Criteria } & Limit or Range & $\begin{array}{c}\text { Model } \\
\text { Results }\end{array}$ \\
\hline Total Flow Error & $\pm 10 \%$ & $1.05 \%$ \\
Lowest 50\% Flow Error & $\pm 10 \%$ & $0.57 \%$ \\
Highest 10\% Flow Error & $\pm 15 \%$ & $19.36 \%$ \\
Mean Storm Volume Error & $\pm 15 \%$ & $11.86 \%$ \\
Mean Storm Peak Flow Error & $\pm 15 \%$ & $-23.55 \%$ \\
Overall Water Balance Error & $-1.3-32.9$ & $*$ \\
Mean Yearly Water Balance Error & $-2.1-27.8$ & $*$ \\
Mean Monthly Water Balance Error & $0.7-83.9$ & $*$ \\
\hline
\end{tabular}

* Water Balance not calculated due to other error allowances not met 


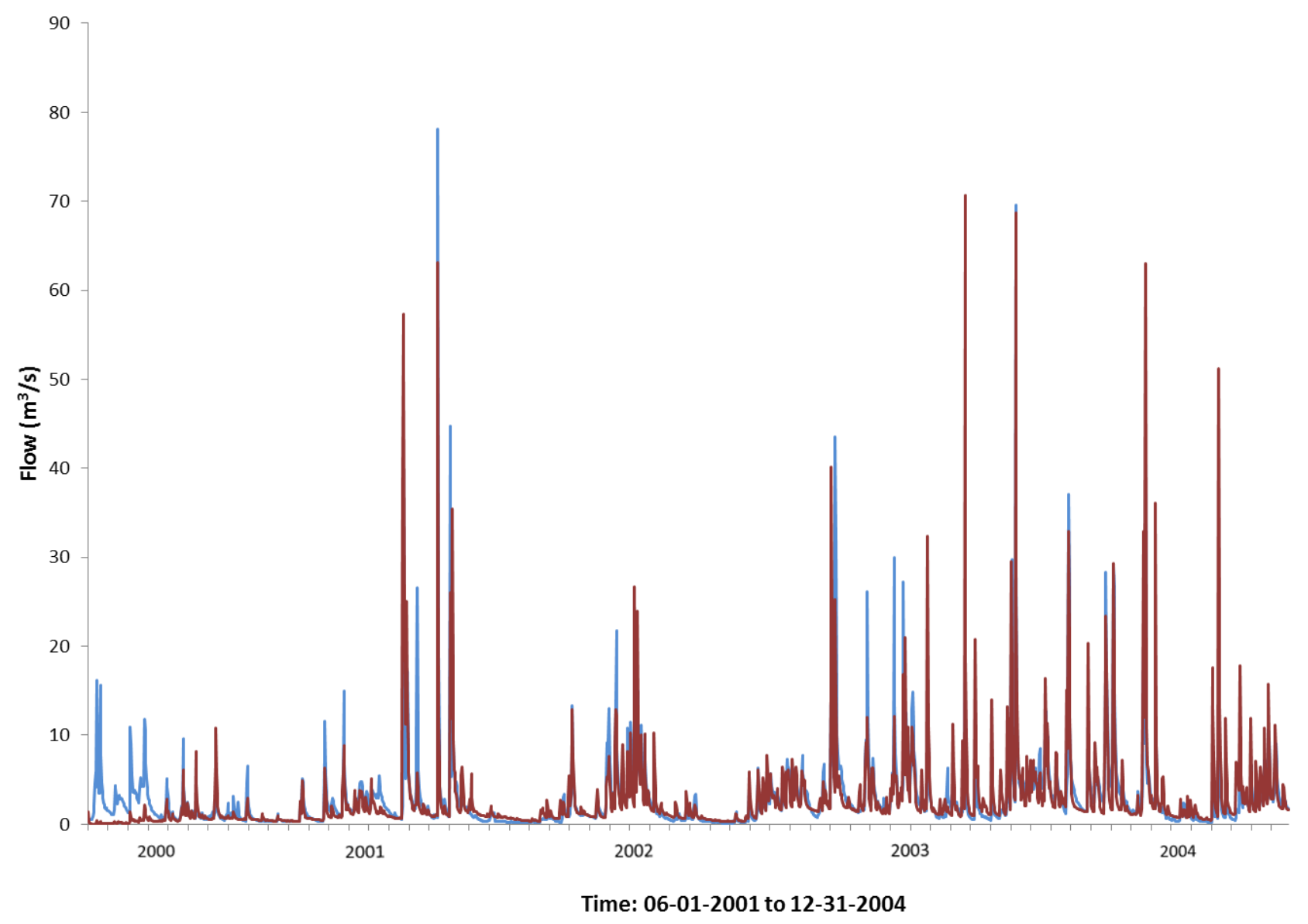

Figure C.6. Trial 7 model run observed and modeled daily flow comparison (modeled flow in red and observed flow in blue)

Table C.6. Model run results for calibration trial 7

\begin{tabular}{lcc}
\hline \multicolumn{1}{c}{ Calibration Criteria } & Limit or Range & $\begin{array}{c}\text { Model } \\
\text { Results }\end{array}$ \\
\hline Total Flow Error & $\pm 10 \%$ & $1.14 \%$ \\
Lowest 50\% Flow Error & $\pm 10 \%$ & $0.71 \%$ \\
Highest 10\% Flow Error & $\pm 15 \%$ & $13.24 \%$ \\
Mean Storm Volume Error & $\pm 15 \%$ & $10.53 \%$ \\
Mean Storm Peak Flow Error & $\pm 15 \%$ & $-20.09 \%$ \\
Overall Water Balance Error & $-1.3-32.9$ & $*$ \\
Mean Yearly Water Balance Error & $-2.1-27.8$ & $*$ \\
Mean Monthly Water Balance Error & $0.7-83.9$ & $*$ \\
* Water Balance not calculated due to other error allowances not met
\end{tabular}




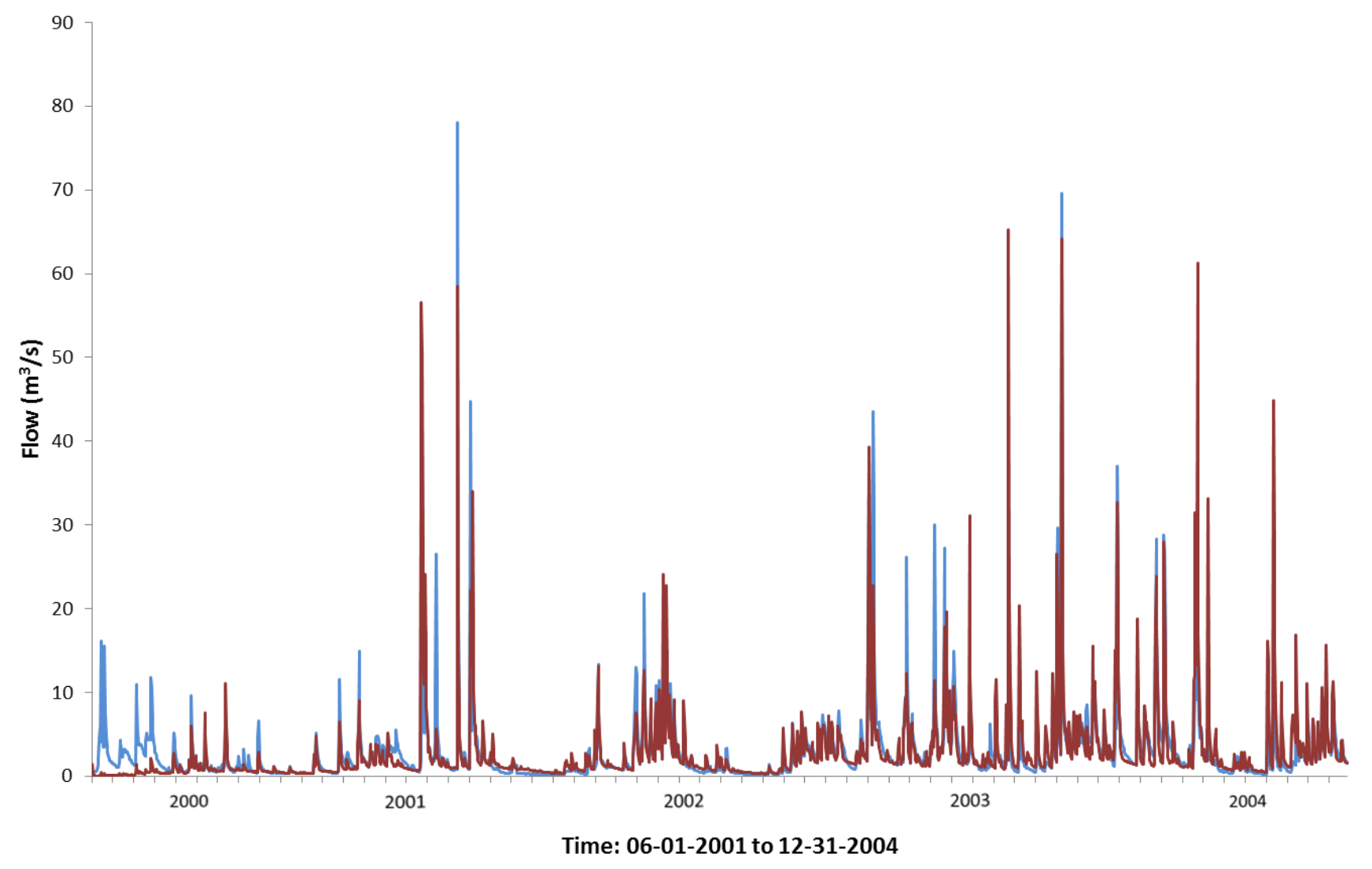

Figure C.7. Trial 8 model run observed and modeled daily flow comparison (modeled flow in red and observed flow in blue)

Table C.7. Model run results for calibration trial 8

\begin{tabular}{lcc}
\hline \multicolumn{1}{c}{ Calibration Criteria } & Limit or Range & $\begin{array}{c}\text { Model } \\
\text { Results }\end{array}$ \\
\hline Total Flow Error & $\pm 10 \%$ & $1.20 \%$ \\
Lowest 50\% Flow Error & $\pm 10 \%$ & $0.69 \%$ \\
Highest 10\% Flow Error & $\pm 15 \%$ & $8.98 \%$ \\
Mean Storm Volume Error & $\pm 15 \%$ & $7.35 \%$ \\
Mean Storm Peak Flow Error & $\pm 15 \%$ & $-17.27 \%$ \\
Overall Water Balance Error & $-1.3-32.9$ & $*$ \\
Mean Yearly Water Balance Error & $-2.1-27.8$ & $*$ \\
Mean Monthly Water Balance Error & $0.7-83.9$ & $*$ \\
$*$ Water Balance not calculated due to other error allowances not met
\end{tabular}




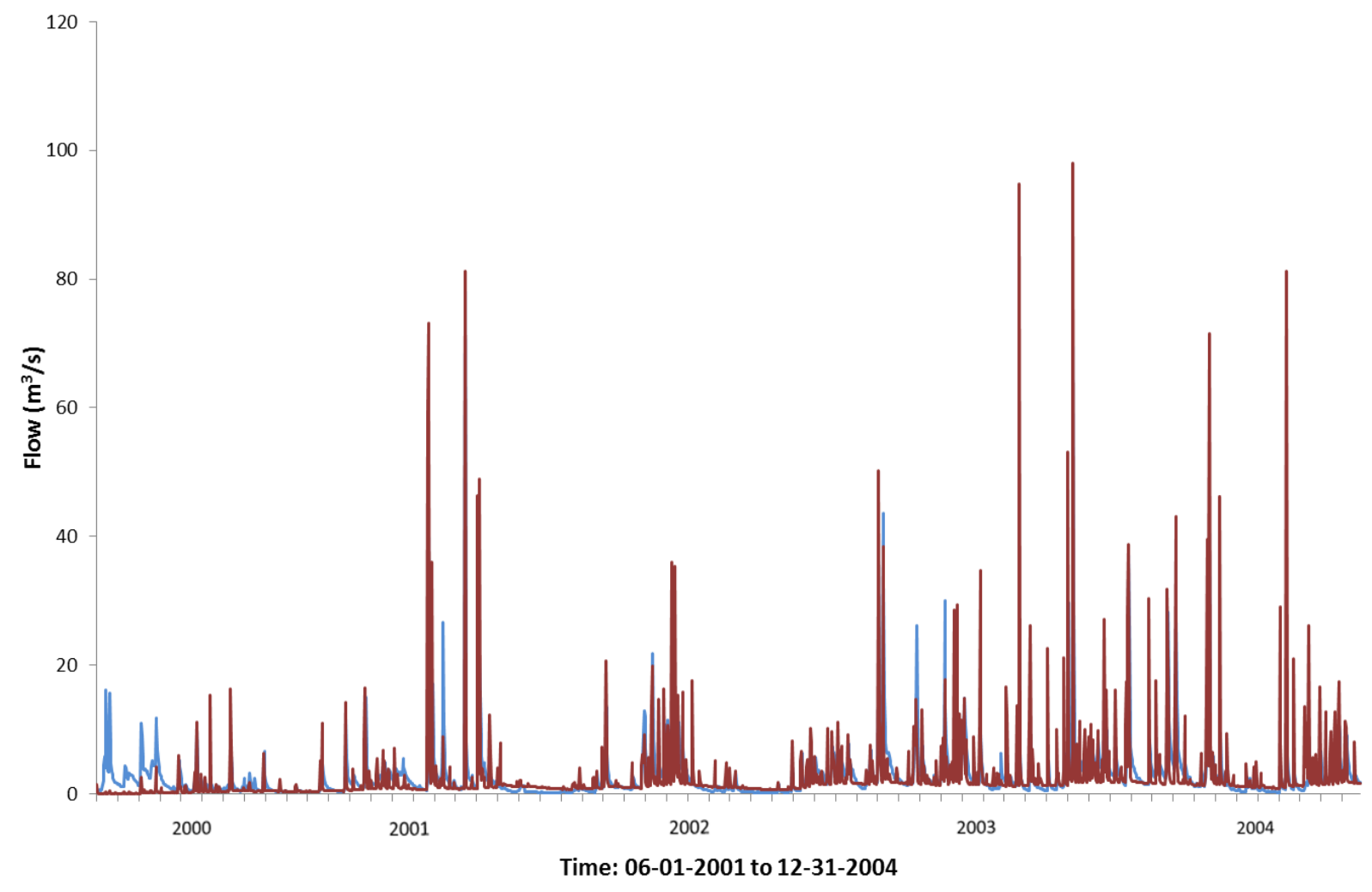

Figure C.8. Trial 9 model run observed and modeled daily flow comparison (modeled flow in red and observed flow in blue)

Table C.8. Model run results for calibration trial 9

\begin{tabular}{lcc}
\hline \multicolumn{1}{c}{ Calibration Criteria } & Limit or Range & $\begin{array}{c}\text { Model } \\
\text { Results }\end{array}$ \\
\hline Total Flow Error & $\pm 10 \%$ & $7.73 \%$ \\
Lowest 50\% Flow Error & $\pm 10 \%$ & $0.49 \%$ \\
Highest 10\% Flow Error & $\pm 15 \%$ & $11.15 \%$ \\
Mean Storm Volume Error & $\pm 15 \%$ & $5.79 \%$ \\
Mean Storm Peak Flow Error & $\pm 15 \%$ & $-16.05 \%$ \\
Overall Water Balance Error & $-1.3-32.9$ & $*$ \\
Mean Yearly Water Balance Error & $-2.1-27.8$ & $*$ \\
Mean Monthly Water Balance Error & $0.7-83.9$ & $*$ \\
$*$ Water Balance not calculated due to other error allowances not met
\end{tabular}




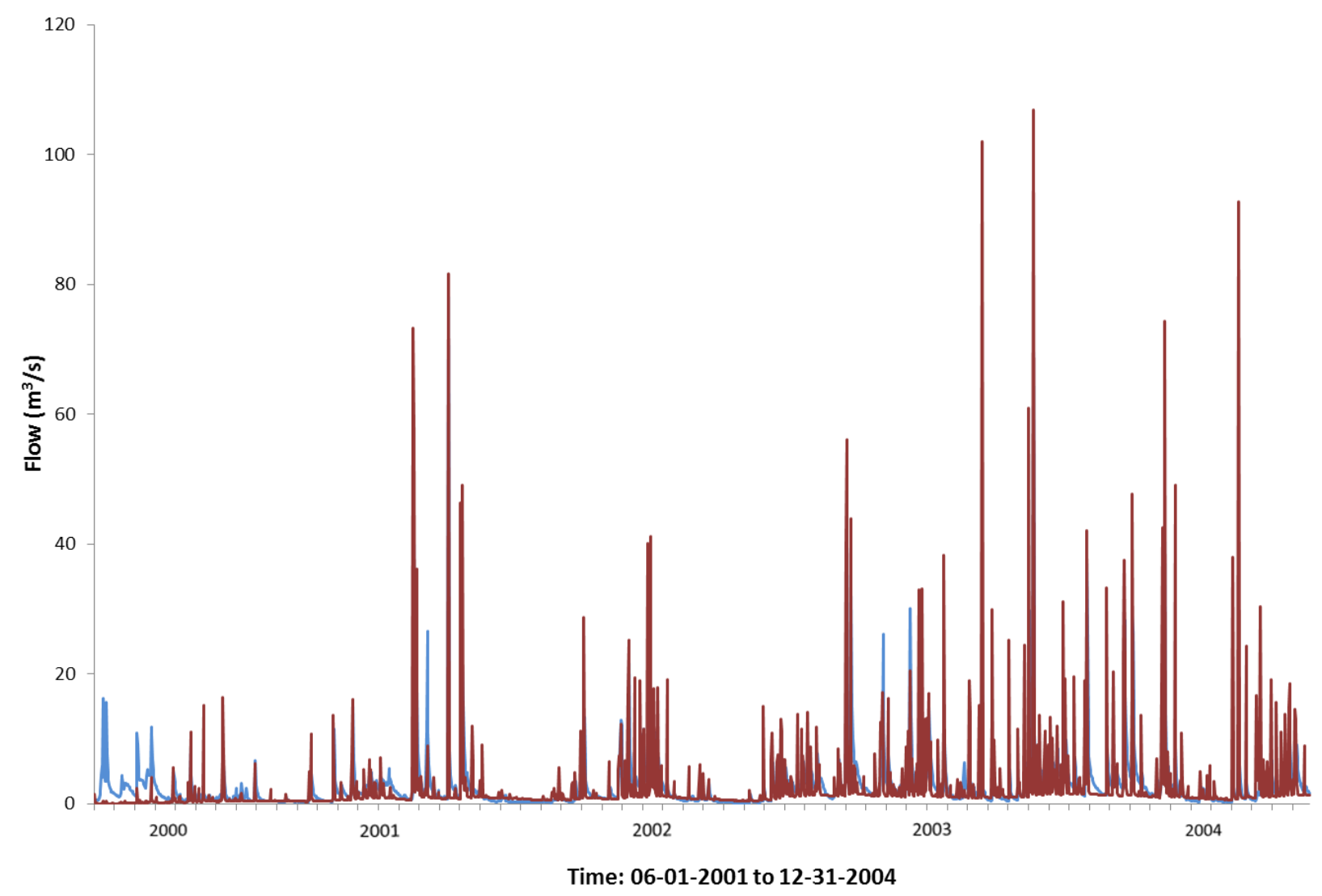

Figure C.9. Trial 10 model run observed and modeled daily flow comparison (modeled flow in red and observed flow in blue)

Table C.9. Model run results for calibration trial 10

\begin{tabular}{lcc}
\hline \multicolumn{1}{c}{ Calibration Criteria } & Limit or Range & $\begin{array}{c}\text { Model } \\
\text { Results }\end{array}$ \\
\hline Total Flow Error & $\pm 10 \%$ & $8.10 \%$ \\
Lowest 50\% Flow Error & $\pm 10 \%$ & $9.98 \%$ \\
Highest 10\% Flow Error & $\pm 15 \%$ & $4.25 \%$ \\
Mean Storm Volume Error & $\pm 15 \%$ & $5.65 \%$ \\
Mean Storm Peak Flow Error & $\pm 15 \%$ & $-1.26 \%$ \\
Overall Water Balance Error & $-1.3-32.9$ & $*$ \\
Mean Yearly Water Balance Error & $-2.1-27.8$ & $*$ \\
Mean Monthly Water Balance Error & $0.7-83.9$ & $*$ \\
$*$ Water Balance not calculated due to other error allowances not met
\end{tabular}




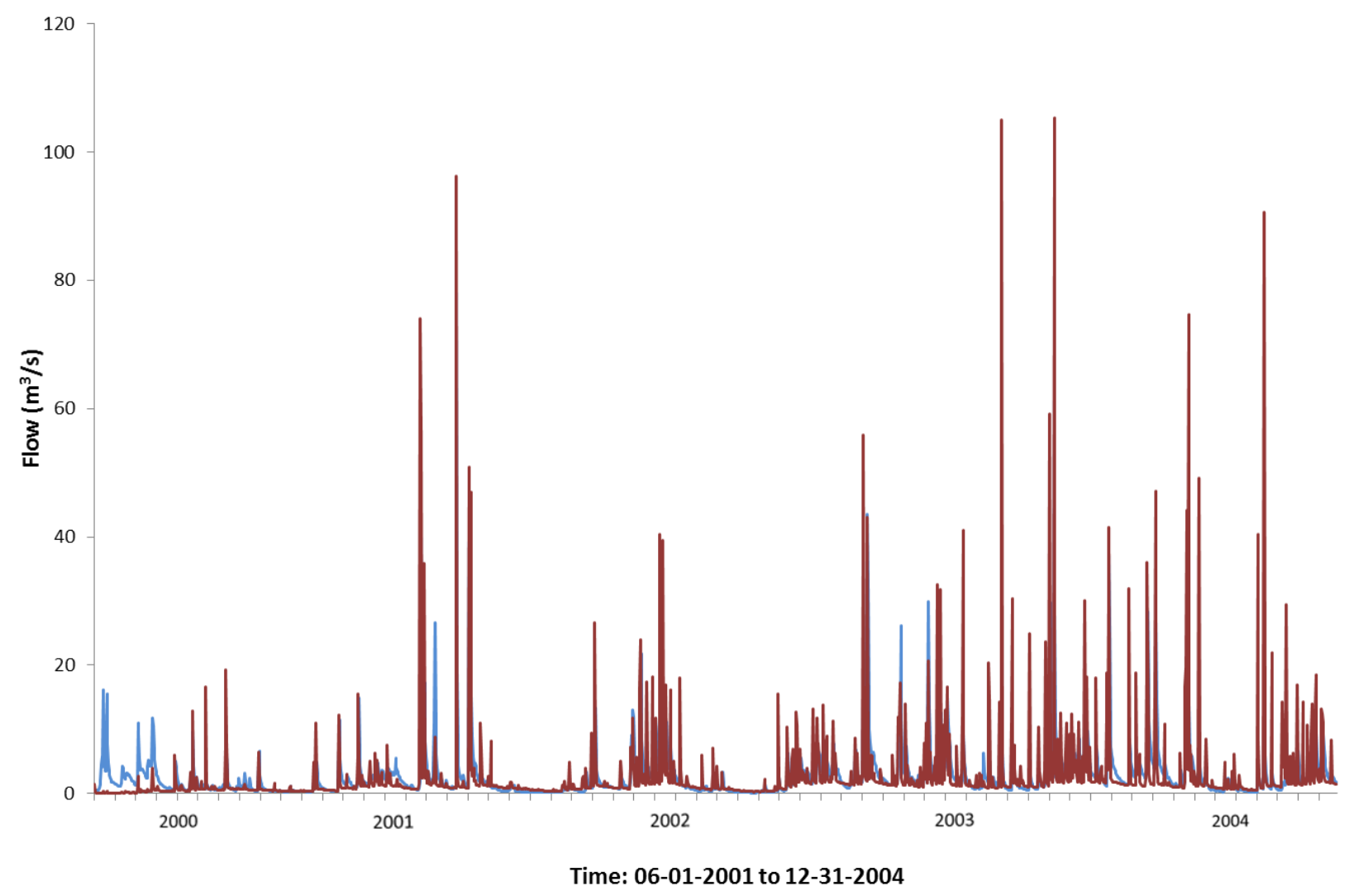

Figure C.10. Trial 11 model run observed and modeled daily flow comparison (modeled flow in red and observed flow in blue)

Table C.10. Model run results for calibration trial 11

\begin{tabular}{lcc}
\hline \multicolumn{1}{c}{ Calibration Criteria } & Limit or Range & $\begin{array}{c}\text { Model } \\
\text { Results }\end{array}$ \\
\hline Total Flow Error & $\pm 10 \%$ & $7.40 \%$ \\
Lowest 50\% Flow Error & $\pm 10 \%$ & $9.62 \%$ \\
Highest 10\% Flow Error & $\pm 15 \%$ & $3.84 \%$ \\
Mean Storm Volume Error & $\pm 15 \%$ & $5.17 \%$ \\
Mean Storm Peak Flow Error & $\pm 15 \%$ & $-0.98 \%$ \\
Overall Water Balance Error & $-1.3-32.9$ & $*$ \\
Mean Yearly Water Balance Error & $-2.1-27.8$ & $*$ \\
Mean Monthly Water Balance Error & $0.7-83.9$ & $*$ \\
\hline
\end{tabular}

* Water Balance not calculated due to other error allowances not met 